INSTITUTO DE PESQUISAS ENERGÉTICAS E NUCLEARES

Autarquia associada à Universidade de São Paulo

CÁLCULO DE VIABILIDADE ECONÔMICA DE FONTES ALTERNATIVAS DE ENERGIA CONSIDERANDO SEUS CUSTOS AMBIENTAIS PARA PEQUENAS COMUNIDADES DA REGIÃO NORDESTE BRASILEIRA

LUIZA CHOURKALO STECHER

Dissertação apresentada como parte dos requisitos para obtenção do Grau de Mestre em Ciências na Área de Tecnologia Nuclear- Reatores.

Orientadora:

Dra. Gaianê Sabundjian 
Dedico este trabalho aos meus pais, José e Tatiana. 


\section{AGRADECIMENTOS}

Agradeço aos meus pais, José e Tatiana, pelo amor a mim dedicado, pela confiança e pelo apoio incondicional em todos os momentos da minha vida.

Á minha querida orientadora, Dra. Gaianê Sabundjian, por sua ajuda na concretização de um sonho, por sua orientação dedicada e atenciosa, pela confiança, paciência, compreensão e ensinamentos durante o desenvolvimento deste trabalho.

À Prof. Dra. Martha Marques Ferreira Vieira, por seu apoio.

Ao Prof. Dr. Roberto Zilles e à Prof. Dra. Suani Teixeira Coelho, do Instituto de Energia e Meio Ambiente da USP, e à Prof. Dra. Eliane Aparecida Faria Amaral Fadigas, da Escola Politécnica da USP, por suas importantes contribuições para o desenvolvimento dessa pesquisa

A todos os amigos do Centro de Engenharia Nuclear (CEN) que estiveram ao meu lado durante o desenvolvimento desse trabalho, pelo companheirismo, apoio, incentivo e por tantos momentos de alegria.

Aos amigos do Instituto de Pesquisas Energéticas e Nucleares (IPEN).

Aos amigos que me acompanharam e apoiaram em tantos momentos durante o desenvolvimento desse trabalho.

Ao Instituto de Pesquisas Energéticas e Nucleares e à Universidade de São Paulo.

À Comissão Nacional de Energia Nuclear (CNEN) pelo apoio financeiro.

Enfim, a todos os que, de alguma forma, contribuíram para a realização desse trabalho, meus sinceros agradecimentos. 


\title{
CÁLCULO DE VIABILIDADE ECONÔMICA DE FONTES ALTERNATIVAS DE ENERGIA CONSIDERANDO SEUS CUSTOS AMBIENTAIS PARA PEQUENAS COMUNIDADES DA REGIÃO NORDESTE BRASILEIRA
}

\author{
Luiza Chourkalo Stecher
}

\begin{abstract}
RESUMO
A atual problemática ambiental provocada pela atividade humana tem ganhado destaque na sociedade, à medida que se busca o desenvolvimento mundial. Um fator de extrema relevância neste cenário é a produção de energia elétrica, responsável por uma grande parcela das emissões causadoras do efeito estufa. Por conta disso, é preciso pensar em um desenvolvimento sustentável, com fontes alternativas de energia atrativas para esse objetivo, principalmente em localidades não abastecidas pela rede convencional de eletricidade, como é o caso de muitas comunidades da região nordeste brasileira. Assim, esse trabalho tem por objetivos calcular o custo ambiental, na fase de geração de eletricidade, para as fontes alternativas de energia solar, eólica e biomassa e estimar a viabilidade econômica dessas fontes em pequenas comunidades da região Nordeste do Brasil, considerando os custos evitados. É preciso identificar as externalidades e valorá-las de forma adequada para que os custos ou benefícios possam ser internalizados e reflitam de forma correta a viabilidade ou inviabilidade econômica dessas fontes. Para os objetivos propostos, adotou-se o método dos custos evitados para o cálculo das externalidades. Essa variável foi incluída no equacionamento desenvolvido para todas as fontes de energia alternativas consideradas. Foram feitos os cálculos de viabilidade econômica, considerando as novas configurações adotadas, sendo que 0 novo equacionamento foi reprogramado no Programa de Cálculo de Custos de Energias Alternativas, Solar, Eólica e Biomassa (PEASEB). Os resultados demonstraram que a fonte mais viável e amplamente aplicável em pequenas comunidades da região nordeste brasileira é a energia solar fotovoltaica em sistemas isolados.
\end{abstract}




\title{
CALCULATION OF ECONOMIC VIABILITY OF ALTERNATIVE ENERGY SOURCES CONSIDERING ITS ENVIRONMENTAL COSTS FOR SMALL COMMUNITIES OF NORTHEAST BRAZIL
}

\author{
Luiza Chourkalo Stecher
}

\begin{abstract}
There has been an increasing concern about current environmental issues caused by human activity, as the world searches for development. The production of electricity is an extremely relevant factor in this scenario since it is responsible for a large portion of the emissions that cause the greenhouse effect. Due to this fact, a sustainable development with alternative energy sources, which are attractive for such purpose, must be proposed, especially in places that are not supplied by the conventional electricity grid such as many communities in the Northeast Brazil. This work aims to calculate the environmental cost for the alternative sources of energy - solar, wind and biomass - during electricity generation, and to estimate the economic feasibility of those sources in small communities of Northeast Brazil, considering the avoided costs. The externalities must be properly identified and valued so the costs or benefits can be internalized and reflect accurately the economic feasibility or infeasibility of those sources. For this, the method of avoided costs was adopted for the calculation of externalities. This variable was included in the equation developed for all considered alternative energy sources. The calculations of economic feasibility were performed taking the new configurations in consideration, and the new equation was reprogrammed in the Programa de Cálculo de Custos de Energias Alternativas, Solar, Eólica e Biomassa (PEASEB). The results demonstrated that the solar photovoltaic energy in isolated systems is the most feasible and broadly applicable source for small communities of Northeast Brazil.
\end{abstract}




\section{SUMÁRIO}

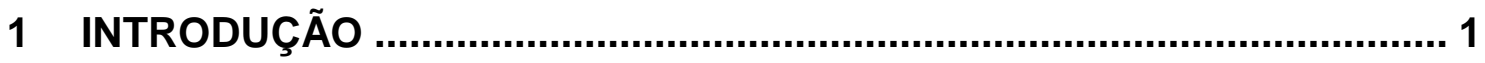

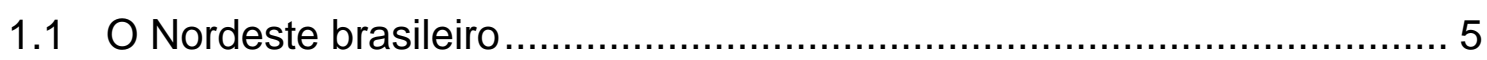

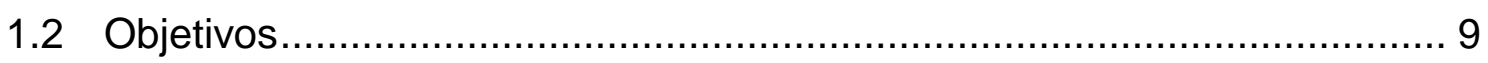

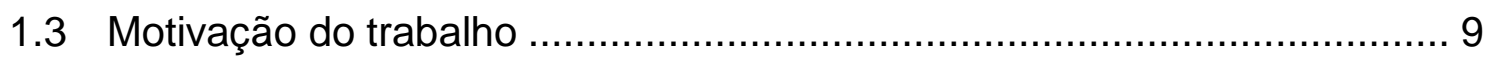

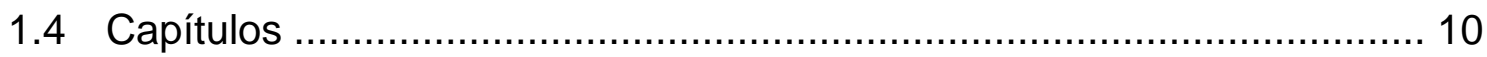

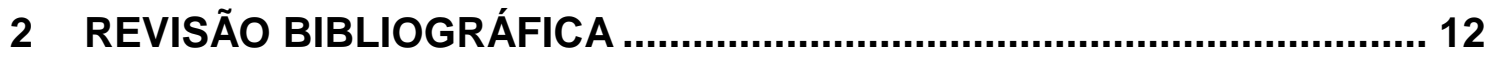

3 ECONOMIA E MEIO-AMBIENTE...................................................... 18

3.1 A economia e o meio ambiente: origens e o início dos debates .............. 18

3.2 Relação entre atividade econômica e meio ambiente ............................ 19

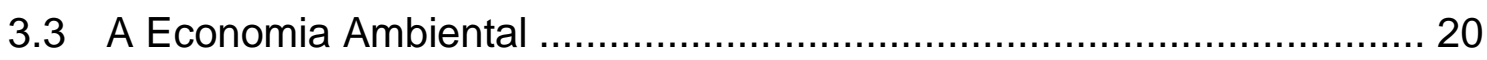

3.3.1 Classificação dos danos ambientais de acordo com a sua origem, fonte e extensão.

3.3.2 Fundamentos da Economia Ambiental ............................................. 22

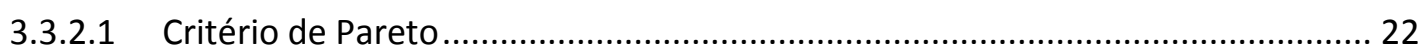

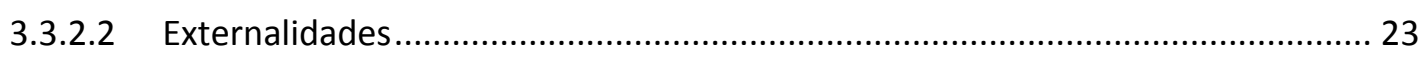

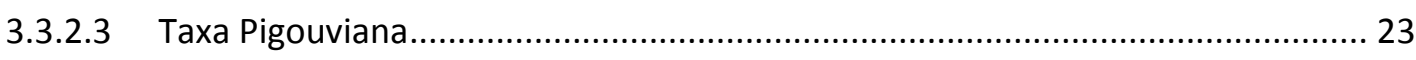

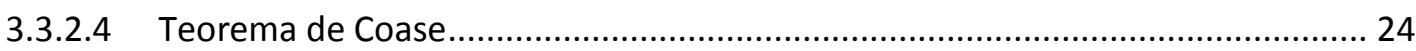

3.4 Os bens públicos ...................................................................... 25

3.5 A economia do bem-estar e sua ligação com o a Economia Ambiental .. 26

3.6 A importância da valoração ambiental ............................................... 26

4 METODOLOGIA PARA OS CÁLCULOS DOS CUSTOS AMBIENTAIS.. 29

4.1 A valoração econômica dos recursos ambientais (VERA) ...................... 29

4.2 Metodologia para a obtenção do VERA e dos custos ambientais das fontes

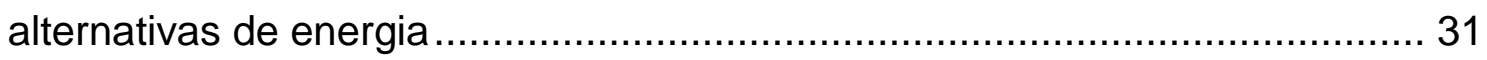

4.3 Análise das emissões de Gases de Efeito Estufa (GEE) ....................... 32

4.4 O mecanismo de desenvolvimento limpo (MDL) e sua contribuição para a análise dos custos ambientais .................................................................. 33

5 METODOLOGIA DE CÁLCULO DE VIABILIDADE ECONÔMICA PARA ENERGIA SOLAR FOTOVOLTAICA ....................................................... 36

5.1 Definições gerais para os sistemas .................................................. 36

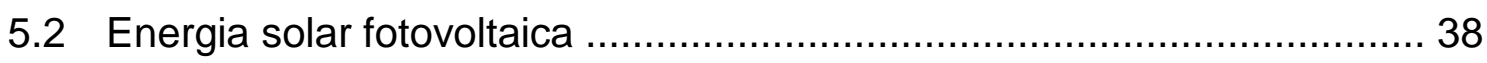




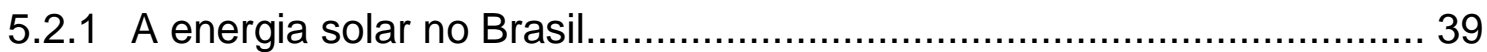

5.2.2 A energia solar no Nordeste brasileiro ........................................... 40

5.2.3 Viabilidade econômica da energia solar fotovoltaica considerando seus custos ambientais

5.2.3.1 Equações e cálculos para as minirredes............................................................. 41

5.2.3.2 Equações e cálculos para sistemas isolados ....................................................... 46

6 METODOLOGIA DE CÁLCULO DE VIABILIDADE ECONÔMICA PARA A

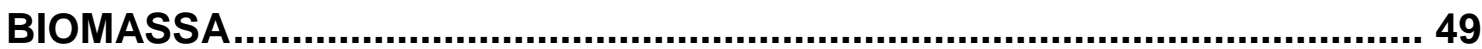

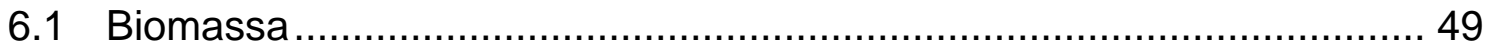

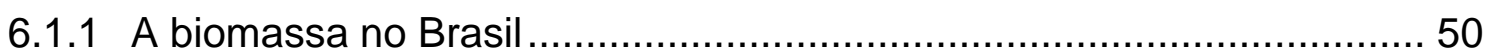

6.1.2 A biomassa no Nordeste do Brasil ................................................... 51

6.1.3 Viabilidade econômica da biomassa considerando seus custos ambientais 53

6.1.3.1 Cálculo da Viabilidade Econômica para Biomassa de Resíduos Agrícolas .......... 57

6.1.3.2 Cálculo de Viabilidade Econômica da Biomassa de Dendê.............................. 65

\section{METODOLOGIA DE CÁLCULO DE VIABILIDADE ECONÔMICA PARA A}

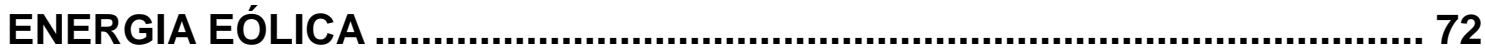

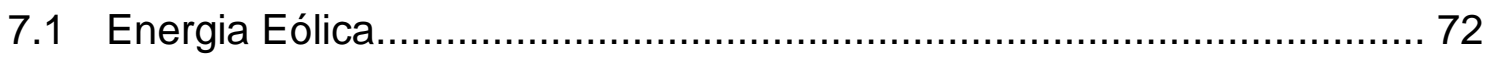

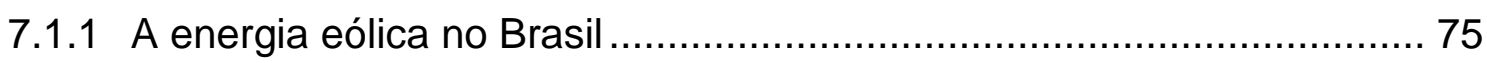

7.1.2 Viabilidade econômica da energia eólica considerando seus custos

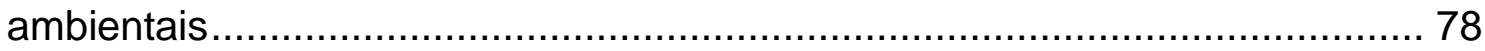

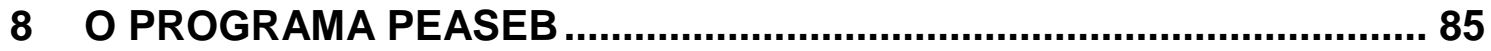

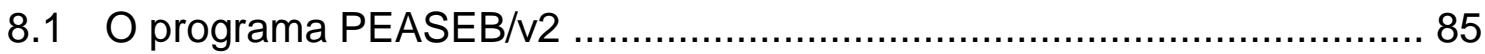

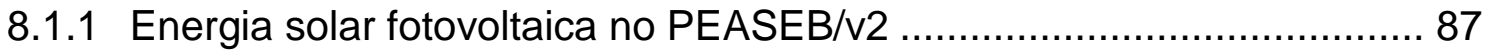

8.1.2 A energia da Biomassa no PEASEB/v2 ........................................... 90

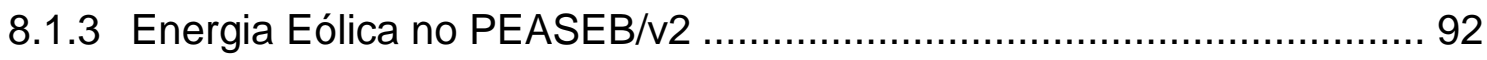

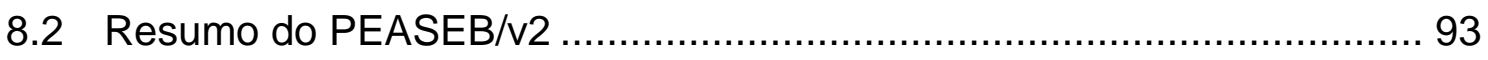

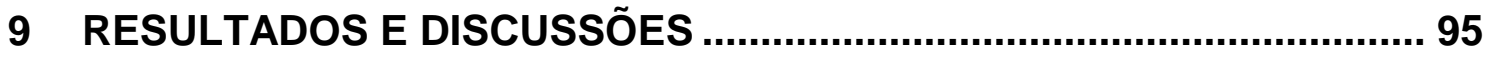

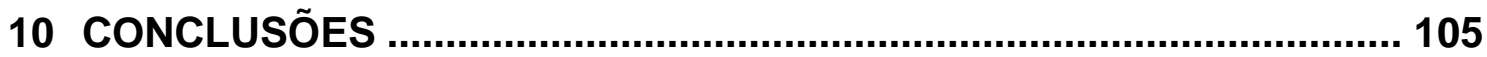

APÊNDICE A - BANCO DE DADOS DOS MUNICÍPIOS DA REGIÃO NORDESTE COM ATÉ 10.000 HABITANTES.......................................... 107

APÊNDICE B - CONSOLIDAÇÃO DOS RESULTADOS …............................ 119

B.1 - Consolidação dos resultados para Alagoas ........................................ 119

B.2 - Consolidação dos resultados para a Bahia........................................ 121 
B.3 - Consolidação dos resultados para o Ceará ........................................ 124

B. 4 - Consolidação dos resultados para o Maranhão................................... 125

B.5 - Consolidação dos resultados para a Paraíba ....................................... 127

B.6 - Consolidação dos resultados para Pernambuco ................................ 131

B.7 - Consolidação dos resultados para o Piauí......................................... 132

B.8 - Consolidação dos resultados para o Rio Grande do Norte................... 137

B.9 - Consolidação dos resultados para Sergipe ....................................... 140

APÊNDICE C - Programação em VBA do Cálculo da Viabilidade Econômica da Energia Solar Fotovoltaica - Sistema Isolado....................................... 141

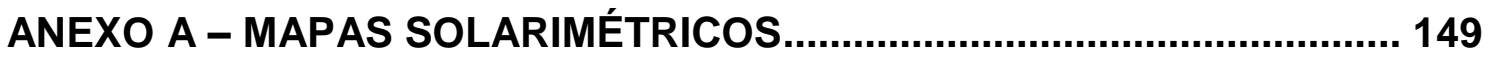

A.1 - Média anual do total diário de irradiação solar global incidente no território

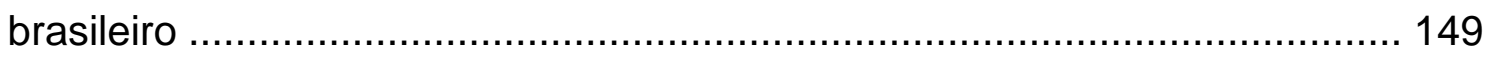

A. 2 - Médias sazonais da irradiação global diária no território brasileiro....... 150

ANEXO B - MAPAS DO POTENCIAL DE GERAÇÃO DE ENERGIA DA BIOMASSA (RESÍDUOS AGRÍCOLAS E ÓLEO DE DENDÊ) NA REGIÃO

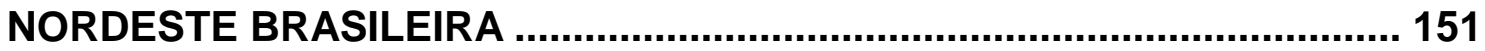

B.1 - Potencial de geração de energia a partir de resíduos agrícolas no Nordeste do Brasil 151

B.2 - Potencial de geração de energia a partir da biomassa do óleo de dendê no

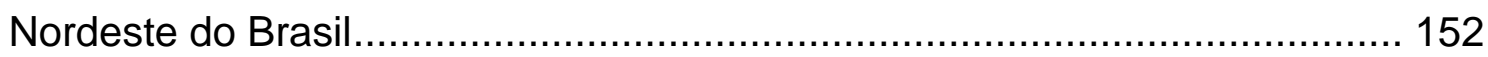

ANEXO C - MAPAS DO POTENCIAL EÓLICO BRASILEIRO ..................... 153

C. 1 - Velocidade média anual do vento a 50 metros de altura em $\mathrm{m} / \mathrm{s}$......... 153

C.2 - Velocidade média anual de vento a 50 metros de altura no Nordeste do Brasil 


\section{LISTA DE TABELAS}

TABELA 1.1 - IDHM dos estados do Nordeste.

TABELA 1.2 - Produção de energia e eletricidade na região Nordeste brasileira em 2011

TABELA 1.3 - Consumo residencial de eletricidade na região Nordeste brasileira em 2011

TABELA 1.4 - Capacidade instalada de geração elétrica na região Nordeste brasileira

TABELA 4.1 - Emissões referentes à fase de geração de eletricidade .33

TABELA 5.1 - Valores dos componentes de um sistema solar fotovoltaico (minirrede) de $200 \mathrm{kWh} /$ mês (MIGDI) para o Nordeste brasileiro .44

TABELA 5.2 - Valores dos componentes de um sistema solar fotovoltaico de 80kWh/mês (SIGFI80) para o Nordeste brasileiro (sistema isolado) 48

TABELA 6.1 - Potencial de produção de biogás a partir de suínos no Nordeste brasileiro*

TABELA 6.2 - Potencial da geração de energia a partir de resíduos de cana-deaçúcar no Nordeste brasileiro em um cenário de $30 \mathrm{kWh} / \mathrm{t}$ cana .52

TABELA 6.3 - Potencial da geração de energia a partir de resíduos de cana-deaçúcar no Nordeste brasileiro em um cenário de $60 \mathrm{kWh} / \mathrm{t}$ cana .52

TABELA 6.4 - Potencial da geração de energia a partir de resíduos de cana-deaçúcar na região Nordeste brasileira em um cenário de $120 \mathrm{kWh} / \mathrm{t}$ cana .52

TABELA 6.5 - Potencial da geração de energia a partir da biomassa do óleo de dendê no Nordeste brasileiro

TABELA 6.6 - Potencial da geração de energia a partir da biomassa de resíduos agrícolas no Nordeste brasileiro .53

TABELA 6.7- Potencial da geração de energia a partir de resíduos da silvicultura no Nordeste brasileiro com eficiência de $15 \%$

TABELA 6.8 - Potencial da geração de energia a partir de resíduos da silvicultura no Nordeste brasileiro com eficiência de $30 \%$ .53

TABELA 6.9 - Custo do $\mathrm{m}^{2}$ da casa de máquinas .60

TABELA 6.10 - Correção dos valores de custos para resíduos agrícolas .63 
TABELA 6.11 - Valores dos componentes dos custos de um sistema baseado em

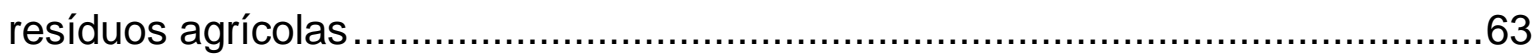

TABELA 6.12 - Correção dos valores de custos para óleo de dendê ..................70 TABELA 6.13 - Valores dos componentes dos custos de um sistema baseado em óleo de dendê ................................................................................. 70

TABELA 7.1 - Potencial eólico-elétrico estimado do Brasil calculado por integração de área nos mapas temáticos .76

TABELA 7.2 - Evolução da produção e do consumo de energia eólica no Brasil (GWh)

TABELA 9.1 - Amostragem dos resultados para energia solar fotovoltaica em minirredes .96

TABELA 9.2 - Amostragem dos resultados para energia solar fotovoltaica em sistemas isolados

TABELA 9.3 - Amostragem dos resultados para biomassa de resíduos agrícolas .98

TABELA 9.4 - Amostragem dos resultados para biomassa de óleo de dendê.....99

TABELA 9.5 - Amostragem dos resultados para energia eólica.........................100

TABELA 9.6 - Valores por kWh para as fontes alternativas de energia .............101

TABELA 9.7 - Variação percentual entre os valores por kWh das fontes alternativas de energia considerando a externalidade 102 


\section{LISTA DE FIGURAS}

FIGURA 1.1 - Matriz Elétrica Brasileira em 2011 ............................................4

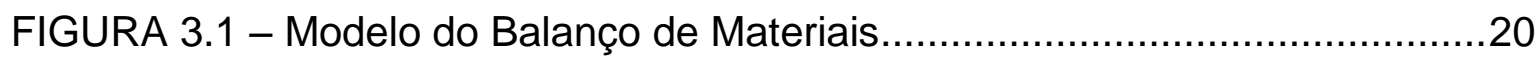

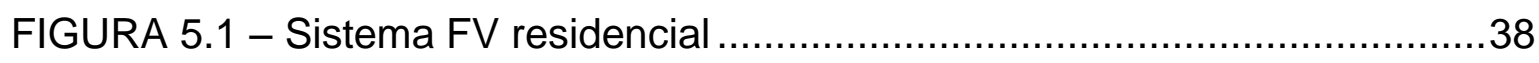

FIGURA 6.1 - Oferta Interna de Energia Elétrica por fonte .................................51

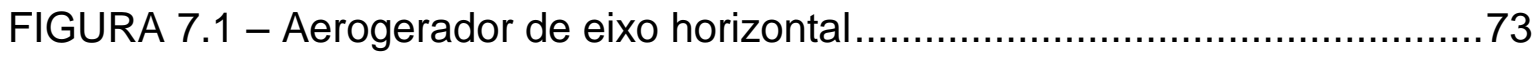

FIGURA 7.2 - Configuração de um sistema eólico isolado .................................74

FIGURA 7.3 - Potencial eólico estimado por região do Brasil ...............................77

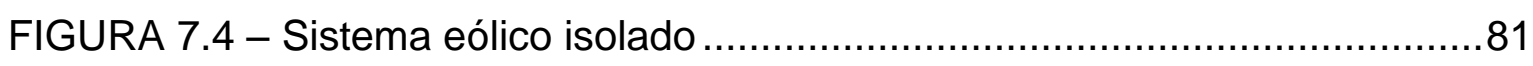

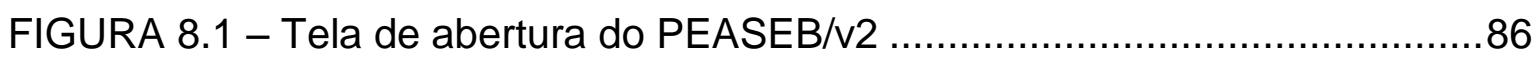

FIGURA 8.2 - Cálculo da Viabilidade Econômica para Solar - Sistema Isolado..88

FIGURA 8.3 - Tabela para a Energia Solar - Sistema Isolado.............................89

FIGURA 8.4 - GRAFSOLARSI : Solar - Sistema Isolado .................................8

FIGURA 8.5 - Cálculo da Viabilidade Econômica para Solar - Minirredes ...........90

FIGURA 8.6 - Cálculo da Viabilidade Econômica para Biomassa - Resíduos

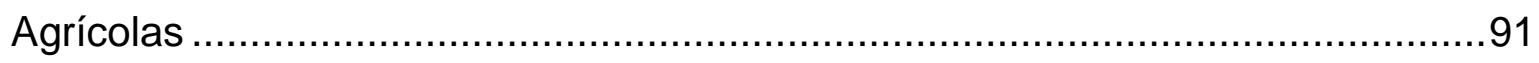

FIGURA 8.7 - Cálculo da Viabilidade Econômica para Biomassa - Óleo de Dendê .92

FIGURA 8.8 - Cálculo da Viabilidade Econômica para Energia Eólica .................93

FIGURA 8.9 - Descrição do PEASEB/v2 ...........................................................94 


\section{INTRODUÇÃO}

O modelo energético da maioria dos países está baseado no consumo de combustíveis fósseis. Estima-se que os combustíveis fósseis representem $90 \%$ do consumo energético no mundo, e sua utilização para a produção de energia é responsável pela adição anual de mais de 5 bilhões de toneladas de carbono na atmosfera, além da emissão de outros gases de efeito estufa, responsáveis pelas crescentes alterações climáticas no planeta. Desde 1900, a temperatura média

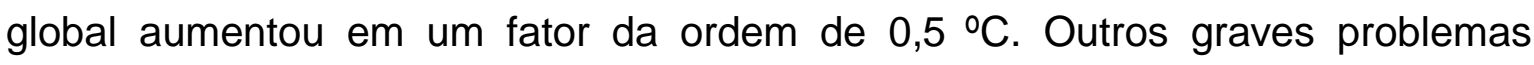
associados às emissões provindas da geração de energia, que utilizam fontes fósseis, são: a chuva ácida e os severos problemas de saúde na população mundial devido à exposição aos poluentes emitidos (Hinrichs e Kleinbach, 2003).

O termo aquecimento global descreve o aumento da temperatura média da superfície terrestre devido à emissão de gases, como o dióxido de carbono $\left(\mathrm{CO}_{2}\right)$, metano $\left(\mathrm{CH}_{4}\right)$ e óxido nitroso $\left(\mathrm{N}_{2} \mathrm{O}\right)$. Esse aquecimento é provocado pelo chamado efeito estufa, que impede que uma fração da energia solar recebida na superfície terrestre retorne ao espaço. Nas últimas décadas, a concentração desses gases na atmosfera aumentou substancialmente. No caso do $\mathrm{CO}_{2}$, as concentrações na atmosfera nos anos de 1800 não passavam de 290 partes por milhão (ppm) (Massambani, 1992). Em 2013, esse volume passou para mais de 400 ppm (Folha de São Paulo, 2013). Mais da metade desse aumento ocorreu após 1950, principalmente devido à utilização e queima de combustíveis fósseis pela atividade humana (Massambani, 1992).

Projeções do Painel Intergovernamental sobre as Mudanças Climáticas (IPCC) demonstram que, até 2025, cerca de 12,43 bilhões de toneladas de carbono serão emitidas para a atmosfera a partir do setor energético, sendo que $56 \%$ desse montante serão provenientes dos países em desenvolvimento, como o Brasil (Massambani, 1992).

De acordo com Massambani (1992), tendo as projeções do IPCC como base, num cenário com pouco ou nenhum controle sobre as emissões, projeta-se, em 2025, um aumento da temperatura média global de cerca de 4 graus acima do período pré-industrial. Os outros cenários projetados com os controles das 
emissões preveem que em 2100 haverá um aumento da temperatura média global entre 1,8 e 2,8 graus acima do valor pré-industrial.

Previsões sobre o consumo de energia para o século XXI sugerem um aumento contínuo das emissões de dióxido de carbono: de 7,4 bilhões de toneladas por ano em 1997 para aproximadamente 26 bilhões de toneladas em 2100 (Silva et. al. 2000).

Três quartos da população mundial vivem nos países em desenvolvimento. Apenas um quarto de toda a energia gerada mundialmente é consumida por esses países, o que leva a uma grande disparidade na comparação do consumo per capita entre os países. O consumo dos países em desenvolvimento quadruplicou a partir de 1960, ocasionando grandes problemas na qualidade do ar e de outros recursos ambientais. A China, por exemplo, gera $75 \%$ de sua eletricidade a partir do carvão, fonte fóssil altamente poluidora. Estima-se ainda que, em duas décadas, as emissões de $\mathrm{CO}_{2}$ dos países em desenvolvimento devem passar de $28 \%$ para $44 \%$ das emissões globais (Hinrichs e Kleinbach, 2003).

Torna-se claro que o aquecimento global e suas implicações dificilmente regredirão. É preciso revisar os processos relacionados às atividades humanas que são os grandes responsáveis pela emissão de $\mathrm{CO}_{2}$ para a atmosfera, como por exemplo, a substituição dos combustíveis fósseis para a produção de energia (Massambani, 1992).

É necessário pensar em um desenvolvimento sustentável da economia, considerando, de forma conjunta, os pilares social, ambiental e econômico para que o desenvolvimento atual não comprometa as gerações vindouras.

As políticas econômicas podem ser um instrumento eficaz para a sustentação dos ecossistemas e manutenção dos recursos naturais, já que, na falta de incentivos econômicos adequados, as políticas de proteção ambiental são desconsideradas. Isso pode ocorrer devido à tendência em tratar o meio ambiente como ilimitado ou gratuito, incentivando assim a exaustão e a degradação dos recursos ambientais (Mattos e Mattos, 2004).

De acordo com Hinrichs e Kleinbach (2003), o crescimento econômico de forma sustentável só será possível com o uso eficiente dos limitados recursos energéticos, do desenvolvimento de novas tecnologias e da utilização de fontes alternativas especialmente nos países em desenvolvimento. Do ponto de vista 
econômico, o crescimento precisa ser definido de acordo com a capacidade de suporte dos ecossistemas, respeitando os limites do meio ambiente físico para, assim, se ter o desenvolvimento de forma sustentada (Mattos e Mattos, 2004).

A redução da oferta de combustíveis convencionais juntamente com ao aumento de demanda por energia e a preocupação crescente com o meio ambiente impulsionam a comunidade cientifica a buscar alternativas, pesquisando e desenvolvendo fontes para geração de energia que sejam menos poluentes, renováveis e de baixo impacto ambiental (Pereira et al., 2006).

As fontes alternativas de energia surgem como opção, pois não emitem gases poluentes por utilizarem matérias-primas renováveis, contribuindo assim para a sustentabilidade almejada pelos países em desenvolvimento (Goldemberg, 2007). As principais fontes alternativas de energia estudadas nesse trabalho são: eólica, solar e biomassa, que têm se destacado, principalmente no Brasil, por conta do Programa de Incentivo às Fontes Alternativas de Energia Elétrica (PROINFA) e da Coordenação Geral de Fontes Alternativas de Energia do Ministério de Minas e Energia (PROINFA, 2012).

O PROINFA, maior programa de incentivo às fontes alternativas de energia do mundo, foi instituído pela Lei 10.438/2002 com o objetivo de aumentar a participação da energia elétrica produzida por empreendimentos com base em fontes eólicas, biomassa e Pequenas Centrais Hidrelétricas ( $\mathrm{PCH}^{\prime} \mathrm{s}$ ) no Sistema Interligado Nacional (SIN), promovendo a diversificação da matriz energética do país, aumentando, assim, a segurança do abastecimento e valorizando as características e potenciais de cada região. O programa previu a instalação de 144 usinas, totalizando 3.299,40 MW de capacidade instalada, sendo 1.191,24 MW provenientes de $63 \mathrm{PCHs}, 1.422,92 \mathrm{MW}$, de 54 usinas eólicas e 685,24 MW, de 27 usinas à base de biomassa. $O$ prazo para o inicio do funcionamento dos empreendimentos era 30 de dezembro de 2010, de acordo com a Lei n. .011 .943 , de 28 de maio de 2009 (ELETROBRÁS, 2014; PROINFA, 2012).

Até 31 de dezembro de 2011 foram implantados através do PROINFA 119 empreendimentos, sendo 41 eólicas, 59 PCH's e 19 térmicas a biomassa, totalizando 2.649,87 MW de capacidade instalada, o suficiente para abastecer aproximadamente 4,5 milhões de usuários. Do total instalado 963,99 MW são gerados pelas usinas eólicas, 1.152,54 MW por $\mathrm{PCH}^{\prime}$ s e 533,34 MW pelas usinas térmicas a biomassa (Eletrobrás, 2014). 
Essas fontes podem ser importantes também pelo seu potencial de inserção econômica e social de populações excluídas, gerando emprego e renda com custos ambientais reduzidos em comparação com outras fontes. De acordo com a Eletrobrás (2014), o PROINFA foi responsável pela geração de cerca de 150 mil empregos diretos e indiretos em todo o país. Além disso, o programa possibilita uma redução estimada de emissões de gases de efeito estufa equivalentes a aproximadamente 2,5 milhões de toneladas de CO2eq/ano.

De acordo com a Empresa de Pesquisa Energética (EPE, 2012b) as emissões antrópicas, que resultam das ações dos seres humanos associadas à matriz energética do país, totalizaram 396,7 $\mathrm{Mt} \mathrm{CO}_{2}$ equivalente (eq.) em 2011. A intensidade de carbono da economia do Brasil foi de 0,16 $\mathrm{kg} \mathrm{CO}_{2} / \mathrm{US} \$$ em 2011, com uma emissão de cerca de $2,1 \mathrm{t} \mathrm{CO}_{2}$ eq. por habitante. A participação das fontes renováveis na matriz energética brasileira foi de $44,1 \%$ no ano de referência.

Para produzir 1MWh de energia, o setor elétrico brasileiro emitiu, em 2011, $56 \mathrm{~kg} \mathrm{CO} 2$ em média, quantidade 12 vezes menor que as emissões da China, país também em desenvolvimento. Isso se deve à participação de $88,9 \%$ das fontes renováveis na matriz elétrica (EPE, 2012b), sendo a maior parte proveniente de fonte hídrica, como pode ser visto na FIG. 1.1.

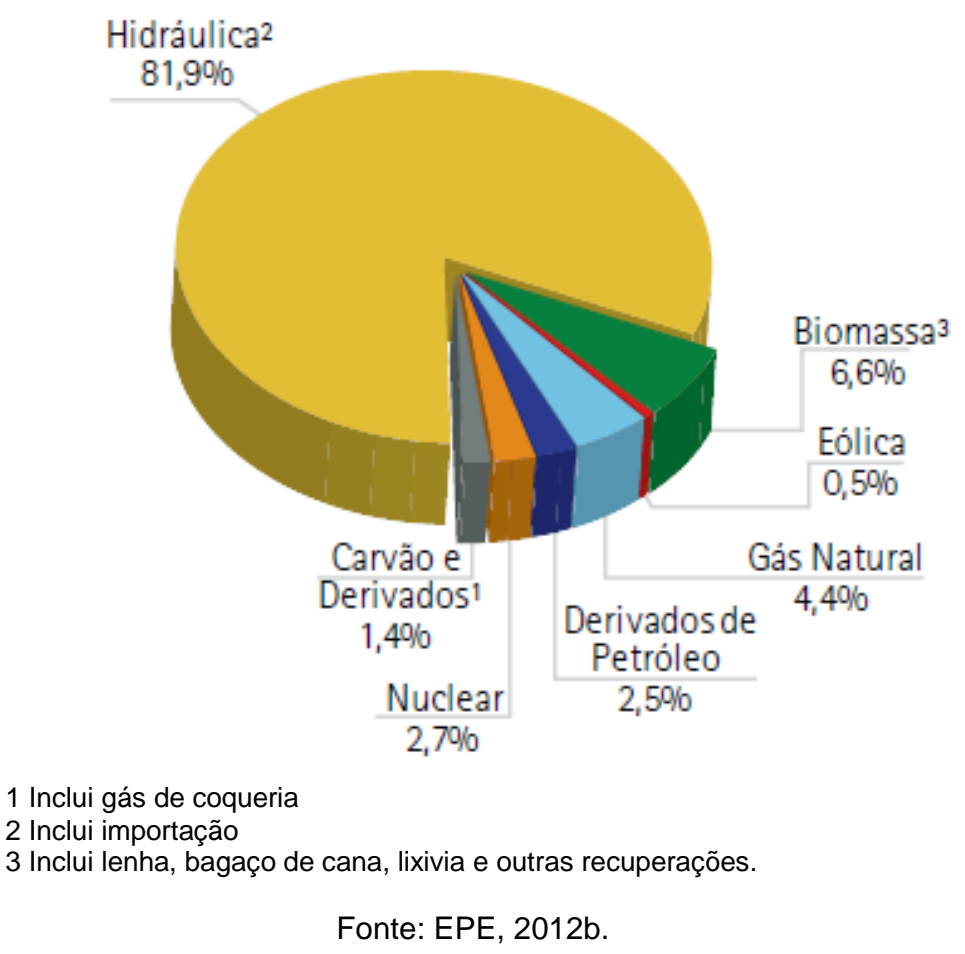

FIGURA 1.1 - Matriz Elétrica Brasileira em 2011 
No Brasil, de acordo com dados do PROINFA (2012), 43,9\% da Oferta Interna de Energia (OIE), que é toda a energia disponibilizada para ser transformada, distribuída e consumida nos processos produtivos do país, é de origem renovável, situação privilegiada em relação ao resto do mundo, cuja média mundial é de $14 \%$, enquanto a dos países desenvolvidos é de $6 \%$.

Um aspecto importante a ser considerado na escolha das melhores alternativas energéticas, tendo como foco um desenvolvimento mais limpo e sustentável, diz respeito à análise das externalidades advindas dessas fontes, ou seja, os custos e benefícios que atingirão a sociedade como um todo. É preciso identificar essas externalidades e valorá-las de forma adequada para que os custos ou benefícios possam ser internalizados no preço final do produto e, assim, refletir de forma correta a viabilidade ou não viabilidade econômica destas fontes.

Os agentes econômicos devem ter ciência dos valores dos bens e serviços ou dos custos que a sociedade precisará arcar no caso da diminuição dos recursos ambientais ou prejuízo dos mesmos, já que dependem do meio ambiente como fonte de matérias-primas (Mattos e Mattos, 2004).

No âmbito das Ciências Econômicas, a internalização dos custos ambientais é um problema da Microeconomia, onde a questão ambiental tem sido trabalhada para a internalização dos efeitos ambientais da produção no preço do produto, que fará com que o preço final reflita a degradação ambiental e também a sua recuperação (Mattos e Mattos, 2004). Dentro dessa análise, é necessário também considerar os conceitos de avaliação econômica e financeira para uma correta análise de viabilidade econômica.

Essas considerações apontaram para a necessidade de ter um estudo detalhado com relação ao custo ambiental de fontes alternativas de energia para estimar sua viabilidade econômica em pequenas comunidades da região Nordeste do Brasil .A seguir, serão descritos os indicadores que levaram à escolha dessa região para o estudo.

\subsection{O Nordeste brasileiro}

A falta de acesso à eletricidade reflete diretamente nas condições de vida e nos Índices de Desenvolvimento Humano (IDH) de regiões não eletrificadas. 
O IDH do Nordeste brasileiro em 2005 era de 0,720 , o mais baixo entre as regiões brasileiras. Ainda em 2005, os nove estados que compõem a região situavam-se nas últimas colocações no ranking nacional, sendo Alagoas o pior Estado em número de IDH no país (Banco Central do Brasil, 2009).

De acordo com o PNUD (2014), a partir dos dados do último Altas do Desenvolvimento Humano no Brasil, o Nordeste ainda está em situação desfavorável comparado as outras regiões do país. Entre os 27 unidades da federação, os estados nordestinos classificaram-se conforme a TAB. 1.1 de acordo com o IDH Municipal (IDHM) das regiões em análise:

TABELA 1.1 - IDHM dos estados do Nordeste

\begin{tabular}{c|c|c}
\hline $\begin{array}{c}\text { Colocação no ranking das } \\
\text { unidades da Federação }\end{array}$ & Estado & IDHM \\
\hline $16^{\circ}$ & Rio Grande do Norte & 0,684 \\
$17^{\circ}$ & Ceará & 0,682 \\
$19^{\circ}$ & Pernambuco & 0,673 \\
$20^{\circ}$ & Sergipe & 0,665 \\
$22^{\circ}$ & Bahia & 0,660 \\
$23^{0}$ & Paraíba & 0,658 \\
$24^{\circ}$ & Piauí & 0,646 \\
$26^{\circ}$ & Maranhão & 0,639 \\
$27^{\circ}$ & Alagoas & 0,631 \\
\hline
\end{tabular}

Fonte: PNUD (2014).

O acesso à energia elétrica pode representar uma melhor qualidade de vida para populações já que possibilita, entre outros fatores, atividades produtivas associadas à geração de energia, (Coelho et al., 2005).

Para levar energia elétrica a essas comunidades afastadas, uma opção é a inserção de fontes alternativas de energia nessas regiões. Para Coelho et al. (2005), é preciso inserir fontes disponíveis localmente. As condições de isolamento e dispersão dessas regiões necessitam de soluções que valorizem os recursos naturais locais, que causem o menor impacto possível ao meio ambiente. 
A seguir, nas TABELAS 1.2, 1.3 e 1.4, são apresentados os dados sobre consumo, capacidade instalada e produção de energia no Nordeste do Brasil em 2011.

TABELA 1.2 - Produção de energia e eletricidade na região Nordeste brasileira em 2011

\begin{tabular}{c|c|c}
\hline Estado & $\begin{array}{c}\text { Produção de energia - fontes } \\
\text { fósseis }^{*}\left(\mathbf{1 0}^{\mathbf{3}} \mathbf{m}^{\mathbf{3}}\right)\end{array}$ & $\begin{array}{c}\text { Produção de energia - } \\
\text { eletricidade (GWh) }\end{array}$ \\
\hline Maranhão & - & 1.943 \\
Piauí & - & 742 \\
Ceará & 447 & 2.578 \\
Rio Grande do Norte & 4038 & 1.587 \\
Paraíba & - & 389 \\
Pernambuco & - & 7.707 \\
Alagoas & 882 & 18.747 \\
Sergipe & 3.539 & 9.670 \\
Bahia & 5.105 & 23.608 \\
\hline Total da região Nordeste & 14.011 & 66.971 \\
\hline Total do Brasil & 151.686 & 531.758 \\
\hline
\end{tabular}

*Foram consideradas como fontes fósseis o petróleo e o gás natural. A região Nordeste não possui produção de carvão mineral, conforme dados da EPE (2012).

Fonte: EPE, 2012a,

A produção de energia elétrica na região Nordeste brasileira é liderada pelo estado da Bahia, com uma produção de 23.608 GWh em 2011. A produção total da região é de $66.971 \mathrm{GWh}$ em 2011, correspondente a aproximadamente $12,59 \%$ do total produzido no país no ano de referência. A região responde por aproximadamente $9,2 \%$ da produção de energia por meio de fontes fósseis no país. 
TABELA 1.3 - Consumo residencial de eletricidade na região Nordeste brasileira em 2011

\begin{tabular}{c|c}
\hline Estado & Consumo (GWh) \\
\hline Maranhão & 2.041 \\
Piauí & 1.029 \\
Ceará & 3.032 \\
Rio Grande do Norte & 1.531 \\
Paraíba & 1.356 \\
Pernambuco & 3.933 \\
Alagoas & 1.020 \\
Sergipe & 854 \\
Bahia & 5.367 \\
\hline Total da região Nordeste & 20.163 \\
\hline Total do Brasil & 111.971 \\
\hline
\end{tabular}

Fonte: EPE, 2012a.

O consumo de eletricidade na região em 2011 foi de 20.163 GWh, o que corresponde a aproximadamente 18\% de todo o consumo do país em 2011.

TABELA 1.4 - Capacidade instalada de geração elétrica na região Nordeste brasileira*

\begin{tabular}{c|c}
\hline Estado & $\begin{array}{c}\text { Capacidade instalada total (SP e APE) } \\
(\text { MW) }\end{array}$ \\
\hline Maranhão & 885 \\
Piauí & 198 \\
Ceará & 1.418 \\
Rio Grande do Norte & 784 \\
Paraíba & 637 \\
Pernambuco & 1.956 \\
Alagoas & 3.981 \\
Sergipe & 1.645 \\
Bahia & 6.627 \\
\hline Total da região Nordeste & 18.131 \\
\hline Total do Brasil & 117.135 \\
\hline
\end{tabular}

* São consideradas hidro, termo e eólica. A região Nordeste não possui geração a partir de fontes nucleares.

SP - Serviço público, incluindo produtores independentes

APE - Autoprodutores. Não inclui usinas hidrelétricas em consórcio com concessionárias de serviço público.

Fonte: EPE, 2012a. 
A capacidade instalada para geração elétrica da região Nordeste brasileira corresponde a aproximadamente $15,5 \%$ do total instalado no país no ano de 2011.

Então, é possível verificar, a partir dos dados das TAB. 1.2, TAB. $1.3 \mathrm{e}$ TAB. 1.4 que a região Nordeste brasileira, mesmo sendo expressiva no país e possuidora de grandes recursos para a geração de energia elétrica, ainda participa com uma pequena parcela na produção nacional de eletricidade $12,59 \%$ aproximadamente e conta com muitas áreas sem eletrificação, o que leva a necessidade de avaliar a viabilidade de utilização de fontes alternativas de energia para geração de eletricidade disponíveis em abundância na região.

Ainda, a região conta com os mais baixos índices de desenvolvimento humano do pais, fator que pode ser influenciado pelos níveis de consumo e acesso à energia.

Assim, os objetivos desse estudo foram fundamentados e serão apresentados a seguir.

\subsection{Objetivos}

Esse trabalho tem como objetivos calcular o custo ambiental, na fase de geração de eletricidade, para as fontes alternativas de energia - solar, eólica e biomassa - e estimar a viabilidade econômica dessas fontes em pequenas comunidades da região Nordeste do Brasil.

Como resultado, será feito um aperfeiçoamento dos cálculos de viabilidade econômica para as fontes em questão, com a inserção dos seus respectivos custos ambientais no Programa de Cálculo de Custos de Energias Alternativas, Solar, Eólica e Biomassa (PEASEB), desenvolvido no trabalho de Vanni (2008).

\subsection{Motivação do trabalho}

A motivação desse trabalho foi promover uma melhor avaliação dos custos ambientais das fontes alternativas de energia estudadas. Em 2008, no trabalho de Vanni, onde a primeira versão do PEASEB foi gerada, assumiu-se um valor padrão de $10 \%$ a mais do custo total do empreendimento para todas as fontes. 
A partir dos resultados, espera-se ter uma estimativa mais realista da viabilidade econômica das fontes solar, eólica e biomassa, considerando a internalização dos custos ambientais no custo total do empreendimento.

Não há a pretensão de se esgotar o tema, pois uma análise de todas as fases da produção de eletricidade - implementação do empreendimento, geração de eletricidade e desativação da instalação - demandaria um período superior ao disponível para o desenvolvimento desse trabalho.

Pretende-se, com esse estudo, contribuir para as políticas energéticas do país e, também, para as políticas de investimento dos setores público e privado.

\subsection{Capítulos}

No Capítulo 1, uma introdução forneceu uma visão geral do estudo desenvolvido, os objetivos do trabalho e as motivações que levaram à escolha do tema.

A revisão bibliográfica sobre os trabalhos relevantes ao tema, envolvendo externalidades, valoração ambiental e viabilidade econômica de fontes de energia com foco nas fontes alternativas de energia é apresentada em ordem cronológica no Capítulo 2.

O Capítulo 3 aborda as principais questões relacionadas à economia e meio ambiente. São dadas as definições e diretrizes da Economia Ambiental pertinentes ao trabalho desenvolvido.

O Capítulo 4 apresenta a descrição do método que será utilizado para os cálculos de custos ambientais referentes à viabilidade econômica.

Nos Capítulos 5, 6 e 7 são demonstradas as equações para os cálculos e viabilidade econômica das fontes de energia solar, biomassa e eólica, considerando os seus custos ambientais, além de uma breve descrição de cada uma das fontes.

No Capítulo 8 é descrito o programa PEASEB, após a inserção das equações desenvolvidas nos capítulos 5, 6 e 7 .

No Capítulo 9, são apresentados os resultados e as discussões acerca dos resultados.

As conclusões e propostas futuras estão no capítulo 10. 
O APÊNDICE A apresenta o banco de dados criado com os municípios da região nordeste brasileira.

O APÊNDICE $\mathrm{B}$ reúne a consolidação dos resultados para os nove estados nordestinos estudados.

O APÊNDICE C demonstra a programação do PEASEB/v2, considerando a variável ambiental para sistemas solares fotovoltaicos em sistemas isolados.

Os mapas solarimétricos do país podem ser vistos no ANEXO A.

O ANEXO B exibe os mapas do potencial de geração de energia da biomassa de resíduos agrícolas e de óleo de dendê na região nordeste brasileira.

Os mapas do potencial eólico brasileiro são apresentados no ANEXO C. 


\section{REVISÃO BIBLIOGRÁFICA}

Nesta revisão da literatura são apresentados trabalhos relacionados à economia e ao meio ambiente. Foram também considerados trabalhos recentes sobre o cálculo e a internalização dos custos ambientais por meio da valoração econômica dos recursos naturais, além de textos que tratam da viabilidade econômica de fontes alternativas de energia, tema que também é abordado nesta dissertação.

Custos ambientais e externalidades são temas que tem sido repetidamente debatidos pela sociedade moderna, principalmente devido aos efeitos ambientais devastadores causados nos últimos anos pelo rápido desenvolvimento econômico e tecnológico no mundo. No Brasil, a partir de 1992, quando aconteceu a Eco 92, o assunto tomou fôlego e passou a ser tema recorrente. No entanto, essa temática de custos ambientais e a preocupação com as externalidades já podiam ser observadas no início do século XX em trabalhos importantes de grandes economistas, como Pigou e Coase. Esses autores tentaram valorar os custos impostos à sociedade pelas externalidades, que influenciaram e serviram de base para toda a teoria da Economia Ambiental. Desde então, mais estudiosos têm se dedicado ao tema, e a evolução dos estudos será descrita a seguir.

Arthur Cecil Pigou, economista inglês, é considerado o fundador da Economia do bem-estar. Em sua publicação, The economics of welfare (1920), Pigou estabeleceu as diferenças entre custos marginais privados e sociais e defendeu a intervenção do Estado na economia por meio da tributação (posteriormente conhecida como Taxa de Pigou), para corrigir as falhas de mercado e internalizar as externalidades geradas pelos agentes econômicos. Isso fez com que os custos marginais do produtor, repassados para a sociedade, fossem incorporados aos seus custos. Assim, o produtor ficaria com o custo total da produção. As ideias desse autor o tornaram um precursor na área ambiental.

Em outubro de 1960, o economista Ronald H. Coase publicou um importante trabalho na área microeconômica e do bem-estar social, intitulado "The problem of social cost" (O problema do custo social), que daria origem ao atual Teorema de Coase, termo amplamente utilizado em trabalhos ligados à área 
ambiental. Em suas análises, Coase contraria a tradição Pigouviana, amplamente adotada até então pelos economistas da época, em que os custos sociais eram originados por falhas de mercado e deveriam ser corrigidos pelo Estado por meio de medidas impostas aos causadores do impacto. Para Coase, o problema das externalidades tinha origem na indefinição dos direitos de propriedade e na ausência de mercados que possibilitavam a internalização dos custos. A solução deveria ser pensada a partir da natureza recíproca do problema. O autor apresentou algumas soluções para maximizar o bem-estar social a partir de direitos de propriedade bem definidos negociados entre as partes envolvidas. A partir da definição dos direitos de propriedade e, desde que houvesse uma negociação sem custos de transação entre as partes, as externalidades ou ineficiências econômicas poderiam ser corrigidas.

Em 1991, Pearce et. al. afirmavam que para que houvesse uma melhor alocação dos recursos na economia seria importante fazer uma avaliação econômica adequada dos bens e serviços ambientais. Uma melhoria na qualidade ambiental proporcionaria também melhorias na satisfação e no bem-estar social, medidos pela Economia Ambiental. E uma forma de fazer essas medidas seria por intermédio da monetização das externalidades. De acordo com esses autores, a quantificação monetária permite, também, a comparação com usos alternativos dos recursos. Para tanto, eles descreveram a equação geral para a valoração econômica dos recursos ambientais, aqui chamada de Valor Econômico Total e suas metodologias e concluíram que a valoração força a sociedade a pensar racionalmente nas decisões, nos custos e benefícios das decisões tomadas.

Reis (2001) estudou os custos ambientais associados à geração elétrica por hidrelétricas e também termelétricas a gás natural e apresentou metodologias para a valoração desses custos decorrentes dos principais danos levantados para as fontes estudadas. Dispositivos econômicos da época não identificavam a degradação ambiental em níveis micro ou macroeconômicos. A internalização dos custos da degradação ambiental requer a quantificação desses danos, ou seja, valores obtidos a partir dos métodos de valoração econômica. Foram levantados os principais aspectos teóricos, as metodologias para valoração ambiental, a internalização dos custos gerados, os impactos gerados pelas fontes e as metodologias que poderiam ser aplicadas para valorar os principais danos causados. Para o autor, uma incorporação incompleta dos custos 
ambientais leva à alocação incorreta dos recursos, a não satisfação do bem-estar das pessoas e à geração de passivos ambientais no caso de externalidades negativas. Mas também, no caso de externalidades positivas, a correta internalização das externalidades pode demonstrar a viabilidade de um empreendimento.

Ainda em 2001, Reis et. al. discutiram aspectos conceituais e metodológicos de duas metodologias que pudessem incorporar as externalidades aos demais aspectos de análise do setor elétrico, a saber: Avaliação dos Custos Completos (ACC) e Análise do Ciclo de Vida (ACV). A ACV tem como objetivo a avaliação comparativa dos sistemas em termos ambientais, não produzindo valores. A ACC admite as externalidades como custos externos e busca monetizá-los internalizando os custos. Dentro dos elementos constituintes da ACC, o que diferencia esse método de outros é a incorporação das externalidades nos custos, que é feita em três etapas: identificação e estimativa dos impactos socioambientais; quantificação das externalidades e monetarização das externalidades, sendo esse último item o de maior dificuldade. Os autores concluíram, depois de expor as metodologias, que ambas incorporam as questões socioambientais e são passíveis de serem utilizadas no planejamento integrado de recursos.

Mattos e Mattos (2004) analisaram a internalização dos custos ambientais do setor sucroalcooleiro a partir do estudo dos impactos da queima prévia da cana-de-açúcar para a colheita, da quantificação dos usos alternativos da palha, no caso da substituição da queima prévia pela colheita da cana crua e da utilização do bagaço no setor produtivo. O trabalho buscou quantificar os impactos do setor no meio ambiente e sua possível viabilidade econômica pelo método de valoração econômica. Para esse objetivo, utilizou-se a equação do valor econômico total que será discutida em capítulo específico. Os autores concluíram que a valoração feita de forma simples, deixando de fazer a queima previa nas colheitas, pode ser usada como indenização nos casos de descumprimentos das Leis Ambientais. Além disso, os autores mostraram que a utilização da palha para a geração de energia e o bagaço, para fins com maior valor agregado, tornariam o setor mais viável economicamente.

Reis et. al. (2005) publicaram um trabalho apresentando os resultados de um projeto desenvolvido pela equipe cujo principal objetivo era estabelecer 
uma metodologia de avaliação e incorporação dos custos socioambientais em novos projetos de transmissão. Nele foi desenvolvido um software buscando o aprimoramento da questão da avaliação ambiental. Para atingir o objetivo, os aspectos abordados foram: levantamento, organização e apresentação dos aspectos básicos da transmissão de energia elétrica; análise da inserção ambiental de linhas de transmissão de energia elétrica (fonte de grande parte das externalidades do projeto) e o desenvolvimento do sistema para mensuração das externalidades. A metodologia foi desenvolvida, a partir dos conceitos de externalidades e foram feitas as devidas análises. Para comprovar a aderência do programa, foi feito um estudo de caso que comprovou que a inclusão das externalidades revelou um custo ambiental superior ao considerado no início do projeto estudado. Então, concluiu-se que a ferramenta desenvolvida é importante para o tratamento de custos, benefícios e externalidades dos projetos de linhas de transmissão.

Rodrigues (2005) estudou os impactos ambientais de tecnologias de plantio de soja e milho em região de cerrados, utilizando como técnica de valoração econômica o Método Custo-Reposição (MCR), que é baseado na reparação de danos aos recursos ambientais. A partir da mensuração dos impactos ambientais, o autor comparou duas alternativas tecnológicas: o plantio direto e o convencional. Ele concluiu que a adoção do plantio direto possui maior eficácia social, já que reduz a erosão dos solos e também o assoreamento. Os valores calculados pelo autor mostram que a adoção do plantio direto representaria uma redução nos custos ambientais para o município analisado, com exceção das outras externalidades ambientais não mensuradas. No caso da soja, a adoção do plantio direto eleva o custo de produção em 0,47\%, mas provoca uma redução de $81,22 \%$ no custo ambiental. Para o milho, os custos de produção do plantio direto são $5,92 \%$ menores do que os referentes ao plantio convencional, mas provoca uma redução no custo ambiental em 29,43\%.

Udaeta et. al. (2005) descrevem uma metodologia de avaliação dos impactos gerados por usinas hidrelétricas e termelétricas a gás natural utilizando a abordagem dos Custos Completos, a fim de buscar uma solução para o problema de aumento da oferta de energia com um menor ônus para a sociedade. Os aspectos considerados na análise de viabilização das usinas foram fatores técnico-econômicos, ambiental, social e político. Para as análises foram 
necessárias as caracterizações das usinas estudadas em todos os aspectos citados, e os principais impactos positivos e negativos de cada um dos fatores foram identificados, considerando pesos para cada um deles. Concluiu-se que a aplicação do modelo foi satisfatória para as usinas estudadas.

Brandli et. al. (2006) avaliaram a aplicabilidade dos métodos de valoração econômica ambiental por meio de estudos empíricos que analisaram as vantagens e limitações de alguns métodos da Função de Demanda. O trabalho evidenciou a importância da internalização dos custos ambientais pois, além de dimensionar os impactos ambientais internalizando-os à economia, também evidenciou os custos e benefícios da expansão da atividade humana, visando à maximização do bem-estar social e do desenvolvimento sustentável. De acordo com os autores, a escolha do melhor método deve considerar o objetivo da valoração, a eficiência do método para o caso e as informações disponíveis para o estudo. A partir da análise dos casos valorados por cada método, o grupo concluiu que o método de valoração contingente é o mais amplamente utilizado, devido à sua flexibilidade e capacidade de estimar o valor econômico total. Salienta-se, ainda, que todos os métodos ainda são pouco conhecidos e há necessidade do desenvolvimento de trabalhos que estimem o valor econômico dos recursos naturais.

Zampier e Miranda (2007) estudaram as metodologias para a valoração econômica de bens ambientais porque meio de uma revisão bibliográfica sobre o tema, com o objetivo de fazer uma avaliação da aplicabilidade desses métodos. Eles concluíram que a valoração do meio ambiente é um dos aspectos mais críticos do processo de contabilização devido à dificuldade de quantificação dos benefícios gerados e salientam a importância da valoração econômica nos processos de tomada de decisão por parte do poder público no que se refere ao desenvolvimento de forma sustentável.

Dantas Filho et al., (2008) analisaram a viabilidade econômica financeira de um projeto de cogeração de energia utilizando o bagaço de cana-deaçúcar considerando a possibilidade de inserção do projeto no mercado de crédito de carbono, já que a cogeração a partir de fontes alternativas e renováveis é tida como um dos projetos de maior elegibilidade do Mecanismo de Desenvolvimento Limpo (MDL). Esse trabalho considerou os impactos ambientais positivos gerados pela utilização energética desses resíduos e as emissões evitadas de $\mathrm{CO}_{2}$ que 
seriam gerados por fontes fósseis. As emissões evitadas foram quantificadas para o cálculo de créditos de carbono, e esses valores foram somados à Taxa Interna de Retorno (TIR) e ao Valor Presente Líquido (VPL) demonstrando que os resultados foram mais atrativos financeiramente quando o projeto é inserido no MDL, contabilizando-se os efeitos ambientais e sociais dos projetos.

Franco et al. (2008) analisaram a viabilidade econômica da geração de energia elétrica utilizando células a combustível em uma comunidade sem acesso à eletricidade, onde só existia um grupo gerador diesel que atendia a somente algumas das 87 famílias estudadas. O estudo foi baseado nos custos de financiamento a valor presente dos investimentos e pelo custo unitário da energia primária de geração versus a capacidade de compra das famílias. Os autores concluíram que a alternativa só seria viável a partir da redução dos custos dos investimentos projetados para alguns anos, onde os custos da geração seriam suportáveis para a comunidade local. Isto seria possível devido ao acréscimo do conforto e das possibilidades obtidas. Com o acesso à energia elétrica, a população local teria acesso a novas atividades econômicas, o que levaria a uma melhoria nas condições de vida e consequentemente, inclusão social.

Vanni (2008) fez um estudo de viabilidade econômica de fontes alternativas de energia para o estado do Maranhão, no Nordeste brasileiro. Para o estudo, a autora fez um levantamento bibliográfico a respeito das fontes eólica, solar e biomassa e também desenvolveu um banco de dados com as características do estado analisado. Foi criado, também, um programa para facilitar os cálculos, o Programa de Cálculo de Custos das Energias Alternativas Solar, Eólica e Biomassa (PEASEB). Para os cálculos, foi considerado um valor de custo ambiental padrão para todas as fontes, determinado como um acréscimo de $10 \%$ sobre o valor total do empreendimento. A partir dos cálculos desenvolvidos, a autora concluiu que a energia eólica e a biomassa apresentaram melhores resultados para aplicação nas comunidades analisadas.

Com base em alguns dos trabalhos apresentados, serão calculados os custos ambientais e a viabilidade econômica das fontes alternativas de energia solar, eólica e biomassa para pequenas comunidades do nordeste brasileiro.

Com a finalidade de fundamentar os cálculos realizados nesse trabalho, serão descritos, a seguir, os conceitos relacionados à economia e ao meio ambiente. 


\section{ECONOMIA E MEIO-AMBIENTE}

Existe uma relação muito estreita e direta entre as atividades econômicas e o meio ambiente. Todas as decisões tomadas pelos agentes de uma economia, consumidores e produtores afetarão, de alguma forma, e com alguma intensidade, o meio ambiente e a sociedade como um todo.

O rápido desenvolvimento tecnológico e econômico mundial, sem qualquer preocupação com o meio ambiente, trouxe graves consequências para os dias atuais, que podem ser agravadas ainda mais para as futuras gerações, caso medidas de contenção e controle de emissões, além da alocação de recursos, não sejam adotadas.

O consequente aumento da demanda e do consumo de energia advindos do avanço tecnológico e do desenvolvimento humano são fatores apontados como mais significativos na aceleração das alterações climáticas e ambientais, sendo observados e também descritos pela sociedade cientifica, já que o consumo de energia triplicou após a Revolução Industrial. Além disso, as tendências de crescimento apontam que o consumo de energia nos países em desenvolvimento, em virtude da melhoria de parâmetros socioeconômicos, ultrapassará o consumo dos países já desenvolvidos ainda na segunda década do século vigente (Pereira et al., 2006).

É possível haver desenvolvimento econômico com preservação do meio ambiente, desde que haja adequação dos mercados e adoção de políticas efetivas de proteção ao meio ambiente.

A seguir, serão abordadas as principais questões ligadas à economia e ao meio ambiente. Serão dadas as definições, diretrizes e conceitos da Economia Ambiental e suas origens.

\subsection{A economia e o meio ambiente: origens e o início dos debates}

$\mathrm{Na}$ economia clássica de autores como Adam Smith, a questão ambiental ainda não era objeto relevante de análise. Somente a partir de 1870, com economistas como Léon Walras e com a substituição da teoria do valor baseado no trabalho pela teoria do valor baseado na utilidade marginal, as questões ambientais começaram a ser discretamente discutidas e apareceram, 
efetivamente, a partir de 1890 com a Escola Neoclássica e com a publicação dos Princípios da Economia de Alfred Marshall. O trabalho publicado por Arthur Cecil Pigou, em 1920, intitulado "A Economia do bem-estar" pode ser citado como obra fundamental no debate ambiental, (Silveira, 2006).

Após a crise de 1929 e a aplicação do programa de recuperação conhecido como New Deal em 1933, aliado à publicação da obra de John Maynard Keynes em 1936, "A teoria geral do emprego, juros e moeda", a economia americana passou a sofrer maior intervenção estatal tendo como foco, o chamado welfare-state, estado de bem-estar social, ou keynesianismo. Contudo, correntes de pensamento econômico se opuseram ao keynesianismo e também às ideias neoliberais. Uma delas foi à chamada Economia Institucionalista, fundada pelo economista Thornstein Veblen. Os institucionalistas eram contrários à tendência de separação entre a economia e as outras ciências sociais (Silveira, 2006).

Segundo Silveira (2006), as divergências entre essas escolas econômicas levaram a uma discussão mais relevante acerca de questões como as alternativas de resolução/diminuição do impacto de externalidades no meio ambiente provocadas pelo crescimento ou pelo desenvolvimento econômico. Passou-se a debater, também, quando priorizar o crescimento econômico ou o meio ambiente, além dos debates sobre como deveria se dar a compensação à natureza com relação aos prejuízos gerados a ela pelos agentes econômicos, quer por intervenção governamental quer por livre negociação entre as partes.

É importante ressaltar também que as premissas neoclássicas voltaram com o trabalho de Coase (1960) e, mais recentemente, com os pressupostos do Consenso de Washington em 1990.

A seguir, são descritas as relações entre a atividade econômica e o meio ambiente, justificando o surgimento da Economia Ambiental, ramo da Ciência Econômica que dará amparo teórico a esse trabalho.

\subsection{Relação entre atividade econômica e meio ambiente}

Os recursos naturais são escassos e possuem usos alternativos. Por isso é necessário que seja feita uma alocação eficiente desses recursos, o que é um problema de natureza econômica. 
A relação entre as atividades econômicas e o meio ambiente é descrita por meio do Modelo do Balanço dos Materiais (FIG. 3.1), que mostra as conexões existentes entre as decisões econômicas e o ambiente natural. No modelo, é possível identificar dois fluxos: o Fluxo de Recursos, onde é descrito o fluxo dos recursos naturais do meio ambiente para a atividade econômica, que é objeto de estudo da Economia dos Recursos Naturais; e o Fluxo de Resíduos, que descreve o fluxo dos subprodutos ou resíduos que vão da atividade econômica (consumo e produção) para o meio ambiente. De acordo com o modelo, os problemas ambientais estão ligados ao funcionamento dos mercados de forma direta, já que todas as decisões dos agentes econômicos afetam a qualidade e a quantidade dos recursos. O Fluxo de Resíduos é o escopo dos estudos da Economia Ambiental (Thomas e Callan, 2010).

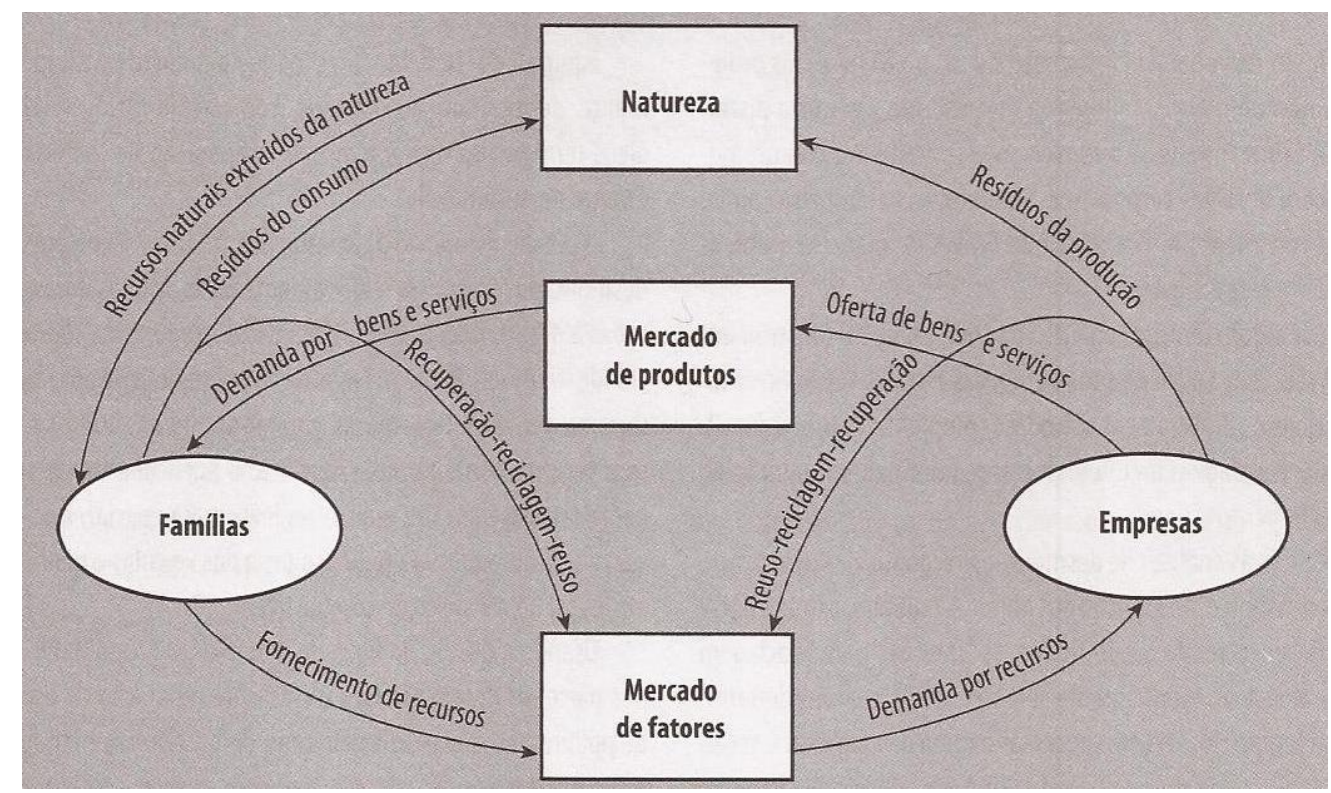

Fonte: Thomas e Callan, 2010 adaptado de Kneese, Ayres e D'Arge (1970).

FIGURA 3.1 - Modelo do Balanço de Materiais

\subsection{A Economia Ambiental}

Para Thomas e Callan (2010), a Economia Ambiental está preocupada em identificar e resolver o problema dos danos ambientais (ou da poluição) associados ao fluxo de resíduos e, ainda, essa área da economia busca utilizar modelos de falha de mercado para analisar o problema e identificar soluções. De acordo com os autores, identificar as causas, as fontes e o escopo dos danos é essencial para a sua resolução. Costa (2005) define a economia ambiental como 
"o campo da economia que aplica a teoria econômica às questões ligadas ao manejo e à preservação do meio ambiente."

A Economia Ambiental, difundida na década de 1980, era voltada às questões da poluição, percebida como uma externalidade dos processos produtivo e de consumo. Essa externalidade poderia ser tratada pela internalização dos custos ambientais nos preços dos produtos finais (Mattos e Mattos, 2004). Para esses autores, a Economia Ambiental pode ser associada aos trabalhos do economista Arthur Pigou, já mencionado na revisão da literatura dessa dissertação.

Uma melhoria na qualidade ambiental traz consigo uma melhoria econômica se aumentar a satisfação e o bem-estar social. Esse bem-estar precisa ser medido, e isso é feito pela Economia Ambiental, que busca mensurar os ganhos, como os benefícios advindos do progresso; as perdas, como os custos oriundos das reduções da qualidade ambiental para o bem-estar das populações (Pearce et. al., 1991).

\subsubsection{Classificação dos danos ambientais de acordo com a sua origem, fonte e extensão.}

A seguir, são descritos, de forma sucinta, os principais conceitos utilizados na Economia Ambiental referentes às causas, fontes e extensão dos danos ambientais.

Quanto à origem, os danos ambientais podem ser definidos como poluentes naturais, contaminantes originados em processos não artificiais da natureza; e poluentes antropogênicos, resultantes da ação humana (Thomas e Callan, 2010).

A fonte dos danos ambientais geralmente é dividida em dois grupos, caracterizados por sua mobilidade (estacionária ou móvel) e identificabilidade (pontual ou não pontual). A fonte estacionária possui uma fonte poluidora com localização fixa, como no caso das termelétricas a carvão. A fonte móvel trata de qualquer fonte de poluição não estacionária, como os automóveis. A fonte pontual caracteriza-se por fontes individuais de poluição, como chaminés. A fonte não pontual é uma fonte poluidora que não pode ser identificada de maneira clara (Thomas e Callan, 2010). 
Já a extensão dos danos ambientais, por ser variável, é classificada de acordo com o tamanho do impacto geográfico, como: local, regional ou global. A poluição local refere-se a danos ambientais que não se distanciam da fonte poluidora. A poluição regional é aquela que se distancia da fonte poluidora. A poluição global possui efeitos com implicações globais (Thomas e Callan, 2010).

\subsubsection{Fundamentos da Economia Ambiental}

A Economia Ambiental possui conceitos que são considerados fundamentais para o entendimento deste ramo da economia (Costa, 2005). São eles:

1 - Critério de Pareto

2 - Externalidades

3 - Taxa Pigouviana

4 - Teorema de Coase

Cada conceito será descrito mais detalhadamente a seguir.

\subsubsection{Critério de Pareto}

O economista italiano Vilfredo Pareto foi um dos primeiros estudiosos a examinar as implicações do conceito de eficiência. A Eficiência de Pareto (ou Eficiência Econômica) é um critério da microeconomia muito útil para comparar os resultados de diferentes instituições econômicas, podendo ser utilizado para avaliar diferentes formas de alocação de recursos. Uma situação econômica é eficiente no sentido de Pareto se não existir nenhuma forma de melhorar a situação de um grupo sem piorar a de outro (Varian, 2006).

$\mathrm{Na}$ economia ambiental o também chamado Critério de Pareto é utilizado para julgar se a alocação dos recursos é eficiente. Esta resposta estabelecerá um ponto ótimo que servirá como base para as negociações entre o setor público e privado, para a preservação do meio ambiente, e será de grande importância para estabelecer um ponto de equilíbrio entre a produção e a poluição, que é a mais importante falha de mercado na área ambiental (Costa, 2005).

O nível ótimo aqui se dará quando os produtores limitarem a produção a níveis economicamente viáveis, que satisfaçam às condições definidas pela sociedade dos níveis de poluição aceitáveis por ela (Costa, 2005). 


\subsubsection{Externalidades}

O primeiro teorema da Teoria Econômica do Bem-Estar mostra que, na falta de externalidades, um mercado livre e competitivo proporciona resultados eficientes. Contudo, existindo externalidades, o resultado do mercado competitivo não será eficiente no sentido de Pareto (Varian, 2006).

Segundo Mankiw (2011), as externalidades que são uma falha de mercado surgem "quando uma pessoa se dedica a uma ação que provoca impacto no bem-estar de um terceiro que não participa dessa ação, sem pagar nem receber nenhuma compensação por esse impacto". Se o impacto gerado for adverso é chamado de externalidade negativa; se for benéfico, externalidade positiva. O equilíbrio de mercado não é eficiente quando existem externalidades, pois o equilíbrio não maximiza o beneficio total para a sociedade. As externalidades levam os mercados a alocar os recursos de forma ineficiente (Mankiw, 2011). Os problemas práticos referentes às externalidades geralmente surgem por conta da má definição dos direitos de propriedade (Varian, 2006).

A externalidade é um fenômeno que pode ocorrer entre os consumidores, firmas e entre combinações de ambos. Costa (2005) afirma que a compreensão do conceito de externalidade demonstra a ideia que a sociedade faz dos recursos naturais. Por usufruir desses bens de forma gratuita, a sociedade não atribui o valor correto a eles.

Segundo Varian (2006), as soluções para as externalidades incluem a utilização das taxas de Pigou, o estabelecimento de mercados para as externalidades, além de transferências de direitos de propriedade, já que a troca entre os agentes resultaria na alocação eficiente da externalidade. O Estado deve assegurar a boa definição dos direitos de propriedade para que as trocas geradoras de eficiência possam ocorrer.

\subsubsection{Taxa Pigouviana}

"As externalidades negativas fazem com que os mercados produzam uma quantidade maior do que a socialmente desejável. As externalidades positivas fazem com que os mercados produzam uma quantidade menor do que a socialmente desejável. Para solucionar esse problema, o governo pode internalizar a externalidade tributando bens que carreguem externalidades negativas e subsidiando os bens que trazem externalidades positivas (Mankiw, 2011, p. 199)." 
A Taxa Pigouviana, originada do trabalho do Economista Arthur Cecil Pigou, The Economics of Welfare (1920), estabeleceu as diferenças entre os custos marginais privados e sociais. Além disso, defende a intervenção do Estado por meio da tributação para corrigir falhas de mercado e internalizar externalidades, fazendo com que os custos marginais do produtor sejam incorporados aos seus custos e não repassados para a sociedade de forma indiscriminada. Assim, o valor da taxa a ser recolhida pelo poluidor sobre a unidade de poluição emitida deveria ser igual ao custo marginal social das emissões.

Trata-se de uma política de caráter econômico para os controles dos níveis de poluição pela imposição de taxas sobre a emissão de poluentes. $O$ valor dessa taxa deve ser igual ao custo marginal social da poluição em seu nível ótimo de emissão sobre a unidade de poluição emitida, ou seja, a aplicação da taxa sugerida por Pigou igualaria o custo marginal imposto à sociedade, passando o fabricante a assumir o total dos custos de produção. (Costa, 2005).

Então, para Costa (2005) a Taxa Pigouviana atinge seu objetivo de redução dos níveis de poluição, minimizando os custos para a sociedade e, além disso, estimula a busca de tecnologias menos poluentes por parte do setor produtivo, que buscará o não aumento de custos.

\subsubsection{Teorema de Coase}

Ronald H. Coase, em 1960, publicou o trabalho "The problem of social cost”, que contraria as ideias de Pigou, amplamente adotadas na época, onde os custos sociais eram originados por falhas de mercado e deviam ser corrigidos pelo Estado por meio de medidas impostas aos causadores do impacto. Para Coase (1960), a o problema das externalidades tinha origem na indefinição dos direitos de propriedade e na ausência de mercados que possibilitassem a internalização dos custos. A solução deveria ser pensada a partir da natureza recíproca do problema, com direitos de propriedade bem definidos já que, a partir dessa definição e, desde que haja uma negociação sem custos de transação entre as partes, as externalidades podem ser corrigidas.

O Teorema de Coase propõe a negociação entre os agentes que poluem e os que sofrem seus efeitos, a fim de chegar a um ponto ótimo pelo Critério de Pareto. Então, se os agentes econômicos puderem negociar sem 
custos de transação (custos que as partes incorrem no processo de negociação) a alocação de recursos e, desde que os direitos de propriedade sejam bem definidos, eles poderão solucionar o problema das externalidades de uma forma eficiente. A livre negociação entre as partes deve levar as externalidades ao nível ótimo (Costa, 2005; Mankiw, 2011).

Mas, para que ocorressem essas negociações, seriam necessários, por exemplo, mercados para negociar as externalidades, como, por exemplo, a poluição. E, segundo Costa (2005) um dos maiores obstáculos para a implementação desses mercados é que os agentes consideram os recursos naturais como bens públicos, gratuitos e infinitos, de direito de todos e de responsabilidade do Estado. A seguir serão definidos os bens públicos para melhor entendimento desse aspecto.

\subsection{Os bens públicos}

Os bens públicos, de acordo com Mankiw (2011), são os bens que não são excludentes, que ninguém pode ser impedido de usar e que não são rivais, ou seja, sua utilização não impede que outro também o faça.

Varian (2006) define os bens públicos com "aqueles dos quais toda pessoa tem que consumir a mesma quantidade, como a poluição do ar".

O meio ambiente é um bem de uso comum do povo, além de ser um bem público que deve ser utilizado e também preservado por toda a sociedade (Costa, 2005).

Para que a provisão de um bem público seja eficiente no sentido de Pareto, a soma da propensão a pagar, ou preços de reserva, devem exceder os custos do bem (Varian, 2006). É possível produzir bens públicos de forma eficiente, mas como os indivíduos desconhecem o valor desses bens, acabam subestimando seu valor e utilizando além do necessário, sem qualquer preocupação em limitar seu consumo, o que leva à produção ineficiente desses bens (Costa, 2005).

$\mathrm{Na}$ economia, o uso inadequado e excessivo dos recursos de propriedade comum é chamado de "A tragédia dos comuns", termo originado em um trabalho publicado, em 1968, pelo biólogo Garret Gardin, onde ele determinou que a causa da maioria dos problemas ambientais é a utilização inadequada dos recursos comuns. Como os recursos ambientais não possuem propriedade 
definida e não há cobranças pelo seu uso, a tendência é sua utilização até o limite de escassez (Costa, 2005).

Então, o maior problema dos bens públicos é a atribuição de valores diferentes que cada um lhes dá, causando a produção ineficiente desses bens. Essa produção será escassa para quem atribui maior valor e excedente para quem Ihes atribui menor valor, causando seu consumo excessivo por conta do comportamento free rider, onde os agentes econômicos se beneficiam de bens ou serviços enquanto esses forem gratuitos (Costa, 2005).

\subsection{A economia do bem-estar e sua ligação com o a Economia Ambiental}

A economia do bem-estar é o estudo de como a alocação de recursos afeta o bem-estar econômico. O bem-estar das pessoas é medido por todas as suas formas de consumo e também de amenidades de origens recreacionais, políticas, culturais e também ambientais. No caso dos investimentos públicos que têm por objetivo a provisão de bens e serviços que visam o aumento do bemestar das pessoas, as decisões governamentais de uso desses recursos podem ser auxiliadas por uma análise social de custo-benefício, que atribui uma valoração social a todos os efeitos de um determinado projeto, investimento ou política (Motta, 1998).

A definição dessa valoração social é a incorporação dos efeitos positivos, como benefícios, e dos negativos, como custos. E, para que seja possível uma comparação, torna-se necessária a expressão desses efeitos em uma unidade comum, como a monetária (Motta, 1998).

Da determinação dos custos e benefícios sociais, base da teoria microeconômica do bem-estar, derivam os métodos de valoração monetária dos recursos ambientais, em que a análise de custo-benefício considera também os valores sociais dos bens e serviços, refletindo desta forma as variações de bemestar e não somente valores de mercado (Motta, 1998).

\subsection{A importância da valoração ambiental}

Para que haja uma melhor alocação dos recursos ambientais, é importante que se faça uma avaliação econômica adequada dos bens e serviços ambientais. As estimativas monetárias são um instrumento dessa medição, já que o dinheiro é uma unidade de medida conveniente. Quando, por algum motivo, 
não se consegue fazer uso do dinheiro para a valoração, as escolhas devem ser feitas em contextos de recursos escassos (Pearce et. al., 1991).

Estimar o quanto vale o meio ambiente incluindo esses valores na análise econômica é uma forma de tentar corrigir as tendências negativas do livre mercado (Mattos e Mattos, 2004).

As abordagens para a mensuração econômica dos benefícios ambientais podem ser classificadas como técnicas diretas e indiretas. A primeira considera os ganhos ambientais medindo o valor monetário desses ganhos por intermédio de um mercado substituto ou pelo uso de técnicas experimentais. Os procedimentos indiretos calculam relações dose-resposta como, por exemplo, estimar a relação entre a "dose" (poluição) e os efeitos não monetários "resposta" (problemas de saúde). Algumas melhorias ambientais podem aparecer na forma de efeitos que possuem valores monetários diretos, como, por exemplo, reduções nas emissões de enxofre que reduziriam a corrosão metálica das edificações, reduzindo o custo de manutenção ou substituição das partes metálicas. As melhorias na saúde humana podem aparecer, por exemplo, na redução da busca por serviços médicos decorrente de menos problemas respiratórios que resultaram da redução de emissões de gases poluentes. Esses exemplos mostram algumas das formas de avaliação monetária dos ganhos de bem-estar advindos de melhorias ambientais. No entanto, alguns ganhos podem aparecer de forma indireta. Em casos onde não existam mercados aparentes, ainda há a preferência pelo ganho ambiental que precisa ser medida (Pearce et. al., 1991).

As preferências para as melhorias ambientais podem aparecer de várias maneiras. De forma mais simples, o que se busca é saber quanto as pessoas estariam dispostas a pagar para preservar ou melhorar o meio ambiente, ou ainda, a vontade dos indivíduos de aceitarem a perda. Essas medidas irão expressar não apenas a preferência, mas também a intensidade dela. Pode-se dizer que as medidas monetárias se tornam um forte argumento na defesa da qualidade ambiental (Pearce et. al., 1991).

A quantificação monetária permite também a comparação dos ganhos/perdas ambientais com outros benefícios monetários decorrentes do uso alternativo dos recursos. Então, nesse caso, a melhor opção é a que traz o melhor benefício líquido, ou seja, mais benefícios sobre os custos sem prejuízo a outras considerações, como o interesse das gerações futuras (Pearce et. al., 1991). A 
internalização dos custos ambientais é uma fase importante, que tem o intuito de controlar o uso dos recursos e serviços naturais. $O$ consumidor pagaria o custo real do que estiver consumindo (Mattos e Mattos, 2004).

Essa comparação entre os custos e benefícios de duas ou mais opções é conhecida como Análise Custo-Benefício, onde as decisões devem ser baseadas em algumas ponderações das vantagens e desvantagens de uma ação. Essa abordagem tem o dinheiro como ferramenta de medição, (Pearce et. al., 1991).

Segundo Motta (1998), a análise custo-benefício (ACB) é a ferramenta econômica mais utilizada na determinação de prioridades, quando se avaliam políticas a serem implementadas com o objetivo de comparar os custos (o bemestar que se deixou de ter em função da alternativa escolhida) e benefícios (impacto positivo no bem-estar) das alternativas disponíveis em termos monetários. A partir dessa análise, o gestor pode adotar a política que maximize a utilização dos recursos disponíveis otimizando, dessa forma, o bem-estar social.

A importância dos métodos de valoração ambiental vai além do dimensionamento dos impactos ambientais e sua internalização, pois evidencia os custos e benefícios da expansão das atividades humanas no meio ambiente (Mattos e Mattos, 2004).

Motta (1998) afirma que,

“...é válido mencionar que a valoração de alguns benefícios de um dado investimento em biodiversidade pode ser suficiente para demonstrar que estes benefícios, mesmo subvalorizados, já estão excedendo os custos. Apesar disto não ser suficiente para assegurar que a sociedade está adotando a melhor alternativa de uso de seus recursos econômicos, os tomadores de decisão podem, pelo menos, garantir que a eficiência econômica não decrescerá em função desse investimento ambiental (Motta, 1998 p. 19)".

Segundo Mattos e Mattos (2004), os métodos de valoração ambiental são importantes não só pela necessidade de dimensionamento dos impactos ambientais, internalizando-os à atividade econômica, mas também, para tornar evidentes os custos e benefícios decorrentes das atividades humanas na economia.

Assim, a valoração econômica dos recursos ambientais será abordada mais detalhadamente no capítulo a seguir, a fim de ser utilizada como ferramenta para a obtenção dos custos ambientais das fontes de energia analisadas neste trabalho. 


\section{METODOLOGIA PARA OS CÁLCULOS DOS CUSTOS AMBIENTAIS}

O modelo de fornecimento de energia elétrica brasileiro é baseado na geração de grandes blocos de energia, conectados à rede de distribuição. Esse modelo torna regiões de baixa densidade populacional e povoamento esparso, como é o caso de algumas localidades da região Nordeste brasileira, áreas com baixos índices de eletrificação, já que é economicamente inviável levar a rede convencional a essas regiões. Por conta disso, a eletrificação nessas regiões remotas baseia-se basicamente em sistemas isolados com geradores diesel, pouco eficientes, de custo elevado e com alto custo ambiental. O óleo diesel é a principal fonte energética utilizada nas comunidades não eletrificadas (Coelho et al., 2005). Por isso ele será a fonte base a ser considerada para as análises dos custos ambientais que serão devidamente explicados nesse capítulo.

O processo de poluição atmosférica começa com a emissão de poluentes primários por fontes naturais ou é provocado pela atividade humana. À medida que poluentes são transportados pelo ar, combinações entre eles ocorrem formando poluentes secundários. Os principais poluentes do ar podem ser classificados em: compostos de enxofre, nitrogênio e halogenados, compostos de carbono (monóxido e dióxido de carbono) e material particulado (Motta e Mendes, 1995).

Motta e Mendes (1995) definem a poluição do ar como:

"a presença de um ou mais contaminantes na natureza, em quantidades que podem comprometer a qualidade deste recurso, tornando-o impróprio, nocivo ou ofensivo à saúde, inconveniente ao bem estar público, danoso aos materiais, à fauna e à flora ou prejudicial à segurança, ao uso e gozo da propriedade e às atividades normais da comunidade (Motta e Mendes, 1995, p. 166)."

Nesse capítulo são fornecidas as bases para os cálculos das externalidades que terá como foco a poluição atmosférica causada por geradores diesel na região estudada em comparação com as fontes eólica, solar e biomassa. Também serão descritas a Valoração Econômica dos Recursos Ambientais (VERA) e a forma adotada nesse trabalho para o seu cálculo.

\subsection{A valoração econômica dos recursos ambientais (VERA)}

O valor econômico dos recursos ambientais é originado a partir de todos os seus atributos que podem ou não estar associados a algum uso. Então, 
pode-se dizer que a Valoração Econômica dos Recursos Ambientais (VERA) é determinada por (Motta, 1998):

- valores de uso (VU), composto por valor de uso direto (VUD), valor de uso indireto (VUI) e valor de opção (VO);

- valor de não-uso (VNU), que representa o valor de existência do bem (VE).

Então, Motta (1998) define o VERA com a equação (4.1):

$V E R A=(V U D+V U I+V O)+V E$

Onde, de acordo com Motta (1998) e Mattos e Mattos (2004):

- Valor de uso direto (VUD): determinado pela contribuição direta do recurso ambiental no processo de produção e consumo. É o recurso que pode ser consumido ou utilizado diretamente, como a biomassa, alimentos ou atividades de produção ou consumo diretos;

- Valor de uso indireto (VUI): mede os benefícios derivados dos serviços proporcionados pelo meio ambiente para o suporte dos processos produtivos e de consumo, apoiando as atividades econômicas e de bem-estar da sociedade. Trata-se de benefícios, tais como funções ecológicas, manutenção da diversidade e prevenção de erosão;

- Valor de opção (VO): valor que os consumidores estão dispostos a pagar por um recurso natural que não faz parte dos processos produtivos para evitar sua extinção. Está baseado em quanto as pessoas estão dispostas a pagar pela opção de preservação de um dado bem ou recurso para uso futuro como, por exemplo, a biodiversidade ou as propriedades medicinais de plantas ainda não descobertas.

- Valor passivo ou valor de existência (VE): é um valor atribuído à existência do meio ambiente, independentemente de seu uso como, por exemplo, o de espécies em extinção. Relaciona-se à preservação, à existência de espécies e riquezas naturais. 
Para encontrar o VERA, vários métodos são possíveis. Todos os métodos para a valoração ambiental possuem limitações, e a adoção de um método dependerá do objetivo da valoração, das hipóteses assumidas, da disponibilidade dos dados e da dinâmica do bem valorado (Motta, 1998).

Mattos e Mattos (2004) categorizam os métodos de valoração ambiental em métodos diretos, relacionados aos preços de mercado e à produtividade, tendo como base as relações físicas de causa e efeito, além de métodos indiretos, aplicados quando a valoração não pode ser feita pelo comportamento do mercado.

Em casos onde os efeitos ambientais são localizados ou específicos é possível medir seus impactos negativos de forma direta, como a perda de energia gerada pela queima da cana-de-açúcar, que pode ser medida pela produção perdida, como foi feito no trabalho de Mattos e Mattos (2004).

No trabalho de Motta (1998), uma forma de obtenção do VERA, demonstrada por um estudo de caso, utilizou o Método dos Custos Evitados. Nesse caso, os métodos de investigação revelaram apenas valores de uso, e foi possível constatar que o VU foi suficiente para viabilizar os investimentos previstos. A seguir, será descrita a metodologia adotada nesse trabalho para a obtenção do VERA.

\subsection{Metodologia para a obtenção do VERA e dos custos ambientais das fontes alternativas de energia}

Nesse estudo será feita uma análise dos custos evitados ao meio ambiente pela substituição de geradores de eletricidade movidos a óleo diesel por fontes alternativas de energia (solar, eólica e biomassa).

Inicialmente serão descritas as emissões de gases poluentes ao meio ambiente, originadas pelos geradores diesel quando da produção de eletricidade. Esses valores serão convertidos para valores monetários para encontrar o VERA do ar poluído por essa fonte, então serão comparados com os cálculos do VERA para as fontes alternativas de energia aqui estudadas (solar, biomassa e eólica).

O custo ambiental será obtido subtraindo-se o valor encontrado para a fonte alternativa analisada do valor encontrado para o VERA do ar poluído pelo diesel. Se o valor calculado for negativo, o impacto dessa fonte alternativa é benéfico, ou seja, se trata de uma externalidade positiva. Caso o valor desse 
cálculo seja positivo, o impacto dessa fonte será adverso, ou seja, se trata de uma externalidade negativa.

Inicialmente, será feita uma análise sobre as emissões de gases de efeito estufa, as emissões geradas pelo óleo diesel, as possibilidades do mecanismo de desenvolvimento limpo (MDL) e a venda de Certificados de Redução de Emissões (CER's). Esses dados são necessários para a obtenção do VERA pela metodologia aqui adotada.

\subsection{Análise das emissões de Gases de Efeito Estufa (GEE)}

Alvim et al. (2010) avaliaram as emissões de Gases de Efeito Estufa (GEE) em toneladas equivalentes de $\mathrm{CO}_{2}$ por unidade de energia elétrica (MWh) de diversas fontes de energia com o intuito de compará-las. Os autores adotam como metodologia de avaliação das emissões no ciclo de geração de eletricidade, um processo de aproximações sucessivas para emissões diretas e indiretas para todas as fases da produção de eletricidade. Para essa dissertação, serão consideradas apenas as emissões da fase de geração de eletricidade, que consideram as emissões diretas da produção, que serão descritas a seguir.

As emissões indiretas são aquelas que se relacionam com a fabricação de equipamentos e obtenção de insumos, fora do ciclo ou das instalações. As emissões diretas na geração de eletricidade são aquelas que resultam da utilização do combustível e englobam: o $\mathrm{CO}_{2}$ (dióxido de carbono), $\mathrm{CH}_{4}$ (metano), NMVOCs (compostos orgânicos voláteis com exceção do metano), CO (carbono) e $\mathrm{N}_{2} \mathrm{O}$ (óxido nitroso). As emissões são convertidas em $\mathrm{CO}_{2}$ equivalente seguindo o critério adotado pelo Global Warming Potential (GWP) (Alvim et al., 2010).

O critério utilizado pelo GWP (ou Potenciais de Aquecimento Global), criado pelo IPCC em 1990, e adotado para utilização no Protocolo de Quioto, considera a conversão da emissão de um pulso de $1 \mathrm{~kg}$ de algum composto a $1 \mathrm{~kg}$

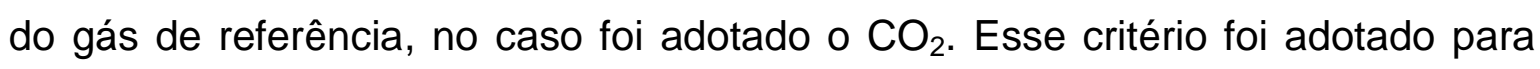
corrigir algumas dificuldades encontradas na definição de uma métrica geral de emissões (Solomon et al., 2007).

Os cálculos das emissões feitos por Alvim et al. (2010) foram apurados a partir de dados do Balanço Energético Nacional (BEN) e, também a partir da utilização de dados internacionais adaptados, quando possível, para a realidade 
brasileira. Os coeficientes de emissão utilizados por esses autores foram preferencialmente os utilizados no Inventário Brasileiro de Emissões.

$\mathrm{Na}$ TAB. 4.1 são apresentadas as emissões referentes à fase de geração de eletricidade, estimadas para algumas fontes de energia. As emissões são apresentadas em $\mathrm{gCO}_{2} \mathrm{eq} / \mathrm{kWh}$ el, equivalente a $\mathrm{tCO}_{2} \mathrm{eq} / \mathrm{GWh}_{\mathrm{el}}$.

TABELA 4.1 - Emissões referentes à fase de geração de eletricidade

\begin{tabular}{c|c}
\hline Fonte de energia & $\begin{array}{c}\text { Emissões totais na fase de geração } \\
\left(\mathbf{g C O}_{\mathbf{2}} \mathbf{e q} / \mathbf{k W h} \mathbf{h}_{\mathrm{EI}}\right)\end{array}$ \\
\hline Óleo Diesel & 755 \\
Óleo Combustível & 725 \\
Carvão & 1262 \\
Gás Natural & 465 \\
Nuclear & 0,8 \\
Eólica & 5,4 \\
Fotovoltaica & 0 \\
\hline
\end{tabular}

Fonte: Alvim et al. (2010).

De acordo com a TAB 4.1, o óleo diesel é a segunda fonte mais poluidora em termos de emissões de GEE para a atmosfera, perdendo apenas para o carvão. Essa fonte emite $755 \mathrm{gCO}_{2} \mathrm{eq} / \mathrm{kWh}_{\mathrm{El}}$, que é um valor alto e de grande impacto para o meio ambiente, principalmente quando comparado a fontes alternativas como a solar fotovoltaica, de emissão zero.

Os valores dessa tabela servirão como base para os cálculos do VERA desse trabalho.

\subsection{O mecanismo de desenvolvimento limpo (MDL) e sua contribuição para} a análise dos custos ambientais

No Protocolo de Quioto, firmado em 1997, no Japão, os países desenvolvidos comprometeram-se a limitar ou reduzir suas emissões antrópicas. Exclui-se desse tratado os Estados Unidos, que promulgaram uma resolução no mesmo ano definindo a sua não adesão a protocolos ou compromissos de redução de emissões, a não ser que esses compromissos também fossem impostos aos países em desenvolvimento (Silva et al., 2000).

O Mecanismo de Desenvolvimento Limpo (MDL), presente no protocolo 
de Quioto, possibilita a captação de recursos internacionais para projetos que possam colaborar para a redução dos impactos ambientais causados pelo efeito estufa. O MDL é um mecanismo que consiste na certificação de projetos de redução de emissões e sequestro de carbono em países em desenvolvimento, bem como na venda desses certificados para países desenvolvidos, a fim de que os países atinjam suas metas de redução de emissões. Os países em desenvolvimento que implementarem o MDL emitirão Certificados de Redução das Emissões (CER, do inglês Certified Emission Reduction) que serão utilizados pelos países desenvolvidos para cumprirem suas metas de redução das emissões, acordadas no Protocolo de Quioto (Silva et al., 2000). Os projetos de MDL só serão considerados se as emissões antropogênicas de GEE forem menores do que as emissões que ocorreriam no caso da não existência do projeto inserido no MDL, ou ainda, se o sequestro de carbono com a implementação do projeto fosse maior do que sem ele (IPEA, 2011).

Então, para cada unidade métrica de carbono reduzida por meio do projeto inserido no MDL, será creditado um crédito de carbono (CER) a ser comercializado (IPEA, 2011). A unidade de carbono será calculada conforme metodologia GWP já descrita anteriormente, onde é feita a uniformização dos diferentes GEE em termos de $\mathrm{CO}_{2}$ equivalente.

Pela intensificação desse mercado, o Banco Mundial (BIRD) criou um fundo para as transações envolvendo créditos de carbono em um montante de US\$150 milhões. Silva et al. (2000) afirmam que, no Brasil, existem expectativas de novos mercados e instrumentos financeiros que viabilizem essas transações.

Segundo o IPEA (2011), o intervalo de variação dos preços para a redução de emissões é muito elevado. Este intervalo de variação para o preço do carbono no mercado de MDL, por meio da utilização dos CER's, está entre US\$ 3,00 e US\$ 7,00. Devido a esta variação nos preços, nesta dissertação será adotado o valor médio entre o mínimo e máximo praticado no mercado, ou seja, US\$ 5,00 por tonelada de $\mathrm{CO}_{2}$ equivalente.

Os cálculos serão demonstrados em reais $(R \$)$ neste trabalho. Para isso, o valor médio de comercialização das CER's será convertido de dólares para reais. Será utilizada a cotação do dólar americano (US\$) de fechamento da PTAX 
dada pelo Banco Central do Brasil ${ }^{1}$, que é dada pela média aritmética das taxas de compra e venda dos boletins do dia. Será adotada a taxa de fechamento do dia 10/09/2013 no valor de $\mathrm{R} \$ 2,2779$ (cotação de venda).

Observa-se, então, que a comercialização dos CER na substituição de fontes fósseis por fontes alternativas de energia podem contribuir de forma positiva nos estudos de viabilidade destas fontes.

Para os estudos de viabilidade aqui apresentados, serão considerados, para a avaliação de externalidades e custos ambientais, a possibilidade da venda de créditos de carbono. O mercado internacional de créditos de sequestro ou redução de emissões de carbono tem como expectativa chegar a montantes em torno de US\$20 bilhões ao ano em todo o mundo.

A partir dessas informações é possível calcular o VERA do ar poluído pelos GEE, a partir das emissões de vários combustíveis e, desta forma, obter os custos evitados pela substituição destas fontes por outras menos poluentes.

Então, será calculado o VERA do ar poluído pelos GEE a partir das emissões do óleo diesel e, desta forma, será obtido o custo evitado pela substituição desta fonte por outras menos poluentes: solar, biomassa e eólica para todos os municípios da região nordeste do país, com população entre 1.000 e 10.000 habitantes. Para isso, um banco de dados foi desenvolvido, considerando os dados referentes aos municípios analisados, englobando o número de habitantes, densidade populacional do município, extensão territorial e o número de famílias estimadas com 5 pessoas no município, em média. Os dados foram obtidos junto ao IBGE (2013).

\footnotetext{
${ }^{1}$ http://www4.bcb.gov.br/pec/taxas/port/ptaxnpesq.asp?id=txcotacao
} 


\section{METODOLOGIA DE CÁLCULO DE VIABILIDADE ECONÔMICA PARA ENERGIA SOLAR FOTOVOLTAICA}

Os conceitos de avaliação financeira e avaliação econômica são bem distintos dentro da ciência econômica, sendo a distinção mais objetiva a ótica pela qual são feitas as avaliações.

A avaliação financeira, desenvolvida sob o ponto de vista privado, compara benefícios privados diretos de um projeto com seus custos monetários diretos, utilizando instrumentos financeiros, sintetizando receitas e custos esperados, e enfatizando uma maior rentabilidade possível (Vital et al., 2011).

$\mathrm{Na}$ avaliação econômica, tem-se uma visão pública da formulação de políticas de interesse nacional, levando em consideração na análise os efeitos indiretos e as externalidades. $\mathrm{Na}$ análise econômica as externalidades positivas são incorporadas aos benefícios e, as negativas, aos seus custos. Os instrumentos de análise econômica estão baseados na Economia do Bem-Estar (Vital et al., 2011).

A partir desta conceituação, são desenvolvidos os cálculos de viabilidade econômica das fontes alternativas de energia aqui estudadas: solar, biomassa e eólica. Inicialmente, será feita uma breve descrição das normas que regem a gratuidade no fornecimento de energia. O dimensionamento de todos os sistemas foram feitos respeitando os limites impostos nas normas descritas a seguir.

\subsection{Definições gerais para os sistemas}

Todos os sistemas serão projetados visando atender ao disposto nas normas ANEEL 83/2004 SIGFI para sistemas individuais (ANEEL, 2004) e ANEEL 493/2012 MIGDI (ANEEL, 2012), para minirredes. Este procedimento foi adotado para enquadrar o trabalho ao Programa Luz para Todos, que prevê gratuidade do fornecimento de energia de até $80 \mathrm{kWh}$ por residência.

A Resolução Normativa ANEEL 83/2004 estabelece os procedimentos e condições do fornecimento de energia por meio de Sistemas Individuais de Geração de Energia Elétrica com Fontes Intermitentes (SIGFI) e a Resolução Normativa ANEEL 493/2012 estabelece os procedimentos e condições de 
fornecimento de energia a partir de Microssistema Isolado de Geração e Distribuição de Energia Elétrica (MIGDI) ou SIGFI (ANEEL, 2004 e 2012).

De acordo com a norma da ANEEL 83/2004 (ANEEL, 2004) para a implementação do programa Luz para Todos serão consideradas para o atendimento ao público alvo "tanto a extensão de redes convencionais, como sistemas de geração descentralizados, com redes isoladas ou sistemas individuais" para a universalização dos serviços de energia elétrica e suas características exigem uma regulamentação especifica.

Os sistemas implementados devem estar enquadrados em uma das classes de atendimento explicitadas nas normas citadas, que variam de uma disponibilidade mensal garantida entre 13 e $80 \mathrm{kWh} / \mathrm{mês}$ para cada unidade consumidora. A disponibilidade mensal garantida é a quantidade mínima de energia que o SIGFI/MIGDI é capaz de fornecer à unidade consumidora em qualquer mês. Além disso, a geração de energia se dará a partir de fontes de energia intermitentes, recursos energéticos renováveis que não podem ser armazenados em sua forma original, para fins de conversão em energia elétrica.

Então, o SIGFI é o sistema de geração de energia elétrica, implantado que utiliza exclusivamente fontes de energia intermitentes. Este sistema fornece energia para uma única unidade consumidora e é constituído por um sistema de geração, que converte a energia primária em energia elétrica, um sistema de acumulação, que acumula a energia gerada para uso em momentos de indisponibilidade ou insuficiência da fonte, e um sistema condicionador, ou sistemas de conversão.

O MIGDI é um microssistema isolado de geração e distribuição de energia elétrica com potência instalada total de geração de até $100 \mathrm{~kW}$.

Os sistemas (SIGFI ou MIGDI) devem ser instalados pela distribuidora de energia.

A partir destas informações, os sistemas foram dimensionados para atender a legislação vigente e assim enquadrar a pesquisa na gratuidade do fornecimento de eletricidade. A seguir serão detalhados os sistemas de geração solar com as suas respectivas características, tecnologias, custos e cálculos de viabilidade.

Assim, os cálculos de viabilidade econômica da energia solar fotovoltaica seguem as normas descritas. Todos os sistemas serão projetados 
visando atender ao disposto nas normas e terão internalizados os custos ambientais gerados e calculados pelo método dos custos evitados pela substituição de geradores diesel pela fonte analisada.

Para a energia solar fotovoltaica, foram considerados sistemas em minirredes e também sistemas isolados.

\subsection{Energia solar fotovoltaica}

A geração de energia fotovoltaica (FV) é a conversão direta da luz solar em eletricidade. Em diversas áreas mais remotas, os sistemas autônomos de energia FV são as únicas formas de geração de eletricidade viáveis. As células solares apresentam pouca ou nenhuma poluição associadas ao seu uso e possuem montagem rápida, cerca de 1-2 anos (Hinrichs e Kleinbach, 2003).

Atualmente, a maior parte das células em uso é feita de monocristal de silício. Células solares individuais são eletricamente conectadas a placas planas e estes arranjos fornecem $47 \mathrm{~W}$ a $12 \mathrm{~V}$ sob insolação plena. Em escalas menores, células individuais podem ser conectadas em série ou paralelamente. A saída é em corrente continua (CC) e seu armazenamento pode ser feito por meio de baterias, sendo necessário um estabilizador para evitar sobrecargas e um inversor, para demandas de corrente alternada (CA) (Hinrichs e Kleinbach, 2003). A FIG. 5.1 exemplifica uma instalação residencial fotovoltaica.

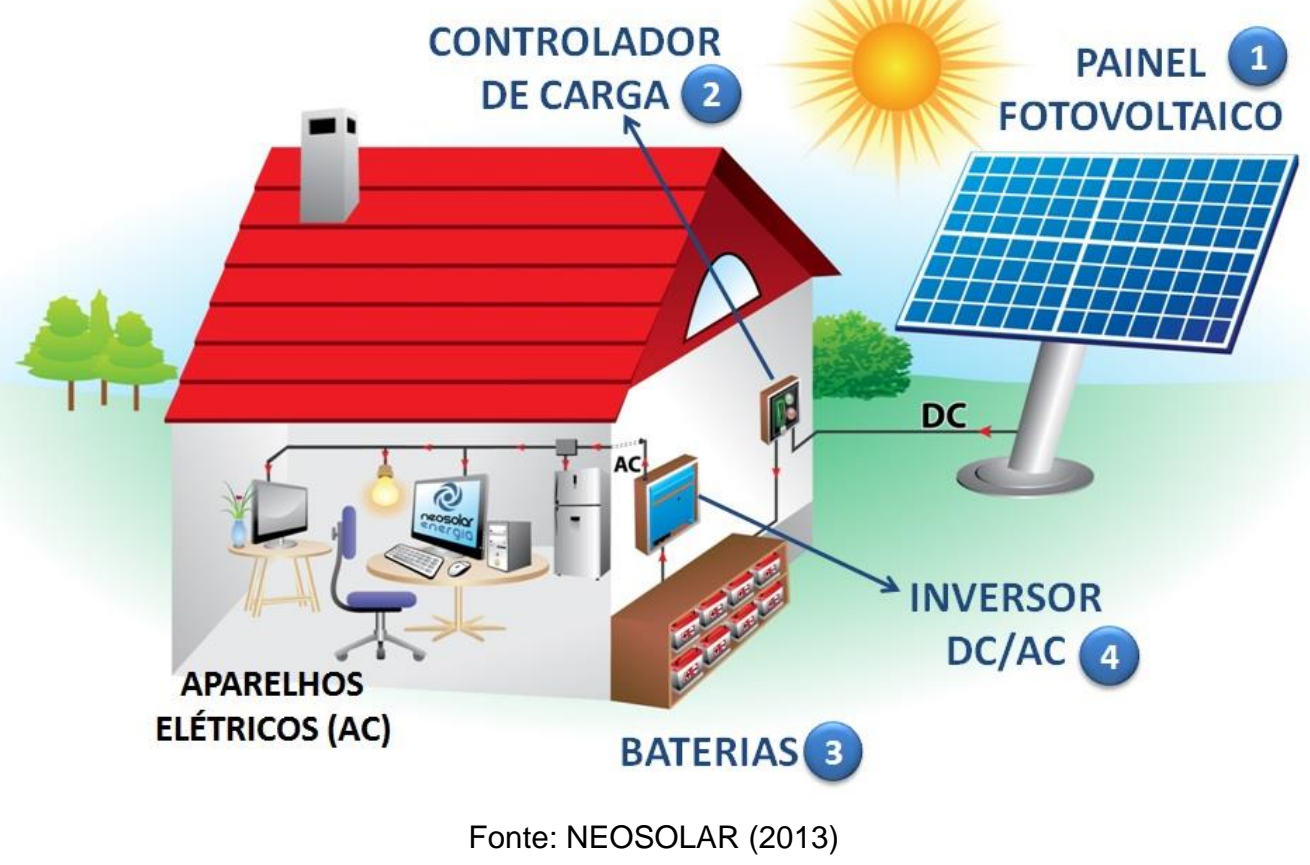

FIGURA 5.1 - Sistema FV residencial 
A utilização da energia solar, segundo Pereira et. al. (2006), traria vários benefícios em longo prazo. Ela viabilizaria o desenvolvimento de regiões remotas do país, onde os custos de uma rede convencional seriam muito altos e regularia a oferta de energia nos períodos de estiagem. Além disso, reduziria a dependência de combustíveis fósseis, contribuindo para a redução da emissão de poluentes oriundos da geração de energia.

O aproveitamento da energia solar abrange desde pequenos sistemas isolados autônomos até grandes centrais concentradas. No entanto, essa fonte ainda possui uma pequena participação na matriz energética do país, sendo mais utilizada como fonte solar térmica para o aquecimento de água (Pereira et al., 2006).

Ainda segundo Pereira et al. (2006), o aproveitamento do potencial econômico dessa fonte depende do desenvolvimento de tecnologias competitivas, para a conversão e o armazenamento da mesma, além do cunho científico sobre o aproveitamento da fonte.

\subsubsection{A energia solar no Brasil}

Os dados dos mapas solarimétricos utilizados nessa dissertação foram extraídos do Atlas Brasileiros de Energia Solar (Pereira, et al., 2006). Os mapas apresentam os valores médios das estimativas dos totais diários de irradiação solar em uma década de estudos (entre julho de 1995 e dezembro de 2005), com resolução espacial de $10 \mathrm{~km} \times 10 \mathrm{~km}$ (ANEXO A).

No ANEXO A.1, o mapa apresenta a média anual do total diário de irradiação solar global incidente no território brasileiro. Mesmo com as diferenças climáticas nas diversas regiões brasileiras, essa média apresenta boa uniformidade, sendo o maior índice encontrado no norte do estado da Bahia, 6,5 $\mathrm{kWh} / \mathrm{m}^{2}$. A menor irradiação solar global foi a encontrada no litoral norte de Santa Catarina, $4,25 \mathrm{kWh} / \mathrm{m}^{2}$.

O ANEXO A.2 apresenta os mapas de médias sazonais da irradiação global diária para cada uma das estações do ano (Pereira, et al., 2006). 


\subsubsection{A energia solar no Nordeste brasileiro}

O Nordeste brasileiro é o local do país onde o potencial anual médio de energia solar é de $5,9 \mathrm{kWh} / \mathrm{m}^{2}$, que é o maior valor do país. Esse valor, no plano inclinado, é de $5,8 \mathrm{kWh} / \mathrm{m}^{2}$ (Pereira, et al., 2006). Assim, é a região com maior disponibilidade energética de fonte solar.

De acordo com Pereira et al. (2006), o Nordeste é a região que apresenta a menor variabilidade interanual das médias anuais do total diário de irradiação solar global na superfície. Esse valor ficou entre 5,7 e $6,1 \mathrm{kWh} / \mathrm{m}^{2}$.

\subsubsection{Viabilidade econômica da energia solar fotovoltaica considerando seus custos ambientais}

A metodologia adotada para o cálculo dos custos da energia fotovoltaica considerou a vida útil do sistema, gerando energia elétrica por 30 anos, devido à vida útil dos painéis fotovoltaicos. O período de vida útil dos componentes dos sistemas foi considerado 5 anos para banco de baterias e 10 anos para controladores de carregamento e inversores de frequência. Dessa forma, o custo de um sistema fotovoltaico leva em consideração o valor inicial dos equipamentos e suas substituições ao final da vida útil que são: 1 vez, o custo dos painéis solares, 6 vezes, o custo do banco de baterias, 3 vezes, o custo dos controladores de carga e 3 vezes, o custo dos inversores de frequência, além dos componentes de suporte considerados no trabalho (Shayani et al., 2006).

As adequações nos cálculos e nas especificações do sistema solar fotovoltaico foram feitas mediante esclarecimentos obtidos junto ao pesquisador do grupo de Sistemas Fotovoltaicos do Instituto de Eletrotécnica e Energia da Universidade de São Paulo (IEE/USP), Dr. Roberto Zilles².

O Dr. Roberto Zilles é professor do Instituto de Eletrotécnica e Energia da Universidade de São Paulo, membro do Editorial Board da Revista Progress in Photovoltaics: Research and Applications e chefe da Divisão Científica de Energia e Ambiente do IEE/USP. Além disso, possui diversos projetos de pesquisa desenvolvidos relacionados à sistemas fotovoltaicos.

Para esse trabalho, serão considerados sistemas fotovoltaicos em minirredes e em sistemas isolados.

\footnotetext{
${ }^{2}$ Entrevista feita com o Dr. Roberto Zilles em outubro de 2012 nas dependências do IEE/USP.
} 
Neste estudo, a energia que será gerada utilizando-se minirredes abastecerá quatro residências com $50 \mathrm{kWh} / \mathrm{mês}$ cada, totalizando $200 \mathrm{kWh} / \mathrm{mês}$. No caso dos sistemas isolados, cada sistema abastecerá apenas uma residência com $80 \mathrm{kWh} / \mathrm{mês}$, pois foram obtidos o orçamento dos componentes por meio da Kyocera Solar para esta configuração.

Para o dimensionamento do sistema fotovoltaico, considera-se a energia disponível em um determinado período no local onde será implementado. A irradiação solar é dada em $\mathrm{kWh} / \mathrm{m}^{2}$ que é convertida em Horas de Sol Pleno (HSP) para os cálculos. O HSP, segundo Barreto (2008), é dado pelo número de horas de sol em média diária com uma intensidade de $1.000 \mathrm{~W} / \mathrm{m}^{2}$, sendo equivalente ao valor total diário incidente na superfície do gerador em $\mathrm{kWh} / \mathrm{m}^{2}$. Então, considerando que a irradiação solar máxima na superfície terrestre seja de $1.000 \mathrm{~W} / \mathrm{m}^{2}$, um HSP é a energia recebida com essa irradiância durante uma hora. O valor de HSP em um dia é calculado dividindo-se a energia recebida em $\mathrm{kWh} / \mathrm{m}^{2}$ pelo nível de irradiância de pico, $1.000 \mathrm{~W} / \mathrm{m}^{2}$ (Barreto, 2008).

De acordo com a região demográfica, o valor médio diário anual de HSP varia entre 4 e 6 (Barreto, 2008). Para esse estudo, será considerado o valor de HSP médio da região nordeste do Brasil. De acordo com o Atlas Brasileiro de Energia Solar (Pereira et al., 2006) o potencial anual médio de energia solar para - Nordeste brasileiro, que é a região do país que apresenta a maior disponibilidade desta fonte, é de 5,9 kWh/m², ou seja, 5,9 HSP (ANEXO A.1).

De acordo com Zilles, não é necessário considerar a área das placas dos painéis fotovoltaicos para os cálculos, e, também, o Fator de Capacidade, que é o mais difícil de ser obtido por necessitar de fatores de geração e também de consumo específicos. Para os cálculos foram adotados o Fator de Segurança do sistema de 1,25, o desempenho total do sistema (PR) de 0,75, que leva em conta todas as perdas do sistema (baterias, inversores e aproveitamento solar), o HSP da região e a Potência nominal $\left(P_{N}\right)$ do sistema fotovoltaico. A seguir, os cálculos para as minirredes e para sistemas isolados serão demonstrados.

\subsubsection{Equações e cálculos para as minirredes}

A geração de energia para um dia por meio de um sistema fotovoltaico é dada pela equação (5.1): 


$$
E_{F V 1 d i a}=P_{N} \cdot H S P \cdot P R
$$

Onde:

$E_{F V 1 d i a}=$ energia do sistema solar fotovoltaico para 1 dia $(\mathrm{kWh})$;

$P_{N}=$ potência nominal $(\mathrm{W}$ ou $\mathrm{kW})$;

$H S P=$ número de horas de sol pleno $(\mathrm{h})$;

$P R=$ desempenho total do sistema.

As minirredes com potência de pico de $2160 \mathrm{Wp}(\mathrm{PN}=2,16 \mathrm{kWp})$ fornecem $200 \mathrm{kWh} /$ mês para quatro famílias de cinco pessoas cada (50 kWh/mês por família).

Para o caso das minirredes, o valor da $E_{F V 1 d i a(m r)}$, obtido pela equação (5.1) é de:

$$
E_{F V 1 \operatorname{dia}(m r)}=9,558 \mathrm{kWh}
$$

Considerando que o tempo de vida útil desse sistema é de 30 anos,

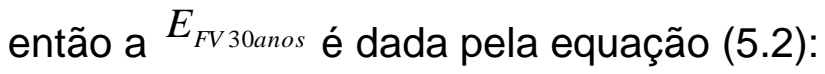

$$
E_{F V 30 a n o s}=E_{F V 1 d i a} \cdot n_{d} \cdot n_{a}
$$

Onde:

$E_{F V 30 a n o s}=$ energia fotovoltaica em 30 anos $(\mathrm{kWh})$;

$n_{d}=$ número de dias em um ano;

$n_{a}=$ número de anos.

Assim, para o sistema em minirredes esse valor é de:

$$
E_{F V 30 \text { anos }(m r)}=104.660,1 \mathrm{kWh}
$$


O custo de um sistema fotovoltaico em minirredes é dado pela equação (5.3), considerando todos os componentes e substituições necessárias por toda a vida útil do empreendimento, conforme sugere a literatura (Shayani et al., 2006).

$$
V_{T S S(m r)}=1 \cdot V_{M F}+6 \cdot V_{B}+3 \cdot V_{C}+3 \cdot V_{I}+1 \cdot V_{E F}+1 \cdot V_{A B}+1 \cdot V_{K I}+1 \cdot V_{S I}(5.3)
$$

Onde:

$$
\begin{aligned}
& V_{T S S(m r)}=\text { valor total dos componentes do sistema solar em minirrede } \\
& V_{M F}=\text { valor do conjunto de módulos fotovoltaicos; } \\
& V_{B}=\text { valor do banco de baterias; } \\
& V_{C}=\text { valor do controlador de carga; } \\
& V_{I}=\text { valor do inversor de potência; } \\
& V_{E F}=\text { valor da estrutura de fixação; } \\
& V_{A B}=\text { valor do armário para baterias; } \\
& V_{K I}=\text { valor do kit de instalação; } \\
& V_{S I}=\text { valor médio do serviço de instalação do sistema. }
\end{aligned}
$$

A equação (5.4) mostra o número de sistemas necessários para o atendimento à população pelas de minirredes:

$$
n_{S S(m r)}=\frac{\frac{n^{\mathrm{o}} h a b}{5}}{4}
$$

Onde:

$n_{S S(m r)}=$ número de sistemas solares em minirrede necessários;

no hab = número de habitantes projetados para o município.

A partir desses dados é possível obter calcular a energia total gerada pelos sistemas em 30 anos por meio da equação (5.5). 
$E_{F V 30 a n o s T}=E_{F V 30 a n o s} \cdot n_{s s}$

Onde:

$E_{F V 30 a n o s T}=$ energia total gerada pelos sistemas fotovoltaicos em 30 anos;

$n_{S S}=$ número de sistemas solares.

Os valores de cada um dos componentes para um sistema fotovoltaico serão apresentados na TAB 5.1. As cotações foram feitas no mês de dezembro de 2012, junto a Kyocera Solar (2012).

TABELA 5.1 - Valores dos componentes de um sistema solar fotovoltaico (minirrede) de $200 \mathrm{kWh} /$ mês (MIGDI) para o Nordeste brasileiro

\begin{tabular}{c|c|c|c}
\hline Discriminação & Quantidade & $\begin{array}{c}\text { Preço unitário com } \\
\text { impostos (R\$) }\end{array}$ & $\begin{array}{c}\text { Preço total com } \\
\text { impostos (R\$) }\end{array}$ \\
\hline $\begin{array}{c}\text { Módulo fotovoltaico } \\
\text { KD240 (240Wp) }\end{array}$ & 9 & $1.222,22$ & $10.999,98$ \\
\hline $\begin{array}{c}\text { Estrutura de fixação } \\
\text { para 9 módulos }\end{array}$ & 1 & $1.500,00$ & $1.500,00$ \\
\hline $\begin{array}{c}\text { Controlador de } \\
\text { carga MPPT 60/150 }\end{array}$ & 1 & $7.000,00$ & $7.000,00$ \\
\hline $\begin{array}{c}\text { Bateria Estacionária } \\
\text { 150Ah }\end{array}$ & 9 & $1.000,00$ & $9.000,00$ \\
\hline $\begin{array}{c}\text { Inversor/Carregador } \\
\text { 6048 }\end{array}$ & 1 & $15.000,00$ & $15.000,00$ \\
\hline $\begin{array}{c}\text { Armário para } \\
\text { baterias }\end{array}$ & 1 & $3.000,00$ & $3.000,00$ \\
\hline Kit de instalação & 1 & $9.300,00$ & $9.300,00$ \\
\hline $\begin{array}{c}\text { Serviço de } \\
\text { instalação }\end{array}$ & 1 & $14.000,00$ & $14.000,00$ \\
\hline $\begin{array}{c}\text { Preço total de 1 } \\
\text { sistema com } \\
\text { impostos (R\$) }\end{array}$ & & & $69.799,98$ \\
\hline
\end{tabular}

Fonte: Kyocera Solar do Brasil (2012).

O valor do custo ambiental a ser inserido nos cálculos de viabilidade serão avaliados a partir do custo evitado, que é a diferença entre o custo ambiental do diesel (VERA) e o custo ambiental da fonte em questão.

O VERA do diesel e o VERA da energia solar fotovoltaica podem ser calculados pela equação (5.6):

$$
V E R A=E_{30 \text { anos }} \cdot V_{C E R} \cdot E m C_{e q}
$$


Onde:

$V E R A=$ valor econômico do recurso ambiental ar poluído pela fonte analisada;

$E_{30 a n o s}=$ energia em 30 anos;

$V_{C E R}=$ valor do crédito de carbono;

$E m C_{e q}=$ emissões de carbono equivalente (toneladas).

O valor adotado para cada crédito de carbono foi de US\$5,00. A cotação utilizada para o dólar foi de 1 US $\$=R \$ 2,2779$. As emissões de carbono equivalente utilizadas são as constantes da TAB. 4.1: $755 \mathrm{gCO}_{2} \mathrm{eq} / \mathrm{kWh}_{\mathrm{EI}}$ $\left(0,000755 \mathrm{tCO}_{2} \mathrm{eq} / \mathrm{kwh}_{\mathrm{EI}}\right)$ para o diesel e 0 para a energia solar fotovoltaica.

Então, o custo evitado para o meio ambiente, utilizando a energia solar fotovoltaica, é dado pela equação (5.7):

$$
C E_{F V}=V E R A_{\text {solar }}-V E R A_{\text {diesel }}
$$

Onde:

$C E_{F V}=$ custo evitado pela utilização da energia solar fotovoltaica;

Assim, o custo total do empreendimento de energia solar fotovoltaica em 30 anos é dado pela equação (5.8). Nessa equação é inserido o valor obtido da externalidade da fonte de energia em questão para análise da viabilidade econômica.

$$
C T E_{F V}=n_{S S} \cdot V_{T S S}+C E_{F V}
$$

Onde:

$$
\begin{aligned}
C T E_{F V}= & \text { custo total do empreendimento da energia solar fotovoltaico } \\
& (\text { em } \mathrm{R} \$) .
\end{aligned}
$$

Então, o valor do kWh gerado em 30 anos para um sistema fotovoltaico é obtido pela equação (5.9): 


$$
V_{k W h(F V)}=\frac{C T E_{F V}}{E_{F V \text { 30anos } T}}
$$

Onde:

$V_{k W h(F V)}=$ valor da energia por $\mathrm{kWh}(\mathrm{R} \$ / \mathrm{kWh})$.

A seguir, as equações e cálculos para sistemas isolados serão apresentados.

\subsubsection{Equações e cálculos para sistemas isolados}

Para sistemas isolados com potência de pico total de $1120 \mathrm{Wp}$ $(1,12 \mathrm{kWp})$ que fornecem energia para uma família de cinco pessoas com potência de $80 \mathrm{kWh} /$ mês, o valor da $E_{F V 1 d i a(s i)}$, obtido pela equação (5.1), é de:

$$
E_{F V 1 d i a(s i)}=4,956 \mathrm{kWh}
$$

Considerando o tempo de vida útil do sistema de 30 anos, então a $E_{F V \text { 30anos(si) }}$ é dada pela equação (5.2):

$$
E_{F V 30 a n o s(s i)}=54.268,2 \mathrm{kWh}
$$

O custo do sistema fotovoltaico em sistemas isolados é dado pela equação (5.10) considerando o número de componentes necessários por toda a vida útil do empreendimento, conforme a literatura sugere.

$$
V_{T S S(s i)}=1 \cdot V_{M F}+6 \cdot V_{B}+3 \cdot V_{C}+3 \cdot V_{I}+1 \cdot V_{E F}+1 \cdot V_{Q}+1 \cdot V_{M E}+1 \cdot V_{S I}(5.10)
$$

Onde:

$V_{T S S(s i)}=$ valor total do sistema solar isolado em 30 anos;

$V_{M F}=$ valor do conjunto de módulos fotovoltaicos;

$V_{B}=$ valor do banco de baterias; 


$$
\begin{aligned}
& V_{C}=\text { valor do controlador de carga; } \\
& V_{I}=\text { valor do inversor de potência; } \\
& V_{E F}=\text { valor da estrutura de fixação; } \\
& V_{Q}=\text { valor do quadro pré-moldado; } \\
& V_{M E}=\text { valor do material elétrico para instalação; } \\
& V_{S I}=\text { valor médio do serviço de instalação do sistema. }
\end{aligned}
$$

A equação (5.11) demonstra o número de sistemas necessários para o atendimento à população por meio de sistemas isolados:

$$
n_{S S(s i)}=\frac{n^{\mathrm{o}} h a b}{5}
$$

Onde:

$n_{S S(s i)}=$ número de sistemas solares isolados necessários;

$n^{\circ} h a b=$ número de habitantes projetados para o município.

Os dados para os cálculos de um sistema isolado são apresentados na TAB. 5.2. As cotações foram feitas no mês de dezembro de 2012 junto a Kyocera Solar (2012). 
TABELA 5.2 - Valores dos componentes de um sistema solar fotovoltaico de 80kWh/mês (SIGFI80) para o Nordeste brasileiro (sistema isolado)

\begin{tabular}{c|c|c|c}
\hline Discriminação & Quantidade & $\begin{array}{r}\text { Preço unitário } \\
\text { com impostos (R\$) }\end{array}$ & $\begin{array}{c}\text { Preço total com } \\
\text { impostos (R\$) }\end{array}$ \\
\hline $\begin{array}{c}\text { Módulo fotovoltaico } \\
\text { KD140 (140Wp) }\end{array}$ & 8 & 900,00 & $7.200,00$ \\
\hline $\begin{array}{c}\text { Estrutura de fixação } \\
\text { para 4 módulos }\end{array}$ & 2 & $2.651,61$ & $5.303,22$ \\
\hline $\begin{array}{c}\text { Controlador de } \\
\text { carga Tristar 45 } \\
\text { 12V/45a }\end{array}$ & 2 & 530,48 & $1.060,96$ \\
\hline $\begin{array}{c}\text { Bateria DF2500 } \\
\text { 165Ah/100h, 12Vcc }\end{array}$ & 8 & 757,00 & $6.056,00$ \\
\hline $\begin{array}{c}\text { Inversor 1500W } \\
\text { 12Vcc/110 ou } \\
\text { 220Vca }\end{array}$ & 1 & $3.237,63$ & $3.237,63$ \\
\hline $\begin{array}{c}\text { Quadro S80 pré- } \\
\text { moldado }\end{array}$ & 1 & $1.020,43$ & $1.020,43$ \\
\hline $\begin{array}{c}\text { SIGFI80 material } \\
\text { elétrico }\end{array}$ & 1 & $1.632,26$ & $1.632,26$ \\
\hline $\begin{array}{c}\text { Serviço de } \\
\text { instalação S80 }\end{array}$ & 1 & $7.986,32$ & $7.986,32$ \\
\hline $\begin{array}{c}\text { Preço total de 1 } \\
\text { sistema com } \\
\text { impostos (em R\$) }\end{array}$ & & & $33.496,82$ \\
\hline
\end{tabular}

Fonte: Kyocera Solar do Brasil (2012).

O cálculo da energia total gerada em 30 anos pelos sistemas considerados é feito a partir da equação (5.5). Os valores de custo ambiental (o custo evitado) dos sistemas isolados são obtidos a partir da equação (5.7). 0 custo total do empreendimento, considerando o valor da externalidade, é obtido pela equação (5.8). O valor do $\mathrm{kWh}$ gerado em 30 anos para um sistema fotovoltaico é obtido pela equação (5.9). 


\section{METODOLOGIA DE CÁLCULO DE VIABILIDADE ECONÔMICA PARA A BIOMASSA}

Os cálculos de viabilidade econômica da energia da biomassa seguem as normas já descritas anteriormente. Todos os sistemas serão projetados visando atender as normas da ANEEL, já citadas no capítulo anterior. Os custos ambientais serão calculados utilizando o método dos custos evitados pela substituição de geradores diesel pela fonte analisada e internalizados no custo total do empreendimento.

No caso da biomassa, serão dimensionados sistemas em minirredes utilizando dois tipos de matérias primas: a biomassa de resíduos agrícolas e o óleo de dendê, em substituição ao óleo diesel.

Uma breve descrição geral da biomassa e de suas principais tecnologias será apresentada e, também, serão demonstradas as metodologias de cálculo para as duas opções de biomassa.

\subsection{Biomassa}

Pode ser classificada como biomassa qualquer matéria orgânica passível de ser transformada em energia mecânica, térmica ou elétrica. Ela pode ser considerada como uma forma indireta de energia solar, responsável pela fotossíntese, que é base para os processos biológicos das plantas, produzindo energia química que será convertida em outras formas de energia ou em produtos energéticos. A biomassa pode ser florestal, agrícola e também de rejeitos urbanos e industriais. Seus derivados dependem da matéria-prima utilizada e da tecnologia de processamento para a obtenção dos energéticos. O potencial energético é variável conforme a biomassa (ANEEL, 2008).

A biomassa é considerada uma das grandes alternativas para a diversificação da matriz energética no país e no mundo. É uma das fontes de geração de energia com maior potencial de crescimento para os próximos anos, contribuindo para a redução da utilização dos combustíveis fósseis, já que pode ser utilizada para obtenção de energia elétrica e biocombustíveis. A quantidade estimada de biomassa existente na Terra é de 1,8 trilhões de toneladas (ANEEL, 2008). 
De acordo com dados da ANEEL (2008), a produção de energia elétrica e de biocombustíveis em larga escala está relacionada à biomassa agrícola, tecnologias eficientes e a existência prévia de uma agroindústria forte, com plantações representativas. Além do Brasil possuir uma forte agroindústria, encontra-se também em uma faixa tropical e subtropical, que é melhor região para a produção de biomassa, possuindo todas as condições para tornar-se um grande produtor de derivados dessa fonte.

Para transformar a biomassa nos diversos energéticos, há diversas técnicas, como: combustão direta para obtenção de calor gerando vapor para produção de eletricidade; a pirólise ou carbonização, que converte um combustível sólido em outro de melhor qualidade; a gaseificação por meio de reações termoquímicas, que transformam combustíveis sólidos em gás; a digestão anaeróbica, que decompõe matéria orgânica em biogás pela ação de bactérias na ausência de ar; a fermentação, que transforma os açúcares das plantas em álcool e gera resíduos aproveitáveis em termelétricas e a transesterificação, que é a reação de óleos vegetais que podem gerar o biodiesel (ANEEL, 2008).

Todas as tecnologias para a obtenção de eletricidade a partir da biomassa preveem a conversão da matéria-prima em um produto intermediário, que será utilizado para gerar energia mecânica, que acionará o gerador de energia elétrica (ANEEL, 2008).

A utilização da energia da biomassa possui dois fatores de extrema relevância: seu potencial de renovação em curto espaço de tempo e a manutenção do equilíbrio do $\mathrm{CO}_{2}$, já que o gás emitido no processo de queima é capturado durante a fotossíntese (Mourad et al., 2004). Segundo Moret (2004), a utilização da biomassa sustentável na geração de energia elétrica traz um impacto positivo ao meio ambiente mediante à redução de emissões, pois o balanço líquido de $\mathrm{CO}_{2}$ é nulo. Assim, pode-se admitir que a utilização da biomassa na geração de eletricidade gerará uma externalidade positiva.

\subsubsection{A biomassa no Brasil}

A biomassa produzida de partes não aproveitadas, como palha e casca de cultivos de grande volume no Brasil, tem potencial estimado de 167,8 milhões de GJ/ano (Mourad et al., 2004). 
No Brasil, a geração de eletricidade a partir de biomassa tem sido crescente, principalmente, na utilização de sistemas de cogeração, obtendo-se energia térmica e também elétrica. Essa participação pode ser observada na FIG. 6.1.

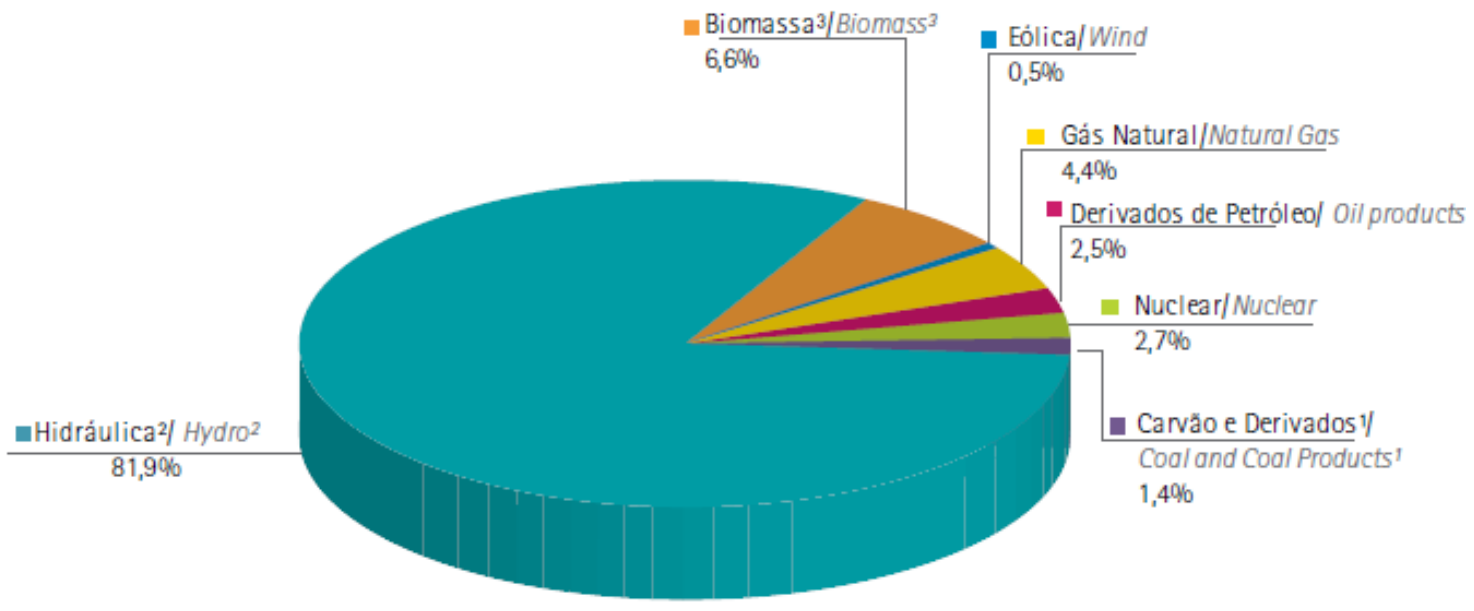

Notas

1 Inclui gás de coqueria

2 Inclui importação de eletricidade

3 Inclui lenha, bagaço de cana, lixívia e outras recuperações

Fonte: EPE, 2012a.

FIGURA 6.1 - Oferta Interna de Energia Elétrica por fonte

De acordo com os dados da ANEEL (2008), em novembro de 2008, existiam 302 termelétricas movidas à biomassa instaladas no país (5,7 mil MW), sendo 13 abastecidas por licor negro ${ }^{3}$ (944 MW); 27 por madeira (232 MW); 3 por biogás (45 MW); 4 por casca de arroz (21 MW) e 252 por bagaço de cana (4 mil MW). Todas eram de pequeno porte com potência instalada de até $60 \mathrm{MW}$, o que favorece a instalação próxima aos centros de consumo.

\subsubsection{A biomassa no Nordeste do Brasil}

Nas TAB. 6.1 a 6.8 é possível visualizar um panorama da disponibilidade energética existente de biomassa no Nordeste brasileiro. As tabelas foram elaboradas a partir de dados obtidos junto à CENBIO (2012).

\footnotetext{
${ }^{3} \mathrm{O}$ licor negro é um subproduto do processo de cozimento Kraft utilizado na produção de polpa celulósica, utilizada para fabricação de papel (Melo et al., 2011).
} 
TABELA 6.1 - Potencial de produção de biogás a partir de suínos no Nordeste brasileiro*

\begin{tabular}{c|c|c|c}
\hline $\boldsymbol{n}^{\text {o de cabeças }}$ & $\boldsymbol{m}^{3} \mathrm{CH}_{4} /$ hora & potencial (MW) & energia (MWh/dia) \\
\hline 6.290 .004 & $16.167,12$ & 37 & 849 \\
\hline
\end{tabular}

* $\mathrm{Kg}$ de esterco/dia unidade geradora $=2,25$, concentração de metano $=0,66$ e volume específico do metano $=0,67 \mathrm{~kg} \mathrm{CH} / \mathrm{m}^{3} \mathrm{CH}_{4}$

Fonte: CENBIO, 2002.

TABELA 6.2 - Potencial da geração de energia a partir de resíduos de cana-deaçúcar no Nordeste brasileiro em um cenário de $30 \mathrm{kWh} / \mathrm{t}$ cana*

\begin{tabular}{c|c|c}
\hline tonelada de cana moída & energia MWh/ano & potencial MW/safra \\
\hline 70.057 .439 & $2.101 .723,17$ & 377,80 \\
\hline
\end{tabular}

* Safra de 5563 horas/ano.

Fonte: CENBIO, 2002.

TABELA 6.3 - Potencial da geração de energia a partir de resíduos de cana-deaçúcar no Nordeste brasileiro em um cenário de $60 \mathrm{kWh} / \mathrm{t}$ cana*

\begin{tabular}{c|c|c}
\hline tonelada de cana moída & energia MWh/ano & potencial MW/safra \\
\hline 70.057 .439 & $4.303 .446,34$ & 755,61 \\
\hline
\end{tabular}

* Safra de 5563 horas/ano.

Fonte: CENBIO, 2002.

TABELA 6.4 - Potencial da geração de energia a partir de resíduos de cana-deaçúcar na região Nordeste brasileira em um cenário de 120 kWh/t cana* $^{*}$

\begin{tabular}{c|c|c}
\hline tonelada de cana moída & energia MWh/ano & potencial MW/safra \\
\hline 70.057 .439 & 8.406 .893 & 1.010 \\
\hline
\end{tabular}

* Considerando o uso do bagaço, palha e pontas o ano todo, ou seja, 8.322 h/ano.

Fonte: CENBIO, 2002.

TABELA 6.5 - Potencial da geração de energia a partir da biomassa do óleo de dendê no Nordeste brasileiro *

\begin{tabular}{c|c|c|c}
\hline hectares & toneladas de óleo & energia MWh/ano & potencial MW/ano \\
\hline 53.517 & 267.585 & $208.716,30$ & 25,08 \\
\hline
\end{tabular}

* 1 hectare dendê = 5 toneladas de óleo; $\mathrm{PCI}$ do dendê $=9.500 \mathrm{kcal} / \mathrm{kg}$.

Fonte: CENBIO, 2002. 
TABELA 6.6 - Potencial da geração de energia a partir da biomassa de resíduos agrícolas no Nordeste brasileiro

\begin{tabular}{c|c|c|c|c}
\hline $\begin{array}{c}\text { amendoim } \\
\text { energia } \\
\text { MWh/ano }\end{array}$ & $\begin{array}{c}\text { arroz } \\
\text { energia } \\
\text { MWh/ano }\end{array}$ & $\begin{array}{c}\text { coco } \\
\text { energia } \\
\text { MWh/ano }\end{array}$ & $\begin{array}{c}\text { total } \\
\text { MWh/ano }\end{array}$ & $\begin{array}{c}\text { potencial } \\
\text { MWh/ano }\end{array}$ \\
\hline $2.609,05$ & $192.484,91$ & $318.877,31$ & $513.971,27$ & 61,76 \\
\hline
\end{tabular}

* Os resíduos considerados são as cascas; soma do total de resíduos agrícolas em caldeiras com $\mathrm{y}=15 \%$.

Fonte: CENBIO, 2002.

TABELA 6.7- Potencial da geração de energia a partir de resíduos da silvicultura no Nordeste brasileiro * com eficiência de $15 \%$ **

\begin{tabular}{c|c|c|c}
\hline $\begin{array}{c}\text { madeira em tora } \\
\left(\mathbf{m}^{\mathbf{3}}\right)^{* * *}\end{array}$ & $\begin{array}{c}\text { conversão } \mathbf{m 3} \text { para } \\
\mathbf{k g}\end{array}$ & $\begin{array}{c}\text { energia MWh/ano } \\
\boldsymbol{\eta}=\mathbf{1 5 \%}\end{array}$ & $\begin{array}{c}\text { potencial } \mathbf{M W h} / \mathbf{a n o} \\
\boldsymbol{\eta}=\mathbf{1 5 \%}\end{array}$ \\
\hline 16.683 .908 & $11.345 .057,44$ & $1.978 .789,09$ & 237,78 \\
\hline
\end{tabular}

* $15 \%$ dos resíduos deixados no campo não são considerados. Resíduos do preparo da madeira $=50 \%$. PCI resíduo $=$ $2000 \mathrm{kcal} / \mathrm{kg}$.

${ }^{\star *} \eta=15 \%$ ciclos a vapor de pequeno porte (de $200 \mathrm{~kW}$ a $\left.10 \mathrm{MW}\right)$.

*** $1 \mathrm{~m} 3$ de madeira para energia = 0,680 ton. (Florestar Estatístico, 2004 apud CENBIO, 2012).

Fonte: CENBIO, 2002.

TABELA 6.8 - Potencial da geração de energia a partir de resíduos da silvicultura no Nordeste brasileiro com eficiência de $30 \%^{*}$

\begin{tabular}{c|c|c|c}
\hline $\begin{array}{c}\text { madeira em tora } \\
\left(\boldsymbol{m}^{\mathbf{3}}\right)\end{array}$ & $\begin{array}{c}\text { conversão } \mathbf{m 3} \text { para } \\
\boldsymbol{k g}\end{array}$ & $\begin{array}{c}\text { energia } \mathbf{M W h} / \text { ano } \\
\boldsymbol{\eta}=\mathbf{3 0} \%\end{array}$ & $\begin{array}{c}\text { potencial } \mathbf{M W h} \text { /ano } \\
\boldsymbol{\eta}=\mathbf{3 0} \%\end{array}$ \\
\hline 16.683 .908 & $11.345 .057,44$ & $3.957 .578,18$ & 475,56 \\
\hline
\end{tabular}

${ }^{*} \eta=30 \%$ ciclos a vapor de grande porte (acima de $10 \mathrm{MW}$ ).

Fonte: CENBIO, 2002

No ANEXO B, os mapas referentes aos dados de resíduos agrícolas e óleo de dendê podem ser visualizados. Todos os mapas podem ser encontrados no Atlas de Bioenergia do Brasil (Coelho et al., 2012).

\subsubsection{Viabilidade econômica da biomassa considerando seus custos ambientais}

Este tópico apresenta o estudo de viabilidade econômica da biomassa para a região nordeste do Brasil.

Mourad et al. (2004) afirmam que a biomassa é uma das fontes mais adequadas para a geração de energia proveniente do calor entres as fontes 
renováveis, o que a torna uma boa substituta para o óleo combustível (no caso desse trabalho, do óleo diesel). A biomassa sustentável, como os resíduos agrícolas, contribui para o aumento da oferta de energia elétrica e também para o desenvolvimento sustentável. A utilização de recursos energéticos regionais traz vantagens locais, econômicas e sociais (Moret, 2004).

Para a escolha e dimensionamento dos sistemas a base de biomassa desse trabalho, foi feita, além das pesquisas na literatura, uma entrevista com a Prof. Dra. Suani Teixeira Coelho ${ }^{4}$, pesquisadora coordenadora do Centro Nacional de Referência em Biomassa além de professora e orientadora do Programa de Pós-Graduação em Energia (PPGE) da USP. Além disso, possui diversas pesquisas e projetos desenvolvidos na área de bionergia.

Após entrevista com a Prof. Dra. Suani Teixeira Coelho, optou-se neste trabalho, por estudar a utilização de resíduos agrícolas para a aplicação em um cálculo que pudesse atender à todo o Nordeste. Nessa região, a biomassa de resíduos agrícolas pode ser encontrada em boa parte dos municípios, o que não acontece com as outras biomassas analisadas. Os resíduos agrícolas estão disponíveis de forma mais distribuída pela região e possuem um alto potencial para a geração elétrica. De acordo com os dados da CENBIO (2012), o potencial de geração dos resíduos agrícolas na região Nordeste do país é de 61,76 MW ou 1.027.942,54 MWh/ano.

O potencial dessa fonte pode ser comprovado por estudos, como o de Moret (2004), que analisou a substituição do diesel pelos resíduos agrícolas. O autor comprova que é possível substituir com tranquilidade a utilização do óleo por resíduos agrícolas em todos os municípios do estado de Rondônia que utilizam esse combustível para gerar energia elétrica.

Os resíduos agrícolas são aqueles compostos fundamentalmente de celulose. Sua preparação para obtenção de energia é relativamente fácil, já que são facilmente pré-processados (Moret, 2004).

A utilização da biomassa residual para a geração de energia causa menor impacto no equilíbrio de mercado, pois não afeta o oferta e demanda de outros usos da biomassa já que considera os resíduos do processo produtivo (Mourad et al., 2004).

\footnotetext{
${ }^{4}$ A Prof. Dra. Suani Teixeira Coelho foi entrevistada nas dependências do CENBIO em 15 de janeiro de 2013.
} 
A Prof. Dra. Suani Teixeira Coelho sugeriu, para a geração de energia elétrica a partir dos resíduos agrícolas, a utilização da técnica de geração de vapor com pequenas caldeiras, utilizando geradores de $200 \mathrm{~kW}$, por já ser um processo maduro e com produção nacional. No entanto, para atender à legislação já citada, serão utilizados geradores de $100 \mathrm{~kW}$. Segundo a pesquisadora, seria possível solicitar esse tipo de geradores aos fabricantes. Esse sistema possui um rendimento de $20 \%$ em média. O ciclo a vapor com turbinas de contrapressão, de acordo com a ANEEL (2008), é empregado de forma integrada a processos produtivos. Isso é feito por meio da cogeração: a biomassa é queimada diretamente em caldeiras, e a energia térmica gerada é utilizada na produção do vapor, que aciona as turbinas usadas para geração de energia elétrica. $O$ vapor que seria liberado no final dos processos pode ser utilizado para o atendimento das necessidades térmicas do processo.

O uso de sistemas de gaseificação, outra opção para utilização da biomassa, segundo Prof. Dra. Suani Teixeira Coelho, ainda é restrito para a geração de energia devido aos seus altos custos de implementação e ausência de tecnologias nacionais viáveis, não competitivas comercialmente para a biomassa.

Mourad et al. (2004) confirmam que algumas técnicas podem ser utilizadas para a conversão da biomassa em energia, no entanto, a técnica mais utilizada é o uso da biomassa como combustível sólido por meio da queima direta. Nesse sistema, a biomassa é diretamente queimada em caldeiras, e a energia térmica produzida é utilizada na geração de vapor, que acionará uma turbina para a geração de energia elétrica. Então, a biomassa é colocada diretamente na caldeira e queimada. Os gases gerados passam por um processo de limpeza e são liberados enquanto o vapor aciona a turbina que move o gerador elétrico. Esses sistemas possuem eficiência térmica variando entre 14 e 25\%, e seus custos de capital são baixos. (Pinto, 2008). Os potenciais anteriormente apresentados para a biomassa, calculados pela CENBIO (2012), consideram uma eficiência de $15 \%$. Pinto (2008) adota uma eficiência de conversão de $25 \%$ para seus cálculos.

Os resíduos de várias culturas podem ser utilizados para a conversão em energia elétrica, por meio de pequenos sistemas de até $600 \mathrm{~kW}$ em áreas onde há disponibilidade de resíduos, como áreas rurais. Utilizando grupos 
geradores, técnica que será adotada nesse estudo, é possível gerar, em média, para cada $3 \mathrm{~kg}$ de resíduos, $1 \mathrm{kWh}$ de eletricidade (Mourad et al., 2004). Nesse caso o poder calorífico seria de 0,33 kWh/kg. Blasques et al. (2005) propõem que pode ser gerado $1 \mathrm{kWh}$ com 1,2 a 1,4 kg de biomassa, o que leva a um poder calorífico médio da biomassa de $0,77 \mathrm{kWh} / \mathrm{kg}$. Portanto, será adotado, então, um valor médio entre os encontrados na literatura: 0,55 kWh/ kg. Essa informação é importante para o cálculo de consumo de combustível do sistema.

É importante, quando se usa resíduos agrícolas para gerar energia, conhecer as características da biomassa, como o seu poder calorífico e a quantidade de resíduo que será produzido na região (Pinto, 2008).

A proposta para esse estudo é a utilização da biomassa disponível localmente e a geração descentralizada, presumindo que o transporte da biomassa utilizada será por curtas distâncias. Por esse motivo, os valores de transporte não serão considerados nos cálculos.

Contudo, devido às vantagens que serão apresentadas para o uso do óleo de dendê e também para adequar o já proposto por Vanni em 2008 na primeira versão do programa PEASEB, essa fonte também será analisada e disponibilizada para o usuário. É importante salientar que, de acordo com dados do Atlas de Bionergia do Brasil (CENBIO, 2012) esse insumo é gerado predominantemente em alguns municípios da Bahia e também da Paraíba, como pode ser observado no ANEXO B.2.

A opção pela adoção pelo estudo dos resíduos agrícolas se deu pela necessidade de uma fonte que atendesse amplamente a região Nordeste, já que o dendê, apesar de possuir diversas vantagens, somente é produzido em poucas localidades dessa região, e necessita, também, da implantação de uma planta industrial para a sua produção.

A seguir são apresentados os cálculos de viabilidade econômica da biomassa de resíduos agrícolas. 


\subsubsection{Cálculo da Viabilidade Econômica para Biomassa de Resíduos Agrícolas}

Segundo Blasques et al. (2005), em sistemas isolados em que a única fonte é a biomassa, a geração de energia pode ser expressa por (6.1) com $k_{P}=1,10$ :

$$
E_{\text {Bio }}=k_{P} \cdot P_{L} \cdot \Delta T \cdot L
$$

Onde:

$E_{B i o}=$ energia elétrica gerada pelo sistema de biomassa (kWh);

$k_{P}=$ fator de perdas na rede $(1,10)$;

$P_{L}=$ potência instalada $(\mathrm{kW})$;

$\Delta T=$ tempo em horas;

$L=$ fator de carga $(0,275)$.

O fator de carga $L$ é a razão entre a energia elétrica consumida e a que seria consumida caso a carga operasse com sua potência instalada durante um intervalo de tempo. Os fatores de carga típicos para esse tipo de sistema estão em torno de 25 a 30\% (Blasques et al., 2005). Para os cálculos, será adotado um fator de carga médio entre os típicos: 27,5\%.

Para determinar os custos dos sistemas para a população das comunidades selecionadas, todos os cálculos serão feitos para o tempo de vida do sistema, que é de 25 anos. Como mencionado, o MIGDI é um microssistema isolado de geração e distribuição de energia elétrica com potência instalada total de geração de até $100 \mathrm{~kW}$.

As minirredes de biomassa deverão fornecer energia como dimensionado para os sistemas solares, $50 \mathrm{kWh} /$ mês para cada residência.

Então a energia gerada por este sistema, equação (6.1), em 1 mês e em 25 anos, são respectivamente:

$$
E_{\text {BioM }}=21.780 \mathrm{kWh} \text { (em } 1 \text { mês) }
$$




$$
E_{\text {Bio25anos }}=6.624 .750 \mathrm{kWh}(\mathrm{em} 25 \text { anos })
$$

Onde:

$$
\begin{gathered}
E_{B i o M}=\text { energia elétrica gerada pelo sistema de biomassa em um mês } \\
\text { considerando-se } 30 \text { dias ( } \mathrm{kWh} / \mathrm{mês}) ; \\
E_{\text {Bio25anos }}=\text { energia elétrica gerada pelo sistema de biomassa em } 25 \\
\text { anos ( } \mathrm{kWh} / 25 \text { anos). }
\end{gathered}
$$

A partir do montante mensal produzido por um sistema será determinado o número de sistemas necessários para o atendimento de cada comunidade. Cada sistema atenderá a um determinado número de famílias constituídas de 5 componentes, em média, com $50 \mathrm{kWh} / \mathrm{mês}$ cada uma. Dessa forma, este valor será obtido por (6.2).

$$
n_{S B}=\frac{\frac{n h}{5}}{\frac{E_{\text {BioM }}}{E_{\text {Família }}}}
$$

Onde:

$n_{S B}=$ número de sistemas de biomassa necessários;

$n h=$ número de habitantes projetados para o município;

$E_{B i o M}=$ energia elétrica gerada pelo sistema de biomassa (kWh/mês);

$E_{\text {Familia }}=$ energia elétrica fornecida para cada família.

A partir da determinação do número de sistemas a serem implementados é possível obter a quantidade de energia que será efetivamente gerada no município durante toda a vida útil dos sistemas de biomassa, atendendo o número de famílias calculadas a partir da projeção do IBGE. Esse número é calculado pela equação (6.3). Esse dado será necessário para a valoração das externalidades.

$$
E_{E G 25 a n o s}=n_{S B} \cdot E_{\text {Bio25anos }}
$$


Onde:

$E_{E G 25 a n o s}=$ energia efetivamente gerada em 25 anos.

Os custos totais do sistema devem considerar os custos iniciais de implantação $(\mathrm{Cl})$ necessários para o início da operação do sistema de energia, os custos de reposição $(\mathrm{CR})$ dos principais componentes do sistema devido à sua vida útil, os custos de operação (CO) necessários ao funcionamento do sistema, sendo considerados basicamente o custo dos combustíveis e o custo de manutenção (CM) preventiva e corretiva (Blasques et al., 2005).

Para definir o custo de implementação de um sistema de geração de energia que utiliza biomassa como combustível num ciclo térmico utilizando turbinas a vapor, é preciso inicialmente determinar seu ciclo de vida. Os ciclos térmicos de geração de potência a vapor são constituídos por caldeira, turbina, condensador, bomba e equipamentos auxiliares e a durabilidade dos equipamentos está relacionada com diversos fatores, como a qualidade do fluido de trabalho (o vapor) e as devidas manutenções (ANEEL, 2000). Estima-se, de modo geral, que a vida útil dos equipamentos dos ciclos térmicos é de 25 anos (ANEEL, 2000).

Pinto (2008) fornece alguns custos básicos para os custos dos equipamentos por kW instalado para a implementação do sistema utilizando o ciclo térmico (caldeira). O valor fornecido para os equipamentos de conversão é de $\mathrm{R} \$ 3.800,00 / \mathrm{kW}$ instalado e para os acessórios elétricos necessários à operação da central de geração, como chaves, painéis de comando entre outros, é de $\mathrm{R} \$ 570,00 / \mathrm{kW}$ instalado.

Para obter o custo dos equipamentos de geração, multiplica-se o custo do equipamento por $\mathrm{kW}$ instalado pelo potencial de geração em termos de potência instantânea (Pinto, 2008), como mostra a equação (6.4).

$$
C_{E}=C_{E / k W} \cdot P_{L}
$$

Onde:

$C_{E}=$ custo dos equipamentos $(\mathrm{R} \$)$;

$C_{E / k W}=$ custo dos equipamentos por $\mathrm{kW}$ instalado $(\mathrm{R} \$)$. 
Para o cálculo dos custos dos acessórios elétricos, utiliza-se a equação (6.5) (Pinto, 2008).

$$
C_{A E}=P_{L} \cdot C_{A E / k W}
$$

Onde:

$C_{A E}=$ custo dos acessórios elétricos $(\mathrm{R} \$)$;

$C_{A E / k W}=$ custo dos acessórios elétricos por $\mathrm{kW}$ instalado $(\mathrm{R} \$ / \mathrm{kW})$.

Além desses custos, é preciso também considerar os custos para a instalação da casa de máquinas. O cálculo desses custos leva em consideração as faixas de potências geradas. Segundo a TAB. 6.9, para a faixa de potência de até $0,1 \mathrm{MW}$, configuração adotada nesse trabalho, é indicada uma área 50 metros quadrados para a instalação. O custo do $\mathrm{m}^{2}$ da casa de máquinas é de $\mathrm{R} \$ 700,00$ (Pinto, 2008).

TABELA 6.9 - Custo do $\mathrm{m}^{2}$ da casa de máquinas

\begin{tabular}{c|c}
\hline Faixa de Potência & Área Necessária \\
\hline$<0,1 \mathrm{MW}$ & 50 \\
$0,1-1 \mathrm{MW}$ & 100 \\
$1-10 \mathrm{MW}$ & 200 \\
$>10 \mathrm{MW}$ & 250 \\
\hline
\end{tabular}

Fonte: Pinto (2008).

O valor para a casa de máquinas pode ser obtido pela equação (6.6) a seguir.

$$
C_{C M}=\text { Área } \cdot C_{\text {custo/ } m^{2}}
$$

Onde:

$C_{C M}=$ custo da casa de máquinas $(\mathrm{R} \$)$;

Área = área necessária $\left(\mathrm{m}^{2}\right)$; 


$$
\begin{aligned}
C_{\text {custo/m }}^{2}= & \text { custo do } \mathrm{m}^{2} \text { da casa de máquinas para a faixa de potência } \\
& \text { instalada }(\mathrm{R} \$) .
\end{aligned}
$$

Assim, o custo inicial total do sistema (CI) pode ser obtido pelo somatório dos custos dos equipamentos $\left(C_{E}\right)$, dos acessórios elétricos $\left(C_{A E}\right)$ e da casa de máquinas $\left(C_{C M}\right)$, como demonstrado na equação (6.7).

$$
C I=C_{E}+C_{A E}+C_{C M}
$$

Onde:

$C I=$ custo Inicial do sistema $(\mathrm{R} \$)$.

O Custo de Reposição ( $C R$ ) para a biomassa, de acordo com Blasques et al. (2005), pode ser considerado zero e incluso no Custo de Manutenção ( $C M)$, sendo que não haverão substituições dos principais componentes no tempo de vida útil médio do sistema da biomassa.

Ainda segundo Blasques et al. (2005), o $C M$ é calculado sobre a energia gerada pela biomassa (equação 6.1), sendo de $R \$ 0,544 / \mathrm{kWh}$.

O Custo de Operação ( $C O$ ) corresponde aos custos com o combustível (biomassa) que será utilizado na caldeira. O valor por kg de biomassa segundo Blasques et al. (2005) é de $R \$ 0,272 / \mathrm{kg}$. Mesmo tratando-se de resíduos, que não possuem custos para a sua produção, o usuário poderá ter que arcar com custos para a remoção desses resíduos e, por esse motivo, esse valor será considerado nos cálculos. Então, $C O$ pode ser obtido segundo a equação (6.8) dada a seguir:

$$
C O=\frac{k_{P} \cdot P_{L} \cdot \Delta t \cdot L}{p c_{B I O}} \cdot C_{B I O / k g}
$$

Onde:

$C O=$ custo de operação $(\mathrm{R} \$)$;

$k_{P}=$ fator de perda na rede;

$P_{L}=$ potência instalada $(\mathrm{kW})$; 


$$
\begin{aligned}
& L=\text { fator de carga; } \\
& p c_{B I O}=\text { poder calorífico da biomassa }(\mathrm{kWh} / \mathrm{kg}) ; \\
& C_{B I O / \mathrm{kg}}=\text { custo da biomassa por } \mathrm{kg}(\mathrm{R} \$) .
\end{aligned}
$$

Assim, pode-se assumir que o custo total de um sistema de biomassa seja dado pela equação (6.9) considerando a vida útil média do sistema. Admitese que, durante este tempo, não haverá substituições dos principais componentes do sistema, desde que sejam feitas todas as manutenções preventivas e corretivas recomendadas para os componentes.

$$
C T_{B I O}=C I+C R+C O+C M
$$

Onde:

$C T_{B I O}=$ custo total de um sistema de biomassa $(\mathrm{R} \$)$.

Para efetuar os cálculos de viabilidade econômica das biomassas, alguns dos valores de componentes foram atualizados para o caso de sua implementação. Para isso foi utilizada a ferramenta Calculadora do Cidadão, disponibilizada pelo Banco Central do Brasil. Essa ferramenta permite a simulação de aplicações com depósitos regulares e de financiamentos com prestações fixas, o cálculo de valores futuros de um capital e a correção de valores com base em diversos indicadores econômicos (Banco Central do Brasil, 2013a).

Para as correções, será utilizado o IGP-M (Índice Geral de Preços do Mercado). O IGP-M é calculado pela Fundação Getúlio Vargas (FGV) e é uma média ponderada do Índice de Preços por Atacado (60\%), do Índice de Preços ao Consumidor (30\%) e do Índice Nacional de Custo da Construção (10\%) (Banco Central do Brasil, 2013b).

Todos os valores serão atualizados para julho de 2013, a fim de se equipararem ao valor encontrado para o sistema gerador diesel utilizado nos cálculos para o óleo de dendê e ,dessa forma, manter os cálculos equalizados para as duas biomassas permitindo uma comparação justa. Na TAB. 6.10 são disponibilizados os preços que foram descritos para a biomassa de resíduos 
agrícolas, segundo a literatura, e seus respectivos valores atualizados em reais $(R \$)$. Os valores iniciais referem-se às datas de publicação das referências utilizadas nesse trabalho.

Para as correções de valores entre dezembro de 2008 e julho de 2013, o índice de correção no período foi de 1,2631127, com valor percentual correspondente de 26,31127\%. Já para as correções de valores entre outubro de 2005 e julho de 2013, o índice de correção no período foi de 1,5693434, com valor percentual correspondente de 56,93434\%.

TABELA 6.10 - Correção dos valores de custos para resíduos agrícolas

\begin{tabular}{|c|c|c|c|}
\hline Item & $\begin{array}{l}\text { Valor em } \\
\text { out/2005 }\end{array}$ & $\begin{array}{l}\text { Valor em } \\
\text { dez/2008 }\end{array}$ & $\begin{array}{c}\text { Valor atualizado } \\
\text { jul/2013 }\end{array}$ \\
\hline $\begin{array}{c}\text { Custo de equipamentos de } \\
\text { conversão } \\
(\mathrm{R} \$ / \mathrm{kW} \text { instalado) }\end{array}$ & - & $3.800,00$ & $4.799,83$ \\
\hline $\begin{array}{l}\text { Custo de acessórios elétricos } \\
\text { ( } R \$ / k W \text { instalado) }\end{array}$ & - & 570,00 & 719,97 \\
\hline $\begin{array}{l}\text { Custo da casa de máquinas } \\
\left(\mathrm{R} \$ / \mathrm{m}^{2}\right)\end{array}$ & - & 700,00 & 884,18 \\
\hline Custo de Manutenção (R\$/kWh) & 0,544 & - & 0,85 \\
\hline Custo do resíduo $(\mathrm{R} \$ \mathrm{~kg})$ & 0,272 & - & 0,43 \\
\hline
\end{tabular}

Os dados para os cálculos de um sistema baseado em biomassa dos resíduos agrícolas descritos são apresentados na TAB. 6.11.

TABELA 6.11 - Valores dos componentes dos custos de um sistema baseado em resíduos agrícolas

\begin{tabular}{|c|c|}
\hline Item & Valor \\
\hline Custo de equipamentos de conversão ( $R \$$ / kW instalado) & $4.799,83$ \\
\hline Custo de acessórios elétricos ( $\mathrm{R} \$ \mathrm{~kW}$ instalado) & 719,97 \\
\hline Custo da casa de máquinas $\left(R \$ / m^{2}\right)$ & 884,18 \\
\hline Custo de Manutenção ( $R \$ / k W h)$ & 0,85 \\
\hline Custo do resíduo $(\mathrm{R} \$ \mathrm{~kg})$ & 0,43 \\
\hline
\end{tabular}

A partir dos dados referentes à geração e ao custo dos sistemas, é possível obter o valor do custo ambiental do sistema de biomassa. Para a biomassa, esses custos serão avaliados a partir do custo evitado por meio da substituição do óleo diesel pela biomassa, considerando a possibilidade da venda 
de créditos de carbono. Então, o VERA do diesel e o VERA da biomassa podem ser calculados por meio da equação (6.10).

$V E R A=E_{E G 25 a n o s} \cdot V_{C E R} \cdot E m C_{e q}$

Onde:

$V E R A$ = valor econômico do recurso ambiental ar poluído;

$V_{C E R}=$ valor do crédito de carbono;

$E m C_{e q}=$ emissões de carbono equivalente.

O valor adotado para cada crédito de carbono foi de US\$ 5,00 (R\$ 2,2779). As emissões de carbono equivalente utilizadas são as constantes da TAB. 4.1: $755 \mathrm{gCO}_{2} \mathrm{eq} / \mathrm{kWh}_{\mathrm{El}}\left(0,000755 \mathrm{tCO}_{2} \mathrm{eq} / \mathrm{kwh}_{\mathrm{El}}\right)$ para o diesel. Para a biomassa, adota-se emissões zero, já que a literatura admite que o balanço de emissões na utilização dessa fonte é nulo.

O custo evitado para o meio ambiente utilizando a energia da biomassa em substituição ao óleo diesel é obtido pela equação (6.11).

$$
C E_{B I O}=V E R A_{B I O}-V E R A_{D I E S E L}
$$

Onde:

$C E_{B I O}=$ custo evitado pela utilização da energia da biomassa.

Assim, o custo total do empreendimento utilizando biomassa é dado pela equação (6.12). Nessa equação é inserido o valor obtido da externalidade positiva da fonte de energia em questão.

$$
C T E_{B I O}=n_{S B} \cdot C T_{B I O}+C E_{B I O}
$$

Onde:

$C T E_{B I O}=$ custo total do empreendimento utilizando biomassa. 
O valor do kWh gerado em 25 anos para um sistema de biomassa é obtido pela equação (6.13).

$$
V_{k W h(B I O)}=\frac{C T E_{B I O}}{E_{E G 25 a n o s}}
$$

Onde:

$V_{k W h(B I O)}=$ valor do $\mathrm{kWh}$ gerado pelo sistema de biomassa.

Como já citado, a título de adequação ao que foi proposto por Vanni (2008), será feita também a revisão do equacionamento proposto para utilização no PEASEB em situações onde o dendê for viável, já que essa fonte também possui várias vantagens. As equações são dadas no tópico a seguir.

\subsubsection{Cálculo de Viabilidade Econômica da Biomassa de Dendê}

Em 2008, Vanni propôs a utilização de um sistema gerador diesel que utilizaria como combustível o óleo vegetal in natura (óleo de dendê) para a geração de energia elétrica. As revisões feitas nessa dissertação partirão deste pressuposto.

Os óleos vegetais in natura são uma boa alternativa de origem natural para a substituição do óleo diesel em comunidades não eletrificadas, pois existe a possibilidade técnica de serem queimados em geradores diesel entre outras vantagens (Coelho et al. 2005).

Segundo Coelho et al. (2005), algumas mudanças simples no óleo vegetal podem melhorar o seu desempenho como combustível, destacando-se a degomagem e neutralização dos óleos, o fracionamento do óleo de dendê para a utilização da fração menos viscosa e o aumento da pressão da injeção do combustível. O maior desgaste dos motores devido ao uso do óleo de dendê causa um aumento entre 20 a $25 \%$ nos custos de manutenção do sistema, devido à adequação e manutenção preventiva buscando equiparar o tempo de vida do sistema ao mesmo do sistema que utiliza o óleo diesel. Em compensação, o custo de produção do óleo de dendê gira em torno da metade do óleo diesel. 
É importante salientar também que as emissões gasosas geradas pela utilização do dendê estão dentro dos parâmetros encontrados em motores a diesel. Contudo, o óleo de dendê não possui enxofre, e o balanço de emissões da biomassa é zero (Coelho et al., 2005).

Segundo Blasques et al. (2005), em sistemas que utilizam o diesel, a geração pode ser expressa por (6.14) com $k_{P}=1,10$. É adotado o sistema de geração diesel, pois a utilização de óleos vegetais in natura em geradores diesel convencionais já se mostrou possível em diversas experiências, sendo necessário, para isso, apenas algumas adequações tecnológicas específicas (Coelho et al., 2005). Nesse caso, a equação permanece a mesma que foi utilizada para os resíduos agrícolas:

$$
E_{D}=k_{P} \cdot P_{L} \cdot \Delta t \cdot L
$$

Onde:

$E_{D}=$ energia elétrica gerada pelo sistema de dendê (kWh);

$k_{P}=$ fator de perdas na rede $(1,10)$;

$P_{L}=$ potência instalada $(\mathrm{kW})$;

$\Delta t=$ tempo em horas;

$L=$ fator de carga $(0,275)$.

Para determinar os custos dos sistemas, todos os cálculos serão feitos considerando o seu tempo de vida que é de 20 anos (Soares et al., 2000). A partir da equação (6.14), se obtém a energia gerada pelo sistema em 1 mês e em 20 anos. Para o cálculo referente a um mês serão considerados 30 dias.

$$
\begin{aligned}
& E_{D M}=21.780 \mathrm{kWh}(1 \mathrm{mês}) \\
& E_{D 20 a n o s}=5.227 .200 \mathrm{kWh} \text { (20 anos) }
\end{aligned}
$$


Onde:

$E_{D M}=$ energia elétrica gerada pelo sistema de biomassa de dendê em um mês considerando-se 30 dias ( $\mathrm{kWh} / \mathrm{mês})$;

$E_{D 20 a n o s}=$ energia elétrica gerada pelo sistema de biomassa de dendê em 20 anos (kWh/20 anos).

A partir do montante mensal produzido por um sistema será determinado o número de sistemas necessários para o atendimento de cada comunidade. Cada sistema atenderá a um determinado número de famílias constituídas de 5 componentes, em média, com $50 \mathrm{kWh} /$ mês cada uma. Dessa forma, o valor será obtido por (6.15).

$$
n_{S D}=\frac{\frac{n h}{5}}{\frac{E_{D M}}{E_{\text {Familia }}}}
$$

Onde:

$n_{S D}=$ número de sistemas de biomassa necessários

A partir da determinação do número de sistemas a serem implementados, é possível obter a quantidade de energia que será efetivamente gerada no município durante toda a vida útil dos sistemas de biomassa (óleo de dendê), atendendo o número de famílias projetadas. Esse número é calculado por meio da equação (6.16). Esse dado será necessário para a valoração das externalidades.

$$
E_{E G 20 a n o s}=n_{S D} \cdot E_{D 20 a n o s}
$$

Onde:

$E_{E G 20 a n o s}=$ energia efetivamente gerada em 20 anos 
Os custos totais do sistema devem considerar os custos iniciais de implantação $(\mathrm{Cl})$ necessários para o início da operação do sistema de energia, os custos de reposição $(\mathrm{CR})$ dos principais componentes do sistema devido à sua vida útil, os custos de operação (CO) necessários ao funcionamento do sistema, sendo considerados basicamente o custo dos combustíveis e o custo de manutenção (CM) preventiva e corretiva (Blasques et al., 2005).

Para definir o custo de implementação de um sistema de geração de energia que utiliza óleo de dendê como combustível num gerador diesel, é preciso inicialmente determinar seu ciclo de vida. Como já descrito anteriormente, o tempo de vida útil do sistema diesel gerador é de 20 anos.

Para um grupo gerador diesel de $100 \mathrm{~kW}$ de potência (ou $125 \mathrm{kva}$ ), o preço obtido para uma unidade em julho de 2013 é de $\mathrm{R} \$ 57.000,00\left(C_{E}\right)$. O Grupo Gerador de 105/125 kVA é composto por motor Marca CUMMINS TURBO, modelo 6BT5.9-G1, alternador eletrônico, quadro de comando automático e digital, 2 baterias $12 \mathrm{~V}-150 \mathrm{~A} / \mathrm{h}$ com cabos e terminais, um tanque de combustível de 200 litros embutido e um conjunto de coxins vibra-stop (MF Rural, 2013) . $^{5}$

Também é preciso considerar os custos para a instalação da casa de força $\left(C_{C F}\right)$. Segundo Blasques (2005) o custo da casa de força para um sistema a diesel de $15 \mathrm{~kW}$ de potência é de $\mathrm{R} \$ 12.000,00$. Tomando este valor como base, é possível admitir um valor proporcional para o sistema de $100 \mathrm{~kW}$ de potência como sendo de $\mathrm{R} \$ 80.000,00$.

Assim, o custo inicial total do sistema $(C I)$ pode ser obtido pelo somatório dos custos dos equipamentos $\left(C_{E}\right)$ e da casa de força $\left(C_{C F}\right)$, como demonstrado na equação (6.17).

$$
C I=C_{E}+C_{C F}
$$

Onde:

$C I=$ custo Inicial do sistema $(\mathrm{R} \$)$.

O Custo de Reposição $(C R)$ para o grupo gerador diesel que irá operar com óleo de dendê, de acordo com Blasques et al. (2005), pode ser considerado

\footnotetext{
${ }^{5}$ Valor referente à empresa Soto Filho: http://www.sotofilhos.com.br/index.html
} 
zero e incluso no Custo de Manutenção $(C M)$, sendo que não haverá substituições dos principais componentes no tempo de vida útil médio do sistema.

Ainda segundo Blasques et al. (2005), o $C M$ é calculado sobre a energia gerada (equação 6.14), sendo de $R \$ 0,272 / \mathrm{kWh}$ para o óleo diesel. Como mencionado, o custo de manutenção é maior entre 20 a 25\% quando o óleo in natura é utilizado nos geradores diesel. Assim, admitindo um aumento médio de $22,5 \%$, tem-se que o custo de manutenção será de $R \$ 0,333 / \mathrm{kWh}$. O Custo de Operação $(C O)$ é dado pela multiplicação do consumo de combustível pelo valor do óleo utilizado. De acordo com Soares et al. (2000), o consumo de dendê em geradores diesel é de 0,33 litros por kWh gerado. O preço do litro do óleo de dendê pode variar entre $\mathrm{R} \$ 1,80$ e 1,90 (TN Sustentável, 2013). Será adotado o valor médio: $\mathrm{R} \$ 1,85$.

Assim, pode-se assumir que a equação (6.18) calcula o custo total de um sistema de biomassa que utiliza o óleo de dendê.

$$
C T_{D}=C I+C R+C O+C M
$$

Onde:

$C T_{D}=$ custo total de um sistema gerador diesel a óleo de dendê (R $\left.\$\right)$.

Para efetuar os cálculos de viabilidade econômica dos sistemas baseados em óleo de dendê, alguns dos valores de componentes foram atualizados para o caso de sua implementação. Para isso foi utilizada a ferramenta Calculadora do Cidadão, disponibilizada pelo Banco Central do Brasil (Banco Central do Brasil, 2013a).

Para as correções, será utilizado o IGP-M. Para as correções de valores entre outubro de 2005 e julho de 2013, o índice de correção no período foi de 1,5693434 com valor percentual correspondente de 56,93434\%.

Todos os valores serão atualizados para julho de 2013, a fim de se equipararem ao valor encontrado para o sistema gerador diesel utilizado nos cálculos para óleo de dendê e, dessa forma, manter os cálculos equalizados para as duas biomassas utilizadas permitindo uma comparação justa. Na TAB. 6.12 são disponibilizados os preços que foram descritos para a biomassa de óleo de 
dendê, obtidos da literatura, e seus respectivos valores atualizados em reais $(R \$)$. Os valores iniciais referem-se às datas de publicação das referências utilizadas nesse trabalho.

TABELA 6.12 - Correção dos valores de custos para óleo de dendê

\begin{tabular}{c|cc}
\hline Item & Valor em out/2005 & Valor atualizado jul/2013 \\
\hline Custo da casa de força (R\$) & $80.000,00$ & $125.547,47$ \\
\hline $\begin{array}{c}\text { Custo de Manutenção } \\
\text { (R\$/kWh) }\end{array}$ & 0,333 & 0,52 \\
\hline
\end{tabular}

Os dados para os cálculos de um sistema baseado em biomassa de óleo de dendê descritos nesse item encontram-se na TAB. 6.11.

TABELA 6.13 - Valores dos componentes dos custos de um sistema baseado em óleo de dendê

\begin{tabular}{c|c}
\hline Item & Valor \\
\hline Custo do equipamento de conversão (R\$) & $57.000,00$ \\
\hline Custo da casa de força (R\$) & $125.547,47$ \\
\hline Custo de Manutenção $(\mathbf{R} \mathbf{\text { }} \mathbf{k W h})$ & 0,52 \\
\hline Custo do óleo de dendê (R\$/L) & 1,85 \\
\hline
\end{tabular}

A partir dos dados referentes à geração e ao custo dos sistemas, é possível obter o valor do custo ambiental do gerador diesel que utiliza o óleo de dendê. Para o dendê, esses custos serão avaliados a partir do custo evitado por meio da substituição do óleo diesel pelo óleo de dendê, considerando a possibilidade da venda de créditos de carbono. Então, o VERA do diesel e o VERA do óleo de dendê podem ser calculados segundo a equação (6.19).

$$
V E R A=E_{E G 20 a n o s} \cdot V_{C E R} \cdot E m C_{e q}
$$

O valor adotado para cada crédito de carbono foi de US\$5,00 (R\$ 2,2779). As emissões de carbono equivalente utilizadas são as constantes da TAB. 4.1: $755 \mathrm{gCO}_{2} \mathrm{eq} / \mathrm{kWh}_{\mathrm{El}}\left(0,000755 \mathrm{tCO}_{2} \mathrm{eq} / \mathrm{kwh}_{\mathrm{El}}\right)$ para o diesel. Para a biomassa, adota-se emissões zero, já que a literatura admite que o balanço de emissões na utilização dessa fonte é nulo. 
O custo evitado para o meio ambiente utilizando-se a energia gerada pelo óleo de dendê em substituição ao óleo diesel é obtido pela equação (6.20).

$$
C E_{D}=V E R A_{D}-V E R A_{D I E S E L}
$$

Onde:

$C E_{D}=$ custo evitado pela utilização do óleo de dendê.

Assim, o custo total do empreendimento utilizando óleo de dendê é dado pela equação (6.21). Nessa equação, está inserido o valor da externalidade da fonte de energia em questão.

$$
C T E_{D}=n_{S D} \cdot C T_{D}+C E_{D}
$$

Onde:

$C T E_{D}=$ custo total do empreendimento utilizando óleo de dendê.

O valor do kWh gerado em 20 anos para um sistema utilizando óleo de dendê é obtido pela equação (6.22).

$$
V_{k W h(D)}=\frac{C T E_{D}}{E_{E G 20 a n o s}}
$$

Onde:

$V_{k W h(D)}=$ valor do kWh gerado pelo sistema utilizando óleo de dendê.

A seguir, será descrita a metodologia para o cálculo de viabilidade econômica da energia eólica. 


\section{METODOLOGIA DE CÁLCULO DE VIABILIDADE ECONÔMICA PARA A ENERGIA EÓLICA}

Os cálculos de viabilidade econômica da energia eólica e o dimensionamento do sistema seguem as normas e metodologias já descritas anteriormente, tendo internalizados seus custos ambientais.

Para a fonte de energia eólica, foram considerados sistemas isolados, devido à disponibilidade de turbinas no mercado que são adequadas para esse tipo de empreendimento e que são as mais usadas em todo mundo.

Uma breve descrição da fonte de energia eólica, de suas características e tecnologias será apresentada e, em seguida, são demonstrados os cálculos para a viabilidade desta fonte.

\subsection{Energia Eólica}

A energia eólica tem como origem a radiação solar, já que os ventos são gerados por meio do aquecimento da superfície terrestre de forma não uniforme. Cerca de $2 \%$ da energia solar que chega à superfície terrestre é convertida em energia cinética dos ventos. O comportamento dos ventos é influenciado pelas características topográficas da região, rugosidade, obstáculos e relevo, além da altura do local. Essas características de uma região podem ocasionar a redução ou a aceleração da velocidade do vento (CRESESB, 2013).

Em um sistema de energia eólica, o vento faz girar um rotor composto por lâminas ou pás, conectados a uma haste ligada a várias engrenagens de um gerador elétrico. Em sistemas residenciais, a CC pode ser utilizada diretamente em aparelhos com aquecimento resistivo ou armazenada em baterias. Já nos sistemas de grande porte, o sistema faz uso de um inversor síncrono que converte a CC em CA e a descarrega na frequência correta para a rede. (Hinrichs e Kleinbach, 2003).

De acordo com Hinrichs e Kleinbach (2003), a força que pode ser extraída dos ventos é proporcional ao cubo da velocidade do vento e também à área varrida pelas pás do gerador, que é proporcional ao quadrado do diâmetro da lâmina. A equação que ilustra a máxima produção de energia eólica é dada pela equação (7.1). 
Onde:

$D=$ diâmetro $(\mathrm{m})$;

$v=$ velocidade $\left(\mathrm{m}^{2}\right)$.

A potência disponível a partir dos ventos não pode ser totalmente aproveitada para a geração de eletricidade pelos aerogeradores. Por conta dessa característica física, é adotado o coeficiente de potência $\left(c_{p}\right)$ que é, segundo a CRESESB (2013), a fração da energia eólica que pode ser extraída pelas pás do rotor. Vale salientar que a eficiência máxima de um rotor ideal é de $59 \%$, de acordo com Hinrichs e Kleinbach (2003).

Quanto ao tipo dos aerogeradores, grande parte da experiência mundial é com rotores de eixo horizontal (FIG. 7.1), sendo que os mais utilizados para geração de eletricidade são os geradores horizontais, do tipo hélice, normalmente com três pás (CRESESB, 2013).

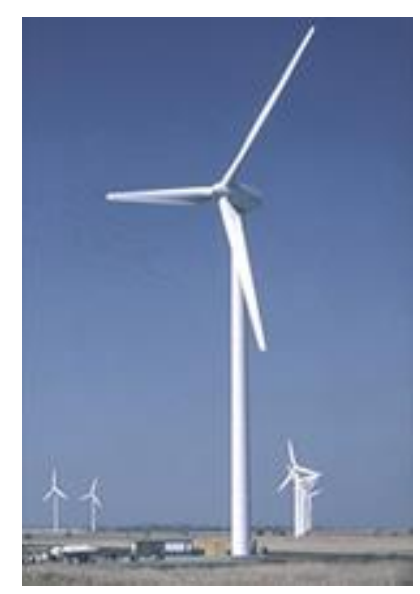

Fonte: CRESESB (2013)

FIGURA 7.1 - Aerogerador de eixo horizontal

Os principais componentes desse tipo de aerogerador são: a torre e a nacelle, que é carcaça montada sobre a torre onde ficam o gerador, a caixa de engrenagens, $O$ sistema de controle e medição do vento. Além desses componentes, há também os motores de rotação do sistema para posicionamento do sistema em relação ao vento e ao rotor (CRESESB, 2013). 
Os sistemas eólicos podem ser aplicados em sistemas isolados, híbridos e interligados à rede. Para esse estudo, serão analisados os sistemas isolados para a geração de eletricidade.

Os sistemas eólicos isolados geralmente utilizam alguma forma de armazenamento de energia, como baterias, e necessitam de um dispositivo de controle de carga, além de um inversor para a alimentação dos equipamentos que operam com CA. A configuração de um sistema eólico isolado é ilustrada na FIG. 7.2.

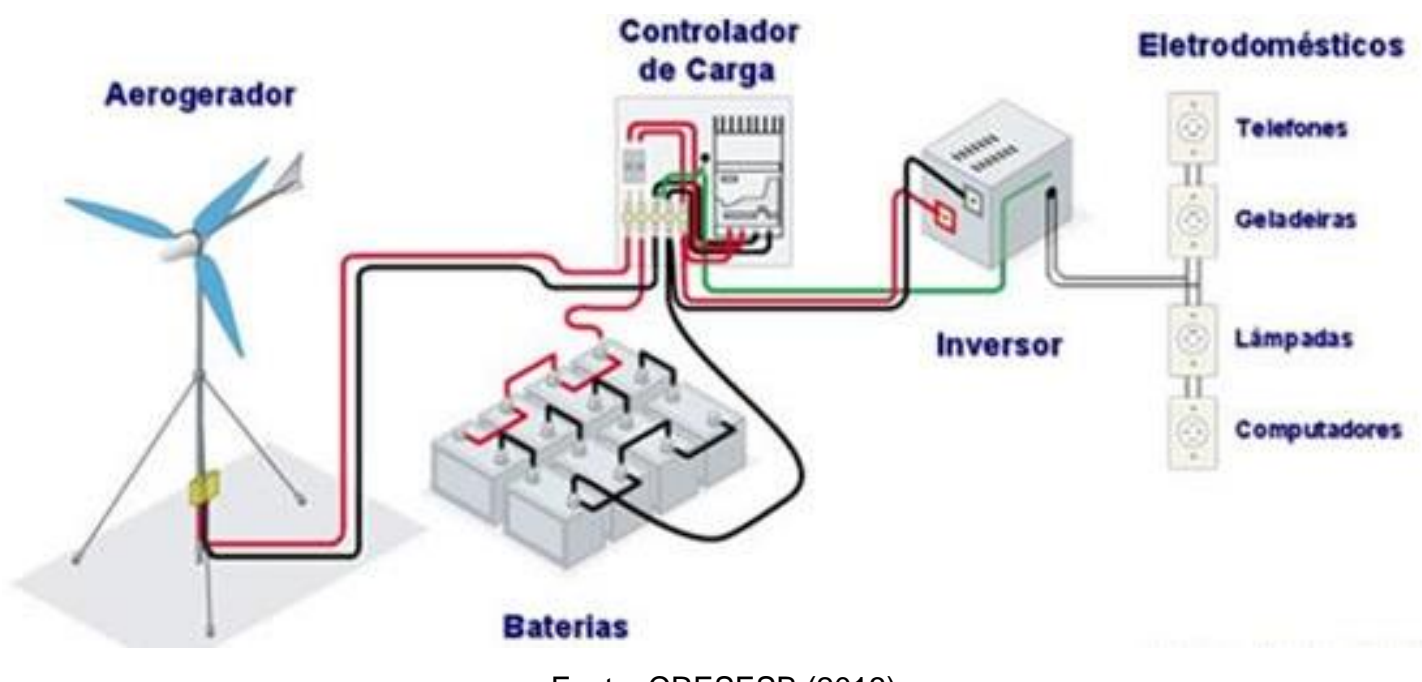

Fonte: CRESESB (2013)

FIGURA 7.2 - Configuração de um sistema eólico isolado

Entre as fontes alternativas de energia elétrica, a energia eólica é a que tem recebido o maior volume de investimentos por conta do PROINFA (2012). De acordo com Pereira et.al. (2006), alguns fatores indicam que a fonte eólica, em médio prazo, poderá ocupar um importante papel como forma de geração de eletricidade descentralizada e complementar no país. Os autores indicam alguns fatores importantes para a concretização dessa tendência: a capacitação tecnológica da indústria nacional e o custo decrescente da eletricidade de origem eólica, associados ao grande potencial eólico existente no país.

Com relação aos impactos ambientais da energia eólica, a literatura sugere que são mínimos, podendo ser resumidos á poluição visual (Hinrichs e Kleinbach, 2003), fato que se aplica para os grandes aerogeradores ou grandes parques eólicos. 
Outro problema que foi vinculado à instalação dos sistemas eólicos inicialmente referia-se ao problema dos pássaros junto às pás do sistema. Contudo, esse problema foi minimizado com o advento das grandes turbinas e as menores velocidades dos rotores que tornam as pás visíveis para os pássaros. Com relação ao ruído causado pelos aerogeradores, as turbinas atendem aos requisitos ambientais e não causam, praticamente, impactos ao meio ambiente. Este fato reduz o tempo de estudos para implementação dos sistemas de geração elétrica (Amarante et al., 2001).

Segundo a Prof. Dra. Eliane Aparecida Faria Amaral Fadigas ${ }^{6}$, professora e pesquisadora do GEPEA - Grupo de Energia do Departamento de Engenharia de Energia e Automação Elétricas da Escola Politécnica da Universidade de São Paulo, para pequenos empreendimentos, que é o escopo dessa dissertação, e para aplicações isoladas, os impactos ambientais produzidos pela fonte eólica são mínimos na geração de energia elétrica. Nesses casos, os impactos ambientais podem ser considerados inexistentes, já que, a grande parte deles é gerada na fase de instalação dos sistemas. Mesmo antes deste tipo de projeto operar, as licenças necessárias já incluem as medidas mitigatórias dos efeitos esperados. Com isso, ao gerar energia, os sistemas isolados não trarão custos ambientais para a sociedade.

Contudo, como já visto anteriormente, Alvim et al. (2010) sugerem um pequeno impacto causado pela fonte eólica, segundo TAB 4.1. Para esse trabalho, então, será considerado o pior cenário possível, com base nos valores de emissão sugeridos por esses autores.

\subsubsection{A energia eólica no Brasil}

O potencial eólico-elétrico brasileiro é descrito na TAB. $7.1 \mathrm{com}$ dados do Atlas do Potencial Eólico Brasileiro.

\footnotetext{
${ }^{6}$ A Prof. Dra. Eliane Aparecida Faria Amaral Fadigas, foi entrevistada na Escola Politécnica da Universidade de São Paulo no dia 26/02/2013.
} 
TABELA 7.1 - Potencial eólico-elétrico estimado do Brasil calculado por integração de área nos mapas temáticos
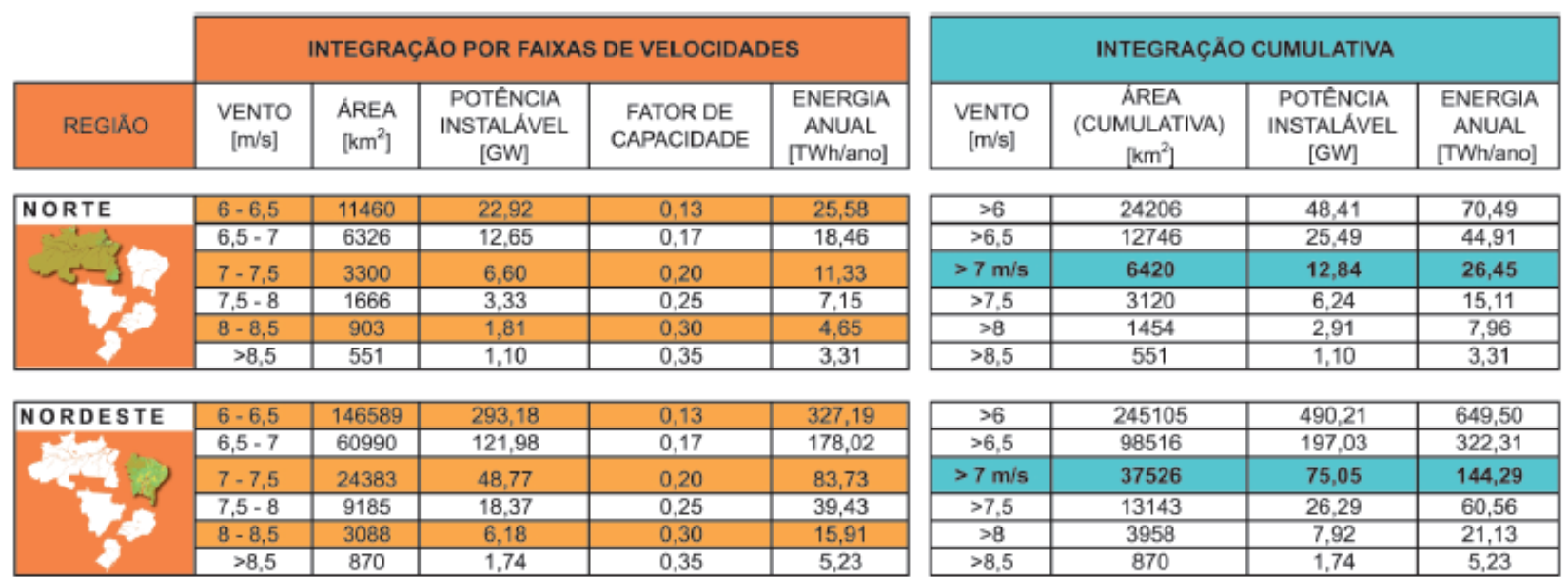

\begin{tabular}{|c|c|c|c|}
\hline$>6$ & 24206 & 48,41 & 70,49 \\
\hline$>6,5$ & 12746 & 25,49 & 44,91 \\
\hline$>7 \mathbf{m} / \mathbf{5}$ & 6420 & 12,84 & 26,45 \\
\hline$>7,5$ & 3120 & 6,24 & 15,11 \\
\hline$>8$ & 1454 & 2,91 & 7,96 \\
\hline$>8,5$ & 551 & 1,10 & 3,31 \\
\hline
\end{tabular}

\begin{tabular}{|c|c|c|c|c|c|}
\hline CENTRO-OESTE & $6-6,5$ & 41110 & 82,22 & 0,13 & 91,76 \\
\cline { 2 - 6 } & $6,5-7$ & 8101 & 16,20 & 0,17 & 23,65 \\
\cline { 2 - 6 } & $7-7,5$ & 1395 & 2,79 & 0,20 & 4,79 \\
\cline { 2 - 6 } & $7,5-8$ & 140 & 0,28 & 0,25 & 0,60 \\
\cline { 2 - 6 } & $8-8,5$ & 6 & 0,01 & 0,30 & 0,03 \\
\cline { 2 - 6 } & $>8,5$ & 0 & 0,00 & 0,35 & 0,00 \\
\hline \multirow{3}{*}{} & \multicolumn{3}{|c|}{} \\
\hline
\end{tabular}

\begin{tabular}{|c|c|c|c|}
\hline$>6$ & 245105 & 490,21 & 649,50 \\
\hline$>6,5$ & 98516 & 197,03 & 322,31 \\
\hline$>7 \mathrm{~m} / \mathrm{s}$ & 37526 & 75,05 & 144,29 \\
\hline$>7,5$ & 13143 & 26,29 & 60,56 \\
\hline$>8$ & 3958 & 7,92 & 21,13 \\
\hline$>8,5$ & 870 & 1,74 & 5,23 \\
\hline
\end{tabular}

\begin{tabular}{|c|c|c|c|c|c|}
\hline SUDESTE & $6-6,5$ & 114688 & 229,38 & 0,13 & 255,99 \\
\cline { 2 - 6 } & $6,5-7$ & 46302 & 92,60 & 0,17 & 135,15 \\
\cline { 2 - 6 } & $7-7,5$ & 11545 & 23,09 & 0,20 & 39,64 \\
\cline { 2 - 6 } & $7,5-8$ & 2433 & 4,87 & 0,25 & 10,44 \\
\cline { 2 - 6 } & $8-8,5$ & 594 & 1,19 & 0,30 & 3,06 \\
\cline { 2 - 6 } & $>8,5$ & 297 & 0,59 & 0,35 & 1,78 \\
\hline
\end{tabular}

\begin{tabular}{|c|c|c|c|}
\hline$>6$ & 50752 & 101,50 & 120,83 \\
\hline$>6,5$ & 9642 & 19,28 & 29,07 \\
\hline$>7 \mathrm{~m} / \mathrm{s}$ & 1541 & 3,08 & 5,42 \\
\hline$>7,5$ & 146 & 0,29 & 0,63 \\
\hline$>8$ & 6 & 0,01 & 0,03 \\
\hline$>8,5$ & 0 & 0,00 & 0,00 \\
\hline
\end{tabular}

\begin{tabular}{|c|c|r|c|c|c|}
\hline SUL & $6-6,5$ & 121798 & 243,60 & 0,13 & 271,86 \\
\hline & $6,5-7$ & 38292 & 76,58 & 0,17 & 111,77 \\
\hline & $7-7,5$ & 9436 & 18,87 & 0,20 & 32,40 \\
\hline \multirow{3}{*}{7} & $7,5-8$ & 1573 & 3,15 & 0,25 & 6,75 \\
\cline { 2 - 6 } & $8-8,5$ & 313 & 0,63 & 0,30 & 1,61 \\
\cline { 2 - 6 } & $>8,5$ & 57 & 0,11 & 0,35 & 0,34 \\
\hline
\end{tabular}

\begin{tabular}{|c|c|c|c|}
\hline$>6$ & 175859 & 351,72 & 446,07 \\
\hline$>6,5$ & 61171 & 122,34 & 190,08 \\
\hline$>7$ m/5 & 14869 & 29,74 & 54,93 \\
\hline$>7,5$ & 3324 & 6,65 & 15,29 \\
\hline$>8$ & 891 & 1,78 & 4,84 \\
\hline$>8,5$ & 297 & 0,59 & 1,78 \\
\hline
\end{tabular}

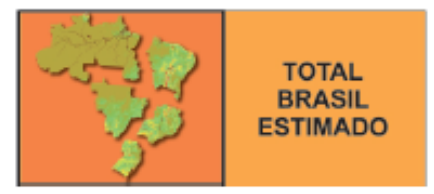

\begin{tabular}{|c|c|c|c|}
\hline$>6$ & 171469 & 342,94 & 424,74 \\
\hline$>6,5$ & 49671 & 99,34 & 152,88 \\
\hline$>7 \mathbf{~ m / s}$ & 11379 & 22,76 & 41,11 \\
\hline$>7,5$ & 1943 & 3,89 & 8,71 \\
\hline$>8$ & 370 & 0,74 & 1,95 \\
\hline$>8,5$ & 57 & 0,11 & 0,34 \\
\hline
\end{tabular}

\begin{tabular}{|c|c|c|c|}
\hline$>6$ & 667391 & 1334,78 & 1711,62 \\
\hline$>6,5$ & 231746 & 463,49 & 739,24 \\
\hline$>7 \mathrm{~m} / \mathrm{s}$ & 71735 & 143,47 & 272,20 \\
\hline$>7,5$ & 21676 & 43,35 & 100,30 \\
\hline$>8$ & 6679 & 13,36 & 35,93 \\
\hline$>8,5$ & 1775 & 3,55 & 10,67 \\
\hline
\end{tabular}

Fonte: Amarante et al., 2001.

Os dados sintetizados na TAB. 7.1 foram encontrados a partir da integração dos mapas digitais considerando: velocidades médias anuais iguais ou superiores a $6 \mathrm{~m} / \mathrm{s}$; curvas de desempenho de turbinas eólicas em torres de $50 \mathrm{~m}$ de altura; densidade média de ocupação do terreno de $2 \mathrm{MW} / \mathrm{km}^{2}$ e fator de disponibilidade de 0,98, considerado típico para usinas eólicas comerciais (Amarante et al., 2001).

O potencial total estimado para a geração eólica no Brasil é da ordem de $143 \mathrm{GW}$, gerando 272,20 TWh/ano. 
Na FIG. 7.3 são descritos os potenciais de geração da energia eólica no Brasil por região considerando-se ventos a 50 metros de altura.

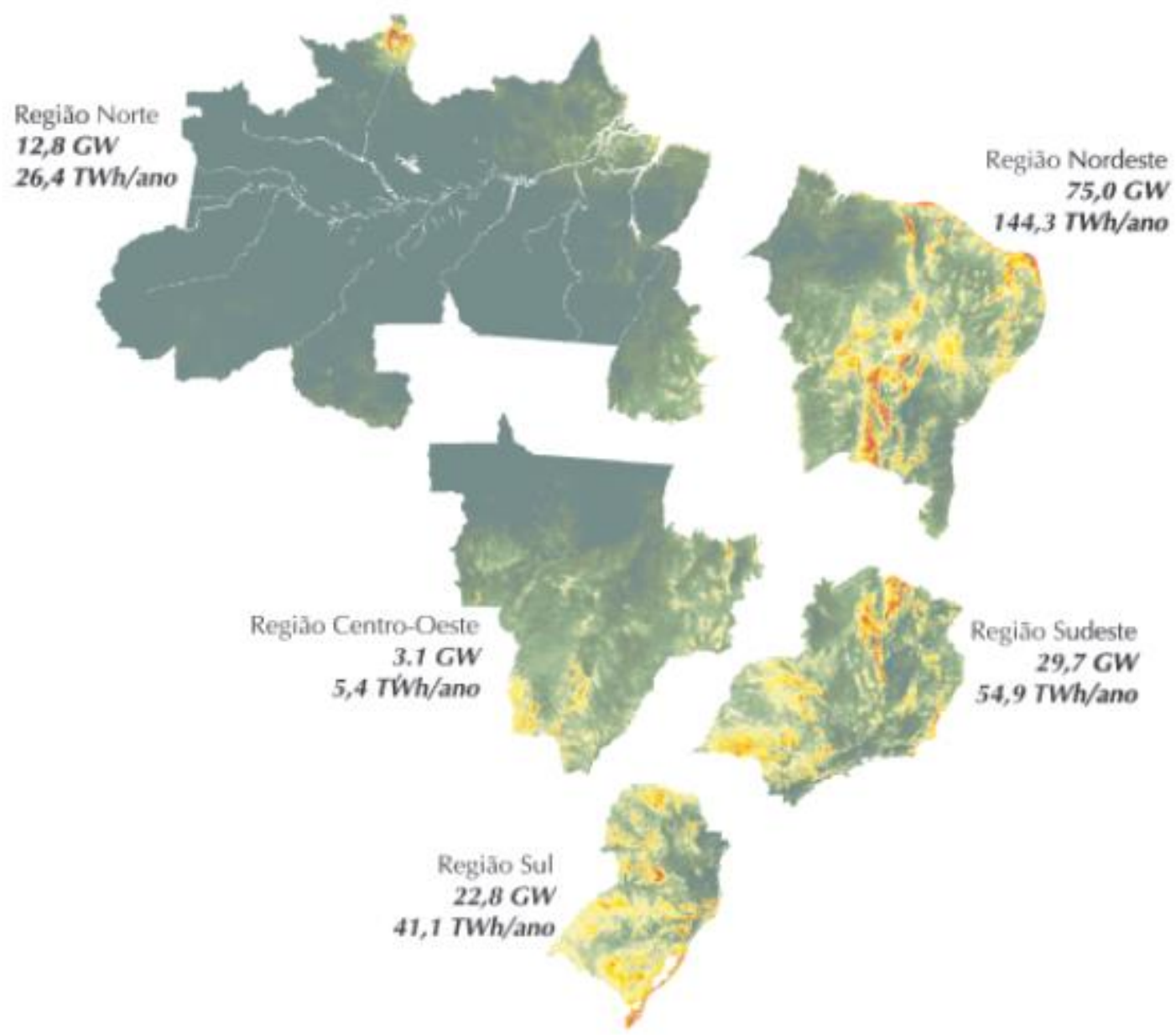

Fonte: Amarante et al., 2001.

FIGURA 7.3 - Potencial eólico estimado por região do Brasil

Do total estimado para a geração eólica no Brasil, verifica-se que o potencial de geração, a partir da energia dos ventos na região nordeste brasileira, é de $75 \mathrm{GW}$ ou 144,3 TWh/ano, quando considerados os ventos médios de $7 \mathrm{~m} / \mathrm{s}$ a 50m de altura, de acordo com a TAB. 7.1 e a FIG. 7.3. Esse é o maior potencial do país, respondendo por $52,3 \%$ do potencial total estimado para a geração de eletricidade proveniente da energia eólica no país. Os dados demonstram que essa região é um ponto estratégico para a implementação desse tipo de tecnologia para a geração de eletricidade no Brasil. 
O ANEXO C apresenta os mapas do potencial eólico brasileiro anual, da velocidade média anual do vento a 50 metros de altura, dados em $\mathrm{m} / \mathrm{s}$, e também o mapa do potencial eólico da região nordeste brasileira.

De acordo com o Balanço Energético Nacional (BEN) de 2012, com ano base 2011 (EPE, 2012a), a produção de eletricidade a partir de fontes eólicas foi de $2.705 \mathrm{GWh}$, 24\% maior que no ano anterior, quando a produção foi de 2.177 GWh. Em 2011, a potência instalada para geração eólica aumentou 53,7\% quando comparada a 2010, chegando ao valor de 1.426 MW de potência instalada. A TAB. 7.2 mostra a evolução da produção e do consumo de energia eólica no Brasil entre os anos de 2002 e 2011.

TABELA 7.2 - Evolução da produção e do consumo de energia eólica no Brasil (GWh)

\begin{tabular}{c|c|c|c|c|c|c|c|c|c|c}
\hline Ano & 2002 & 2003 & 2004 & 2005 & 2006 & 2007 & 2008 & 2009 & 2010 & 2011 \\
\hline $\begin{array}{c}\text { Geração } \\
\text { total }\end{array}$ & 56 & 63 & 74 & 74 & 342 & 668 & 1183 & 1238 & 2177 & 2705 \\
\hline $\begin{array}{c}\text { Consumo } \\
\text { total }\end{array}$ & 56 & 63 & 74 & 74 & 342 & 668 & 1183 & 1238 & 2177 & 2705 \\
\hline
\end{tabular}

*Para estimar os dados não informados, foi considerado o fator de capacidade médio do parque eólico nacional de 32,0\%.

Fonte: EPE, 2012.

É notável a evolução da geração de energia a partir de fonte eólica no país entre os anos de 2002 e 2011, ou seja, a geração total a partir desta fonte aumentou mais de 48 vezes entre os anos de referência. Um aumento de aproximadamente $4.830 \%$.

Esse grande aumento deve-se, em grande parte, ao PROINFA, um programa pioneiro que impulsionou algumas fontes alternativas para geração de energia, dando um maior incentivo à energia eólica. (PROINFA, 2012).

\subsubsection{Viabilidade econômica da energia eólica considerando seus custos ambientais}

De acordo com Blasques et al. (2005), a geração de um sistema eólico pode ser obtido de acordo com a equação (7.2). O fator de capacidade médio é de $30 \%$ para esses sistemas.

$$
E_{E O L}=P \cdot \Delta T \cdot C
$$


Onde:

$E_{E O L}=$ energia elétrica gerada pelo sistema $(\mathrm{kWh})$;

$\Delta T=$ tempo $(\mathrm{h})$;

$P=$ potência nominal do sistema eólico (w ou kW);

$C=$ fator de capacidade do sistema.

Nesse estudo, a equação para o cálculo da energia é fornecida para que os usuários do programa PEASEB possam fazer seus cálculos de forma independente para os seus projetos de sistemas eólicos. Alguns fabricantes já fornecem o valor da energia gerada para seus específicos sistemas. Nesse trabalho, a energia gerada foi fornecida pelo fabricante.

Optou-se, então, pela utilização de geradores que fornecem 40 kWh/mês de energia, que são os geradores disponíveis na faixa de geração estipulada para o trabalho.

Segundo Dutra e Tolmasquim (2002), a energia gerada para um sistema deve considerar o seu tempo de vida, estimado em 20 anos, pois esse é o tempo de vida útil das turbinas, e pode ser obtida por (7.3):

$$
E_{\text {Eol20anos }}=E_{E o l M} \cdot n_{m} \cdot n_{a}
$$

Onde:

$E_{\text {Eol20anos }}=$ energia eólica gerada por um sistema em 20 anos (kWh);

$n_{m}=$ número de meses;

$n_{a}=$ número de anos.

Dessa forma, então, a energia gerada por um sistema eólico durante seu tempo estimado de vida útil é de:

$$
E_{\text {Eol20anos }}=9.600 \mathrm{kWh}
$$

A partir do montante mensal produzido por cada sistema eólico será calculado o número de sistemas necessários para o atendimento de cada 
município. Para o sistema eólico, cada família receberá mensalmente $40 \mathrm{kWh}$ devido às limitações técnicas já mencionadas e, nesse caso, os sistemas serão isolados. Assim, o número de sistemas eólicos $\left(n_{\text {SEol }}\right)$ necessários será igual ao número de famílias constituídas por 5 componentes, em média. Para se obter o número de sistemas eólicos, divide-se a população total por 5 .

A partir da determinação do número de sistemas a serem implementados, é possível obter a quantidade de energia que será efetivamente gerada no município, durante toda a vida útil dos sistemas eólicos que atenderão o número de famílias calculadas a partir da projeção o IBGE. Esse número é calculado pela da equação (7.4). Esse dado será necessário para a valoração das externalidades.

$$
E_{\text {Eol(EG)20anos }}=n_{S E o l} \cdot E_{\text {Eol20anos }}
$$

Onde:

$E_{E o l(E G) 20 a n o s}=$ energia efetivamente gerada no município em 20 anos.

Os custos totais do sistema devem considerar: os custos iniciais de implantação $(\mathrm{Cl})$ necessários para a operação do sistema de energia; os custos de reposição $(\mathrm{CR})$ dos principais componentes do sistema devido à sua vida útil; os custos de operação (CO) necessários ao funcionamento do sistema, sendo considerados basicamente o custo dos combustíveis e o custo de manutenção (CM) preventiva e corretiva. Assim, o Custo Total de um sistema eólico pode ser obtido por (7.5) (Blasques et al., 2005).

$$
C T_{E o l}=C I+C R+C O+C M
$$

Para determinar o custo dos sistemas, os cálculos levam em consideração o tempo de vida estimado dos sistemas eólicos. O sistema utilizado para esse trabalho é um sistema Off-Grid (desconectado da rede, ou seja, geração descentralizada) (FIG. 7.5). 


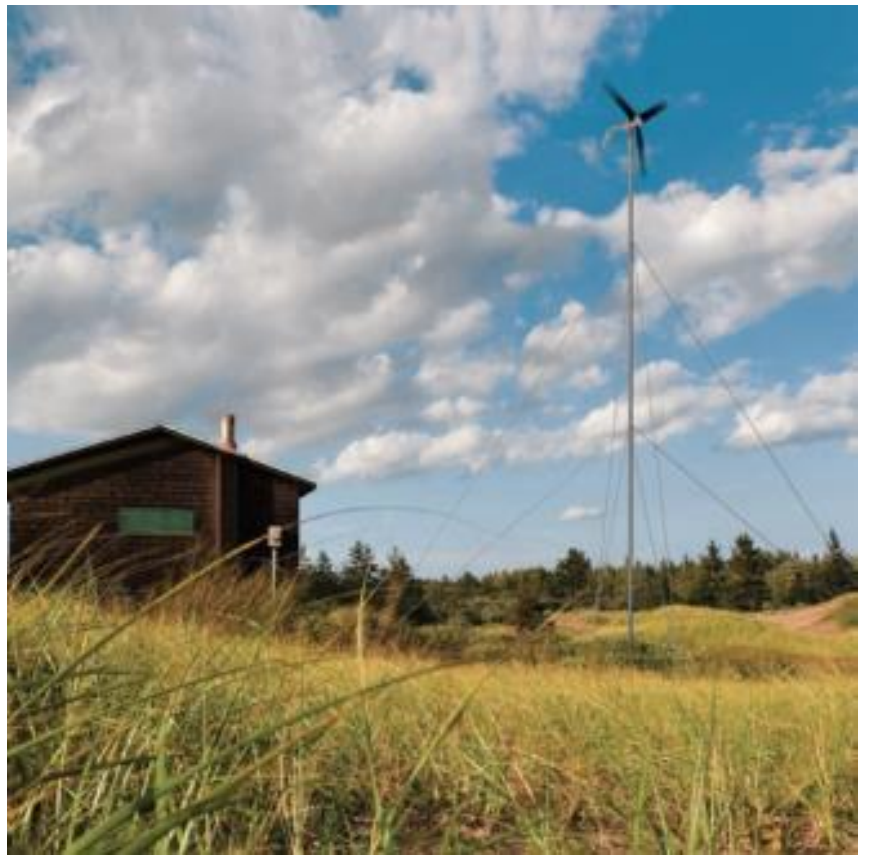

Fonte: Energia Pura (2013)

FIGURA 7.4 - Sistema eólico isolado

Fazem parte desse sistema: um aerogerador completo com controlador de carga interno, vento para início de geração de $2,68 \mathrm{~m} / \mathrm{s}$, potência nominal de 160 watts a $12,5 \mathrm{~m} / \mathrm{s}$ (300 W pico), controlador da turbina por microprocessador regulador interno inteligente. Sua capacidade de geração é de $40 \mathrm{kWh} / \mathrm{mês}$. De acordo com as especificações técnicas do fabricante e do revendedor, o aerogerador não necessita de manutenção, e o seu valor unitário é de $R \$$ 3.543,00. Também, segundo o fabricante e o revendedor, duas baterias estacionárias de 220 Ah com 5 anos de vida útil são utilizadas. $O$ valor unitário da bateria é de $R \$ 1.216,00$ (Energia Pura, 2013).

Além desses componentes, é necessária a instalação de um inversor de potência. O tempo de vida médio de um inversor é de aproximadamente 10 anos, de acordo com Shayani et al. (2006), e o custo unitário desse componente, segundo a Kyocera Solar do Brasil (2012), é de $\mathrm{R} \$ 3.237,63$.

Assim, a partir das especificações do sistema, é possível determinar algumas premissas para o cálculo de custos do sistema eólico. São necessárias apenas 3 reposições de baterias durante a vida útil do sistema, que serão incluídas em CR. Não haverá CO já que, como descrito anteriormente, esse custo refere-se basicamente ao custo ligado ao combustível, e não se aplica à energia eólica. E, finalmente, o CM será inexistente, pois o fabricante e o revendedor 
atestam que não há necessidade de manutenção do aerogerador durante a vida útil do equipamento. Com base nessas informações, o cálculo do custo do sistema eólico será reduzido (equação 7.5), apenas para o custo de instalação e reposição (equação 7.6).

$$
C T_{E o l}=C I+C R
$$

Então, o Custo Total do sistema pode ser dado por (7.7):

$$
C T_{E o l}=\left[\left(1 \cdot V_{\text {Aero }}\right)+\left(2 \cdot V_{B}\right)+\left(1 \cdot V_{I}\right)\right]+\left[3\left(2 \cdot V_{B}\right)+\left(1 \cdot V_{I}\right)\right]
$$

Onde:

$V_{\text {Aero }}=$ valor do aerogerador;

$V_{B}=$ valor da bateria;

$V_{I}=$ valor do inversor.

Assim, o valor de um sistema eólico, durante 20 anos, é de:

$$
C T_{E o l}=19.746,26(\mathrm{R} \$)
$$

A partir dos dados referentes à geração e ao custo dos sistemas, é possível obter o valor do custo ambiental do sistema de energia eólica. Para a energia dos ventos, esses custos serão avaliados a partir do custo evitado, por meio da substituição do óleo diesel pela energia eólica, considerando a possibilidade da venda de créditos de carbono. Então, o VERA do diesel e 0 VERA da energia eólica podem ser calculados pela equação (7.8).

$$
V E R A=E_{E o l(E G) 20 a n o s} \cdot V_{C E R} \cdot E m C_{e q}
$$

Onde:

$V E R A$ = valor econômico do recurso ambiental ar poluído;

$V_{C E R}=$ valor do crédito de carbono; 
$E m C_{e q}=$ emissões de carbono equivalente.

O valor adotado para cada crédito de carbono foi de US\$5,00 (R\$ 2,2779). As emissões de carbono equivalente utilizadas para os cálculos são as constantes da TAB. 4.1: $\left.755 \mathrm{gCO}_{2} \mathrm{eq} / \mathrm{kWh} \mathrm{EI}_{\left(0,000755 \mathrm{tCO}_{2} \mathrm{eq} / \mathrm{kwh}\right.}\right)$ para o diesel e $5,4 \mathrm{gCO}_{2} \mathrm{eq} / \mathrm{kWh}_{\mathrm{El}}\left(0,0000054 \mathrm{tCO}_{2} \mathrm{eq} / \mathrm{kwh}_{\mathrm{EI}}\right)$, para energia eólica.

O custo evitado para o meio ambiente utilizando a energia eólica em substituição ao óleo diesel é obtido pela equação (7.9).

$$
C E_{E o l}=V E R A_{E o l}-V E R A_{D I E S E L}
$$

Onde:

$C E_{E o l}=$ custo evitado pela utilização da energia eólica.

Assim, o custo total do empreendimento utilizando energia eólica é dado pela equação (7.10).

$$
C T E_{E o l}=n_{S E o l} \cdot C T_{E o l}+C E_{E o l}
$$

Onde:

$C T E_{E o l}=$ custo total do empreendimento utilizando energia eólica.

O valor do kWh gerado em 20 anos para um sistema de energia eólica é obtido pela equação (7.11).

$$
V_{k W h(E o l)}=\frac{C T E_{E o l}}{E_{E o l(E G) 20 a n o s}}
$$

Onde:

$V_{k W h(E o l)}=$ valor do kWh gerado pelo sistema de energia eólica. 
Após o equacionamento dos custos de todas as fontes aqui analisadas, o programa PEASEB foi reprogramado com as atualizações realizadas.

A seguir, será feita a descrição da nova versão do programa e de suas funcionalidades para cada uma das fontes de energia estudadas. 


\section{O PROGRAMA PEASEB}

O PEASEB, desenvolvido no trabalho de Vanni (2008), teve como objetivo calcular os custos das fontes de energia solar, eólica e biomassa. No entanto, no trabalho original, não foram realizados os cálculos de custo ambiental, que é o objeto desse trabalho.

Este capítulo apresenta as modificações realizadas na versão original do programa, o seu funcionamento e as telas de interfaces. Uma breve orientação sobre como utilizá-lo será fornecida ao usuário.

\subsection{O programa PEASEB/v2}

Para o desenvolvimento do programa PEASEB/v2, foi utilizada a linguagem de programação VBA (Visual Basic for Application) combinada com a Microsoft Excel. Esse programa calcula os custos e a produção de um sistema de energia elétrica para as condições sugeridas pelo usuário, pois os valores iniciais são fornecidos como dados de entrada. O programa foi desenvolvido para ser o mais amigável possível e de fácil utilização.

A principal alteração feita no programa original foi a inserção dos cálculos dos custos ambientais para cada uma das fontes estudadas nesse trabalho. Na primeira versão do programa, o custo ambiental foi considerado um percentual fixo para todas as fontes avaliadas, o que elevava o valor final do empreendimento em $10 \%$, pois se admitiu uma externalidade negativa. No entanto, a adequação do modelo proposto nesse trabalho trará maior veracidade aos resultados, ou seja, o conhecimento dos reais custos de cada fonte facilitará a tomada de decisão.

A partir do equacionamento das fontes alternativas de energia aqui estudadas, foram consideradas duas novas configurações para energia solar e de biomassa. Nesse trabalho, foram propostas as fontes solar em minirredes e a de biomassa com resíduos agrícolas, cujos cálculos foram inseridos na nova versão do PEASEB/v2. A FIG. 8.1 mostra as novas telas de abertura do programa que foram adequadas para atender os cálculos da viabilidade econômica, levando em conta os custos evitados para as fontes alternativas de energia consideradas e suas novas configurações. 
O usuário do PEASEB/v2 deverá ter conhecimento prévio da localização do empreendimento e das necessidades de geração de energia para região estudada, a fim de fornecer de forma correta os dados de entrada para o programa. Embora o Maranhão tenha sido o estado analisado no trabalho original, esse estudo foi estendido para toda a região nordeste do Brasil, utilizando as informações da disponibilidade média das fontes da região.

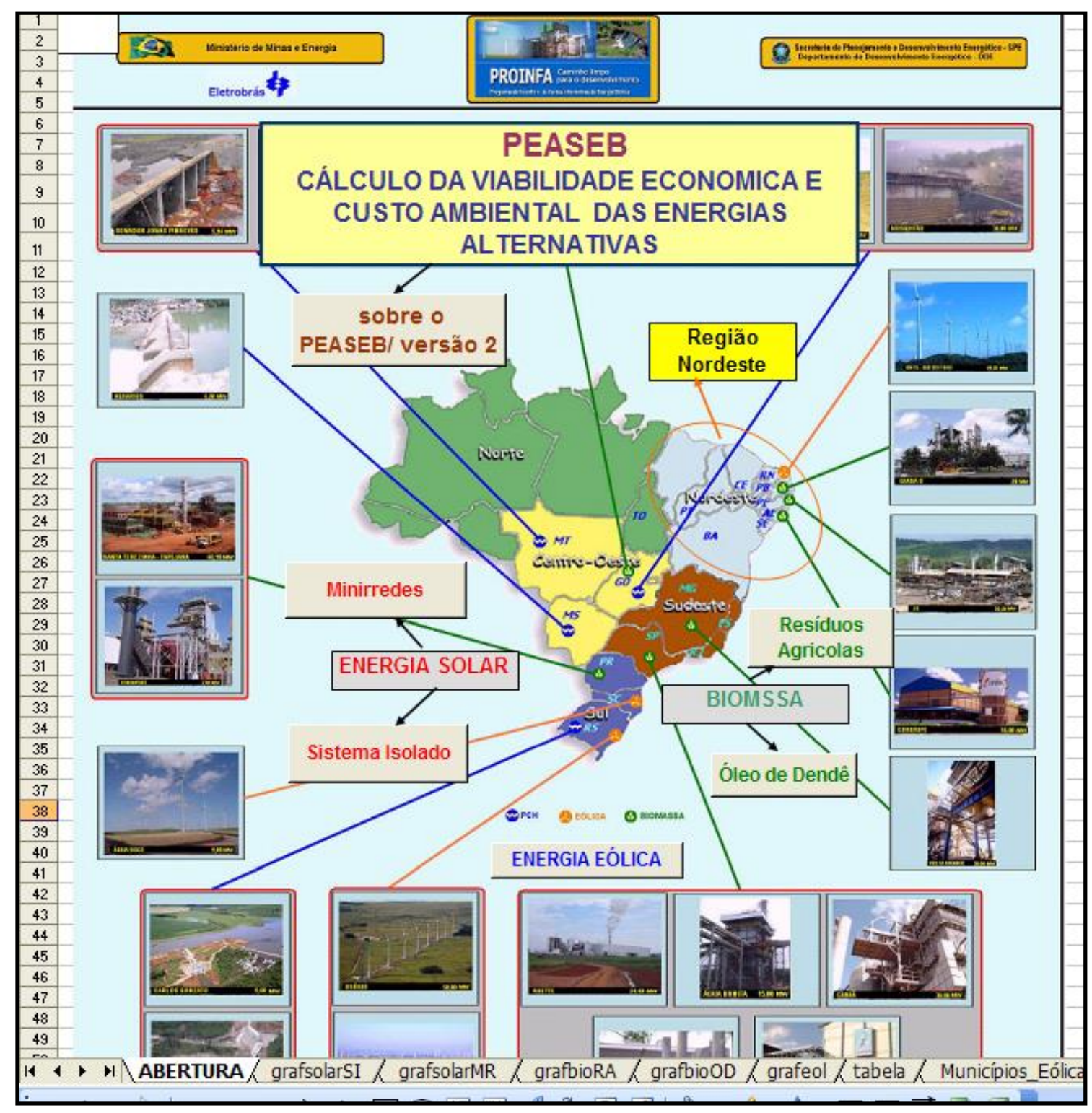

FIGURA 8.1 - Tela de abertura do PEASEB/v2

O PEASEB/v2 foi reprogramado levando em consideração as equações definidas nos capítulos 5, 6 e 7, que são relativas a cada uma das fontes alternativas de energia abordadas nesse trabalho. 


\subsubsection{Energia solar fotovoltaica no PEASEB/v2}

Ao utilizar esse programa para os cálculos da energia solar, o usuário deverá clicar no botão "Sistema Isolado" ou no botão "Minirredes", seguindo os passos:

- clicar na planilha "ABERTURA" do programa PEASEB/v2;

- para calcular um dos sistemas para energia solar, o usuário deverá clicar no índice, no botão: "Sistema Isolado" ou "Minirredes", onde haverá um link para outra pasta de trabalho, denominada de "Cálculo de Viabilidade Econômica - Energia Solar" ou para o "Sistema Isolado" ou em "Minirredes", onde são inseridos os dados de entrada;

- o resumo dos custos da energia solar para uma das duas opções de sistema gerado pelo programa será direcionado para a pasta "tabela" ;

- os gráficos dos custos da energia solar para cada um dos sistema, gerado pelo programa, serão direcionados para as pastas "grafesolarSI", para o sistema isolado, e "grafesolarMR", para o sistema em minirredes.

Para exemplificar o uso do programa, a sua utilização será demonstrada na FIG. 8.2.. Se o usuário clicar no botão "Sistema Isolado", será remetido, por meio de um link, para outra tela de trabalho, denominada de "Cálculo da Viabilidade Econômica - Sistema Isolado". Nessa tela, o usuário fornecerá alguns dados para o cálculo da viabilidade econômica considerando o custo ambiental dessa fonte. A FIG. 8.2 apresenta os campos preenchidos e os cálculos do custo total do empreendimento para o sistema isolado, para um determinado município do Nordeste, onde o custo evitado foi internalizado no custo final. Os dados dos componentes utilizados para os cálculos e os dados operacionais foram fornecidos no capítulo 5 . 


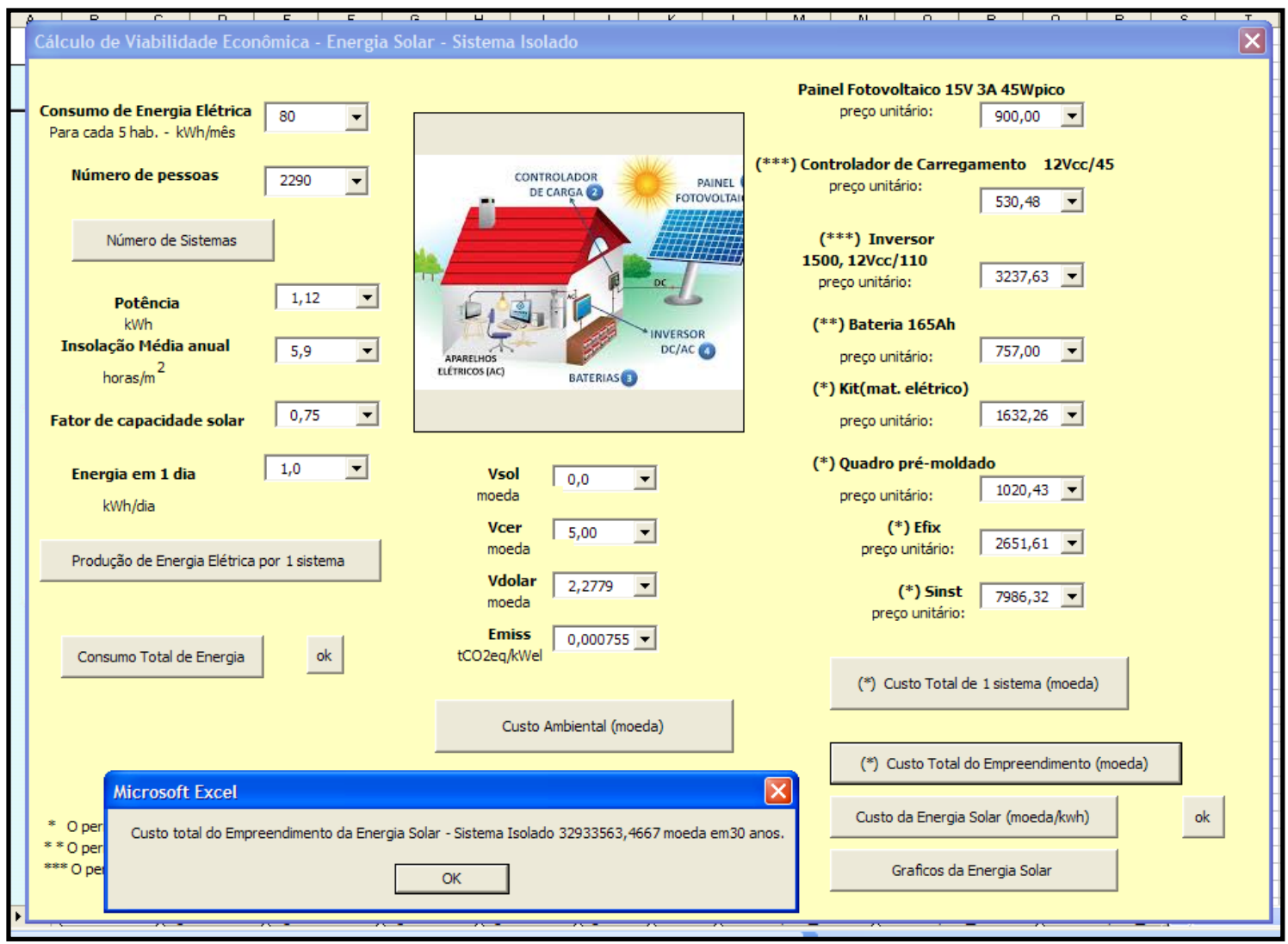

FIGURA 8.2 - Cálculo da Viabilidade Econômica para Solar - Sistema Isolado

O usuário também poderá preencher os campos solicitados com as informações dos componentes com valores atualizados e com outros valores de consumo de energia, insolação média anual e fator de capacidade, além dos dados para o cálculo do custo evitado, lembrando que o sistema deverá ter a mesma configuração apresentada no capítulo 5 .

A pasta "tabela" contém um resumo dos cálculos da viabilidade econômica da energia solar - sistema isolado, dados estes gerados pelo PEASEB/v2 (FIG 8.3).

A FIG. 8.4 apresenta a pasta "grafsolarSl" com os gráficos para o sistema isolado dos custos: total do empreendimento, de um sistema e por kWh, todos na moeda adotada em função do número de habitantes dos municípios selecionados. 


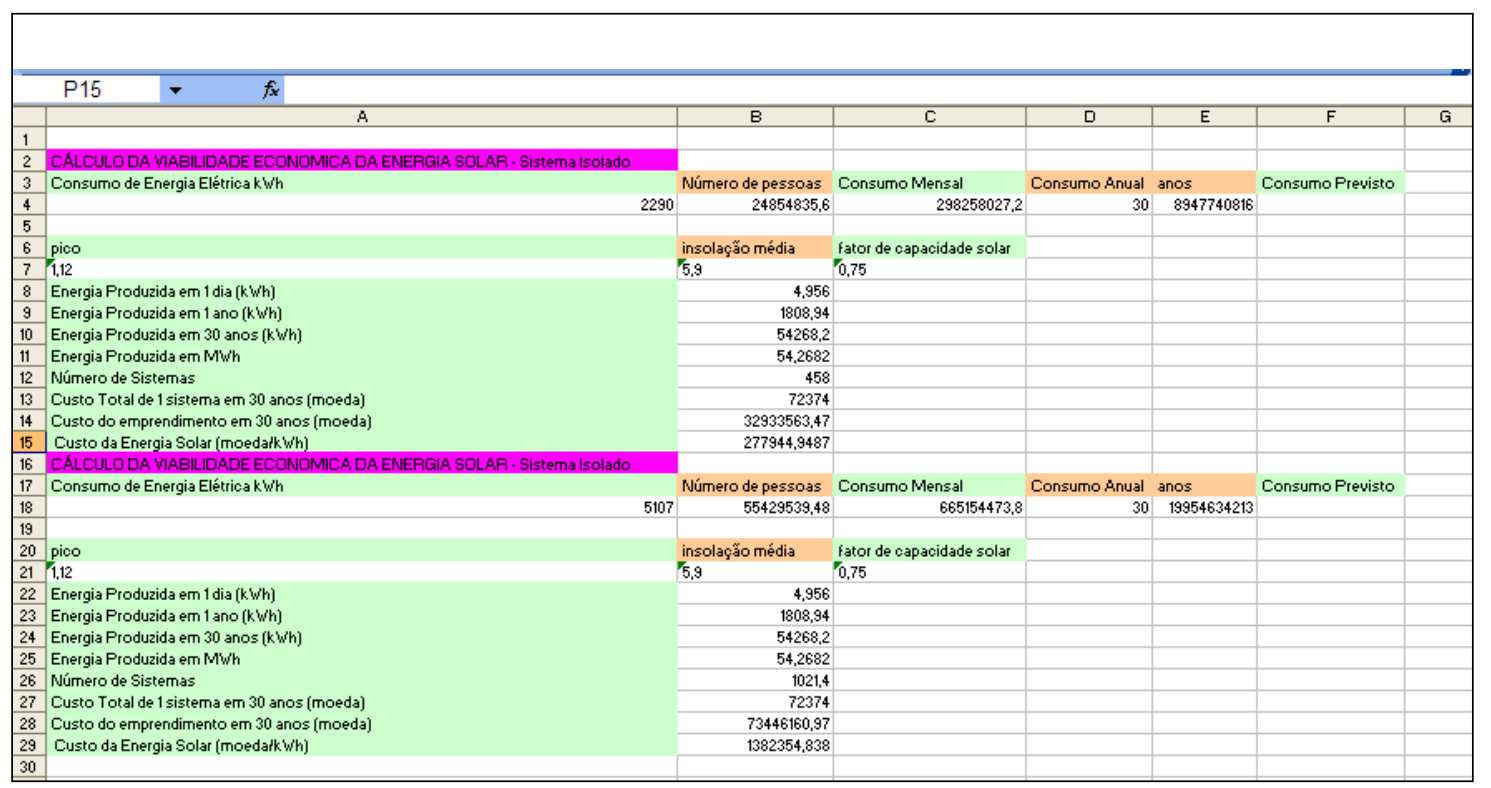

FIGURA 8.3 - Tabela para a Energia Solar - Sistema Isolado

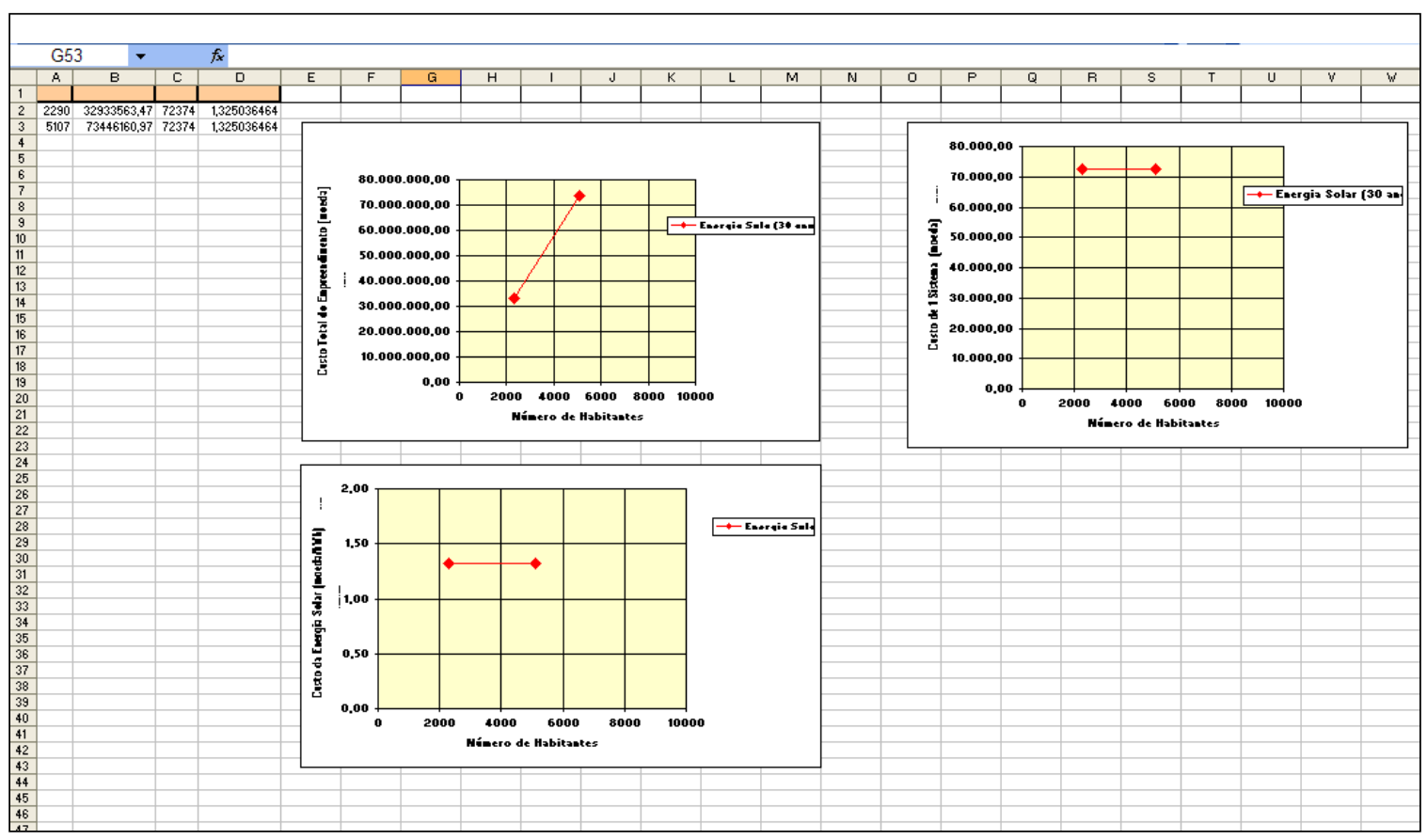

FIGURA 8.4 - GRAFSOLARSI : Solar - Sistema Isolado

O APÊNDICE C apresenta a listagem da programação feita em VBA apenas para o cálculo dos custos para a fonte de energia solar em sistema isolado, pois no caso das minirredes, da energia da biomassa em suas duas configurações e da energia eólica, a programação é semelhante.

No caso da energia em minirredes, será apresentada apenas a tela de entrada, lembrando que, para acessá-la, o usuário deverá clicar no botão "Minirredes", que tem um link para outra pasta de trabalho, denominada de 
"Cálculo de Viabilidade Econômica - Energia Solar - Minirredes", como pode ser observado na FIG. 8.5. O usuário poderá utilizar os valores default, que estão na própria tela, ou utilizar os valores atualizados para a mesma configuração sugerida no trabalho. Nesse caso, também são gerados pelo programa: a pasta "tabela", com os principais cálculos e uma pasta de gráficos "grafsolarMR", com os gráficos do custo do empreendimento, considerando o custo evitado, o custo de um sistema e o custo por kWh, todos em função do número de habitantes para um município estudado.

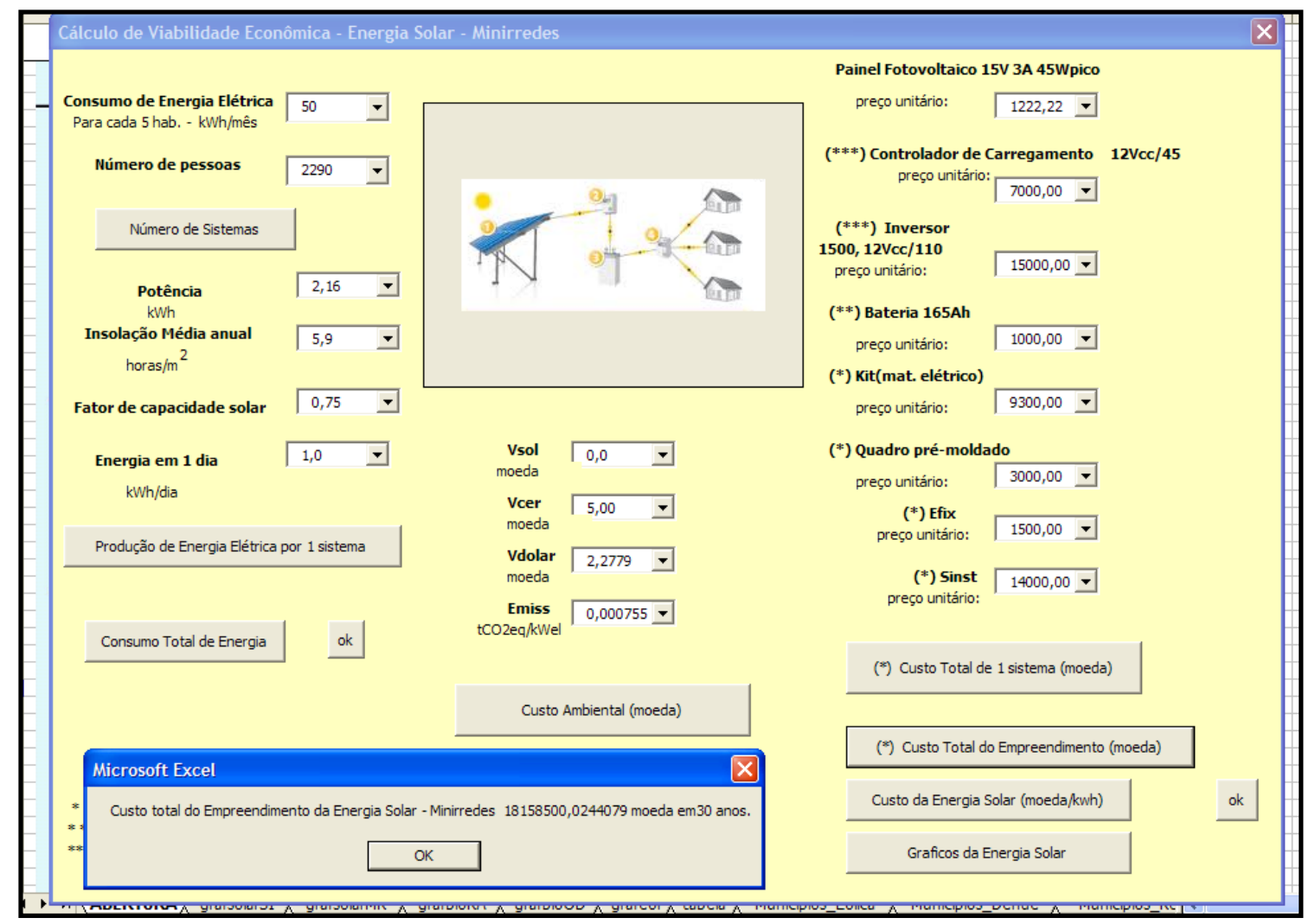

FIGURA 8.5 - Cálculo da Viabilidade Econômica para Solar - Minirredes

$\mathrm{Na}$ sequência, serão apresentadas apenas as telas de entrada para cada uma das outras fontes de energia estudadas, embora em todas elas sejam também geradas as pastas com os principais cálculos e os gráficos dos custos.

\subsubsection{A energia da Biomassa no PEASEB/v2}

Ao utilizar o programa PEASEB/v2 para o cálculo dos custos das biomassas de resíduos agrícolas ou de óleo de dendê, o usuário deverá clicar no índice, no botão "Resíduos Agrícolas" ou no botão "Óleo de Dendê". 
Se a opção for "Resíduos Agrícolas", o botão tem um link para outra pasta de trabalho, denominada de "Cálculo da Viabilidade Econômica da Biomassa - Resíduos Agrícolas", como pode ser observado na FIG. 8.6. Além dos dados operacionais da instalação, o usuário também deverá fornecer os valores unitários na moeda desejada de cada um dos componentes do sistema, como também as informações para o cálculo do custo evitado na moeda desejada. Nesse caso, foram utilizadas as informações fornecidas no Capítulo 6.

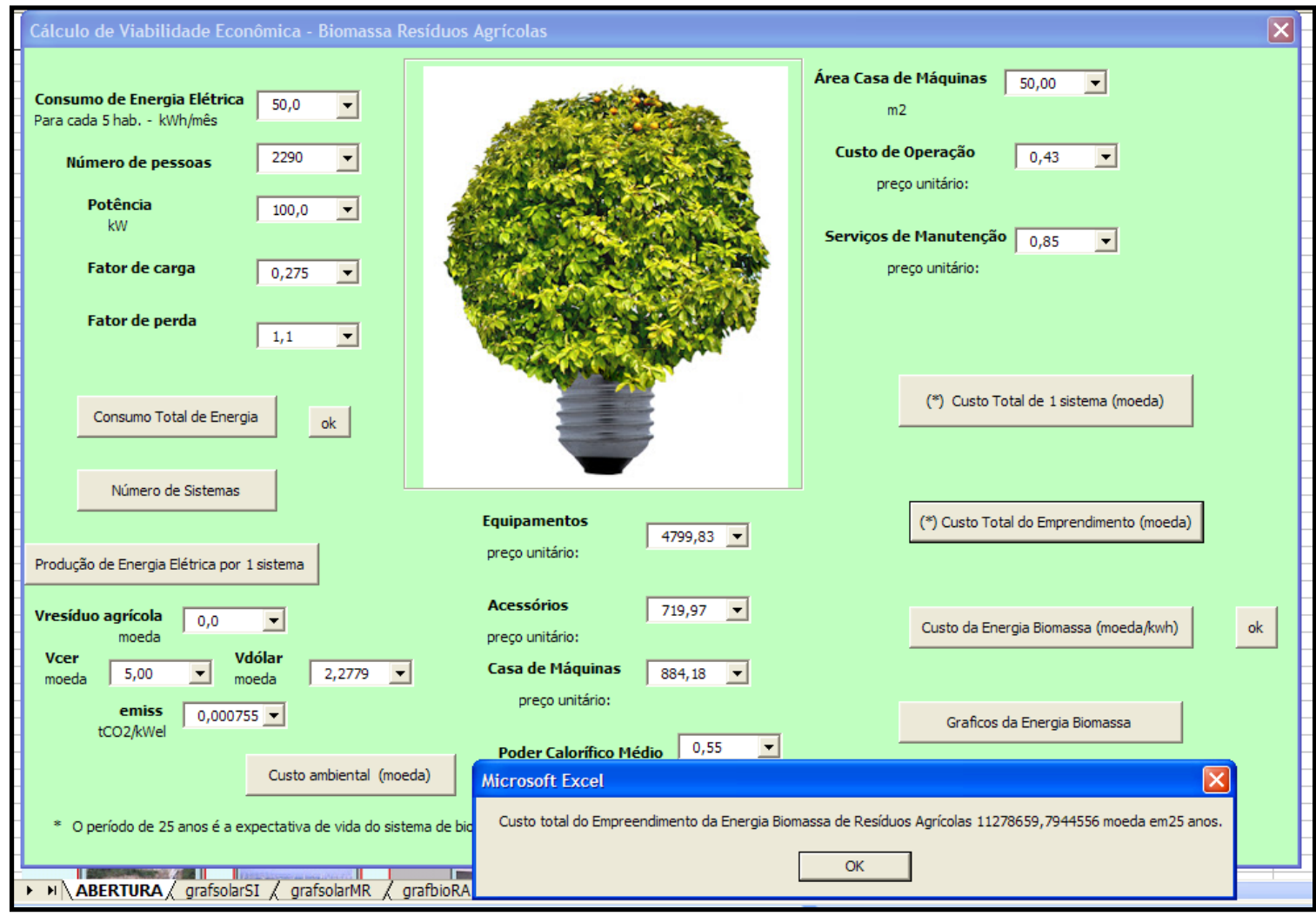

FIGURA 8.6 - Cálculo da Viabilidade Econômica para Biomassa - Resíduos Agrícolas

O PEASEB/v2 gerará uma pasta "tabela", com os principais resultados e uma pasta "grafbioRA", com os gráficos dos custos em função do número de habitantes da comunidade escolhida.

Se o usuário optar por utilizar a energia de biomassa de óleo de dendê, deverá clicar no botão "Óleo de Dendê", na tela de "ABERTURA", que tem um link para outra pasta de trabalho, denominada de "Cálculo de Viabilidade Econômica - Biomassa - Óleo de Dendê". Nesse caso, o usuário também deverá 
preencher as informações solicitadas na tela, conforme FIG. 8.7. Os dados utilizados são os fornecidos no capítulo 6 .

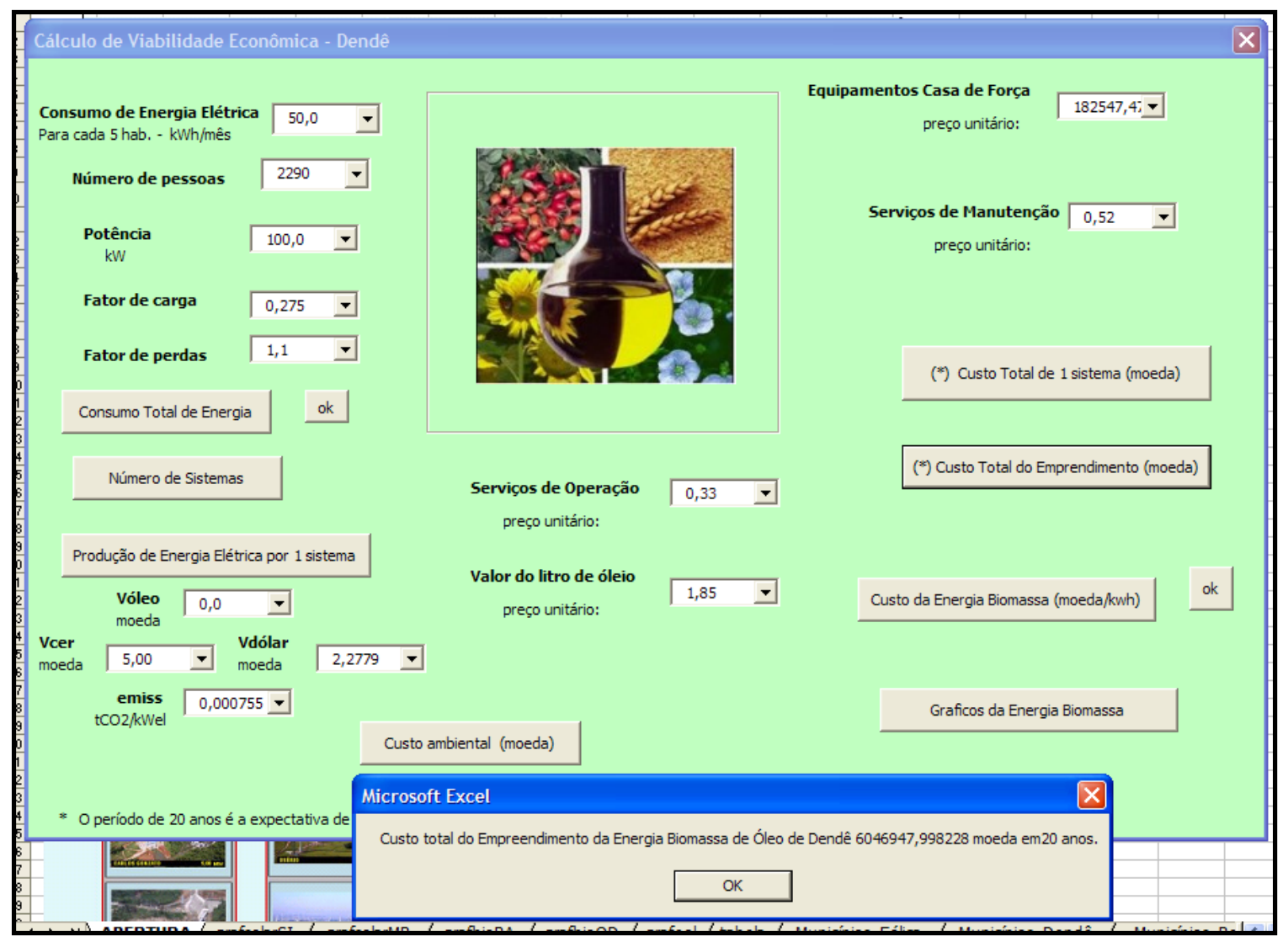

FIGURA 8.7 - Cálculo da Viabilidade Econômica para Biomassa - Óleo de Dendê

Como nos casos anteriores, o PEASEB/v2 gera a pasta "tabela", onde estão os principais resultados, e uma pasta "grafbioOD" , com os gráficos dos custos em função da população local do município.

\subsubsection{Energia Eólica no PEASEB/v2}

Se o usuário optar pela energia eólica, deve clicar no botão "Energia Eólica", que tem um link para outra pasta de trabalho, denominada de "Cálculo de Viabilidade Econômica - Energia Eólica", onde são inseridos os dados de entrada, conforme FIG. 8.8. 


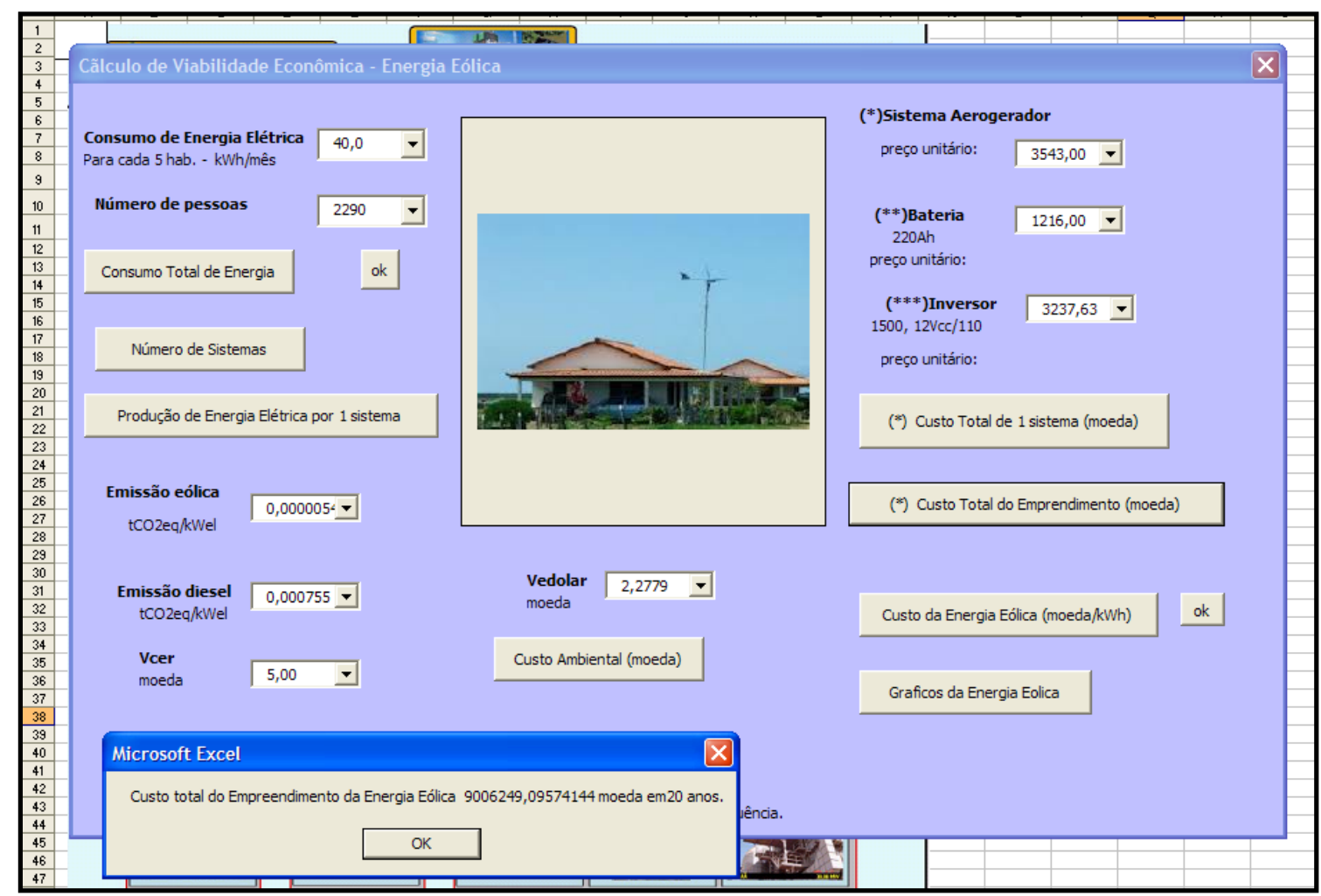

FIGURA 8.8 - Cálculo da Viabilidade Econômica para Energia Eólica

Além dos dados da instalação, o usuário também deverá fornecer os valores unitários na moeda desejada de cada um dos componentes do sistema eólico e os valores dos parâmetros para o cálculo dos custos evitados. Os dados utilizados são os fornecidos no capítulo 7.

A pasta "tabela" contém um resumo dos cálculos de viabilidade econômica da energia eólica, que também é gerado pelo PEASEB/v2, além do "grafeol" ,com os gráficos dos custos para uma determinada comunidade.

\subsection{Resumo do PEASEB/v2}

$\mathrm{Na}$ tela de "ABERTURA" do PEASEB/v2, há um botão "SOBRE o PEASEB/versão2". Ao clicá-lo, o usuário terá acesso a algumas informações importantes: como utilizar o programa e as modificações realizadas na versão original (FIG. 8.10). 


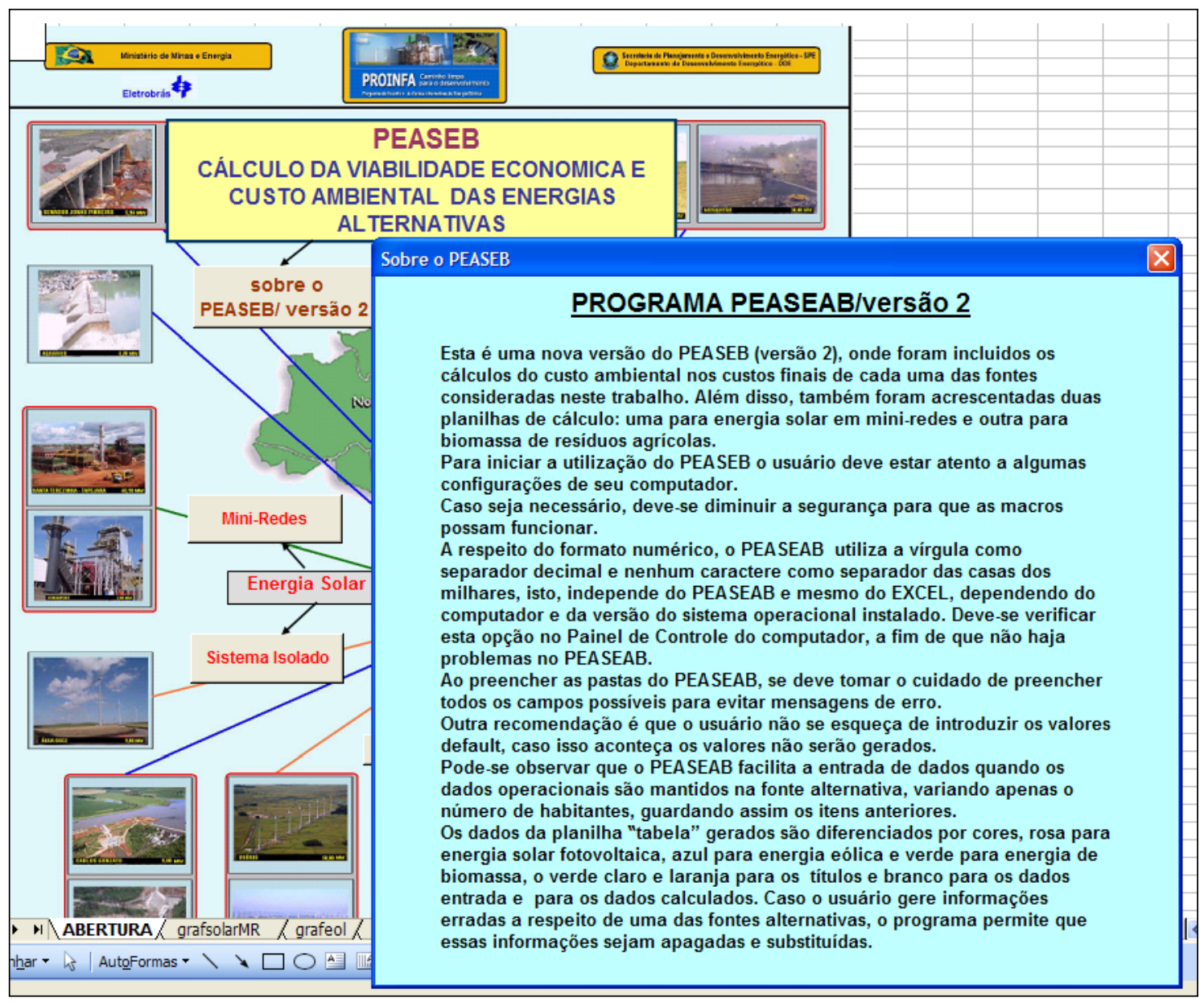

FIGURA 8.9 - Descrição do PEASEB/v2

O PEASEB/v2 foi testado com sucesso para todas as fontes de energia consideradas. 


\section{RESULTADOS E DISCUSSÕES}

A partir do equacionamento proposto para a análise da viabilidade econômica das três fontes de energia estudadas nesse trabalho, levando em consideração seus custos ambientais, demonstrados detalhadamente nos capítulos 5, 6 e 7, o programa PEASEB foi totalmente atualizado e reprogramado, gerando a nova versão, PEASEB/v2.

Definidas as equações, os cálculos foram feitos inicialmente, utilizando a planilha EXCEL. Nos cálculos realizados, foram consideradas as configurações dos sistemas para todas as fontes alternativas estudadas, definidas para todos os municípios com até 10.000 habitantes, para os nove estados que compõem a região nordeste brasileira.

Após os cálculos iniciais e a inserção das novas equações no PEASEB, que deu origem ao PEASEB/v2, demonstrado de forma detalhada no capítulo 8 , os cálculos foram refeitos, escolhendo-se aleatoriamente municípios de toda a região nordeste para a validação do programa. A nova versão do programa apresentou resultados idênticos aos obtidos na planilha EXCEL para os respectivos municípios e fontes de energia. Neste caso foram consideradas as fontes: solar (sistema isolado e minirredes), biomassa (resíduos agrícolas e óleo de dendê) e eólica.

O ANEXO B. apresenta as planilhas com a consolidação dos resultados obtidos a partir desses cálculos para todos os municípios da região nordeste. Os dados sintetizam os resultados obtidos dos custos ambientais e do custo dos empreendimentos, considerando a incorporação do custo evitado (externalidade positiva), calculado para todas as fontes alternativas de energia estudadas, obtendo-se, assim, os resultados das análises de viabilidade econômica dessas fontes.

Nas TAB 9.1 a 9.5 são mostrados os resultados completos para 3 municípios de cada estado, sendo um, o menor do estado em número de habitantes; outro intermediário em número de habitantes e o município mais populoso do estado, para as três fontes em todas as suas configurações. 
TABELA 9.1 - Amostragem dos resultados para energia solar fotovoltaica em minirredes

\begin{tabular}{|c|c|c|c|c|c|c|c|c|}
\hline Estado & Município & $\begin{array}{c}\quad N o \text { de } \\
\text { habitantes } \\
\text { projetados } \\
\text { (2012) }\end{array}$ & $\begin{array}{c}N^{\circ} \text { de } \\
\text { Famílias } \\
\text { (5 pessoas) }\end{array}$ & $\begin{array}{c}n^{\circ} \text { de } \\
\text { minirredes }\end{array}$ & $\begin{array}{c}\text { Energia } \\
\text { gerada em } \\
30 \text { anos } \\
\text { (kWh) }\end{array}$ & $\begin{array}{c}\text { Custo evitado } \\
\text { (R\$) }\end{array}$ & $\begin{array}{c}\text { Custo do } \\
\text { empreendimento } \\
(R \$)\end{array}$ & $\begin{array}{c}\text { Custo do } \\
\text { empreendimento } \\
\text { considerando a } \\
\text { externalidade } \\
\text { (R\$) }\end{array}$ \\
\hline $\mathrm{AL}$ & Pindoba & 2.857 & 571 & 143 & 14.966 .394 & $128.697,11$ & $22.708 .397,14$ & $22.579 .700,03$ \\
\hline $\mathrm{AL}$ & Palestina & 5.201 & 1040 & 260 & 27.211 .626 & $233.994,74$ & $41.287 .994,80$ & $41.054 .000,06$ \\
\hline $\mathrm{AL}$ & Maravilha & 9.981 & 1996 & 499 & 52.225 .390 & $449.089,91$ & $79.241 .190,02$ & $78.792 .100,11$ \\
\hline $\mathrm{BA}$ & Catolândia & 3.215 & 643 & 161 & 16.850 .276 & $144.896,75$ & $25.566 .796,78$ & $25.421 .900,03$ \\
\hline BA & Cravolândia & 5.048 & 1010 & 252 & 26.374 .345 & $226.794,91$ & $40.017 .594,96$ & $39.790 .800,05$ \\
\hline $\mathrm{BA}$ & Jucuruçu & 9.972 & 1994 & 499 & 52.225 .390 & $449.089,91$ & $79.241 .190,02$ & $78.792 .100,11$ \\
\hline $\mathrm{CE}$ & Guaramiranga & 3.956 & 791 & 198 & 20.722 .700 & $178.196,00$ & $31.442 .396,04$ & $31.264 .200,04$ \\
\hline $\mathrm{CE}$ & Pacujá & 6.037 & 1207 & 302 & 31.607 .350 & $271.793,90$ & $47.957 .593,96$ & $47.685 .800,06$ \\
\hline $\mathrm{CE}$ & $\begin{array}{c}\text { Deputado Irapuan } \\
\text { Pinheiro }\end{array}$ & 9.203 & 1841 & 460 & 48.143 .646 & $413.990,70$ & $73.047 .990,80$ & $72.634 .000,10$ \\
\hline MA & Junco do Maranhão & 3.792 & 758 & 190 & 19.885 .419 & $170.996,16$ & $30.171 .996,20$ & $30.001 .000,04$ \\
\hline MA & Nova Colinas & 5.034 & 1007 & 252 & 26.374 .345 & $226.794,91$ & $40.017 .594,96$ & $39.790 .800,05$ \\
\hline MA & Fernando Falcão & 9.584 & 1917 & 479 & 50.132 .188 & $431.090,32$ & $76.065 .190,42$ & $75.634 .100,10$ \\
\hline PB & $\begin{array}{l}\text { São José do Brejo do } \\
\text { Cruz }\end{array}$ & 1.707 & 341 & 85 & 8.896.109 & $76.498,28$ & $13.497 .998,30$ & $13.421 .500,02$ \\
\hline PB & Vieirópolis & 5.102 & 1020 & 255 & 26.688 .326 & $229.494,85$ & $40.493 .994,90$ & $40.264 .500,05$ \\
\hline $\mathrm{PB}$ & Juru & 9.793 & 1959 & 490 & 51.283 .449 & $440.990,10$ & $77.811 .990,20$ & $77.371 .000,10$ \\
\hline $\mathrm{PE}$ & Fernando de Noronha & 2.718 & 544 & 136 & 14.233 .774 & $122.397,25$ & $21.596 .797,28$ & $21.474 .400,03$ \\
\hline $\mathrm{PE}$ & Calumbi & 5.643 & 1129 & 282 & 29.514 .148 & $253.794,30$ & $44.781 .594,36$ & $44.527 .800,06$ \\
\hline $\mathrm{PE}$ & Salgadinho & 9.641 & 1928 & 482 & 50.446 .168 & $433.790,26$ & $76.541 .590,36$ & $76.107 .800,10$ \\
\hline $\mathrm{PI}$ & Miguel Leão & 1.236 & 247 & 62 & 6.488 .926 & $55.798,75$ & $9.845 .598,76$ & $9.789 .800,01$ \\
\hline $\mathrm{PI}$ & Agricolândia & 5.062 & 1012 & 253 & 26.479 .005 & $227.694,89$ & $40.176 .394,94$ & $39.948 .700,05$ \\
\hline $\mathrm{PI}$ & Beneditinos & 9.943 & 1989 & 497 & 52.016 .070 & $447.289,95$ & $78.923 .590,06$ & $78.476 .300,11$ \\
\hline $\mathrm{RN}$ & Viçosa & 1.633 & 327 & 82 & 8.582 .128 & $73.798,34$ & $13.021 .598,36$ & $12.947 .800,02$ \\
\hline $\mathrm{RN}$ & Sítio Novo & 5.107 & 1021 & 255 & 26.688 .326 & $229.494,85$ & $40.493 .994,90$ & $40.264 .500,05$ \\
\hline $\mathrm{RN}$ & Luís Gomes & 9.679 & 1936 & 484 & 50.655 .488 & $435.590,22$ & $76.859 .190,32$ & $76.423 .600,10$ \\
\hline SE & $\begin{array}{l}\text { Amparo de São } \\
\text { Francisco }\end{array}$ & 2.290 & 458 & 115 & 12.035 .912 & $103.497,68$ & $18.261 .997,70$ & $18.158 .500,02$ \\
\hline SE & Feira Nova & 5.363 & 1073 & 268 & 28.048 .907 & $241.194,58$ & $42.558 .394,64$ & $42.317 .200,06$ \\
\hline SE & Rosário do Catete & 9.541 & 1908 & 477 & 49.922 .868 & $429.290,36$ & $75.747 .590,46$ & $75.318 .300,10$ \\
\hline
\end{tabular}


TABELA 9.2 - Amostragem dos resultados para energia solar fotovoltaica em sistemas isolados

\begin{tabular}{|c|c|c|c|c|c|c|c|c|}
\hline Estado & Município & $\begin{array}{c}\quad N^{o} \text { de } \\
\text { habitantes } \\
\text { projetados } \\
\text { (2012) }\end{array}$ & $\begin{array}{c}N^{\circ} \text { de } \\
\text { Famílias } \\
\text { (5 pessoas) }\end{array}$ & $\begin{array}{c}\text { no de } \\
\text { sistemas } \\
\text { isolados }\end{array}$ & $\begin{array}{c}\text { Energia } \\
\text { gerada em } \\
30 \text { anos } \\
\text { (kWh) }\end{array}$ & $\begin{array}{c}\text { Custo evitado } \\
\text { (R\$) }\end{array}$ & $\begin{array}{c}\text { Custo do } \\
\text { empreendimento } \\
(R \$)\end{array}$ & $\begin{array}{c}\text { Custo do } \\
\text { empreendimento } \\
\text { considerando a } \\
\text { externalidade }(\boldsymbol{R} \$)\end{array}$ \\
\hline $\mathrm{AL}$ & Pindoba & 2.857 & 571 & 571 & 31.008 .849 & $266.647,34$ & $41.354 .503,60$ & $41.087 .856,26$ \\
\hline $\mathrm{AL}$ & Palestina & 5.201 & 1040 & 1040 & 56.449 .782 & $485.415,76$ & $75.283 .434,80$ & 74.798.019,04 \\
\hline $\mathrm{AL}$ & Maravilha & 9.981 & 1996 & 1996 & 108.330 .181 & $931.539,08$ & $144.472 .978,80$ & $143.541 .439,72$ \\
\hline $\mathrm{BA}$ & Catolândia & 3.215 & 643 & 643 & 34.894 .453 & $300.059,93$ & $46.536 .482,00$ & $46.236 .422,07$ \\
\hline BA & Cravolândia & 5.048 & 1010 & 1010 & 54.789 .175 & $471.136,09$ & $73.068 .790,40$ & $72.597 .654,31$ \\
\hline $\mathrm{BA}$ & Jucuruçu & 9.972 & 1994 & 1994 & 108.232 .498 & $930.699,10$ & $144.342 .705,60$ & $143.412 .006,50$ \\
\hline $\mathrm{CE}$ & Guaramiranga & 3.956 & 791 & 791 & 42.937 .000 & $369.218,37$ & $57.262 .308,80$ & $56.893 .090,43$ \\
\hline $\mathrm{CE}$ & Pacujá & 6.037 & 1207 & 1207 & 65.523 .425 & $563.440,68$ & $87.384 .367,60$ & $86.820 .926,92$ \\
\hline CE & $\begin{array}{c}\text { Deputado Irapuan } \\
\text { Pinheiro }\end{array}$ & 9.203 & 1841 & 1841 & 99.886 .049 & 858.927,38 & $133.211 .584,40$ & $132.352 .657,02$ \\
\hline $\mathrm{MA}$ & Junco do Maranhão & 3.792 & 758 & 758 & 41.157 .003 & $353.912,05$ & $54.888 .441,60$ & $54.534 .529,55$ \\
\hline MA & Nova Colinas & 5.034 & 1007 & 1007 & 54.637 .224 & $469.829,45$ & $72.866 .143,20$ & $72.396 .313,75$ \\
\hline $\mathrm{MA}$ & Fernando Falcão & 9.584 & 1917 & 1917 & 104.021 .286 & $894.486,58$ & $138.726 .483,20$ & $137.831 .996,62$ \\
\hline PB & $\begin{array}{l}\text { São José do Brejo do } \\
\text { Cruz }\end{array}$ & 1.707 & 341 & 341 & 18.527 .163 & $159.316,42$ & $24.708 .483,60$ & $24.549 .167,18$ \\
\hline PB & Vieirópolis & 5.102 & 1020 & 1020 & 55.375 .271 & $476.175,97$ & $73.850 .429,60$ & $73.374 .253,63$ \\
\hline PB & Juru & 9.793 & 1959 & 1959 & 106.289 .697 & $913.992,81$ & $141.751 .716,40$ & $140.837 .723,59$ \\
\hline $\mathrm{PE}$ & Fernando de Noronha & 2.718 & 544 & 544 & 29.500 .194 & $253.674,30$ & $39.342 .506,40$ & $39.088 .832,10$ \\
\hline $\mathrm{PE}$ & Calumbi & 5.643 & 1129 & 1129 & 61.247 .091 & $526.668,17$ & $81.681 .296,40$ & $81.154 .628,23$ \\
\hline $\mathrm{PE}$ & Salgadinho & 9.641 & 1928 & 1928 & 104.639 .943 & $899.806,46$ & $139.551 .546,80$ & $138.651 .740,34$ \\
\hline $\mathrm{PI}$ & Miguel Leão & 1.236 & 247 & 247 & 13.415 .099 & $115.357,41$ & $17.890 .852,80$ & $17.775 .495,39$ \\
\hline $\mathrm{PI}$ & Agricolândia & 5.062 & 1012 & 1012 & 54.941 .126 & $472.442,72$ & $73.271 .437,60$ & $72.798 .994,88$ \\
\hline $\mathrm{PI}$ & Beneditinos & 9.943 & 1989 & 1989 & 107.917 .743 & $927.992,49$ & $143.922 .936,40$ & $142.994 .943,91$ \\
\hline $\mathrm{RN}$ & Viçosa & 1.633 & 327 & 327 & 17.723 .994 & $152.409,91$ & $23.637 .348,40$ & $23.484 .938,49$ \\
\hline $\mathrm{RN}$ & Sítio Novo & 5.107 & 1021 & 1021 & 55.429 .539 & $476.642,63$ & $73.922 .803,60$ & $73.446 .160,97$ \\
\hline $\mathrm{RN}$ & Luís Gomes & 9.679 & 1936 & 1936 & 105.052 .382 & $903.353,05$ & $140.101 .589,20$ & $139.198 .236,15$ \\
\hline SE & $\begin{array}{l}\text { Amparo de São } \\
\text { Francisco }\end{array}$ & 2.290 & 458 & 458 & 24.854 .836 & $213.728,53$ & $33.147 .292,00$ & $32.933 .563,47$ \\
\hline SE & Feira Nova & 5.363 & 1073 & 1073 & 58.208 .071 & $500.535,43$ & $77.628 .352,40$ & $77.127 .816,97$ \\
\hline SE & Rosário do Catete & 9.541 & 1908 & 1908 & 103.554 .579 & $890.473,33$ & $138.104 .066,80$ & $137.213 .593,47$ \\
\hline
\end{tabular}


TABELA 9.3 - Amostragem dos resultados para biomassa de resíduos agrícolas

\begin{tabular}{|c|c|c|c|c|c|c|c|c|c|c|c|}
\hline Estado & Município & $\begin{array}{c}\quad № \text { de } \\
\text { habitantes } \\
\text { projetados } \\
\text { (2012) }\end{array}$ & $\begin{array}{c}N^{\circ} \text { de } \\
\text { Famílias } \\
(5 \\
\text { pessoas) }\end{array}$ & $\begin{array}{c}n^{o} \text { de } \\
\text { minirredes }\end{array}$ & $\begin{array}{c}\text { Energia } \\
\text { gerada em } \\
25 \text { anos } \\
\text { (kWh) }\end{array}$ & $\begin{array}{c}\text { Custo Inicial } \\
\text { estimado(Cl) } \\
\text { (R\$) }\end{array}$ & $\begin{array}{c}\text { Custo } \\
\text { estimado de } \\
\text { manutenção } \\
(C M)(R \$)\end{array}$ & $\begin{array}{c}\text { Custo } \\
\text { estimado de } \\
\text { operação } \\
\text { (CO) }(R \$)\end{array}$ & $\begin{array}{l}\text { Custo do } \\
\text { empreendimento } \\
\text { (R\$) }\end{array}$ & $\begin{array}{c}\text { Custo } \\
\text { evitado } \\
\text { (R\$) }\end{array}$ & $\begin{array}{c}\text { Custo do } \\
\text { empreendimento } \\
\text { considerando a } \\
\text { externalidade } \\
\text { (R\$) }\end{array}$ \\
\hline$\overline{A L}$ & Pindoba & 2.857 & 571 & 1 & 6.624 .750 & $596.189,00$ & $5.631 .037,50$ & $5.108 .400,00$ & $11.335 .626,50$ & $56.966,71$ & $\frac{11.278 .659,79}{1}$ \\
\hline$\overline{\mathrm{AL}}$ & Palestina & 5.201 & 1040 & 2 & 13.249 .500 & $1.192 .378,00$ & $11.262 .075,00$ & $10.216 .800,00$ & $22.671 .253,00$ & $113.933,41$ & $22.557 .319,59$ \\
\hline$A L$ & Maravilha & 9.981 & 1996 & 5 & 33.123 .750 & $2.980 .945,00$ & $28.155 .187,50$ & $25.542 .000,00$ & $56.678 .132,50$ & $284.833,53$ & $56.393 .298,97$ \\
\hline BA & Catolândia & 3.215 & 643 & 1 & 6.624 .750 & $596.189,00$ & $5.631 .037,50$ & $5.108 .400,00$ & $11.335 .626,50$ & $56.966,71$ & $11.278 .659,79$ \\
\hline BA & Cravolândia & 5.048 & 1010 & 2 & 13.249 .500 & $1.192 .378,00$ & $11.262 .075,00$ & $10.216 .800,00$ & $22.671 .253,00$ & $113.933,41$ & $22.557 .319,59$ \\
\hline $\mathrm{BA}$ & Jucuruçu & 9.972 & 1994 & 5 & 33.123 .750 & $2.980 .945,00$ & $28.155 .187,50$ & $25.542 .000,00$ & $56.678 .132,50$ & $284.833,53$ & $56.393 .298,97$ \\
\hline $\mathrm{CE}$ & Guaramiranga & 3.956 & 791 & 2 & 13.249 .500 & $1.192 .378,00$ & $11.262 .075,00$ & $10.216 .800,00$ & $22.671 .253,00$ & $113.933,41$ & $22.557 .319,59$ \\
\hline $\mathrm{CE}$ & Pacujá & 6.037 & 1207 & 3 & 19.874 .250 & $1.788 .567,00$ & $16.893 .112,50$ & $15.325 .200,00$ & $34.006 .879,50$ & $170.900,12$ & $33.835 .979,38$ \\
\hline CE & $\begin{array}{l}\text { Deputado } \\
\text { Irapuan } \\
\text { Pinheiro }\end{array}$ & 9.203 & 1841 & 4 & 26.499 .000 & $2.384 .756,00$ & $22.524 .150,00$ & $20.433 .600,00$ & $45.342 .506,00$ & $227.866,82$ & $45.114 .639,18$ \\
\hline MA & $\begin{array}{l}\text { Junco do } \\
\text { Maranhão }\end{array}$ & 3.792 & 758 & 2 & 13.249 .500 & $1.192 .378,00$ & $11.262 .075,00$ & $10.216 .800,00$ & $22.671 .253,00$ & $113.933,41$ & $22.557 .319,59$ \\
\hline $\mathrm{MA}$ & Nova Colinas & 5.034 & 1007 & 2 & 13.249 .500 & $1.192 .378,00$ & $11.262 .075,00$ & $10.216 .800,00$ & $22.671 .253,00$ & $113.933,41$ & $22.557 .319,59$ \\
\hline MA & $\begin{array}{c}\text { Fernando } \\
\text { Falcão }\end{array}$ & 9.584 & 1917 & 4 & 26.499 .000 & $2.384 .756,00$ & $22.524 .150,00$ & $20.433 .600,00$ & $45.342 .506,00$ & $227.866,82$ & $45.114 .639,18$ \\
\hline PB & $\begin{array}{l}\text { São José do } \\
\text { Brejo do Cruz }\end{array}$ & 1.707 & 341 & 1 & 6.624 .750 & $596.189,00$ & $5.631 .037,50$ & $5.108 .400,00$ & $11.335 .626,50$ & $56.966,71$ & $11.278 .659,79$ \\
\hline $\mathrm{PB}$ & Vieirópolis & 5.102 & 1020 & 2 & 13.249 .500 & $1.192 .378,00$ & 11.262 & $10.216 .800,00$ & $22.671 .253,00$ & 113.9 & $22.557 .319,59$ \\
\hline PB & Juru & 9.793 & 1959 & 5 & 33.123 .750 & $2.980 .945,00$ & $28.155 .187,50$ & $25.542 .000,00$ & $56.678 .132,50$ & $284.833,53$ & $56.393 .298,97$ \\
\hline PE & $\begin{array}{l}\text { Fernando de } \\
\text { Noronha }\end{array}$ & 2.718 & 544 & 1 & 6.624 .750 & $596.189,00$ & $5.631 .037,50$ & $5.108 .400,00$ & $11.335 .626,50$ & $56.966,71$ & $11.278 .659,79$ \\
\hline $\mathrm{PE}$ & Calumbi & 5.643 & 1129 & 3 & 19.874 .250 & $1.788 .567,00$ & $16.893 .112,50$ & $15.325 .200,00$ & $34.006 .879,50$ & $170.900,12$ & $33.835 .979,38$ \\
\hline $\mathrm{PE}$ & Salgadinho & 9.641 & 1928 & 4 & 26.499 .000 & $2.384 .756,00$ & $22.524 .150,00$ & $20.433 .600,00$ & $45.342 .506,00$ & $227.866,82$ & $45.114 .639,18$ \\
\hline $\mathrm{PI}$ & Miguel Leão & 1.236 & 247 & 1 & 6.624 .750 & $596.189,00$ & $5.631 .037,50$ & $5.108 .400,00$ & $11.335 .626,50$ & $56.966,71$ & $11.278 .659,79$ \\
\hline $\mathrm{PI}$ & Agricolândia & 5.062 & 1012 & $\bar{s}$ & 13.249 .500 & $1.192 .378,00$ & $11.262 .075,00$ & $10.216 .800,00$ & $22.671 .253,00$ & $113.933,41$ & $22.557 .319,59$ \\
\hline $\mathrm{PI}$ & Beneditinos & 9.943 & 1989 & 5 & 33.123 .750 & $2.980 .945,00$ & $28.155 .187,50$ & $25.542 .000,00$ & $56.678 .132,50$ & $284.833,53$ & $56.393 .298,97$ \\
\hline $\mathrm{RN}$ & Viçosa & 1.633 & 327 & 1 & 6.624 .750 & $596.189,00$ & $5.631 .037,50$ & $5.108 .400,00$ & $11.335 .626,50$ & $56.966,71$ & $11.278 .659,79$ \\
\hline RN & Sítio Novo & 5.107 & 1021 & 2 & 13.249 .500 & $1.192 .378,00$ & $11.262 .075,00$ & $10.216 .800,00$ & $22.671 .253,00$ & $113.933,41$ & $22.557 .319,59$ \\
\hline $\mathrm{RN}$ & Luís Gomes & 9.679 & 1936 & 4 & 26.499 .000 & $2.384 .756,00$ & $22.524 .150,00$ & $20.433 .600,00$ & $45.342 .506,00$ & $227.866,82$ & $45.114 .639,18$ \\
\hline SE & $\begin{array}{c}\text { Amparo de } \\
\text { São Francisco }\end{array}$ & 2.290 & 458 & 1 & 6.624 .750 & $596.189,00$ & $1.037,50$ & $5.108 .400,00$ & $11.335 .626,50$ & $56.966,71$ & $278.659,79$ \\
\hline SE & Feira Nova & 5.363 & 1073 & 2 & 13.249 .500 & $1.192 .378,00$ & $11.262 .075,00$ & $10.216 .800,00$ & $22.671 .253,00$ & $113.933,41$ & $22.557 .319,59$ \\
\hline SE & $\begin{array}{l}\text { Rosário do } \\
\text { Catete }\end{array}$ & 9.541 & 1908 & 4 & 26.499 .000 & $2.384 .756,00$ & $22.524 .150,00$ & $20.433 .600,00$ & $45.342 .506,00$ & $227.866,82$ & $45.114 .639,18$ \\
\hline
\end{tabular}


TABELA 9.4 - Amostragem dos resultados para biomassa de óleo de dendê

\begin{tabular}{|c|c|c|c|c|c|c|c|c|c|c|c|}
\hline Estado & Município & $\begin{array}{c}\text { № de } \\
\text { habitantes } \\
\text { projetados } \\
\text { (2012) }\end{array}$ & $\begin{array}{c}N^{\circ} d e \\
\text { Famílias } \\
(5 \\
\text { pessoas) }\end{array}$ & $\begin{array}{c}n o \text { de } \\
\text { minirredes }\end{array}$ & $\begin{array}{c}\text { Energia } \\
\text { gerada em } \\
20 \text { anos } \\
\text { (kWh) }\end{array}$ & $\begin{array}{c}\text { Custo Inicial } \\
\text { estimado(Cl) } \\
\text { (R\$) }\end{array}$ & $\begin{array}{c}\text { Custo } \\
\text { estimado de } \\
\text { manutenção } \\
(C M)(R \$)\end{array}$ & $\begin{array}{c}\text { Custo } \\
\text { estimado de } \\
\text { operação } \\
\text { (CO) }(R \$)\end{array}$ & $\begin{array}{c}\text { Custo do } \\
\text { empreendimento } \\
\text { (R\$) }\end{array}$ & $\begin{array}{l}\text { Custo } \\
\text { evitado } \\
\text { (R\$) }\end{array}$ & $\begin{array}{c}\text { Custo do } \\
\text { empreendimento } \\
\text { considerando a } \\
\text { externalidade } \\
\text { (R\$) }\end{array}$ \\
\hline$\overline{\mathrm{AL}}$ & Pindoba & 2.857 & 571 & 1 & 5.227 .200 & $182.547,47$ & $2.718 .144,00$ & $3.191 .205,60$ & $6.091 .897,07$ & $44.949,07$ & $6.046 .948,00$ \\
\hline$\overline{\mathrm{AL}}$ & Palestina & 5.201 & 1040 & 2 & 10.454 .400 & $365.094,94$ & $5.436 .288,00$ & $6.382 .411,20$ & $12.183 .794,14$ & $89.898,14$ & $12.093 .896,00$ \\
\hline $\mathrm{AL}$ & Maravilha & 9.981 & 1996 & 5 & 26.136 .000 & $912.737,35$ & $13.590 .720,00$ & $15.956 .028,00$ & $30.459 .485,35$ & $224.745,36$ & $30.234 .739,99$ \\
\hline $\mathrm{BA}$ & Catolândia & 3.215 & 643 & 1 & 5.227 .200 & $182.547,47$ & $2.718 .144,00$ & $3.191 .205,60$ & $6.091 .897,07$ & $44.949,07$ & $6.046 .948,00$ \\
\hline $\mathrm{BA}$ & Cravolândia & 5.048 & 1010 & 2 & 10.454 .400 & $365.094,94$ & $5.436 .288,00$ & $6.382 .411,20$ & $12.183 .794,14$ & $89.898,14$ & $12.093 .896,00$ \\
\hline $\mathrm{BA}$ & Jucuruçu & 9.972 & 1994 & 5 & 26.136 .000 & $912.737,35$ & $13.590 .720,00$ & $15.956 .028,00$ & $30.459 .485,35$ & $224.745,36$ & $30.234 .739,99$ \\
\hline $\mathrm{CE}$ & Guaramiranga & 3.956 & 791 & 2 & 10.454 .400 & $365.094,94$ & $5.436 .288,00$ & $6.382 .411,20$ & $12.183 .794,14$ & $89.898,14$ & $12.093 .896,00$ \\
\hline $\mathrm{CE}$ & Pacujá & 6.037 & 1207 & 3 & 15.681 .600 & $547.642,41$ & $8.154 .432,00$ & $9.573 .616,80$ & $18.275 .691,21$ & $134.847,22$ & $18.140 .843,99$ \\
\hline CE & $\begin{array}{l}\text { Deputado } \\
\text { Irapuan } \\
\text { Pinheiro } \\
\end{array}$ & 9.203 & 1841 & 4 & 20.908 .800 & $730.189,88$ & $10.872 .576,00$ & $12.764 .822,40$ & $24.367 .588,28$ & $179.796,29$ & 24.187.791,99 \\
\hline MA & $\begin{array}{l}\text { Junco do } \\
\text { Maranhão }\end{array}$ & 3.792 & 758 & 2 & 10.454 .400 & $365.094,94$ & $5.436 .288,00$ & $6.382 .411,20$ & $12.183 .794,14$ & $89.898,14$ & $12.093 .896,00$ \\
\hline MA & Nova Colinas & 5.034 & 1007 & 2 & 10.454 .400 & $365.094,94$ & $5.436 .288,00$ & $6.382 .411,20$ & $12.183 .794,14$ & $89.898,14$ & $12.093 .896,00$ \\
\hline MA & $\begin{array}{c}\text { Fernando } \\
\text { Falcão }\end{array}$ & 9.584 & 1917 & 4 & 20.908 .800 & $730.189,88$ & $10.872 .576,00$ & $12.764 .822,40$ & $24.367 .588,28$ & $179.796,29$ & $24.187 .791,99$ \\
\hline PB & $\begin{array}{l}\text { São José do } \\
\text { Brejo do Cruz }\end{array}$ & 1.707 & 341 & 1 & 5.227 .200 & $182.547,47$ & $2.718 .144,00$ & $3.191 .205,60$ & $6.091 .897,07$ & $44.949,07$ & $6.046 .948,00$ \\
\hline $\mathrm{PB}$ & Vieirópolis & 5.102 & 1020 & 2 & 10.454 .400 & $365.094,94$ & $5.436 .288,00$ & 6.382 & $12.183 .794,14$ & $89.898,14$ & $12.093 .896,00$ \\
\hline PB & Juru & 9.793 & 1959 & 5 & 26.136 .000 & $912.737,35$ & $13.590 .720,00$ & $15.956 .028,00$ & $30.459 .485,35$ & $224.745,36$ & $30.234 .739,99$ \\
\hline PE & $\begin{array}{l}\text { Fernando de } \\
\text { Noronha }\end{array}$ & 2.718 & 544 & 1 & 5.227 .200 & $182.547,47$ & $2.718 .144,00$ & $3.191 .205,60$ & $6.091 .897,07$ & $44.949,07$ & $6.046 .948,00$ \\
\hline $\mathrm{PE}$ & Calumbi & 643 & 1129 & 3 & .600 & 2,41 & 8.154. & 9.573 & $18.275 .691,21$ & $134.847,22$ & $18.140 .843,99$ \\
\hline $\mathrm{PE}$ & Salgadinho & 641 & 1928 & 4 & 20.908 .800 & $730.189,88$ & $10.872 .576,00$ & $12.764 .822,40$ & $24.367 .588,28$ & $179.796,29$ & $24.187 .791,99$ \\
\hline $\mathrm{PI}$ & Miguel Leão & 1.236 & 247 & 1 & 5.227 .200 & $182.547,47$ & $2.718 .144,00$ & $3.191 .205,60$ & $6.091 .897,07$ & $44.949,07$ & $6.046 .948,00$ \\
\hline $\mathrm{PI}$ & Agricolândia & 5.062 & 1012 & 2 & 10.454 .400 & $365.094,94$ & $5.436 .288,00$ & $6.382 .411,20$ & $12.183 .794,14$ & $89.898,14$ & $12.093 .896,00$ \\
\hline $\mathrm{PI}$ & Beneditinos & 9.943 & 1989 & 5 & 26.136 .000 & 37,35 & $13.590 .720,00$ & $15.956 .028,00$ & $30.459 .485,35$ & $224.745,36$ & $30.234 .739,99$ \\
\hline $\mathrm{RN}$ & Viçosa & 633 & 327 & 1 & 5.227 .200 & 7,47 & 2.718 & 3.191 & 897,07 & $44.949,07$ & $6.046 .948,00$ \\
\hline $\mathrm{RN}$ & Sítio Novo & 5.107 & 1021 & 2 & 10.454 .400 & $365.094,94$ & $5.436 .288,00$ & $6.382 .411,20$ & $12.183 .794,14$ & $89.898,14$ & $12.093 .896,00$ \\
\hline $\mathrm{RN}$ & Luís Gomes & 9.679 & 1936 & 4 & 20.908 .800 & $730.189,88$ & $10.872 .576,00$ & $12.764 .822,40$ & $24.367 .588,28$ & $179.796,29$ & $24.187 .791,99$ \\
\hline SE & $\begin{array}{c}\text { Amparo de } \\
\text { São Francisco }\end{array}$ & 2.290 & 458 & 1 & 5.227 .200 & $182.547,47$ & $2.718 .144,00$ & $3.191 .205,60$ & $6.091 .897,07$ & $44.949,07$ & $6.046 .948,00$ \\
\hline SE & Feira Nova & 5.363 & 1073 & 2 & 10.454 .400 & $365.094,94$ & $5.436 .288,00$ & $6.382 .411,20$ & $12.183 .794,14$ & $89.898,14$ & $12.093 .896,00$ \\
\hline SE & $\begin{array}{l}\text { Rosário do } \\
\text { Catete }\end{array}$ & 9.541 & 1908 & 4 & 20.908 .800 & $730.189,88$ & $10.872 .576,00$ & $12.764 .822,40$ & $24.367 .588,28$ & $179.796,29$ & $24.187 .791,99$ \\
\hline
\end{tabular}


TABELA 9.5 - Amostragem dos resultados para energia eólica

\begin{tabular}{|c|c|c|c|c|c|c|c|c|c|c|}
\hline Estado & Município & $\begin{array}{c}\text { № de } \\
\text { habitantes } \\
\text { projetados } \\
\text { (2012) }\end{array}$ & $\begin{array}{l}N^{\circ} d e \\
\text { Famílias } \\
\quad(5 \\
\text { pessoas })\end{array}$ & $\begin{array}{c}n^{\circ} \text { de } \\
\text { sistemas }\end{array}$ & $\begin{array}{l}\text { Energia } \\
\text { Gerada } \\
\text { em } 20 \\
\text { anos } \\
\text { (kWh) }\end{array}$ & $\begin{array}{c}\text { Custo do } \\
\text { empreendimento } \\
\text { (R\$) }\end{array}$ & $\begin{array}{l}\text { VERA } \\
\text { Diesel }\end{array}$ & $\begin{array}{l}\text { VERA } \\
\text { Eólica }\end{array}$ & $\begin{array}{c}\text { Custo } \\
\text { evitado }(R \$)\end{array}$ & $\begin{array}{c}\text { Custo do } \\
\text { empreendimento } \\
\text { considerando a } \\
\text { externalidade (R\$) }\end{array}$ \\
\hline$\overline{A L}$ & Pindoba & 2.857 & 571 & 571 & 5.485 .440 & $11.283 .584,36$ & $47.169,70$ & 337,37 & $46.832,32$ & $11.236 .752,04$ \\
\hline $\mathrm{AL}$ & Palestina & 5.201 & 1040 & 1040 & 9.985 .920 & $20.541 .099,85$ & $85.869,65$ & 614,17 & $85.255,48$ & $20.455 .844,37$ \\
\hline $\mathrm{AL}$ & Maravilha & 9.981 & 1996 & 1996 & 19.163 .520 & $39.419 .480,41$ & $164.788,50$ & $1.178,62$ & $163.609,88$ & $39.255 .870,53$ \\
\hline BA & Catolândia & 3.215 & 643 & 643 & 6.172 .800 & $12.696 .845,18$ & $53.080,35$ & 379,65 & $52.700,71$ & $12.644 .144,47$ \\
\hline BA & Cravolândia & 5.048 & 1010 & 1010 & 9.692 .160 & $19.935 .824,10$ & $83.343,59$ & 596,10 & $82.747,49$ & $19.853 .076,61$ \\
\hline BA & Jucuruçu & 9.972 & 1994 & 1994 & 19.146 .240 & $39.381 .940,94$ & $164.639,91$ & $1.177,56$ & $163.462,35$ & $39.218 .478,60$ \\
\hline $\mathrm{CE}$ & Guaramiranga & 3.956 & 791 & 791 & 7.595 .520 & $15.623 .240,91$ & $65.314,43$ & 467,15 & $64.847,28$ & $15.558 .393,63$ \\
\hline $\mathrm{CE}$ & Pacujá & 6.037 & 1207 & 1207 & 11.591 .040 & $23.841 .634,32$ & $99.672,19$ & 712,89 & $98.959,31$ & $23.742 .675,02$ \\
\hline CE & $\begin{array}{c}\text { Deputado } \\
\text { Irapuan Pinheiro }\end{array}$ & 9.203 & 1841 & 1841 & 17.669 .760 & $36.344 .966,16$ & $151.943,55$ & $1.086,75$ & $150.856,80$ & $36.194 .109,36$ \\
\hline MA & $\begin{array}{l}\text { Junco do } \\
\text { Maranhão }\end{array}$ & 3.792 & 758 & 758 & 7.280 .640 & $14.975 .563,58$ & $62.606,75$ & 447,78 & $62.158,97$ & $14.913 .404,62$ \\
\hline $\mathrm{MA}$ & Nova Colinas & 5.034 & 1007 & 1007 & 9.665 .280 & $19.880 .534,57$ & $83.112,44$ & 594,45 & $82.518,00$ & $19.798 .016,57$ \\
\hline MA & $\begin{array}{l}\text { Fernando } \\
\text { Falcão }\end{array}$ & 9.584 & 1917 & 1917 & 18.401 .280 & $37.849 .631,17$ & $158.233,94$ & $1.131,74$ & $157.102,20$ & $37.692 .528,97$ \\
\hline PB & $\begin{array}{l}\text { São José do } \\
\text { Brejo do Cruz }\end{array}$ & 1.707 & 341 & 341 & 3.277 .440 & $6.741 .373,16$ & $28.182,94$ & 201,57 & $27.981,37$ & $6.713 .391,79$ \\
\hline PB & Vieirópolis & 5.102 & 1020 & 1020 & 9.795 .840 & $20.149 .083,70$ & $84.235,14$ & 602,48 & $83.632,66$ & $20.065 .451,04$ \\
\hline PB & Juru & 9.793 & 1959 & 1959 & 18.802 .560 & $38.675 .024,84$ & $161.684,58$ & $1.156,42$ & $160.528,16$ & $38.514 .496,68$ \\
\hline $\mathrm{PE}$ & $\begin{array}{c}\text { Fernando de } \\
\text { Noronha }\end{array}$ & 2.718 & 544 & 544 & 5.218 .560 & $10.734 .066,94$ & $44.874,78$ & 320,96 & $44.553,82$ & $10.689 .513,12$ \\
\hline $\mathrm{PE}$ & Calumbi & 5.643 & 1129 & 1129 & 10.834 .560 & $22.285 .629,04$ & $93.167,17$ & 666,36 & $92.500,81$ & $22.193 .128,23$ \\
\hline $\mathrm{PE}$ & Salgadinho & 9.641 & 1928 & 1928 & 18.510 .720 & $38.074 .738,53$ & $159.175,02$ & $1.138,47$ & $158.036,55$ & $37.916 .701,98$ \\
\hline $\mathrm{PI}$ & Miguel Leão & 1.236 & 247 & 247 & 2.373 .120 & $4.881 .275,47$ & $20.406,63$ & 145,95 & $20.260,68$ & $4.861 .014,80$ \\
\hline $\mathrm{PI}$ & Agricolândia & 5.062 & 1012 & 1012 & 9.719 .040 & $19.991 .113,62$ & $83.574,73$ & 597,75 & $82.976,98$ & $19.908 .136,65$ \\
\hline $\mathrm{PI}$ & Beneditinos & 9.943 & 1989 & 1989 & 19.090 .560 & $39.267 .412,64$ & $164.161,11$ & $1.174,13$ & $162.986,98$ & $39.104 .425,66$ \\
\hline $\mathrm{RN}$ & Viçosa & 1.633 & 327 & 327 & 3.135 .360 & $6.449 .128,52$ & $26.961,19$ & 192,83 & $26.768,35$ & $6.422 .360,16$ \\
\hline $\mathrm{RN}$ & Sítio Novo & 5.107 & 1021 & 1021 & 9.805 .440 & $20.168 .829,96$ & $84.317,69$ & 603,07 & $83.714,62$ & $20.085 .115,34$ \\
\hline $\mathrm{RN}$ & Luís Gomes & 9.679 & 1936 & 1936 & 18.583 .680 & $38.224 .810,11$ & $159.802,41$ & $1.142,96$ & $158.659,45$ & $38.066 .150,65$ \\
\hline SE & $\begin{array}{c}\text { Amparo de São } \\
\text { Francisco }\end{array}$ & 2.290 & 458 & 458 & 4.396 .800 & $9.043 .787,08$ & $37.808,40$ & 270,42 & $37.537,98$ & $9.006 .249,10$ \\
\hline SE & Feira Nova & 5.363 & 1073 & 1073 & 10.296 .960 & $21.179 .838,48$ & $88.544,31$ & 633,30 & $87.911,01$ & $21.091 .927,47$ \\
\hline SE & $\begin{array}{l}\text { Rosário do } \\
\text { Catete }\end{array}$ & 9.541 & 1908 & 1908 & 18.318 .720 & $37.679 .813,33$ & $157.524,00$ & $1.126,66$ & $156.397,34$ & $37.523 .415,99$ \\
\hline
\end{tabular}


Os resultados globais indicam que a inclusão da variável ambiental para contabilizar os custos do empreendimento traz ganhos financeiros, sociais e ambientais à sociedade, já que um grande volume de gases poluentes para o meio ambiente deixará de ser emitido com a utilização de fontes alternativas de energia.

Para tornar mais viável a comparação entre as fontes estudadas, foram calculados os valores do kWh gerado a partir do custo do empreendimento e do custo do empreendimento com a internalização dos custos evitados, durante todo o tempo de vida útil de cada uma das fontes alternativas de energia. Também foi calculado o valor do custo evitado por kWh gerado. Os resultados são apresentados na TAB. 9.6.

TABELA 9.6 - Valores por kWh para as fontes alternativas de energia

\begin{tabular}{|c|c|c|c|c|c|}
\hline \multirow[b]{2}{*}{ Fonte } & \multicolumn{2}{|c|}{ Fotovoltaica } & \multicolumn{2}{|c|}{ Biomassa } & \multirow{2}{*}{$\begin{array}{c}\text { Energia } \\
\text { Eólica }\end{array}$} \\
\hline & Minirredes & $\begin{array}{l}\text { Sistemas } \\
\text { Isolados }\end{array}$ & $\begin{array}{l}\text { Resíduos } \\
\text { Agrícolas }\end{array}$ & $\begin{array}{c}\text { Óleo de } \\
\text { Dendê }\end{array}$ & \\
\hline $\begin{array}{c}\text { Custo do } \\
\text { empreendimento } \\
(R \$ / k W h)\end{array}$ & 1,5173 & 1,3336 & 1,7111 & 1,1654 & 2,0569 \\
\hline $\begin{array}{c}\text { Custo evitado } \\
\text { (R\$/kWh) }\end{array}$ & 0,0086 & 0,0086 & 0,0086 & 0,0086 & 0,0085 \\
\hline $\begin{array}{c}\text { Custo do } \\
\text { empreendimento } \\
\text { considerando a } \\
\text { externalidade } \\
\text { (R\$/kWh) }\end{array}$ & 1,5087 & 1,3250 & 1,7025 & 1,1568 & 2,0484 \\
\hline
\end{tabular}

A partir dos dados da tabela acima, é possível analisar as vantagens e/ou desvantagens de cada fonte e avaliar qual seria a fonte mais viável para implementação no Nordeste brasileiro.

O custo do empreendimento por kWh gerado, sem a internalização do custo ambiental variou bastante entre todas as fontes analisadas. Esses custos foram crescentes :R\$1,1654/kWh, para a biomassa de óleo de dendê; $R \$$ $1,3336 / \mathrm{kWh}$, para a energia solar fotovoltaica em sistemas isolados; $R \$$ $1,5087 / \mathrm{kWh}$, para a energia solar fotovoltaica em minirredes; $R \$ 1,7111 / \mathrm{kWh}$, para a biomassa de resíduos agrícolas e $R \$ 2,0569 / \mathrm{kWh}$, para a energia eólica. O menor custo por $\mathrm{kWh}$ gerado, durante a vida útil dos sistemas, não considerando a externalidade, é o da energia originada a partir da biomassa de óleo de dendê, e o maior custo é o da energia gerada pela energia eólica. 
Os valores da externalidade (custo evitado), que mostraram-se positivos, das fontes alternativas de energia adotadas para esse trabalho, estão muito próximos e até iguais para algumas delas, por kWh gerado. Os custos evitados de sistemas baseados em biomassa de óleo de dendê, da biomassa de resíduos agrícolas, energia solar fotovoltaica em minirredes e também em sistemas isolados, foram os maiores, em torno de $R \$ 0,0086 / \mathrm{kWh}$. A energia eólica teve o menor custo evitado: $\mathrm{R} \$ 0,0085 / \mathrm{kWh}$.

$\mathrm{Na}$ análise do custo do empreendimento, considerando a internalização da externalidade por kWh gerado, a energia obtida a partir da biomassa de óleo de dendê em análise preliminar é a que possui o resultado mais atraente. Em ordem crescente, os valores encontrados para todas as fontes foram: $R \$ R \$$ $1,1568 \mathrm{kWh}$, para a biomassa de óleo de dendê; $\mathrm{R} \$ 1,3250 / \mathrm{kWh}$, para a energia solar fotovoltaica em sistemas isolados; $R \$ 1,5087 / \mathrm{kWh}$, para a energia solar fotovoltaica em minirredes; $\mathrm{R} \$ 1,7025 / \mathrm{kWh}$, para a biomassa de resíduos agrícolas e 2,0482/kWh, para a energia eólica. A energia eólica é a menos viável economicamente, segundo os cálculos realizados. A diferença entre a fonte mais viável e a menos viável é de $77,07 \%$. Essa variação entre a primeira e a segunda mais viável é de 14,54\%, segundo a TAB. 9.7.

TABELA 9.7 - Variação percentual entre os valores por kWh das fontes alternativas de energia considerando a externalidade

\begin{tabular}{c|c|c}
\hline Fonte $^{*}$ & $\begin{array}{c}\text { Custo por } \boldsymbol{k W h} \text { gerado } \\
\text { considerando a externalidade }\end{array}$ & Variação (\%) \\
\hline Biomassa de Óleo de Dendê & 1,1568 & 0 \\
\hline $\begin{array}{c}\text { Solar Fotovoltaica em Sistemas } \\
\text { Isolados }\end{array}$ & 1,3250 & 14,54 \\
\hline $\begin{array}{c}\text { Energia Solar Fotovoltaica em } \\
\text { Minirredes }\end{array}$ & 1,5087 & 30,42 \\
\hline Biomassa de Resíduos Agrícolas & 1,7025 & 47,17 \\
\hline Eólica & 2,0484 & 77,07 \\
\hline
\end{tabular}

*Fontes classificadas por ordem crescente de valor por kWh

A partir dos resultados é possível confirmar que, após os cálculos dos custos ambientais das fontes alternativas de energia solar, biomassa e eólica, a externalidade encontrada é positiva para todas elas, ou seja, todas as fontes 
trazem benefícios ao meio ambiente e à comunidade, quando usadas para a geração de eletricidade em substituição ao óleo diesel.

Embora todas as fontes de energia alternativas aqui tratadas tragam vantagens econômicas, ambientais e sociais contribuindo para o desenvolvimento sustentável como comprovado pelos resultados, algumas fontes se destacam, devido à suas particularidades.

Em uma primeira análise, a fonte mais viável para a região nordeste é a biomassa de óleo de dendê, já que está entre as fontes com maior custo evitado na substituição pelo óleo diesel para a geração de energia elétrica, e possui o menor custo por kWh gerado. Contudo, o óleo de dendê é produzido em poucas localidades da região nordeste (alguns municípios da Bahia e Paraíba) e, se fosse adotada para toda a região, seriam acarretados custos de transporte elevados, que não foram considerados neste estudo. O transporte é um fator que eleva substancialmente o custo ambiental da fonte a ser implementada, por conta disso, adotou-se a premissa de utilização de matérias-primas produzidas localmente para a geração de energia elétrica. É preciso analisar também os usos alternativos dessa fonte, como sua utilização para fins alimentícios, que pode concorrer diretamente com a sua utilização na geração de energia elétrica, fator que pode encarecer esse combustível.

A biomassa de resíduos agrícolas é uma alternativa, quando se analisa seu custo evitado. Essa fonte foi adotada como alternativa nesse trabalho, pois pode ser amplamente aplicada no Nordeste brasileiro e é encontrada em boa parte dos municípios selecionados, fato que não ocorre com o óleo de dendê. Além disso, por se tratar de resíduos da produção, possui baixos impactos em usos concorrentes. Contudo, essa é uma fonte com custos relativamente altos para sua operacionalização.

A energia solar fotovoltaica em sistemas isolados também está entre as fontes com maior custo evitado. O seu custo por kWh ficou 14,54\% acima do óleo de dendê. A fonte de energia utilizada é abundante na região, sendo o nordeste brasileiro a localidade do país com maior disponibilidade e menor variabilidade de irradiação solar. Assim, a energia originada da fonte solar tem capacidade de aplicação em todos os municípios nordestinos, e sua utilização não possui usos concorrentes. Além disso, entre todas as configurações apresentadas, a energia solar fotovoltaica em sistemas isolados é a que tem a maior capacidade de 
fornecimento para cada família - $80 \mathrm{kWh} /$ mês. A energia gerada a partir da energia fotovoltaica em minirredes possui as mesmas vantagens dos sistemas isolados, contudo fornece $50 \mathrm{kWh} /$ mês para cada família, com um custo superior ao sistema isolado por $\mathrm{kWh}$ gerado.

A energia eólica, entre todas as alternativas analisadas, foi a fonte que apresentou o menor custo evitado, ou seja, é a fonte com menos benefícios ao meio ambiente, de acordo com os resultados. Isso pode ser justificado pelo fato dessa fonte apresentar emissões na geração de eletricidade, que em outras fontes são inexistentes. Ainda, essa fonte possui o mais elevado custo por kWh gerado entre as fontes alternativas.

É importante também considerar nas análises o tempo de vida útil de todos os sistemas e configurações estudadas. Aqueles baseados em energia solar possuem um maior tempo de vida útil, de 30 anos. Os sistemas que utilizam a biomassa de resíduos agrícolas possuem uma vida útil estimada em 25 anos e os sistemas eólicos e de biomassa de óleo de dendê, 20 anos.

Com base nos resultados e discussões apresentadas nesse capítulo, foi possível obter algumas conclusões importantes, que serão discorridas a seguir. 


\section{CONCLUSÕES}

A partir dos resultados apresentados no capítulo 9, foi possível obter algumas conclusões importantes a respeito das fontes alternativas de energia, que contribuirão para a escolha da melhor opção.

Inicialmente, analisando-se as externalidades calculadas, as fontes com mais benefícios ambientais são as biomassas de óleo de dendê e de resíduos agrícolas, como também a energia solar em suas duas configurações. A energia eólica foi a fonte com o menor custo evitado, de acordo com os resultados. Contudo, todos os valores obtidos são muito próximos, o que evidencia que todas as fontes analisadas trariam benefícios à comunidade onde os sistemas fossem implementados e, também, à sociedade como um todo.

Além dos ganhos sociais e ambientais comprovados, as fontes alternativas de energia também trazem vantagens financeiras ao projeto, já que a adoção dessas fontes possibilita retornos monetários provenientes da venda dos créditos de carbono no mercado internacional, que podem ser reinvestidos no projeto.

Partindo para a análise de viabilidade das fontes em questão, em uma primeira análise, considerando apenas os cálculos efetuados, a energia elétrica gerada a partir da biomassa de óleo de dendê é a mais viável. Contudo, uma análise mais aprofundada demonstra que, devido às particularidades de seus insumos, esse sistema não pode ser aplicado em todo o Nordeste. Mas, para aplicações isoladas, em municípios onde houver a produção local do óleo de dendê e esse não tiver outros usos prioritários, essa fonte é uma boa alternativa para a geração de energia em substituição ao óleo diesel.

A energia solar fotovoltaica em sistemas isolados demonstra ser a alternativa mais viável, pois atende a todos os municípios analisados e possui vantagens sobre as outras fontes. Ela está entre as fontes com maior custo evitado, contribuindo assim para o desenvolvimento sustentável. Além disso, foi a fonte com o segundo melhor valor por kWh gerado, após a inclusão do custo evitado, perdendo apenas para a biomassa do dendê, que não pode ser aplicada a todos os municípios. Considerando o tempo de vida útil, a energia solar 
fotovoltaica é também a melhor opção para a região nordeste, pois seu tempo de vida supera em 10 anos a do sistema de biomassa do óleo de dendê.

Vale salientar que, para aplicações isoladas, é necessário avaliar localmente as vantagens de cada uma das fontes alternativas de energia. Essa análise pode contribuir para maiores ganhos à comunidade, onde será implementado o projeto, além de reduzir os custos de produção devido ao aproveitamento da matéria-prima disponível localmente.

A seguir, são apresentadas algumas propostas de trabalhos futuros, dando continuidade a essa dissertação:

- extensão do programa PEASEB/v2 para outras fontes alternativas de energia;

- expansão da análise do custo ambiental para as fases de implantação do empreendimento e desativação das instalações geradoras de eletricidade;

- estudo de sistemas híbridos para pequenos municípios do Nordeste. 


\section{APÊNDICE A - BANCO DE DADOS DOS MUNICÍPIOS DA REGIÃO NORDESTE COM ATÉ 10.000 HABITANTES}

\begin{tabular}{|c|c|c|c|c|c|}
\hline Estado & Município & $\begin{array}{l}\text { № de habitantes } \\
\text { projetados (2012) }\end{array}$ & $\begin{array}{c}\text { Área da Unidade } \\
\text { Territorial }\left(\mathrm{km}^{2}\right)\end{array}$ & $\begin{array}{c}\text { Densidade } \\
\text { Demográfica } \\
\text { (hab/km2) }\end{array}$ & $\begin{array}{c}\mathrm{N}^{\circ} \text { de } \\
\text { Famílias } \\
\text { (5 pessoas) }\end{array}$ \\
\hline$A L$ & Barra de São Miguel & 7.755 & 76,616 & 98,86 & 1551 \\
\hline$A L$ & Belém & 4.635 & 48,630 & 83,58 & 927 \\
\hline$A L$ & Belo Monte & 6.499 & 334,146 & 21,04 & 1299,8 \\
\hline$A L$ & Campestre & 6.655 & 66,386 & 99,39 & 1331 \\
\hline$A L$ & Campo Grande & 9.273 & 167,321 & 53,98 & 1854,6 \\
\hline$A L$ & Carneiros & 8.548 & 113,061 & 73,32 & 1709,6 \\
\hline $\mathrm{AL}$ & Chã Preta & 7.146 & 172,850 & 41,34 & 1429,2 \\
\hline$A L$ & Coqueiro Seco & 5.586 & 39,730 & 139,09 & 1117,2 \\
\hline$A L$ & Feliz Deserto & 4.482 & 91,839 & 47,31 & 896,4 \\
\hline$A L$ & Jacaré dos Homens & 5.352 & 142,341 & 38,03 & 1070,4 \\
\hline$A L$ & Jacuípe & 6.950 & 210,384 & 33,26 & 1390 \\
\hline$A L$ & Japaratinga & 7.888 & 85,948 & 90,22 & 1577,6 \\
\hline $\mathrm{AL}$ & Jaramataia & 5.524 & 103,711 & 53,59 & 1104,8 \\
\hline$A L$ & Jundiá & 4.142 & 92,224 & 45,56 & 828,4 \\
\hline$A L$ & Mar Vermelho & 3.588 & 93,102 & 39,23 & 717,6 \\
\hline$A L$ & Maravilha & 9.981 & 302,057 & 34,05 & 1996,2 \\
\hline$A L$ & Minador do Negrão & 5.251 & 167,606 & 31,47 & 1050,2 \\
\hline$A L$ & Monteirópolis & 6.952 & 86,104 & 80,54 & 1390,4 \\
\hline $\mathrm{AL}$ & Olho d`Água do Casado & 8.708 & 322,945 & 26,29 & 1741,6 \\
\hline $\mathrm{AL}$ & Olho d’Água Grande & 4.967 & 118,510 & 41,83 & 993,4 \\
\hline$A L$ & Palestina & 5.201 & 48,895 & 104,55 & 1040,2 \\
\hline$A L$ & Paulo Jacinto & 7.412 & 118,457 & 62,69 & 1482,4 \\
\hline$A L$ & Pindoba & 2.857 & 117,595 & 24,37 & 571,4 \\
\hline $\mathrm{AL}$ & Porto de Pedras & 8.156 & 257,656 & 32,71 & 1631,2 \\
\hline $\mathrm{AL}$ & Roteiro & 6.607 & 129,290 & 51,48 & 1321,4 \\
\hline $\mathrm{AL}$ & Santa Luzia do Norte & 6.967 & 29,604 & 232,77 & 1393,4 \\
\hline$A L$ & São Brás & 6.744 & 139,945 & 48,00 & 1348,8 \\
\hline $\mathrm{AL}$ & São Miguel dos Milagres & 7.360 & 76,744 & 93,34 & 1472 \\
\hline $\mathrm{AL}$ & Tanque d`Arca & 6.172 & 129,509 & 47,27 & 1234,4 \\
\hline $\mathrm{BA}$ & Abaíra & 8.659 & 530,257 & 15,68 & 1731,8 \\
\hline $\mathrm{BA}$ & Aiquara & 4.536 & 159,692 & 28,82 & 907,2 \\
\hline BA & Almadina & 6.130 & 251,109 & 25,32 & 1226 \\
\hline BA & Apuarema & 7.397 & 154,857 & 48,17 & 1479,4 \\
\hline $\mathrm{BA}$ & Aratuípe & 8.632 & 181,140 & 47,47 & 1726,4 \\
\hline BA & Barra do Rocha & 6.038 & 208,352 & 30,30 & 1207,6 \\
\hline BA & Barro Preto & 6.122 & 128,381 & 50,26 & 1224,4 \\
\hline $\mathrm{BA}$ & Canápolis & 9.395 & 437,218 & 21,52 & 1879 \\
\hline $\mathrm{BA}$ & Candeal & 8.720 & 445,097 & 19,99 & 1744 \\
\hline BA & Caraíbas & 9.879 & 805,629 & 12,69 & 1975,8 \\
\hline $\mathrm{BA}$ & Cardeal da Silva & 9.030 & 256,914 & 40,30 & 1806 \\
\hline $\mathrm{BA}$ & Catolândia & 3.215 & 642,568 & 4,06 & 643 \\
\hline $\mathrm{BA}$ & Caturama & 8.817 & 664,552 & 13,31 & 1763,4 \\
\hline $\mathrm{BA}$ & Contendas do Sincorá & 4.613 & 1044,687 & 4,46 & 922,6 \\
\hline $\mathrm{BA}$ & Cordeiros & 8.245 & 535,486 & 15,25 & 1649 \\
\hline $\mathrm{BA}$ & Cravolândia & 5.048 & 162,171 & 31,09 & 1009,6 \\
\hline
\end{tabular}




\begin{tabular}{|c|c|c|c|c|c|}
\hline Estado & Município & $\begin{array}{l}\text { № de habitantes } \\
\text { projetados (2012) }\end{array}$ & $\begin{array}{l}\text { Área da Unidade } \\
\text { Territorial }\left(\mathrm{km}^{2}\right)\end{array}$ & $\begin{array}{c}\text { Densidade } \\
\text { Demográfica } \\
\text { (hab/km2) }\end{array}$ & $\begin{array}{c}\mathrm{N}^{\circ} \text { de } \\
\text { Famílias } \\
\text { (5 pessoas) }\end{array}$ \\
\hline BA & São Domingos & 9.266 & 326,947 & 28,22 & 1853,2 \\
\hline BA & São José da Vitória & 5.609 & 72,491 & 78,83 & 1121,8 \\
\hline BA & Tanquinho & 8.035 & 219,849 & 36,42 & 1607 \\
\hline BA & Teodoro Sampaio & 7.746 & 231,543 & 34,10 & 1549,2 \\
\hline BA & Várzea do Poço & 8.759 & 204,914 & 42,27 & 1751,8 \\
\hline BA & Varzedo & 8.987 & 226,796 & 40,16 & 1797,4 \\
\hline $\mathrm{BA}$ & Vereda & 6.681 & 874,332 & 7,78 & 1336,2 \\
\hline $\mathrm{BA}$ & Wagner & 8.985 & 421,004 & 21,34 & 1797 \\
\hline $\mathrm{CE}$ & Altaneira & 7.033 & 73,296 & 93,54 & 1406,6 \\
\hline $\mathrm{CE}$ & Antonina do Norte & 7.056 & 260,104 & 26,85 & 1411,2 \\
\hline CE & Arneiroz & 7.667 & 1066,362 & 7,17 & 1533,4 \\
\hline CE & Baixio & 6.072 & 146,433 & 41,15 & 1214,4 \\
\hline CE & $\begin{array}{c}\text { Deputado Irapuan } \\
\text { Pinheiro } \\
\end{array}$ & 9.203 & 470,425 & 19,33 & 1840,6 \\
\hline $\mathrm{CE}$ & Ererê & 6.922 & 382,707 & 17,27 & 1384,4 \\
\hline CE & General Sampaio & 6.423 & 205,810 & 33,23 & 1284,6 \\
\hline $\mathrm{CE}$ & Granjeiro & 4.551 & 100,127 & 46,23 & 910,2 \\
\hline CE & Guaramiranga & 3.956 & 59,436 & 41,29 & 791,2 \\
\hline $\mathrm{CE}$ & Itaiçaba & 7.428 & 212,109 & 34,86 & 1485,6 \\
\hline $\mathrm{CE}$ & Jati & 7.647 & 361,072 & 21,21 & 1529,4 \\
\hline $\mathrm{CE}$ & Moraújo & 8.225 & 415,633 & 19,42 & 1645 \\
\hline $\mathrm{CE}$ & Pacujá & 6.037 & 76,128 & 78,63 & 1207,4 \\
\hline CE & Palhano & 8.972 & 440,381 & 20,13 & 1794,4 \\
\hline CE & Penaforte & 8.483 & 141,927 & 57,96 & 1696,6 \\
\hline $\mathrm{CE}$ & Potiretama & 6.181 & 410,338 & 15,14 & 1236,2 \\
\hline $\mathrm{CE}$ & São João do Jaguaribe & 7.788 & 280,456 & 28,17 & 1557,6 \\
\hline CE & Senador Sá & 7.041 & 423,919 & 16,16 & 1408,2 \\
\hline $\mathrm{CE}$ & Tarrafas & 8.865 & 454,391 & 19,61 & 1773 \\
\hline $\mathrm{CE}$ & Umari & 7.562 & 263,930 & 28,59 & 1512,4 \\
\hline MA & Afonso Cunha & 6.090 & 371,338 & 15,90 & 1218 \\
\hline MA & Amapá do Maranhão & 6.583 & 502,402 & 12,80 & 1316,6 \\
\hline MA & Bacurituba & 5.387 & 674,512 & 7,85 & 1077,4 \\
\hline MA & Belágua & 6.986 & 499,426 & 13,06 & 1397,2 \\
\hline MA & Benedito Leite & 5.497 & 1781,734 & 3,07 & 1099,4 \\
\hline MA & Bernardo do Mearim & 6.111 & 261,451 & 22,93 & 1222,2 \\
\hline MA & Boa Vista do Gurupi & 8.375 & 403,460 & 19,70 & 1675 \\
\hline MA & Brejo de Areia & 4.962 & 362,464 & 5,26 & 992,4 \\
\hline MA & Cachoeira Grande & 8.607 & 705,645 & 11,97 & 1721,4 \\
\hline MA & Central do Maranhão & 8.120 & 319,336 & 24,72 & 1624 \\
\hline MA & Feira Nova do Maranhão & 8.215 & 1473,415 & 5,52 & 1643 \\
\hline MA & Fernando Falcão & 9.584 & 5086,584 & 1,82 & 1916,8 \\
\hline MA & Governador Luiz Rocha & 7.462 & 373,164 & 19,66 & 1492,4 \\
\hline MA & Graça Aranha & 6.150 & 271,444 & 22,62 & 1230 \\
\hline MA & Jatobá & 9.051 & 591,384 & 14,42 & 1810,2 \\
\hline MA & Junco do Maranhão & 3.792 & 555,088 & 7,24 & 758,4 \\
\hline MA & Lago dos Rodrigues & 7.744 & 180,370 & 43,21 & 1548,8 \\
\hline MA & Lajeado Novo & 7.106 & 1047,733 & 6,61 & 1421,2 \\
\hline MA & Luís Domingues & 6.629 & 464,060 & 14,03 & 1325,8 \\
\hline MA & Marajá do Sena & 7.751 & 1447,675 & 5,56 & 1550,2 \\
\hline MA & Milagres do Maranhão & 8.195 & 634,737 & 12,79 & 1639 \\
\hline
\end{tabular}




\begin{tabular}{|c|c|c|c|c|c|}
\hline Estado & Município & $\begin{array}{l}\text { № de habitantes } \\
\text { projetados (2012) }\end{array}$ & $\begin{array}{l}\text { Área da Unidade } \\
\text { Territorial }\left(\mathrm{km}^{2}\right)\end{array}$ & $\begin{array}{c}\text { Densidade } \\
\text { Demográfica } \\
\text { (hab/km2) }\end{array}$ & $\begin{array}{c}\mathrm{N}^{\circ} \text { de } \\
\text { Famílias } \\
\text { (5 pessoas) }\end{array}$ \\
\hline MA & Montes Altos & 9.272 & 1488,336 & 6,32 & 1854,4 \\
\hline MA & Nova Colinas & 5.034 & 743,106 & 6,57 & 1006,8 \\
\hline MA & Nova lorque & 4.598 & 976,853 & 4,70 & 919,6 \\
\hline MA & Porto Rico do Maranhão & 5.978 & 218,831 & 28,31 & 1195,6 \\
\hline MA & Presidente Médici & 6.564 & 437,687 & 14,56 & 1312,8 \\
\hline MA & Ribamar Fiquene & 7.444 & 750,553 & 9,75 & 1488,8 \\
\hline MA & Sambaíba & 5.522 & 2478,696 & 2,21 & 1104,4 \\
\hline MA & $\begin{array}{l}\text { Santa Filomena do } \\
\text { Maranhão }\end{array}$ & 7.246 & 602,341 & 11,72 & 1449,2 \\
\hline MA & São Domingos do Azeitão & 7.088 & 960,929 & 7,27 & 1417,6 \\
\hline MA & São Félix de Balsas & 4.636 & 2032,364 & 2,31 & 927,2 \\
\hline MA & São José dos Basílios & 7.506 & 362,692 & 20,67 & 1501,2 \\
\hline MA & São Pedro dos Crentes & 4.486 & 979,631 & 4,52 & 897,2 \\
\hline MA & $\begin{array}{c}\text { São Raimundo do Doca } \\
\text { Bezerra }\end{array}$ & 5.757 & 419,352 & 14,52 & 1151,4 \\
\hline MA & São Roberto & 6.193 & 227,463 & 26,19 & 1238,6 \\
\hline MA & Sucupira do Riachão & 5.466 & 564,968 & 8,17 & 1093,2 \\
\hline MA & Tasso Fragoso & 8.008 & 4382,975 & 1,78 & 1601,6 \\
\hline MA & Tufilândia & 5.651 & 271,010 & 20,65 & 1130,2 \\
\hline PB & Água Branca & 9.611 & 236,608 & 39,94 & 1922,2 \\
\hline PB & Aguiar & 5.514 & 344,708 & 16,04 & 1102,8 \\
\hline PB & Alcantil & 5.282 & 305,394 & 17,16 & 1056,4 \\
\hline PB & Algodão de Jandaíra & 2.390 & 220,249 & 10,74 & 478 \\
\hline PB & Amparo & 2.119 & 121,984 & 17,12 & 423,8 \\
\hline PB & Aparecida & 7.832 & 295,705 & 25,96 & 1566,4 \\
\hline PB & Areia de Baraúnas & 1.901 & 96,343 & 20,00 & 380,2 \\
\hline PB & Assunção & 3.607 & 126,427 & 27,86 & 721,4 \\
\hline PB & Baía da Traição & 8.243 & 102,369 & 78,27 & 1648,6 \\
\hline PB & Baraúna & 4.379 & 50,582 & 83,43 & 875,8 \\
\hline PB & Barra de Santana & 8.191 & 376,912 & 21,77 & 1638,2 \\
\hline PB & Barra de São Miguel & 5.679 & 595,211 & 9,43 & 1135,8 \\
\hline PB & Belém do Brejo do Cruz & 7.163 & 595,211 & 9,43 & 1432,6 \\
\hline PB & Bernardino Batista & 3.153 & 50,628 & 60,74 & 630,6 \\
\hline PB & Boa Ventura & 5.625 & 170,580 & 33,71 & 1125 \\
\hline PB & Boa Vista & 6.415 & 476,541 & 13,07 & 1283 \\
\hline PB & Bom Jesus & 2.432 & 47,631 & 50,39 & 486,4 \\
\hline PB & Bom Sucesso & 4.998 & 184,102 & 27,35 & 999,6 \\
\hline PB & Borborema & 5.169 & 25,979 & 196,74 & 1033,8 \\
\hline PB & Brejo dos Santos & 6.236 & 93,846 & 66,05 & 1247,2 \\
\hline PB & Cabaceiras & 5.148 & 452,922 & 11,12 & 1029,6 \\
\hline PB & Cachoeira dos Índios & 9.685 & 193,068 & 49,44 & 1937 \\
\hline PB & Cacimba de Areia & 3.590 & 220,380 & 16,14 & 718 \\
\hline PB & Cacimbas & 6.877 & 126,543 & 53,85 & 1375,4 \\
\hline PB & Caiçara & 7.205 & 127,914 & 56,44 & 1441 \\
\hline PB & Cajazeirinhas & 3.061 & 565,899 & 103,28 & 612,2 \\
\hline PB & Caldas Brandão & 5.710 & 55,854 & 100,92 & 1142 \\
\hline PB & Camalaú & 5.793 & 543,688 & 10,57 & 1158,6 \\
\hline PB & Capim & 5.816 & 78,167 & 71,66 & 1163,2 \\
\hline PB & Caraúbas & 3.951 & 497,204 & 7,84 & 790,2 \\
\hline PB & Carrapateira & 2.441 & 54,524 & 43,61 & 488,2 \\
\hline
\end{tabular}




\begin{tabular}{|c|c|c|c|c|c|}
\hline Estado & Município & $\begin{array}{l}\text { № de habitantes } \\
\text { projetados (2012) }\end{array}$ & $\begin{array}{l}\text { Área da Unidade } \\
\text { Territorial }\left(\mathrm{km}^{2}\right)\end{array}$ & $\begin{array}{c}\text { Densidade } \\
\text { Demográfica } \\
\text { (hab/km2) }\end{array}$ & $\begin{array}{c}\mathrm{N}^{\circ} \text { de } \\
\text { Famílias } \\
\text { (5 pessoas) }\end{array}$ \\
\hline PB & Casserengue & 7.132 & 201,381 & 35,05 & 1426,4 \\
\hline PB & Catingueira & 4.822 & 529,454 & 9,09 & 964,4 \\
\hline PB & Caturité & 4.598 & 118,081 & 38,47 & 919,6 \\
\hline PB & Condado & 6.598 & 280,916 & 23,44 & 1319,6 \\
\hline PB & Congo & 4.692 & 172,950 & 123,74 & 938,4 \\
\hline PB & Coxixola & 1.802 & 169,878 & 10,43 & 360,4 \\
\hline PB & Cubati & 6.939 & 136,967 & 50,13 & 1387,8 \\
\hline PB & Cuité de Mamanguape & 6.214 & 108,448 & 57,19 & 1242,8 \\
\hline PB & Cuitegi & 6.834 & 39,302 & 175,29 & 1366,8 \\
\hline PB & Curral de Cima & 5.192 & 85,096 & 61,21 & 1038,4 \\
\hline PB & Curral Velho & 2.497 & 222,957 & 11,24 & 499,4 \\
\hline PB & Damião & 4.990 & 185,685 & 26,39 & 998 \\
\hline PB & Desterro & 8.035 & 179,387 & 44,55 & 1607 \\
\hline PB & Diamante & 6.571 & 269,111 & 24,58 & 1314,2 \\
\hline PB & Duas Estradas & 3.611 & 26,262 & 138,53 & 722,2 \\
\hline PB & Emas & 3.356 & 240,901 & 13,77 & 671,2 \\
\hline PB & Frei Martinho & 2.935 & 244,317 & 12,00 & 587 \\
\hline PB & Gado Bravo & 8.355 & 192,406 & 43,53 & 1671 \\
\hline PB & Gurjão & 3.215 & 343,198 & 9,20 & 643 \\
\hline PB & Ibiara & 5.978 & 244,485 & 24,67 & 1195,6 \\
\hline PB & Igaracy & 6.134 & 192,260 & 32,02 & 1226,8 \\
\hline PB & Jericó & 7.557 & 179,311 & 42,04 & 1511,4 \\
\hline PB & Juarez Távora & 7.550 & 70,841 & 105,29 & 1510 \\
\hline PB & Junco do Seridó & 6.745 & 170,420 & 38,98 & 1349 \\
\hline PB & Juru & 9.793 & 403,279 & 24,37 & 1958,6 \\
\hline PB & Lagoa & 4.657 & 177,902 & 26,31 & 931,4 \\
\hline PB & Lagoa de Dentro & 7.413 & 84,508 & 87,21 & 1482,6 \\
\hline PB & Lastro & 2.800 & 102,670 & 27,67 & 560 \\
\hline PB & Livramento & 7.189 & 260,220 & 27,53 & 1437,8 \\
\hline PB & Logradouro & 4.026 & 37,996 & 103,75 & 805,2 \\
\hline PB & Mãe d’Água & 3.999 & 243,754 & 16,49 & 799,8 \\
\hline PB & Malta & 5.602 & 156,242 & 35,93 & 1120,4 \\
\hline PB & Marcação & 7.822 & 122,896 & 61,91 & 1564,4 \\
\hline PB & Marizópolis & 6.257 & 63,610 & 97,04 & 1251,4 \\
\hline PB & Mataraca & 7.641 & 184,299 & 40,19 & 1528,2 \\
\hline PB & Matinhas & 4.357 & 38,124 & 113,34 & 871,4 \\
\hline PB & Mato Grosso & 2.744 & 83,522 & 32,35 & 548,8 \\
\hline PB & Maturéia & 6.076 & 83,687 & 70,97 & 1215,2 \\
\hline PB & Montadas & 5.145 & 31,588 & 157,98 & 1029 \\
\hline PB & Monte Horebe & 4.568 & 116,173 & 38,80 & 913,6 \\
\hline PB & Mulungu & 9.542 & 195,314 & 48,48 & 1908,4 \\
\hline PB & Nazarezinho & 7.252 & 191,487 & 38,02 & 1450,4 \\
\hline PB & Nova Olinda & 6.012 & 84,253 & 72,04 & 1202,4 \\
\hline PB & Nova Palmeira & 4.480 & 310,352 & 14,05 & 896 \\
\hline PB & Olho d`Água & 6.796 & 596,129 & 11,63 & 1359,2 \\
\hline PB & Olivedos & 3.693 & 317,915 & 11,41 & 738,6 \\
\hline PB & Ouro Velho & 2.944 & 129,400 & 22,63 & 588,8 \\
\hline PB & Parari & 1.816 & 128,484 & 9,78 & 363,2 \\
\hline PB & Passagem & 2.272 & 111,876 & 19,96 & 454,4 \\
\hline
\end{tabular}




\begin{tabular}{|c|c|c|c|c|c|}
\hline Estado & Município & $\begin{array}{l}\text { № de habitantes } \\
\text { projetados (2012) }\end{array}$ & $\begin{array}{l}\text { Área da Unidade } \\
\text { Territorial }\left(\mathbf{k m}^{2}\right)\end{array}$ & $\begin{array}{c}\text { Densidade } \\
\text { Demográfica } \\
\text { (hab/km2) }\end{array}$ & $\begin{array}{l}\mathrm{N}^{\circ} \text { de } \\
\text { Famílias } \\
\text { (5 pessoas) }\end{array}$ \\
\hline PB & Pedra Branca & 3.726 & 112,933 & 32,95 & 745,2 \\
\hline PB & Pedra Lavrada & 7.605 & 351,680 & 21,26 & 1521 \\
\hline PB & Pedro Régis & 5.824 & 73,560 & 78,37 & 1164,8 \\
\hline PB & Pilões & 6.854 & 64,446 & 108,28 & 1370,8 \\
\hline PB & Pilõezinhos & 5.114 & 43,901 & 117,42 & 1022,8 \\
\hline PB & Poço Dantas & 3.740 & 97,250 & 38,57 & 748 \\
\hline PB & Poço de José de Moura & 4.046 & 100,971 & 39,40 & 809,2 \\
\hline PB & Prata & 3.919 & 192,011 & 20,07 & 783,8 \\
\hline PB & Quixabá & 1.759 & 156,683 & 10,84 & 351,8 \\
\hline PB & Riachão & 3.338 & 90,151 & 36,23 & 667,6 \\
\hline PB & Riachão do Bacamarte & 4.312 & 38,370 & 111,13 & 862,4 \\
\hline PB & Riachão do Poço & 4.235 & 39,905 & 104,35 & 847 \\
\hline PB & Riacho de Santo Antônio & 1.781 & 91,324 & 18,86 & 356,2 \\
\hline PB & Riacho dos Cavalos & 8.352 & 264,025 & 31,49 & 1670,4 \\
\hline PB & Salgadinho & 3.612 & 184,240 & 19,04 & 722,4 \\
\hline PB & Santa Cruz & 6.471 & 210,165 & 30,79 & 1294,2 \\
\hline PB & Santa Helena & 5.886 & 210,322 & 25,53 & 1177,2 \\
\hline PB & Santa Inês & 3.538 & 324,425 & 10,91 & 707,6 \\
\hline PB & Santa Teresinha & 4.559 & 357,953 & 12,80 & 911,8 \\
\hline PB & Santana de Mangueira & 5.265 & 402,152 & 13,26 & 1053 \\
\hline PB & Santana dos Garrotes & 7.173 & 353,815 & 20,54 & 1434,6 \\
\hline PB & Santo André & 2.545 & 225,169 & 11,72 & 509 \\
\hline PB & São Domingos do Cariri & 2.455 & 218,801 & 11,06 & 491 \\
\hline PB & São Francisco & 3.349 & 95,055 & 35,39 & 669,8 \\
\hline PB & São João do Cariri & 4.309 & 653,602 & 6,65 & 861,8 \\
\hline PB & São João do Tigre & 4.384 & 816,116 & 5,39 & 876,8 \\
\hline PB & $\begin{array}{c}\text { São José da Lagoa } \\
\text { Tapada }\end{array}$ & 7.560 & 341,805 & 22,13 & 1512 \\
\hline PB & São José de Caiana & 6.052 & 176,327 & 34,08 & 1210,4 \\
\hline PB & São José de Espinharas & 4.708 & 725,656 & 6,56 & 941,6 \\
\hline PB & São José de Princesa & 4.106 & 158,023 & 26,70 & 821,2 \\
\hline PB & São José do Bonfim & 3.303 & 134,724 & 24,00 & 660,6 \\
\hline PB & $\begin{array}{l}\text { São José do Brejo do } \\
\text { Cruz }\end{array}$ & 1.707 & 253,019 & 6,66 & 341,4 \\
\hline PB & São José do Sabugi & 4.027 & 206,915 & 19,38 & 805,4 \\
\hline PB & São José dos Cordeiros & 3.709 & 417,745 & 9,54 & 741,8 \\
\hline PB & São José dos Ramos & 5.600 & 98,232 & 56,07 & 1120 \\
\hline PB & São Mamede & 7.708 & 530,728 & 14,60 & 1541,6 \\
\hline PB & São Miguel de Taipu & 6.789 & 92,526 & 72,37 & 1357,8 \\
\hline PB & $\begin{array}{c}\text { São Sebastião do } \\
\text { Umbuzeiro }\end{array}$ & 3.287 & 460,573 & 7,02 & 657,4 \\
\hline PB & Serra da Raiz & 3.169 & 29,082 & 110,17 & 633,8 \\
\hline PB & Serra Grande & 2.994 & 83,474 & 35,64 & 598,8 \\
\hline PB & Serra Redonda & 7.012 & 55,905 & 126,11 & 1402,4 \\
\hline PB & Serraria & 6.175 & 65,299 & 95,53 & 1235 \\
\hline PB & Sertãozinho & 4.539 & 32,798 & 134,00 & 907,8 \\
\hline PB & Sobrado & 7.447 & 61,743 & 119,42 & 1489,4 \\
\hline PB & Sossêgo & 3.256 & 154,748 & 20,48 & 651,2 \\
\hline PB & Tenório & 2.865 & 105,271 & 26,72 & 573 \\
\hline PB & Triunfo & 9.246 & 219,866 & 41,93 & 1849,2 \\
\hline
\end{tabular}




\begin{tabular}{|c|c|c|c|c|c|}
\hline Estado & Município & $\begin{array}{l}\text { № de habitantes } \\
\text { projetados (2012) }\end{array}$ & $\begin{array}{l}\text { Área da Unidade } \\
\text { Territorial }\left(\mathbf{k m}^{2}\right)\end{array}$ & $\begin{array}{c}\text { Densidade } \\
\text { Demográfica } \\
\text { (hab/km2) }\end{array}$ & $\begin{array}{c}\mathrm{N}^{\circ} \text { de } \\
\text { Famílias } \\
\text { (5 pessoas) }\end{array}$ \\
\hline PB & Umbuzeiro & 9.698 & 181,327 & 51,28 & 1939,6 \\
\hline PB & Várzea & 2.573 & 190,447 & 13,15 & 514,6 \\
\hline PB & Vieirópolis & 5.102 & 146,779 & 34,37 & 1020,4 \\
\hline PB & Vista Serrana & 3.572 & 61,361 & 57,24 & 714,4 \\
\hline PB & Zabelê & 2.109 & 109,394 & 18,97 & 421,8 \\
\hline $\mathrm{PE}$ & Brejão & 8.834 & 159,786 & 55,35 & 1766,8 \\
\hline $\mathrm{PE}$ & Brejinho & 7.312 & 106,276 & 68,76 & 1462,4 \\
\hline $\mathrm{PE}$ & Calumbi & 5.643 & 179,314 & 31,50 & 1128,6 \\
\hline PE & Camutanga & 8.204 & 37,518 & 217,39 & 1640,8 \\
\hline $\mathrm{PE}$ & Fernando de Noronha & 2.718 & 17,017 & 154,55 & 543,6 \\
\hline PE & Granito & 6.968 & 521,942 & 13,13 & 1393,6 \\
\hline $\mathrm{PE}$ & Ibirajuba & 7.549 & 189,596 & 39,74 & 1509,8 \\
\hline $\mathrm{PE}$ & Ingazeira & 4.486 & 243,669 & 18,45 & 897,2 \\
\hline PE & Itacuruba & 4.475 & 430,033 & 10,16 & 895 \\
\hline PE & Palmeirina & 8.172 & 158,021 & 51,82 & 1634,4 \\
\hline $\mathrm{PE}$ & Quixabá & 6.722 & 210,705 & 31,98 & 1344,4 \\
\hline $\mathrm{PE}$ & Salgadinho & 9.641 & 87,217 & 104,84 & 1928,2 \\
\hline $\mathrm{PE}$ & Solidão & 5.777 & 138,399 & 41,50 & 1155,4 \\
\hline PE & Terezinha & 6.803 & 151,450 & 44,48 & 1360,6 \\
\hline $\mathrm{PE}$ & Terra Nova & 9.534 & 320,501 & 28,87 & 1906,8 \\
\hline $\mathrm{PE}$ & Tuparetama & 7.950 & 178,570 & 44,38 & 1590 \\
\hline PE & Verdejante & 9.187 & 476,039 & 19,20 & 1837,4 \\
\hline $\mathrm{PE}$ & Vertente do Lério & 7.773 & 73,631 & 106,93 & 1554,6 \\
\hline $\mathrm{PI}$ & Acauã & 6.840 & 1279,586 & 5,27 & 1368 \\
\hline $\mathrm{PI}$ & Agricolândia & 5.062 & 112,425 & 45,35 & 1012,4 \\
\hline $\mathrm{PI}$ & Alagoinha do Piauí & 7.413 & 532,981 & 13,77 & 1482,6 \\
\hline $\mathrm{PI}$ & Alegrete do Piauí & 5.173 & 282,710 & 18,23 & 1034,6 \\
\hline $\mathrm{PI}$ & Alvorada do Gurguéia & 5.177 & 2131,922 & 2,37 & 1035,4 \\
\hline $\mathrm{PI}$ & Angical do Piauí & 6.655 & 223,435 & 29,86 & 1331 \\
\hline $\mathrm{PI}$ & Anísio de Abreu & 9.385 & 337,877 & 26,93 & 1877 \\
\hline $\mathrm{PI}$ & Antônio Almeida & 3.068 & 645,745 & 4,71 & 613,6 \\
\hline $\mathrm{PI}$ & Aroazes & 5.742 & 821,663 & 7,03 & 1148,4 \\
\hline $\mathrm{PI}$ & Arraial & 4.655 & 682,760 & 6,87 & 931 \\
\hline $\mathrm{PI}$ & Assunção do Piauí & 7.590 & 1690,704 & 4,44 & 1518 \\
\hline $\mathrm{PI}$ & Barra d`Alcântara & 3.858 & 263,382 & 14,63 & 771,6 \\
\hline $\mathrm{PI}$ & Barreiras do Piauí & 3.255 & 2028,292 & 1,59 & 651 \\
\hline $\mathrm{PI}$ & Barro Duro & 6.580 & 131,119 & 50,39 & 1316 \\
\hline $\mathrm{PI}$ & Bela Vista do Piauí & 3.854 & 499,393 & 7,57 & 770,8 \\
\hline $\mathrm{PI}$ & Belém do Piauí & 3.388 & 243,282 & 13,50 & 677,6 \\
\hline $\mathrm{PI}$ & Beneditinos & 9.943 & 788,584 & 12,57 & 1988,6 \\
\hline $\mathrm{PI}$ & Bertolínia & 5.350 & 1225,336 & 4,34 & 1070 \\
\hline $\mathrm{PI}$ & Betânia do Piauí & 6.042 & 564,711 & 10,65 & 1208,4 \\
\hline $\mathrm{PI}$ & Boa Hora & 6.467 & 337,568 & 18,65 & 1293,4 \\
\hline $\mathrm{PI}$ & Bocaina & 4.394 & 268,576 & 16,27 & 878,8 \\
\hline $\mathrm{PI}$ & Bom Princípio do Piauí & 5.407 & 521,572 & 10,17 & 1081,4 \\
\hline $\mathrm{PI}$ & Bonfim do Piauí & 5.471 & 289,209 & 18,65 & 1094,2 \\
\hline $\mathrm{PI}$ & Boqueirão do Piauí & 6.288 & 278,297 & 22,25 & 1257,6 \\
\hline $\mathrm{PI}$ & Brasileira & 8.057 & 880,911 & 9,04 & 1611,4 \\
\hline $\mathrm{PI}$ & Brejo do Piauí & 3.724 & 2183,355 & 1,76 & 744,8 \\
\hline
\end{tabular}




\begin{tabular}{|c|c|c|c|c|c|}
\hline Estado & Município & $\begin{array}{l}\text { № de habitantes } \\
\text { projetados (2012) }\end{array}$ & $\begin{array}{l}\text { Área da Unidade } \\
\text { Territorial }\left(\mathrm{km}^{2}\right)\end{array}$ & $\begin{array}{c}\text { Densidade } \\
\text { Demográfica } \\
\text { (hab/km2) }\end{array}$ & $\begin{array}{c}\mathrm{N}^{\circ} \text { de } \\
\text { Famílias } \\
\text { (5 pessoas) }\end{array}$ \\
\hline $\mathrm{PI}$ & Buriti dos Montes & 8.079 & 2652,106 & 3,01 & 1615,8 \\
\hline $\mathrm{PI}$ & Cajazeiras do Piauí & 3.413 & 514,364 & 6,50 & 682,6 \\
\hline $\mathrm{PI}$ & Cajueiro da Praia & 7.321 & 271,707 & 26,36 & 1464,2 \\
\hline $\mathrm{PI}$ & $\begin{array}{c}\text { Caldeirão Grande do } \\
\text { Piauí }\end{array}$ & 5.700 & 494,892 & 11,46 & 1140 \\
\hline $\mathrm{PI}$ & Campinas do Piauí & 5.449 & 831,201 & 6,51 & 1089,8 \\
\hline $\mathrm{PI}$ & Campo Alegre do Fidalgo & 4.815 & 657,796 & 7,13 & 963 \\
\hline $\mathrm{PI}$ & Campo Grande do Piauí & 5.704 & 311,829 & 17,93 & 1140,8 \\
\hline $\mathrm{PI}$ & Campo Largo do Piauí & 6.964 & 477,795 & 14,24 & 1392,8 \\
\hline $\mathrm{PI}$ & Canavieira & 3.892 & 2162,874 & 1,81 & 778,4 \\
\hline $\mathrm{PI}$ & Capitão Gervásio Oliveira & 3.946 & 1134,168 & 3,42 & 789,2 \\
\hline $\mathrm{PI}$ & Caraúbas do Piauí & 5.634 & 471,453 & 11,72 & 1126,8 \\
\hline $\mathrm{PI}$ & Caridade do Piauí & 4.915 & 501,359 & 9,63 & 983 \\
\hline $\mathrm{PI}$ & Caxingó & 5.174 & 488,169 & 10,32 & 1034,8 \\
\hline $\mathrm{PI}$ & Cocal de Telha & 4.567 & 282,105 & 16,04 & 913,4 \\
\hline $\mathrm{PI}$ & Cocal dos Alves & 5.635 & 357,689 & 15,58 & 1127 \\
\hline $\mathrm{PI}$ & Coivaras & 3.872 & 485,496 & 7,85 & 774,4 \\
\hline $\mathrm{PI}$ & Colônia do Gurguéia & 6.191 & 430,621 & 14,02 & 1238,2 \\
\hline $\mathrm{PI}$ & Colônia do Piauí & 7.461 & 947,873 & 7,84 & 1492,2 \\
\hline $\mathrm{PI}$ & Conceição do Canindé & 4.496 & 831,412 & 5,38 & 899,2 \\
\hline $\mathrm{PI}$ & Coronel José Dias & 4.561 & 1914,819 & 2,37 & 912,2 \\
\hline $\mathrm{PI}$ & Cristalândia do Piauí & 7.973 & 1202,895 & 6,51 & 1594,6 \\
\hline $\mathrm{PI}$ & Currais & 4.776 & 3156,658 & 1,49 & 955,2 \\
\hline $\mathrm{PI}$ & Curral Novo do Piauí & 4.990 & 752,312 & 6,47 & 998 \\
\hline $\mathrm{PI}$ & Curralinhos & 4.265 & 345,848 & 12,09 & 853 \\
\hline $\mathrm{PI}$ & Dirceu Arcoverde & 6.767 & 1017,057 & 6,56 & 1353,4 \\
\hline $\mathrm{PI}$ & Dom Expedito Lopes & 6.662 & 219,073 & 29,99 & 1332,4 \\
\hline $\mathrm{PI}$ & Dom Inocêncio & 9.296 & 3870,167 & 2,39 & 1859,2 \\
\hline $\mathrm{PI}$ & Domingos Mourão & 4.261 & 846,844 & 5,04 & 852,2 \\
\hline $\mathrm{PI}$ & Eliseu Martins & 4.738 & 1090,450 & 4,28 & 947,6 \\
\hline $\mathrm{PI}$ & Fartura do Piauí & 5.133 & 712,918 & 7,12 & 1026,6 \\
\hline $\mathrm{PI}$ & Flores do Piauí & 4.366 & 946,731 & 4,61 & 873,2 \\
\hline $\mathrm{PI}$ & Floresta do Piauí & 2.492 & 194,699 & 12,75 & 498,4 \\
\hline $\mathrm{PI}$ & Francinópolis & 5.233 & 268,701 & 19,48 & 1046,6 \\
\hline $\mathrm{PI}$ & Francisco Ayres & 4.363 & 656,475 & 6,82 & 872,6 \\
\hline $\mathrm{PI}$ & Francisco Macedo & 2.961 & 155,279 & 18,54 & 592,2 \\
\hline $\mathrm{PI}$ & Francisco Santos & 8.857 & 491,862 & 17,47 & 1771,4 \\
\hline $\mathrm{PI}$ & Geminiano & 5.237 & 462,523 & 11,84 & 1047,4 \\
\hline $\mathrm{PI}$ & Guaribas & 4.432 & 3118,227 & 1,41 & 886,4 \\
\hline $\mathrm{PI}$ & Hugo Napoleão & 3.782 & 224,455 & 16,80 & 756,4 \\
\hline $\mathrm{PI}$ & Ilha Grande & 9.069 & 134,318 & 66,37 & 1813,8 \\
\hline $\mathrm{PI}$ & Ipiranga do Piauí & 9.463 & 527,727 & 17,67 & 1892,6 \\
\hline $\mathrm{PI}$ & Isaías Coelho & 8.307 & 776,053 & 10,59 & 1661,4 \\
\hline $\mathrm{PI}$ & Jacobina do Piauí & 5.670 & 1370,699 & 4,17 & 1134 \\
\hline $\mathrm{PI}$ & Jardim do Mulato & 4.358 & 509,851 & 8,45 & 871,6 \\
\hline $\mathrm{PI}$ & Jatobá do Piauí & 4.708 & 653,234 & 7,13 & 941,6 \\
\hline $\mathrm{PI}$ & Jerumenha & 4.372 & 1867,313 & 2,35 & 874,4 \\
\hline $\mathrm{PI}$ & João Costa & 2.951 & 1800,243 & 1,64 & 590,2 \\
\hline $\mathrm{PI}$ & Joca Marques & 5.214 & 166,443 & 30,64 & 1042,8 \\
\hline $\mathrm{PI}$ & Juazeiro do Piauí & 4.793 & 827,240 & 5,75 & 958,6 \\
\hline
\end{tabular}




\begin{tabular}{|c|c|c|c|c|c|}
\hline Estado & Município & $\begin{array}{l}\text { № de habitantes } \\
\text { projetados (2012) }\end{array}$ & $\begin{array}{l}\text { Área da Unidade } \\
\text { Territorial }\left(\mathbf{k m}^{2}\right)\end{array}$ & $\begin{array}{c}\text { Densidade } \\
\text { Demográfica } \\
\text { (hab/km2) }\end{array}$ & $\begin{array}{c}\mathrm{N}^{\circ} \text { de } \\
\text { Famílias } \\
\text { (5 pessoas) }\end{array}$ \\
\hline $\mathrm{PI}$ & Júlio Borges & 5.439 & 1297,108 & 4,14 & 1087,8 \\
\hline $\mathrm{PI}$ & Jurema & 4.588 & 1271,889 & 3,55 & 917,6 \\
\hline $\mathrm{PI}$ & Lagoa Alegre & 8.184 & 394,661 & 20,29 & 1636,8 \\
\hline $\mathrm{PI}$ & Lagoa de São Francisco & 6.517 & 155,639 & 41,26 & 1303,4 \\
\hline $\mathrm{PI}$ & Lagoa do Barro do Piauí & 4.535 & 1261,941 & 3,58 & 907 \\
\hline $\mathrm{PI}$ & Lagoa do Piauí & 3.920 & 426,634 & 9,05 & 784 \\
\hline $\mathrm{PI}$ & Lagoa do Sítio & 4.958 & 804,698 & 6,03 & 991,6 \\
\hline $\mathrm{PI}$ & Lagoinha do Piauí & 2.721 & 67,504 & 39,35 & 544,2 \\
\hline $\mathrm{PI}$ & Landri Sales & 5.229 & 1088,583 & 4,85 & 1045,8 \\
\hline $\mathrm{PI}$ & Madeiro & 7.974 & 177,153 & 44,12 & 1594,8 \\
\hline $\mathrm{PI}$ & Manoel Emídio & 5.223 & 1618,982 & 3,22 & 1044,6 \\
\hline $\mathrm{PI}$ & Marcolândia & 8.059 & 143,876 & 54,30 & 1611,8 \\
\hline $\mathrm{PI}$ & Marcos Parente & 4.453 & 677,414 & 6,58 & 890,6 \\
\hline $\mathrm{PI}$ & Massapê do Piauí & 6.260 & 521,125 & 11,94 & 1252 \\
\hline $\mathrm{PI}$ & Miguel Leão & 1.236 & 1393,714 & 23,17 & 247,2 \\
\hline $\mathrm{PI}$ & Milton Brandão & 6.750 & 1371,743 & 4,93 & 1350 \\
\hline $\mathrm{PI}$ & Monsenhor Hipólito & 7.486 & 401,433 & 18,41 & 1497,2 \\
\hline $\mathrm{PI}$ & Morro Cabeça no Tempo & 4.053 & 2116,936 & 1,92 & 810,6 \\
\hline $\mathrm{PI}$ & Morro do Chapéu do Piauí & 6.574 & 328,289 & 19,80 & 1314,8 \\
\hline $\mathrm{PI}$ & Murici dos Portelas & 8.714 & 481,707 & 17,57 & 1742,8 \\
\hline $\mathrm{PI}$ & Nazaré do Piauí & 7.248 & 1315,839 & 5,56 & 1449,6 \\
\hline $\mathrm{PI}$ & Nossa Senhora de Nazaré & 4.661 & 356,264 & 12,79 & 932,2 \\
\hline $\mathrm{PI}$ & $\begin{array}{l}\text { Nossa Senhora dos } \\
\text { Remédios }\end{array}$ & 8.356 & 358,492 & 22,89 & 1671,2 \\
\hline $\mathrm{PI}$ & Nova Santa Rita & 4.233 & 909,735 & 4,60 & 846,6 \\
\hline $\mathrm{PI}$ & Novo Oriente do Piauí & 6.459 & 525,334 & 12,37 & 1291,8 \\
\hline $\mathrm{PI}$ & Novo Santo Antônio & 3.329 & 481,707 & 6,77 & 665,8 \\
\hline $\mathrm{PI}$ & Olho d`Água do Piauí & 2.678 & 219,598 & 11,96 & 535,6 \\
\hline $\mathrm{PI}$ & Padre Marcos & 6.687 & 272,035 & 24,47 & 1337,4 \\
\hline $\mathrm{PI}$ & Paes Landim & 4.049 & 401,378 & 10,11 & 809,8 \\
\hline $\mathrm{PI}$ & Pajeú do Piauí & 3.434 & 1079,172 & 3,12 & 686,8 \\
\hline $\mathrm{PI}$ & Palmeira do Piauí & 4.962 & 2023,512 & 2,47 & 992,4 \\
\hline $\mathrm{PI}$ & Paquetá & 3.891 & 448,459 & 9,25 & 778,2 \\
\hline PI & $\begin{array}{c}\text { Passagem Franca do } \\
\text { Piauí }\end{array}$ & 4.424 & 849,608 & 5,35 & 884,8 \\
\hline $\mathrm{PI}$ & Patos do Piauí & 6.178 & 751,598 & 8,12 & 1235,6 \\
\hline $\mathrm{PI}$ & Pavussu & 3.629 & 1090,697 & 3,36 & 725,8 \\
\hline $\mathrm{PI}$ & Pedro Laurentino & 2.445 & 870,338 & 2,77 & 489 \\
\hline $\mathrm{PI}$ & Porto Alegre do Piauí & 2.606 & 1169,444 & 2,19 & 521,2 \\
\hline $\mathrm{PI}$ & Prata do Piauí & 3.088 & 196,326 & 15,71 & 617,6 \\
\hline $\mathrm{PI}$ & Queimada Nova & 8.679 & 1352,398 & 6,32 & 1735,8 \\
\hline $\mathrm{PI}$ & Redenção do Gurguéia & 8.494 & 2468,007 & 3,40 & 1698,8 \\
\hline $\mathrm{PI}$ & Riacho Frio & 4.229 & 2222,096 & 1,91 & 845,8 \\
\hline $\mathrm{PI}$ & Ribeira do Piauí & 4.321 & 1004,227 & 4,25 & 864,2 \\
\hline $\mathrm{PI}$ & Ribeiro Gonçalves & 7.015 & 3978,962 & 1,72 & 1403 \\
\hline $\mathrm{PI}$ & Rio Grande do Piauí & 6.282 & 635,951 & 9,86 & 1256,4 \\
\hline $\mathrm{PI}$ & Santa Cruz do Piauí & 6.065 & 611,617 & 9,85 & 1213 \\
\hline $\mathrm{PI}$ & Santa Cruz dos Milagres & 3.864 & 979,657 & 3,87 & 772,8 \\
\hline
\end{tabular}




\begin{tabular}{|c|c|c|c|c|c|}
\hline Estado & Município & $\begin{array}{l}\text { № de habitantes } \\
\text { projetados (2012) }\end{array}$ & $\begin{array}{l}\text { Área da Unidade } \\
\text { Territorial }\left(\mathbf{k m}^{2}\right)\end{array}$ & $\begin{array}{c}\text { Densidade } \\
\text { Demográfica } \\
\text { (hab/km2) }\end{array}$ & $\begin{array}{c}\mathrm{N}^{\circ} \text { de } \\
\text { Famílias } \\
\text { (5 pessoas) }\end{array}$ \\
\hline $\mathrm{PI}$ & Santa Filomena & 6.106 & 5285,438 & 1,15 & 1221,2 \\
\hline $\mathrm{PI}$ & Santa Luz & 5.624 & 1186,843 & 4,65 & 1124,8 \\
\hline $\mathrm{PI}$ & Santa Rosa do Piauí & 5.145 & 340,198 & 15,14 & 1029 \\
\hline $\mathrm{PI}$ & Santana do Piauí & 4.489 & 141,118 & 34,84 & 897,8 \\
\hline $\mathrm{PI}$ & Santo Antônio de Lisboa & 6.136 & 387,403 & 15,51 & 1227,2 \\
\hline PI & $\begin{array}{l}\text { Santo Antônio dos } \\
\text { Milagres }\end{array}$ & 2.087 & 33,147 & 62,12 & 417,4 \\
\hline $\mathrm{PI}$ & Santo Inácio do Piauí & 3.679 & 852,892 & 4,28 & 735,8 \\
\hline $\mathrm{PI}$ & São Braz do Piauí & 4.332 & 656,361 & 6,57 & 866,4 \\
\hline $\mathrm{PI}$ & São Félix do Piauí & 2.925 & 657,244 & 4,67 & 585 \\
\hline $\mathrm{PI}$ & $\begin{array}{c}\text { São Francisco de Assis } \\
\text { do Piauí }\end{array}$ & 5.686 & 1100,398 & 5,06 & 1137,2 \\
\hline $\mathrm{PI}$ & São Francisco do Piauí & 6.290 & 1340,665 & 4,70 & 1258 \\
\hline $\mathrm{PI}$ & São Gonçalo do Gurguéia & 2.901 & 1385,299 & 2,04 & 580,2 \\
\hline $\mathrm{PI}$ & São Gonçalo do Piauí & 4.831 & 150,215 & 31,65 & 966,2 \\
\hline $\mathrm{PI}$ & São João da Canabrava & 4.476 & 480,280 & 9,26 & 895,2 \\
\hline $\mathrm{PI}$ & São João da Fronteira & 5.718 & 764,866 & 7,33 & 1143,6 \\
\hline $\mathrm{PI}$ & São João da Serra & 6.079 & 1006,500 & 6,12 & 1215,8 \\
\hline $\mathrm{PI}$ & São João da Varjota & 4.693 & 395,306 & 11,77 & 938,6 \\
\hline $\mathrm{PI}$ & São João do Arraial & 7.578 & 213,355 & 34,38 & 1515,6 \\
\hline $\mathrm{PI}$ & São José do Divino & 5.189 & 319,130 & 16,13 & 1037,8 \\
\hline $\mathrm{PI}$ & São José do Peixe & 3.682 & 1287,174 & 2,87 & 736,4 \\
\hline $\mathrm{PI}$ & São José do Piauí & 6.574 & 364,945 & 18,06 & 1314,8 \\
\hline $\mathrm{PI}$ & São Julião & 5.719 & 257,191 & 22,07 & 1143,8 \\
\hline $\mathrm{PI}$ & São Lourenço do Piauí & 4.451 & 672,709 & 6,58 & 890,2 \\
\hline $\mathrm{PI}$ & São Luis do Piauí & 2.573 & 220,375 & 11,62 & 514,6 \\
\hline $\mathrm{PI}$ & $\begin{array}{l}\text { São Miguel da Baixa } \\
\text { Grande }\end{array}$ & 2.386 & 384,192 & 5,49 & 477,2 \\
\hline $\mathrm{PI}$ & São Miguel do Fidalgo & 2.974 & 813,444 & 3,66 & 594,8 \\
\hline $\mathrm{PI}$ & Sebastião Barros & 3.475 & 893,715 & 3,98 & 695 \\
\hline $\mathrm{PI}$ & Sebastião Leal & 4.159 & 3151,592 & 1,31 & 831,8 \\
\hline $\mathrm{PI}$ & Sigefredo Pacheco & 9.706 & 966,989 & 9,95 & 1941,2 \\
\hline $\mathrm{PI}$ & Socorro do Piauí & 4.495 & 761,854 & 5,94 & 899 \\
\hline $\mathrm{PI}$ & Sussuapara & 6.409 & 209,700 & 29,70 & 1281,8 \\
\hline $\mathrm{PI}$ & Tamboril do Piauí & 2.805 & 1587,296 & 1,73 & 561 \\
\hline $\mathrm{PI}$ & Tanque do Piauí & 2.663 & 398,723 & 6,57 & 532,6 \\
\hline $\mathrm{PI}$ & Várzea Branca & 4.875 & 450,755 & 10,90 & 975 \\
\hline $\mathrm{PI}$ & Várzea Grande & 4.316 & 237,013 & 18,29 & 863,2 \\
\hline $\mathrm{PI}$ & Vera Mendes & 2.998 & 341,974 & 8,73 & 599,6 \\
\hline $\mathrm{PI}$ & Vila Nova do Piauí & 2.990 & 218,316 & 14,09 & 598 \\
\hline $\mathrm{PI}$ & Wall Ferraz & 4.323 & 269,987 & 15,85 & 864,6 \\
\hline $\mathrm{RN}$ & Água Nova & 3.026 & 50,684 & 58,80 & 605,2 \\
\hline $\mathrm{RN}$ & Almino Afonso & 4.823 & 128,038 & 38,04 & 964,6 \\
\hline $\mathrm{RN}$ & Antônio Martins & 6.930 & 244,623 & 28,24 & 1386 \\
\hline $\mathrm{RN}$ & Augusto Severo & 9.330 & 896,954 & 10,36 & 1866 \\
\hline $\mathrm{RN}$ & Baía Formosa & 8.687 & 245,661 & 34,90 & 1737,4 \\
\hline $\mathrm{RN}$ & Barcelona & 3.944 & 152,626 & 25,88 & 788,8 \\
\hline $\mathrm{RN}$ & Bento Fernandes & 5.175 & 301,070 & 16,98 & 1035 \\
\hline $\mathrm{RN}$ & Bodó & 2.373 & 253,519 & 9,57 & 474,6 \\
\hline $\mathrm{RN}$ & Bom Jesus & 9.566 & 122,038 & 77,35 & 1913,2 \\
\hline
\end{tabular}




\begin{tabular}{|c|c|c|c|c|c|}
\hline Estado & Município & $\begin{array}{l}\text { № de habitantes } \\
\text { projetados (2012) }\end{array}$ & $\begin{array}{l}\text { Área da Unidade } \\
\text { Territorial }\left(\mathbf{k m}^{2}\right)\end{array}$ & $\begin{array}{c}\text { Densidade } \\
\text { Demográfica } \\
\text { (hab/km2) }\end{array}$ & $\begin{array}{c}\mathrm{N}^{\circ} \text { de } \\
\text { Famílias } \\
\text { (5 pessoas) }\end{array}$ \\
\hline $\mathrm{RN}$ & Caiçara do Norte & 6.043 & 189,550 & 31,74 & 1208,6 \\
\hline $\mathrm{RN}$ & Caiçara do Rio do Vento & 3.375 & 261,194 & 12,67 & 675 \\
\hline $\mathrm{RN}$ & Carnaúba dos Dantas & 7.559 & 245,651 & 30,24 & 1511,8 \\
\hline $\mathrm{RN}$ & Coronel Ezequiel & 5.405 & 185,748 & 29,10 & 1081 \\
\hline $\mathrm{RN}$ & Coronel João Pessoa & 4.783 & 117,139 & 40,74 & 956,6 \\
\hline $\mathrm{RN}$ & Cruzeta & 7.942 & 295,830 & 26,93 & 1588,4 \\
\hline $\mathrm{RN}$ & Doutor Severiano & 6.954 & 108,279 & 59,96 & 1390,8 \\
\hline $\mathrm{RN}$ & Encanto & 5.297 & 125,749 & 41,60 & 1059,4 \\
\hline $\mathrm{RN}$ & Equador & 5.846 & 264,985 & 21,97 & 1169,2 \\
\hline $\mathrm{RN}$ & Felipe Guerra & 5.765 & 268,588 & 21,35 & 1153 \\
\hline $\mathrm{RN}$ & Fernando Pedroza & 2.885 & 322,628 & 8,85 & 577 \\
\hline $\mathrm{RN}$ & Florânia & 8.957 & 504,797 & 17,74 & 1791,4 \\
\hline $\mathrm{RN}$ & Francisco Dantas & 2.852 & 181,558 & 15,83 & 570,4 \\
\hline $\mathrm{RN}$ & Frutuoso Gomes & 4.181 & 63,279 & 66,89 & 836,2 \\
\hline $\mathrm{RN}$ & Galinhos & 2.284 & 342,215 & 6,31 & 456,8 \\
\hline $\mathrm{RN}$ & Grossos & 9.566 & 126,458 & 74,28 & 1913,2 \\
\hline $\mathrm{RN}$ & Ipueira & 2.104 & 127,348 & 16,31 & 420,8 \\
\hline $\mathrm{RN}$ & Itajá & 7.036 & 203,622 & 34,04 & 1407,2 \\
\hline $\mathrm{RN}$ & Itaú & 5.609 & 133,029 & 41,83 & 1121,8 \\
\hline $\mathrm{RN}$ & Jaçanã & 8.150 & 54,561 & 145,25 & 1630 \\
\hline $\mathrm{RN}$ & Jandaíra & 6.838 & 435,947 & 15,60 & 1367,6 \\
\hline $\mathrm{RN}$ & Janduís & 5.307 & 304,901 & 17,53 & 1061,4 \\
\hline $\mathrm{RN}$ & Januário Cicco & 9.211 & 187,213 & 48,13 & 1842,2 \\
\hline $\mathrm{RN}$ & Japi & 5.401 & 188,991 & 29,22 & 1080,2 \\
\hline $\mathrm{RN}$ & Jardim de Angicos & 2.598 & 254,022 & 10,26 & 519,6 \\
\hline $\mathrm{RN}$ & João Dias & 2.602 & 88,173 & 29,50 & 520,4 \\
\hline $\mathrm{RN}$ & José da Penha & 5.862 & 117,635 & 49,88 & 1172,4 \\
\hline $\mathrm{RN}$ & Jundiá & 3.635 & 44,641 & 80,24 & 727 \\
\hline $\mathrm{RN}$ & Lagoa de Pedras & 7.079 & 117,663 & 59,40 & 1415,8 \\
\hline $\mathrm{RN}$ & Lagoa de Velhos & 2.671 & 112,845 & 23,64 & 534,2 \\
\hline $\mathrm{RN}$ & Lagoa d`Anta & 6.318 & 105,652 & 58,94 & 1263,6 \\
\hline $\mathrm{RN}$ & Lagoa Salgada & 7.679 & 79,330 & 95,37 & 1535,8 \\
\hline $\mathrm{RN}$ & Lajes Pintadas & 4.625 & 130,211 & 35,42 & 925 \\
\hline $\mathrm{RN}$ & Lucrécia & 3.696 & 30,931 & 117,45 & 739,2 \\
\hline $\mathrm{RN}$ & Luís Gomes & 9.679 & 166,638 & 57,67 & 1935,8 \\
\hline $\mathrm{RN}$ & Major Sales & 3.625 & 31,971 & 110,60 & 725 \\
\hline $\mathrm{RN}$ & Marcelino Vieira & 8.249 & 345,711 & 23,91 & 1649,8 \\
\hline $\mathrm{RN}$ & Martins & 8.293 & 169,464 & 48,49 & 1658,6 \\
\hline $\mathrm{RN}$ & Messias Targino & 4.259 & 135,097 & 31,00 & 851,8 \\
\hline $\mathrm{RN}$ & Monte das Gameleiras & 2.219 & 71,946 & 31,43 & 443,8 \\
\hline $\mathrm{RN}$ & Olho-d`Água do Borges & 4.270 & 141,170 & 30,42 & 854 \\
\hline $\mathrm{RN}$ & Ouro Branco & 4.704 & 253,304 & 18,55 & 940,8 \\
\hline $\mathrm{RN}$ & Paraná & 4.001 & 81,390 & 48,56 & 800,2 \\
\hline $\mathrm{RN}$ & Paraú & 3.824 & 383,214 & 10,07 & 764,8 \\
\hline $\mathrm{RN}$ & Parazinho & 4.924 & 274,674 & 17,64 & 984,8 \\
\hline $\mathrm{RN}$ & Passagem & 2.925 & 41,215 & 70,24 & 585 \\
\hline $\mathrm{RN}$ & Pedra Grande & 3.447 & 221,423 & 15,90 & 689,4 \\
\hline $\mathrm{RN}$ & Pedra Preta & 2.552 & 294,985 & 8,78 & 510,4 \\
\hline $\mathrm{RN}$ & Pedro Avelino & 7.045 & 952,759 & 7,53 & 1409 \\
\hline
\end{tabular}




\begin{tabular}{|c|c|c|c|c|c|}
\hline Estado & Município & $\begin{array}{l}\text { № de habitantes } \\
\text { projetados (2012) }\end{array}$ & $\begin{array}{l}\text { Área da Unidade } \\
\text { Territorial }\left(\mathrm{km}^{2}\right)\end{array}$ & $\begin{array}{c}\text { Densidade } \\
\text { Demográfica } \\
\text { (hab/km2) }\end{array}$ & $\begin{array}{c}\mathrm{N}^{\circ} \text { de } \\
\text { Famílias } \\
\text { (5 pessoas) }\end{array}$ \\
\hline $\mathrm{RN}$ & Pilões & 3.522 & 82,690 & 41,76 & 704,4 \\
\hline $\mathrm{RN}$ & Portalegre & 7.407 & 110,054 & 66,51 & 1481,4 \\
\hline $\mathrm{RN}$ & Porto do Mangue & 5.392 & 318,968 & 16,36 & 1078,4 \\
\hline $\mathrm{RN}$ & Presidente Juscelino & 9.035 & 167,345 & 52,40 & 1807 \\
\hline $\mathrm{RN}$ & Pureza & 8.645 & 504,295 & 16,70 & 1729 \\
\hline $\mathrm{RN}$ & Rafael Fernandes & 4.760 & 78,231 & 59,98 & 952 \\
\hline $\mathrm{RN}$ & Rafael Godeiro & 3.080 & 100,073 & 30,61 & 616 \\
\hline $\mathrm{RN}$ & Riacho da Cruz & 3.241 & 127,223 & 24,88 & 648,2 \\
\hline $\mathrm{RN}$ & Riacho de Santana & 4.150 & 128,106 & 32,44 & 830 \\
\hline $\mathrm{RN}$ & Riachuelo & 7.265 & 262,887 & 26,88 & 1453 \\
\hline $\mathrm{RN}$ & Rodolfo Fernandes & 4.411 & 154,840 & 28,53 & 882,2 \\
\hline $\mathrm{RN}$ & Ruy Barbosa & 3.582 & 125,809 & 28,58 & 716,4 \\
\hline $\mathrm{RN}$ & Santa Maria & 4.911 & 219,569 & 21,69 & 982,2 \\
\hline $\mathrm{RN}$ & Santana do Seridó & 2.549 & 188,404 & 13,41 & 509,8 \\
\hline $\mathrm{RN}$ & São Bento do Norte & 2.915 & 288,725 & 10,30 & 583 \\
\hline $\mathrm{RN}$ & São Bento do Trairí & 4.005 & 190,818 & 20,46 & 801 \\
\hline $\mathrm{RN}$ & São Fernando & 3.427 & 404,428 & 8,41 & 685,4 \\
\hline $\mathrm{RN}$ & São Francisco do Oeste & 3.934 & 75,588 & 51,25 & 786,8 \\
\hline $\mathrm{RN}$ & São João do Sabugi & 5.956 & 277,012 & 21,38 & 1191,2 \\
\hline $\mathrm{RN}$ & São José do Seridó & 4.300 & 174,505 & 24,25 & 860 \\
\hline $\mathrm{RN}$ & São Pedro & 6.154 & 195,238 & 31,94 & 1230,8 \\
\hline $\mathrm{RN}$ & São Rafael & 8.098 & 469,102 & 17,29 & 1619,6 \\
\hline $\mathrm{RN}$ & São Vicente & 6.088 & 197,817 & 30,47 & 1217,6 \\
\hline $\mathrm{RN}$ & Serra de São Bento & 5.724 & 96,627 & 59,43 & 1144,8 \\
\hline $\mathrm{RN}$ & Serra Negra do Norte & 7.805 & 562,397 & 13,82 & 1561 \\
\hline $\mathrm{RN}$ & Serrinha & 6.480 & 193,351 & 34,04 & 1296 \\
\hline $\mathrm{RN}$ & Serrinha dos Pintos & 4.577 & 122,649 & 37,02 & 915,4 \\
\hline $\mathrm{RN}$ & Severiano Melo & 5.848 & 157,851 & 36,44 & 1169,6 \\
\hline $\mathrm{RN}$ & Sítio Novo & 5.107 & 213,459 & 23,52 & 1021,4 \\
\hline $\mathrm{RN}$ & Taboleiro Grande & 2.361 & 124,094 & 18,67 & 472,2 \\
\hline $\mathrm{RN}$ & Tenente Laurentino Cruz & 5.557 & 74,376 & 72,68 & 1111,4 \\
\hline $\mathrm{RN}$ & Tibau & 3.761 & 169,237 & 21,79 & 752,2 \\
\hline $\mathrm{RN}$ & Timbaúba dos Batistas & 2.312 & 135,454 & 16,94 & 462,4 \\
\hline $\mathrm{RN}$ & Triunfo Potiguar & 3.327 & 268,726 & 12,53 & 665,4 \\
\hline $\mathrm{RN}$ & Várzea & 5.271 & 72,684 & 72,04 & 1054,2 \\
\hline $\mathrm{RN}$ & Venha-Ver & 3.882 & 71,622 & 53,35 & 776,4 \\
\hline $\mathrm{RN}$ & Viçosa & 1.633 & 37,905 & 42,69 & 326,6 \\
\hline $\mathrm{RN}$ & Vila Flor & 2.924 & 47,656 & 60,27 & 584,8 \\
\hline SE & Amparo de São Francisco & 2.290 & 35,133 & 64,75 & 458 \\
\hline SE & Arauá & 9.495 & 198,746 & 56,44 & 1899 \\
\hline SE & Brejo Grande & 7.839 & 148,858 & 52,01 & 1567,8 \\
\hline SE & Canhoba & 3.955 & 170,289 & 23,23 & 791 \\
\hline SE & Cedro de São João & 5.672 & 83,710 & 67,29 & 1134,4 \\
\hline SE & Cumbe & 3.839 & 128,597 & 29,65 & 767,8 \\
\hline SE & Divina Pastora & 4.487 & 91,792 & 47,13 & 897,4 \\
\hline SE & Feira Nova & 5.363 & 184,933 & 28,79 & 1072,6 \\
\hline SE & General Maynard & 3.009 & 19,975 & 146,63 & 601,8 \\
\hline SE & Gracho Cardoso & 5.665 & 242,062 & 23,32 & 1133 \\
\hline SE & Ilha das Flores & 8.359 & 54,640 & 152,78 & 1671,8 \\
\hline
\end{tabular}




\begin{tabular}{|c|c|c|c|c|c|}
\hline Estado & Município & $\begin{array}{l}\text { № de habitantes } \\
\text { projetados (2012) }\end{array}$ & $\begin{array}{l}\text { Área da Unidade } \\
\text { Territorial }\left(\mathrm{km}^{2}\right)\end{array}$ & $\begin{array}{c}\text { Densidade } \\
\text { Demográfica } \\
\text { (hab/km2) }\end{array}$ & $\begin{array}{c}\mathrm{N}^{\circ} \text { de } \\
\text { Famílias } \\
\text { (5 pessoas) }\end{array}$ \\
\hline SE & Itabi & 4.942 & 184,423 & 26,96 & 988,4 \\
\hline SE & Macambira & 6.492 & 136,937 & 46,74 & 1298,4 \\
\hline SE & Malhada dos Bois & 3.494 & 63,199 & 54,68 & 698,8 \\
\hline SE & Muribeca & 7.381 & 75,863 & 96,81 & 1476,2 \\
\hline SE & Nossa Senhora Aparecida & 8.543 & 340,380 & 25,00 & 1708,6 \\
\hline SE & $\begin{array}{c}\text { Nossa Senhora de } \\
\text { Lourdes }\end{array}$ & 6.271 & 81,061 & 76,95 & 1254,2 \\
\hline SE & Pedra Mole & 3.026 & 82,026 & 36,26 & 605,2 \\
\hline SE & Pedrinhas & 8.970 & 33,942 & 260,25 & 1794 \\
\hline SE & Pinhão & 6.084 & 155,888 & 38,32 & 1216,8 \\
\hline SE & Pirambu & 8.538 & 205,879 & 40,65 & 1707,6 \\
\hline SE & Riachuelo & 9.509 & 78,938 & 118,51 & 1901,8 \\
\hline SE & Rosário do Catete & 9.541 & 105,660 & 87,27 & 1908,2 \\
\hline SE & Santa Rosa de Lima & 3.773 & 67,607 & 55,45 & 754,6 \\
\hline SE & Santana do São Francisco & 7.175 & 45,620 & 154,27 & 1435 \\
\hline SE & São Francisco & 3.524 & 83,854 & 40,46 & 704,8 \\
\hline SE & São Miguel do Aleixo & 3.736 & 144,089 & 25,66 & 747,2 \\
\hline SE & Siriri & 8.169 & 165,813 & 48,27 & 1633,8 \\
\hline SE & Telha & 3.006 & 49,027 & 60,31 & 601,2 \\
\hline
\end{tabular}




\section{APÊNDICE B - CONSOLIDAÇÃO DOS RESULTADOS}

\section{B.1 - Consolidação dos resultados para Alagoas}

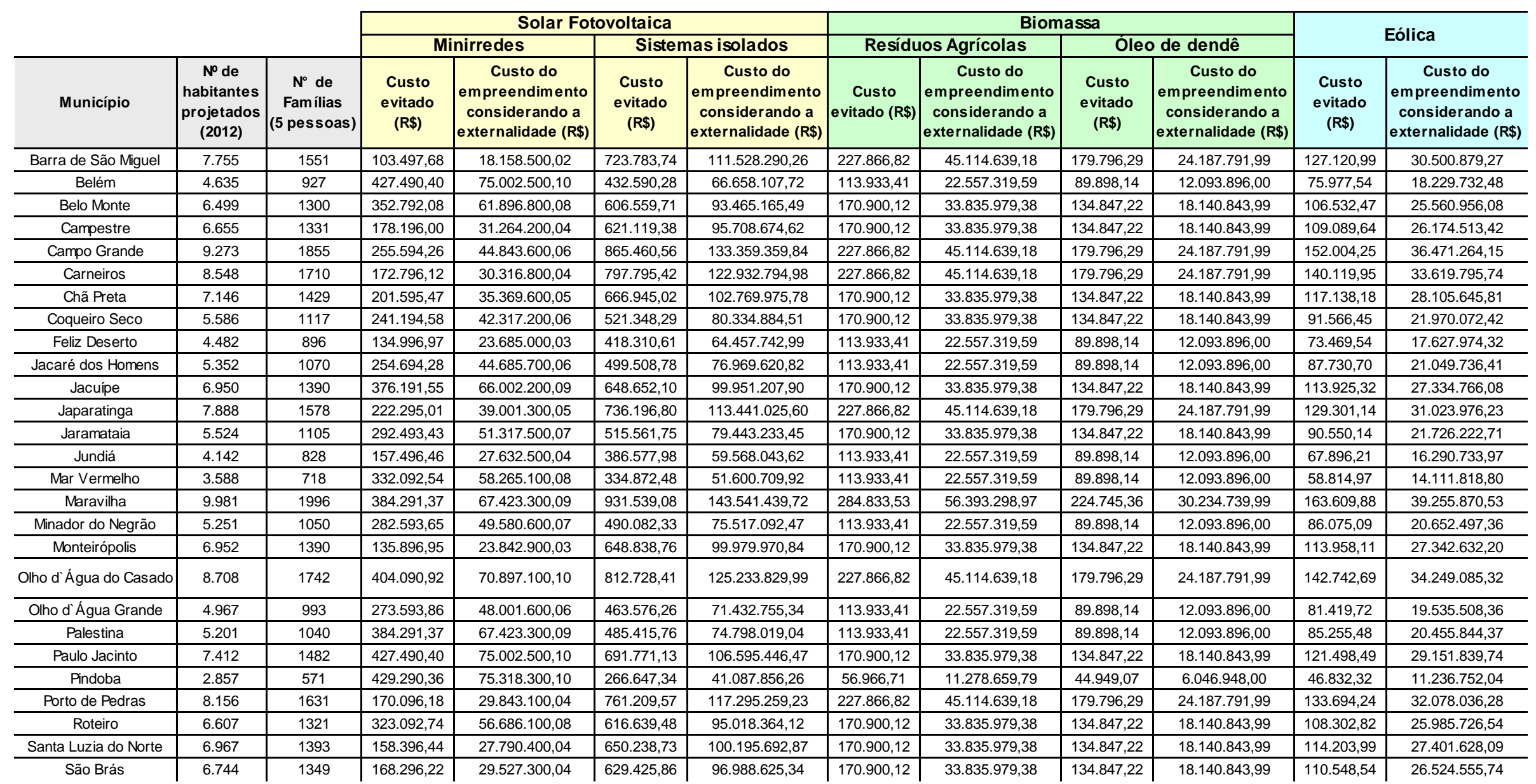




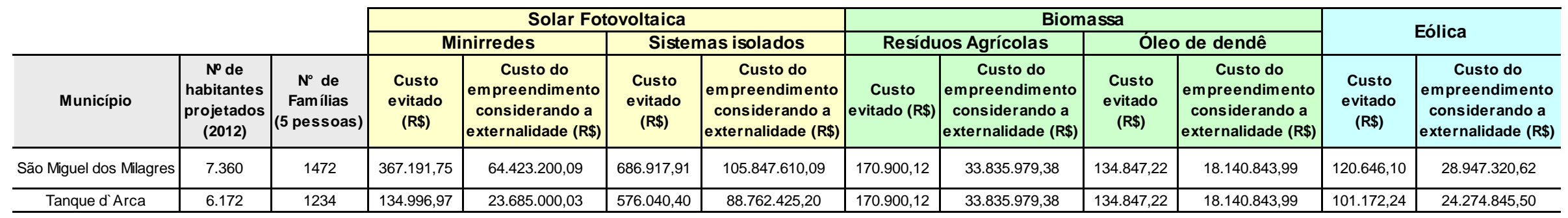


B.2 - Consolidação dos resultados para a Bahia

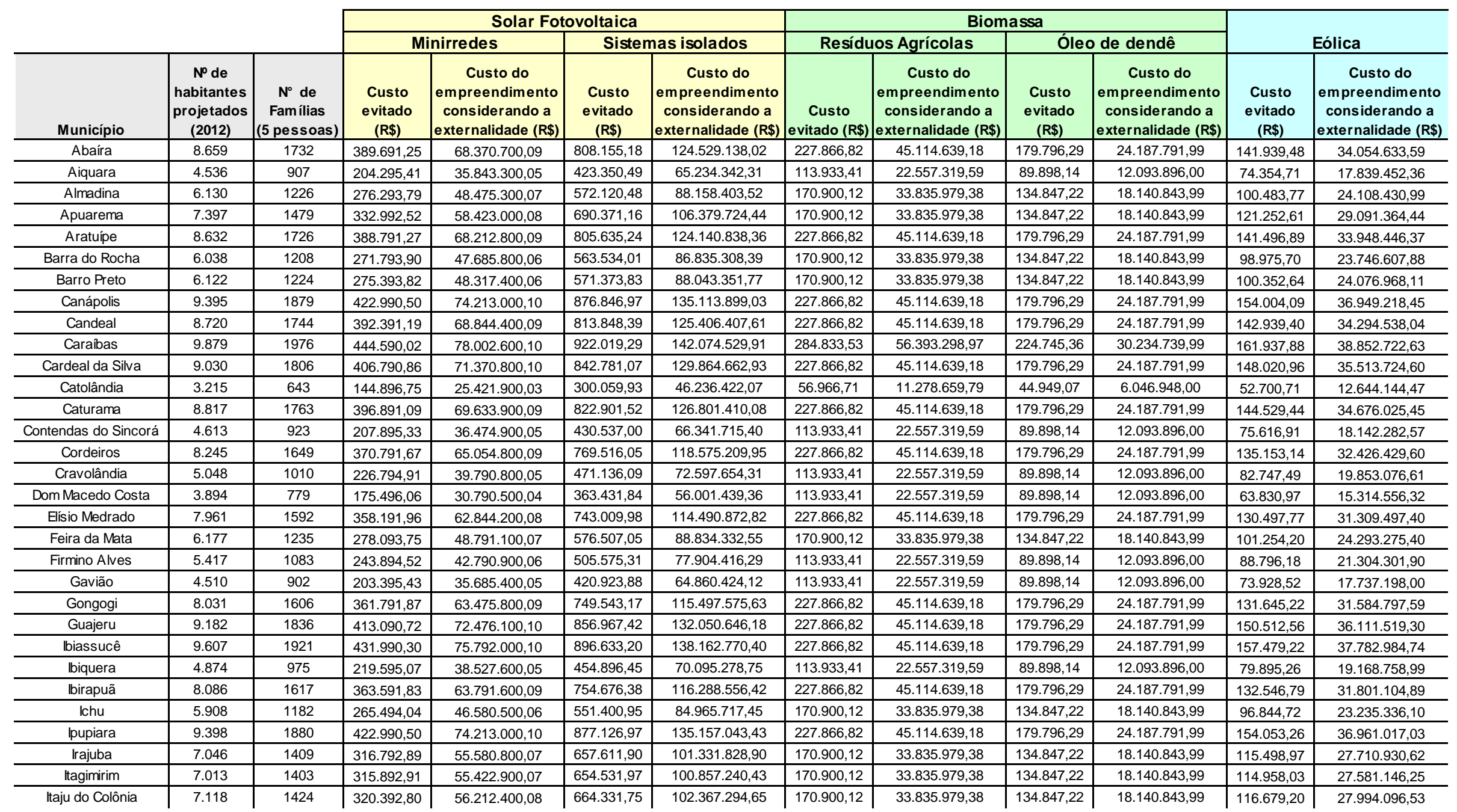




\begin{tabular}{|c|c|c|c|c|c|c|c|c|c|c|c|c|}
\hline & & & & & & & \multirow{2}{*}{\multicolumn{4}{|c|}{ Biomassa }} & \multirow{2}{*}{\multicolumn{2}{|c|}{ Eólica }} \\
\hline \multirow[b]{2}{*}{ Mun } & \multirow[b]{2}{*}{$\begin{array}{c}\text { NNo de } \\
\text { habitantes } \\
\text { projetados } \\
\text { (2012) }\end{array}$} & \multirow[b]{2}{*}{$\begin{array}{c}\mathrm{N}^{\circ} \text { de } \\
\text { Familias } \\
\text { (5 pessoas) }\end{array}$} & \multicolumn{4}{|c|}{ Solar Fotovoltaica } & & & & & & \\
\hline & & & $\begin{array}{l}\text { Custo } \\
\text { evitado } \\
\text { (RS) }\end{array}$ & \begin{tabular}{|c|} 
Custo do \\
empreendimento \\
considerando a \\
externalidade (RS)
\end{tabular} & $\begin{array}{l}\text { Custo } \\
\text { evitado } \\
\text { (R\$) }\end{array}$ & \begin{tabular}{|c|} 
Custo do \\
empreendimento \\
considerando a \\
externalidade (R\$)
\end{tabular} & $\begin{array}{c}\text { Custo } \\
\text { evitado (RS) }\end{array}$ & \begin{tabular}{|c|} 
Custo do \\
empreendimento \\
considerando a \\
externalidade (R\$)
\end{tabular} & $\begin{array}{l}\text { Custo } \\
\text { evitado } \\
\text { (R\$) }\end{array}$ & \begin{tabular}{|c|} 
Custo do \\
empreendimento \\
considerando a \\
externalidade (R\$)
\end{tabular} & $\begin{array}{l}\text { Custo } \\
\text { evitado } \\
\text { (R\$) }\end{array}$ & $\begin{array}{c}\text { Custo do } \\
\text { em preendimento } \\
\text { considerando a } \\
\text { externalidade (RS) }\end{array}$ \\
\hline Itamari & & & $352.792,08$ & $61.896 .800,08$ & $731.343,58$ & $112.693 .189,22$ & $227.866,82$ & $45.114 .639,18$ & $179.796,29$ & $24.187 .791,99$ & $128.448,75$ & $30.817 .889,92$ \\
\hline Itanagra & 7.590 & 1518 & $341.992,32$ & $60.002 .000,08$ & $708.384,09$ & $109.155 .347,91$ & \begin{tabular}{|l|l|}
$170.900,12$ \\
\end{tabular} & $33.835 .979,38$ & $134.847,22$ & $18.140 .843,99$ & $124.416,29$ & $29.850 .406,39$ \\
\hline Itaquara & 7.751 & 1550 & $349.192,16$ & $61.265 .200,08$ & $723.410,42$ & $111.470 .764,38$ & \begin{tabular}{|l|l|}
$227.866,82$ \\
\end{tabular} & $45.114 .639,18$ & $179.796,29$ & $24.187 .791,99$ & $127.055,42$ & $30.483 .596,83$ \\
\hline Jaborandi & 8.728 & 1746 & $392.391,19$ & $68.844 .400,09$ & $814.595,04$ & $125.521 .459,36$ & \begin{tabular}{|l|}
$227.866,82$ \\
\end{tabular} & $45.114 .639,18$ & $179.796,29$ & $24.187 .791,99$ & $143.070,54$ & $34.326 .000,92$ \\
\hline Jucuruçu & 9.972 & 1994 & $449.089,91$ & $78.792 .100,11$ & $930.699,10$ & $143.412 .006,50$ & \begin{tabular}{|l|}
$284.833,53$ \\
\end{tabular} & $56.393 .298,97$ & $224.745,36$ & $30.234 .739,99$ & $163.462,35$ & $39.218 .478,60$ \\
\hline Jussari & 6.322 & 1264 & $284.393,61$ & $49.896 .400,07$ & $590.040,08$ & $90.919 .645,52$ & \begin{tabular}{|l|l|}
$170.900,12$ \\
\end{tabular} & $33.835 .979,38$ & $134.847,22$ & $18.140 .843,99$ & $103.631,06$ & $24.863 .540,08$ \\
\hline Jussiape & 7.533 & 1507 & $339.292,38$ & $59.528 .300,08$ & $703.064,21$ & $108.335 .604,19$ & $170.900,12$ & $33.835 .979,38$ & $134.847,22$ & $18.140 .843,99$ & $123.481,94$ & $29.626 .233,38$ \\
\hline Lafaiete Coutinho & 3.830 & 766 & $172.796,12$ & $30.316 .800,04$ & $357.458,64$ & $55.081 .025,36$ & \begin{tabular}{|l|l|}
$113.933,41$ \\
\end{tabular} & $22.557 .319,59$ & $89.898,14$ & $12.093 .896,00$ & $62.781,87$ & $15.062 .853,29$ \\
\hline Lajedão & 3.782 & 756 & $170.096,18$ & $29.843 .100,04$ & $352.978,74$ & $54.390 .714,86$ & \begin{tabular}{|l|l|}
$113.933,41$ \\
\end{tabular} & $22.557 .319,59$ & $89.898,14$ & $12.093 .896,00$ & $61.995,05$ & 14.874.076,02 \\
\hline Lajedinho & 3.881 & 776 & $174.596,08$ & $30.632 .600,04$ & $362.218,53$ & $55.814 .480,27$ & \begin{tabular}{|l|l|}
$113.933,41$ \\
\end{tabular} & $22.557 .319,59$ & $89.898,14$ & $12.093 .896,00$ & $63.617,87$ & $15.263 .429,14$ \\
\hline Lajedo do Tabocal & 8.346 & 1669 & $375.291,57$ & $65.844 .300,09$ & $778.942,51$ & $120.027 .738,29$ & \begin{tabular}{|l|l|}
$227.866,82$ \\
\end{tabular} & $45.114 .639,18$ & $179.796,29$ & $24.187 .791,99$ & $136.808,74$ & $32.823 .648,45$ \\
\hline Lamarão & 9.271 & 1854 & $417.590,62$ & $73.265 .600,10$ & $865.273,90$ & $133.330 .596,90$ & $227.866,82$ & $45.114 .639,18$ & $179.796,29$ & $24.187 .791,99$ & $151.971,46$ & 36.4 \\
\hline Macururé & 7.992 & 1598 & $359.991,92$ & $63.160 .000,08$ & $745.903,25$ & $114.936 .698,35$ & \begin{tabular}{|l|}
$227.866,82$ \\
\end{tabular} & $45.114 .639,18$ & $179.796,29$ & $24.187 .791,99$ & $131.005,93$ & $31.431 .416,06$ \\
\hline Maetinga & 6.048 & 1210 & $271.793,90$ & $47.685 .800,06$ & $564.467,32$ & $86.979 .123,08$ & \begin{tabular}{|l|l|}
$170.900,12$ \\
\end{tabular} & $33.835 .979,38$ & $134.847,22$ & $18.140 .843,99$ & $99.139,62$ & $23.785 .936,48$ \\
\hline Maiquinique & 9.229 & & $414.890,68$ & 72.79 & $861.353,99$ & $132.726 .575,21$ & \begin{tabular}{|l|l|}
$227.866,82$ \\
\end{tabular} & $45.114 .639,18$ & $\begin{array}{l}179.796,29 \\
\end{array}$ & $24.187 .791,99$ & $151.282,99$ & 36.2 \\
\hline Malhada de Pedras & 8.389 & 1678 & $377.091,53$ & $66.160 .100,09$ & $782.955,75$ & $120.646 .141,45$ & \begin{tabular}{|l|l|}
$227.866,82$ \\
\end{tabular} & $45.114 .639,18$ & $\begin{array}{l}179.796,29 \\
\end{array}$ & $24.187 .791,99$ & $137.513,60$ & $32.992 .761,43$ \\
\hline Mirante & 9.902 & 1980 & $445.489,99$ & $78.160 .500,11$ & $924.165,91$ & $142.405 .303,69$ & \begin{tabular}{|l|l|}
$284.833,53$ \\
\end{tabular} & $56.393 .298,97$ & $224.745,36$ & $30.234 .739,99$ & $162.314,90$ & $38.943 .178,40$ \\
\hline Morpará & 8.233 & & $370.791,67$ & $65.054 .800,09$ & $768.396,08$ & $118.402 .632,32$ & \begin{tabular}{|l|l|}
$227.866,82$ \\
\end{tabular} & $45.114 .639,18$ & $\begin{array}{l}179.796,29 \\
\end{array}$ & $24.187 .791,99$ & $134.956,43$ & 32.379. \\
\hline Muniz Ferreira & 7.374 & 1475 & $332.092,54$ & $58.265 .100,08$ & $688.224,54$ & $106.048 .950,66$ & $170.900,12$ & $33.835 .979,38$ & $134.847,22$ & $18.140 .843,99$ & $120.875,59$ & $29.000 .908,66$ \\
\hline Nova Fátima & 7.630 & 1526 & $343.792,28$ & $60.317 .800,08$ & $712.117,34$ & $109.730 .606,66$ & \begin{tabular}{|l|l|}
$227.866,82$ \\
\end{tabular} & $45.114 .639,18$ & $\begin{array}{l}179.796,29 \\
\end{array}$ & $24.187 .791,99$ & $125.071,97$ & $30.007 .720,79$ \\
\hline Nova lbiá & 6.570 & 421 & $296.093,35$ & $51.949 .100,07$ & $613.186,23$ & & \begin{tabular}{|l|l|}
$170.900,12$ \\
\end{tabular} & $33.835 .979,38$ & $134.847,22$ & 43,99 & $107.696,31$ & $25.838 .889,33$ \\
\hline Nova Itarana & 7.563 & 1513 & $340.192,36$ & $59.686 .200,08$ & $705.864,15$ & $108.767 .048,25$ & \begin{tabular}{|l|l|}
$170.900,12$ \\
\end{tabular} & $33.835 .979,38$ & $\begin{array}{l}134.847,22 \\
\end{array}$ & $\begin{array}{ll}18.140 .843,99 \\
\end{array}$ & $123.973,70$ & $29.744 .219,18$ \\
\hline Nova Redenção & 8.053 & 1611 & $362.691,85$ & $63.633 .700,09$ & $751.596,45$ & $115.813 .967,95$ & \begin{tabular}{|l|l|}
$227.866,82$ \\
\end{tabular} & $45.114 .639,18$ & $\begin{array}{l}179.796,29 \\
\end{array}$ & $24.187 .791,99$ & $132.005,85$ & $31.671 .320,51$ \\
\hline Ouriçangas & 8.316 & 1663 & $374.391,59$ & $65.686 .400,09$ & $776.142,57$ & $119.596 .294,23$ & \begin{tabular}{|l|}
$227.866,82$ \\
\end{tabular} & $45.114 .639,18$ & $179.796,29$ & $24.187 .791,99$ & $136.316,98$ & $32.705 .662,66$ \\
\hline Palmeiras & 8.545 & 1709 & $384.291,37$ & $67.423 .300,09$ & $797.515,42$ & 122.889.650,58 & \begin{tabular}{|l|}
$227.866,82$ \\
\end{tabular} & $45.114 .639,18$ & $179.796,29$ & $24.187 .791,99$ & $140.070,78$ & $33.606 .287,56$ \\
\hline Pedrão & 6.993 & 1399 & $314.992,93$ & $55.265 .000,07$ & $652.665,34$ & $100.569 .611,06$ & \begin{tabular}{|l|}
$170.900,12$ \\
\end{tabular} & $33.835 .979,38$ & $134.847,22$ & $18.140 .843,99$ & $114.630,19$ & $27.502 .489,05$ \\
\hline Piraí do Norte & 9.833 & 1967 & $\begin{array}{l}442.790,06 \\
\end{array}$ & $77.686 .800,10$ & $917.726,06$ & $141.412 .982,34$ & \begin{tabular}{|l|}
$284.833,53$ \\
\end{tabular} & $56.393 .298,97$ & $224.745,36$ & $30.234 .739,99$ & $161.183,84$ & $38.671 .811,07$ \\
\hline Planaltino & 8.944 & 178 & $402.290,97$ & $70.581 .300,09$ & $834.754,59$ & 20 & \begin{tabular}{|l|l|}
$227.866,82$ \\
\end{tabular} & 639,18 & $179.796,29$ & $24.187 .791,99$ & $146.611,24$ & $35.175 .498,65$ \\
\hline Potiraguá & 9.360 & 1872 & 421.190,54 & $73.897 .200,10$ & $873.580,38$ & $134.610 .547,62$ & $227.866,82$ & $45.114 .639,18$ & $\begin{array}{l}179.796,29 \\
\end{array}$ & $24.187 .791,99$ & $153.430,36$ & $36.811 .568,36$ \\
\hline Quixabeira & 9.514 & 1903 & $428.390,38$ & $75.160 .400,10$ & $887.953,39$ & $136.825 .293,81$ & \begin{tabular}{|l|}
$227.866,82$ \\
\end{tabular} & $45.114 .639,18$ & $179.796,29$ & $24.187 .791,99$ & $155.954,75$ & $37.417 .228,78$ \\
\hline Rodelas & 8.045 & 1609 & $1.791,87$ & 0,09 & $750.849,80$ & 6,20 & $227.866,82$ & 639,18 & $179.796,29$ &, 99 & 13 & 7,63 \\
\hline Santa Cruz da Vitória & 6.481 & 1296 & $291.593,45$ & $51.159 .600,07$ & $604.879,75$ & $93.206 .299,05$ & \begin{tabular}{|l|}
$170.900,12$ \\
\end{tabular} & $33.835 .979,38$ & $\begin{array}{l}134.847,22 \\
\end{array}$ & $18.140 .843,99$ & $106.237,41$ & $25.488 .864,80$ \\
\hline Santa Teresinha & 9.792 & 1958 & $440.990,10$ & $77.371 .000,10$ & $913.899,48$ & $140.823 .342,12$ & $284.833,53$ & $56.393 .298,97$ & $224.745,36$ & $30.234 .739,99$ & $160.511,77$ & $38.510 .563,82$ \\
\hline & 8.835 & 11 & & & & & 6,82 & & & & & \\
\hline São Domingos & 9.266 & 1853 & $416.690,64$ & $73.107 .700,10$ & $864.807,24$ & $133.258 .689,56$ & $227.866,82$ & $45.114 .639,18$ & $179.796,29$ & $24.187 .791,99$ & $151.889,50$ & $36.441 .879,53$ \\
\hline
\end{tabular}




\begin{tabular}{|c|c|c|c|c|c|c|c|c|c|c|c|c|}
\hline \multirow[b]{3}{*}{ Município } & \multirow[b]{3}{*}{$\begin{array}{c}\text { № de } \\
\text { habitantes } \\
\text { projetados } \\
\text { (2012) }\end{array}$} & \multirow[b]{3}{*}{$\begin{array}{c}N^{\circ} \text { de } \\
\text { Fam ílias } \\
(5 \text { pessoas })\end{array}$} & \multicolumn{4}{|c|}{ Solar Fotovoltaica } & \multicolumn{4}{|c|}{ Biomassa } & \multirow{2}{*}{\multicolumn{2}{|c|}{ Eólica }} \\
\hline & & & \multicolumn{2}{|c|}{ Minirredes } & \multicolumn{2}{|c|}{ Sistemas isolados } & \multicolumn{2}{|c|}{ Resíduos Agrícolas } & \multicolumn{2}{|c|}{ Óleo de dendê } & & \\
\hline & & & $\begin{array}{l}\text { Custo } \\
\text { evitado } \\
\text { (R\$) }\end{array}$ & $\begin{array}{c}\text { Custo do } \\
\text { empreendimento } \\
\text { considerando a } \\
\text { externalidade (R\$) }\end{array}$ & $\begin{array}{l}\text { Custo } \\
\text { evitado } \\
\text { (R\$) }\end{array}$ & \begin{tabular}{|c|} 
Custo do \\
empreendimento \\
considerando a \\
externalidade (R)
\end{tabular} & \begin{tabular}{|c|} 
Custo \\
evitado (R\$)
\end{tabular} & $\begin{array}{c}\text { Custo do } \\
\text { empreendimento } \\
\text { considerando a } \\
\text { externalidade (R\$) }\end{array}$ & $\begin{array}{l}\text { Custo } \\
\text { evitado } \\
\text { (R\$) }\end{array}$ & \begin{tabular}{|c|} 
Custo do \\
empreendimento \\
considerando a \\
externalidade (R\$)
\end{tabular} & $\begin{array}{l}\text { Custo } \\
\text { evitado } \\
\text { (R\$) }\end{array}$ & \begin{tabular}{|c|} 
Custo do \\
empreendimento \\
considerando a \\
externalidade (R\$)
\end{tabular} \\
\hline ão José da Vitória & 09 & & $251.994,34$ & $4.212 .000,06$ & $23.494,91$ & $0.665 .658,29$ & $170.900,12$ & $33.835 .979,38$ & $134.847,22$ & $18.140 .843,99$ & 91. & $22.059 .410,99$ \\
\hline Tanquinho & 35 & 57 & $361.791,87$ & $.475 .800,09$ & $749.916,49$ & $15.555 .101,51$ & $227.866,82$ & $45.114 .639,18$ & $179.796,29$ & $24.187 .791,99$ & $131.710,79$ & $31.600 .529,03$ \\
\hline Teodoro Sampaio & 46 & 49 & $348.292,18$ & $.107 .300,08$ & $722.943,76$ & $11.398 .857,04$ & $227.866,82$ & $45.114 .639,18$ & $179.796,29$ & $24.187 .791,99$ & $126.973,46$ & $30.463 .932,53$ \\
\hline Várzea do Poço & 59 & 2 & $394.191,15$ & $160.200,09$ & $817.488,31$ & $25.967 .284,89$ & $227.866,82$ & $45.114 .639,18$ & $179.796,29$ & $24.187 .791,99$ & $143.578,69$ & $34.447 .919,58$ \\
\hline Varzedo & 8.987 & 1797 & $404.090,92$ & $70.897 .100,10$ & $838.767,83$ & $129.246 .259,77$ & $227.866,82$ & $45.114 .639,18$ & $179.796,29$ & $24.187 .791,99$ & $147.316,10$ & $35.344 .611,63$ \\
\hline Vereda & 6.681 & 1336 & $300.593,25$ & $52.738 .600,07$ & $623.546,00$ & $96.082 .592,80$ & $170.900,12$ & $33.835 .979,38$ & $134.847,22$ & $18.140 .843,99$ & $109.515,84$ & $26.275 .436,77$ \\
\hline Wagner & 8.985 & 1797 & $404.090,92$ & $70.897 .100,10$ & $838.581,17$ & $129.217 .496,83$ & $227.866,82$ & $45.114 .639,18$ & $179.796,29$ & $24.187 .791,99$ & $147.283,31$ & $35.336 .745,91$ \\
\hline
\end{tabular}




\section{B.3 - Consolidação dos resultados para o Ceará}

\begin{tabular}{|c|c|c|c|c|c|c|c|c|c|c|c|c|}
\hline & \multirow{2}{*}{\multicolumn{4}{|c|}{ Solar Fotovoltaica }} & & & & & & \\
\hline & & & & & & & \multicolumn{4}{|c|}{ Biomassa } & \multicolumn{2}{|r|}{ Eólica } \\
\hline Município & \begin{tabular}{|c|} 
№ de \\
habitantes \\
projetados \\
$(2012)$ \\
\end{tabular} & $\begin{array}{c}\mathrm{N}^{\circ} \text { de } \\
\text { Famílias } \\
\text { (5 pessoas) }\end{array}$ & $\begin{array}{l}\text { Custo } \\
\text { evitado } \\
\text { (R\$) }\end{array}$ & \begin{tabular}{|c|} 
Custo do \\
empreendimento \\
considerando a \\
externalidade ( $R \$$ )
\end{tabular} & $\begin{array}{l}\text { Custo } \\
\text { evitado } \\
\text { (R\$) }\end{array}$ & \begin{tabular}{|c|} 
Custo do \\
empreendimento \\
considerando a \\
externalidade (R\$)
\end{tabular} & $\begin{array}{c}\text { Custo } \\
\text { evitado (R\$) }\end{array}$ & $\begin{array}{c}\text { Custo do } \\
\text { empreendimento } \\
\text { considerando a } \\
\text { externalidade ( } R \text { \$) }\end{array}$ & $\begin{array}{l}\text { Custo } \\
\text { evitado } \\
\text { (R\$) }\end{array}$ & \begin{tabular}{|c|} 
Custo do \\
empreendimento \\
considerando a \\
externalidade ( $(\mathrm{S} \$$
\end{tabular} & $\begin{array}{c}\text { Custo } \\
\text { evitado } \\
\text { (R\$) }\end{array}$ & $\begin{array}{c}\text { Custo do } \\
\text { empreendimento } \\
\text { considerando a } \\
\text { externalidade ( } R \$ \text { ) }\end{array}$ \\
\hline Altaneira & 7.033 & 1407 & $316.792,89$ & $55.580 .800,07$ & $656.398,59$ & $101.144 .869,81$ & \begin{tabular}{|l|}
$170.900,12$ \\
\end{tabular} & $33.835 .979,38$ & $134.847,22$ & $18.140 .843,99$ & $115.285,87$ & $27.659 .803,45$ \\
\hline Antonina do Norte & 7.056 & 1411 & $317.692,87$ & $55.738 .700,07$ & $658.545,21$ & $101.475 .643,59$ & $170.900,12$ & $33.835 .979,38$ & $134.847,22$ & $18.140 .843,99$ & $115.662,89$ & $27.750 .259,22$ \\
\hline Arneiroz & 567 & 1533 & $344.692,26$ & $.475 .700,08$ & $715.570,60$ & $0.262 .721,00$ & $227.866,82$ & $45.114 .639,18$ & $179.796,29$ & $24.187 .791,99$ & $125.678,48$ & $30.153 .236,60$ \\
\hline Baixio & 772 & 14 & $273.593,86$ & $3.001 .600,06$ & $566.707,27$ & $.324 .278,33$ & $170.900,12$ & $33.835 .979,38$ & $134.847,22$ & $18.140 .843,99$ & $99.533,03$ & $3.880 .325,11$ \\
\hline $\begin{array}{c}\text { Deputado Irapuan } \\
\text { Pinheiro } \\
\end{array}$ & 9.203 & 1841 & $413.990,70$ & $72.634 .000,10$ & $858.927,38$ & $132.352 .657,02$ & $227.866,82$ & $45.114 .639,18$ & $179.796,29$ & 24.187.791,99 & $150.856,80$ & $36.194 .109,36$ \\
\hline Ererê & 22 & 1384 & $311.393,01$ & $633.400,07$ & $646.038,82$ & $.548 .526,78$ & $170.900,12$ & $33.835 .979,38$ & $134.847,22$ & $18.140 .843,99$ & $113.466,34$ & $27.223 .256,00$ \\
\hline General Sampaio & 23 & 1285 & $288.893,51$ & $50.685 .900,07$ & $599.466,54$ & $2.372 .173,86$ & $170.900,12$ & $33.835 .979,38$ & $134.847,22$ & $18.140 .843,99$ & $105.286,67$ & $25.260 .758,93$ \\
\hline Granjeiro & 551 & 910 & $205.195,39$ & $36.001 .200,05$ & $424.750,46$ & $65.450 .064,34$ & $113.933,41$ & $22.557 .319,59$ & $89.898,14$ & $12.093 .896,00$ & $74.600,60$ & $17.898 .445,26$ \\
\hline Guaramiranga & 3.956 & 791 & $178.196,00$ & $31.264 .200,04$ & $369.218,37$ & $56.893 .090,43$ & $113.933,41$ & $22.557 .319,59$ & $89.898,14$ & $12.093 .896,00$ & $64.847,28$ & $15.558 .393,63$ \\
\hline Itaiçaba & 7.428 & 1486 & $333.892,50$ & $58.580 .900,08$ & $693.264,43$ & $106.825 .549,97$ & $170.900,12$ & $33.835 .979,38$ & $134.847,22$ & $18.140 .843,99$ & $121.760,76$ & $29.213 .283,09$ \\
\hline Jati & 7.647 & 1529 & $343.792,28$ & $60.317 .800,08$ & $713.703,97$ & 109.975.091,63 & $227.866,82$ & $45.114 .639,18$ & $179.796,29$ & $24.187 .791,99$ & $125.350,64$ & $30.074 .579,40$ \\
\hline Moraújo & 8.225 & 1645 & $369.891,69$ & $64.896 .900,09$ & $767.649,43$ & $118.287 .580,57$ & $227.866,82$ & $45.114 .639,18$ & $179.796,29$ & $24.187 .791,99$ & $134.825,29$ & $32.347 .772,41$ \\
\hline Pacujá & 37 & 1207 & $271.793,90$ & $47.685 .800,06$ & $563.440,68$ & $86.820 .926,92$ & $170.900,12$ & $33.835 .979,38$ & $134.847,22$ & $18.140 .843,99$ & $98.959,31$ & $23.742 .675,02$ \\
\hline Palhano & 972 & 1794 & $404.090,92$ & $70.897 .100,10$ & $837.367,86$ & $129.030 .537,74$ & $227.866,82$ & $45.114 .639,18$ & $179.796,29$ & $24.187 .791,99$ & $147.070,22$ & $35.285 .618,73$ \\
\hline Penaforte & 483 & 1697 & $381.591,43$ & $66.949 .600,09$ & $791.728,89$ & 121.997.999,51 & $227.866,82$ & $45.114 .639,18$ & $179.796,29$ & $24.187 .791,99$ & $139.054,46$ & $33.362 .450,25$ \\
\hline Potiretama & & 36 & $278.093,75$ & $48.791 .100,07$ & $576.880,38$ & $88.891 .858,42$ & \begin{tabular}{|l|}
$170.900,12$ \\
\end{tabular} & $33.835 .979,38$ & $134.847,22$ & $18.140 .843,99$ & $101.319,77$ & $24.309 .006,84$ \\
\hline o João do Jaguaribe & & 58 & $350.092,14$ & $.423 .100,08$ & $726.863,68$ & $2.002 .878,72$ & \begin{tabular}{|l|}
$227.866,82$ \\
\end{tabular} & $45.114 .639,18$ & $179.796,29$ & $4.187 .791,99$ & $127.661,93$ & $30.629 .112,65$ \\
\hline Senador Sá & 7.041 & 1408 & $316.792,89$ & $55.580 .800,07$ & $657.145,24$ & $101.259 .921,56$ & \begin{tabular}{|l|}
$170.900,12$ \\
\end{tabular} & $33.835 .979,38$ & $134.847,22$ & $18.140 .843,99$ & $115.417,01$ & $27.691 .266,32$ \\
\hline Tarrafas & 8.865 & 1773 & $398.691,05$ & $69.949 .700,09$ & $827.381,42$ & $127.491 .720,58$ & $227.866,82$ & $45.114 .639,18$ & $179.796,29$ & $24.187 .791,99$ & $145.316,26$ & $34.864 .802,72$ \\
\hline Umari & 7.562 & 1512 & $340.192,36$ & $59.686 .200,08$ & $705.770,82$ & $108.752 .666,78$ & \begin{tabular}{|l|}
$170.900,12$ \\
\end{tabular} & $33.835 .979,38$ & $134.847,22$ & $18.140 .843,99$ & $123.957,31$ & $29.740 .286,32$ \\
\hline
\end{tabular}




\section{B.4 - Consolidação dos resultados para o Maranhão}

\begin{tabular}{|c|c|c|c|c|c|c|c|c|c|c|c|c|}
\hline \multirow[b]{3}{*}{ Município } & \multirow[b]{3}{*}{$\begin{array}{c}\text { № de } \\
\text { habitantes } \\
\text { projetados } \\
(2012)\end{array}$} & \multirow[b]{3}{*}{$\begin{array}{c}N^{\circ} \text { de } \\
\text { Famílias } \\
(5 \text { pessoas })\end{array}$} & \multicolumn{4}{|c|}{ Solar Fotovoltaica } & \multicolumn{4}{|c|}{ Biomassa } & \multirow{2}{*}{\multicolumn{2}{|c|}{ Eólica }} \\
\hline & & & \multicolumn{2}{|c|}{ Minirredes } & \multicolumn{2}{|c|}{ Sistemas isolados } & \multicolumn{2}{|c|}{ Resíduos Agrícolas } & \multicolumn{2}{|c|}{ Óleo de dendê } & & \\
\hline & & & $\begin{array}{l}\text { Custo } \\
\text { evitado } \\
\text { (R\$) }\end{array}$ & \begin{tabular}{|c|} 
Custo do \\
empreendimento \\
considerando a \\
externalidade (R\$)
\end{tabular} & $\begin{array}{c}\text { Custo } \\
\text { evitado } \\
\text { (R\$) }\end{array}$ & \begin{tabular}{|c|} 
Custo do \\
empreendimento \\
considerando a \\
externalidade $(R \$)$
\end{tabular} & $\begin{array}{c}\text { Custo } \\
\text { evitado }(R \$)\end{array}$ & \begin{tabular}{|c|} 
Custo do \\
empreendimento \\
considerando a \\
externalidade (R\$)
\end{tabular} & $\begin{array}{l}\text { Custo } \\
\text { evitado } \\
\text { (R\$) }\end{array}$ & \begin{tabular}{|c|} 
Custo do \\
empreendimento \\
considerando a \\
externalidade (R\$)
\end{tabular} & $\begin{array}{l}\text { Custo } \\
\text { evitado } \\
\text { (R\$) }\end{array}$ & $\begin{array}{c}\text { Custo do } \\
\text { empreendimento } \\
\text { considerando a } \\
\text { externalidade (R\$) }\end{array}$ \\
\hline Afonso Cunha & 6.090 & 1218 & $274.493,84$ & $48.159 .500,06$ & $568.387,23$ & $87.583 .144,77$ & $170.900,12$ & $33.835 .979,38$ & $134.847,22$ & $18.140 .843,99$ & $99.828,09$ & $23.951 .116,59$ \\
\hline Amapá do Maranhão & 583 & 17 & $6.093,35$ & $1.949 .100,07$ & $614.399,53$ & $94.673 .208,87$ & $170.900,12$ & $33.835 .979,38$ & $134.847,22$ & $18.140 .843,99$ & $107.909,41$ & 6,51 \\
\hline Bacurituba & 5.387 & 1077 & $42.094,56$ & $42.475 .100,06$ & $502.775,38$ & $77.472 .972,22$ & $113.933,41$ & $22.557 .319,59$ & $89.898,14$ & $12.093 .896,00$ & $88.304,42$ & $1.186 .316,10$ \\
\hline Belágua & 6.986 & 1397 & $314.092,95$ & $55.107 .100,07$ & $652.012,02$ & $100.468 .940,78$ & $170.900,12$ & $33.835 .979,38$ & $134.847,22$ & $18.140 .843,99$ & $114.515,44$ & $7.474 .959,03$ \\
\hline Benedito Leite & 5.497 & 1099 & $247.494,44$ & $43.422 .500,06$ & $513.041,81$ & 79.054.933,79 & $170.900,12$ & $33.835 .979,38$ & $134.847,22$ & $18.140 .843,99$ & $90.107,55$ & $21.618 .930,69$ \\
\hline Bernardo do Mearim & 6.111 & 1222 & $275.393,82$ & 48.317.400,06 & $570.347,19$ & $87.885 .155,61$ & $170.900,12$ & $33.835 .979,38$ & $134.847,22$ & $18.140 .843,99$ & $100.172,32$ & $24.033 .706,65$ \\
\hline Boa Vista do Gurupi & 375 & 675 & $377.091,53$ & $66.160 .100,09$ & $781.649,11$ & $120.444 .800,89$ & $227.866,82$ & $45.114 .639,18$ & $179.796,29$ & $24.187 .791,99$ & $137.284,11$ & $32.937 .701,39$ \\
\hline Brejo de Areia & 62 & 2 & $3.194,99$ & $159.200,05$ & $463.109,60$ & $71.360 .848,00$ & $113.933,41$ & $22.557 .319,59$ & $89.898,14$ & $12.093 .896,00$ & $81.337,76$ & 550,66 \\
\hline Cachoeira Grande & 07 & 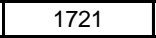 & $6.991,31$ & $897.000,09$ & $803.301,96$ & 123.781.301,64 & $227.866,82$ & $45.114 .639,18$ & $179.796,29$ & $24.187 .791,99$ & $141.087,09$ & $0.124,88$ \\
\hline Central do Maranhão & & & $365.391,79$ & 0,09 & $757.849,65$ & 6,35 & $227.866,82$ & 639,18 & $179.796,29$ & 24.1 & 133.1 & 2,12 \\
\hline $\begin{array}{l}\text { Feira Nova do } \\
\text { Maranhão }\end{array}$ & 8.215 & 1643 & 36 & 0,09 & $766.716,11$ & 5,89 & 6,82 & 39,18 & 6,29 & 91,99 & $134.661,37$ & 32.308 .443$, \\
\hline Fernando Falcão & 84 & 17 & $1.090,32$ & $75.634 .100,10$ & $894.486,58$ & $137.831 .996,62$ & $227.866,82$ & $45.114 .639,18$ & $179.796,29$ & $24.187 .791,99$ & $157.102,20$ & $37.692 .528,97$ \\
\hline Governador Luiz Rocha & 462 & 1492 & 692,46 & $58.896 .700,08$ & $696.437,69$ & 107.314.519,91 & $0.900,12$ & $33.835 .979,38$ & $4.847,22$ & $18.140 .843,99$ & $122.318,10$ & $.000,33$ \\
\hline Graça Aranh & & & $7.193,77$ & 633.2 & 87,11 & 32,89 & $0.900,12$ & $.835 .979,38$ & $4.847,22$ & 3,99 & 1,62 & 8,18 \\
\hline Jatobá & 51 & 310 & $7.690,84$ & $71.528 .700,10$ & $844.741,03$ & $130.166 .673,77$ & $27.866,82$ & $45.114 .639,18$ & $179.796,29$ & $24.187 .791,99$ & $148.365,19$ & $5.596 .314,66$ \\
\hline Junco do Maranhão & 3.792 & 758 & $170.996,16$ & $30.001 .000,04$ & $353.912,05$ & $54.534 .529,55$ & $113.933,41$ & $22.557 .319,59$ & $89.898,14$ & $12.093 .896,00$ & $62.158,97$ & $14.913 .404,62$ \\
\hline Lago dos Rodrigues & 7.744 & 1549 & $348.292,18$ & $1.107 .300,08$ & $722.757,10$ & $111.370 .094,10$ & $227.866,82$ & $45.114 .639,18$ & $179.796,29$ & $24.187 .791,99$ & $126.940,68$ & $30.456 .066,81$ \\
\hline eado Novo & 06 & 21 & $319.492,82$ & $56.054 .500,08$ & $663.211,77$ & $102.194 .717,03$ & $170.900,12$ & $33.835 .979,38$ & $134.847,22$ & $18.140 .843,99$ & $116.482,50$ & $27.946 .902,22$ \\
\hline ues & & & 31 &, 07 & 92,77 & 95.3 & $170.900,12$ & $33.835 .979,38$ & $134.847,22$ & 3,99 & & \\
\hline Marajá do Sena & & & $9.192,16$ & $265.200,08$ & $723.410,42$ & $111.470 .764,38$ & $227.866,82$ & $45.114 .639,18$ & $179.796,29$ & 24.187.791,99 & $127.055,42$ & $33.596,83$ \\
\hline Milagres do Maranhão & & & $8.991,71$ & $.739 .000,09$ & $764.849,49$ & $117.856 .136,51$ & $227.866,82$ & $0.114 .639,18$ & $179.796,29$ & $24.187 .791,99$ & $134.333,53$ & $2.229 .786,61$ \\
\hline Montes Altos & 72 & 54 & $417.590,62$ & $.265 .600,10$ & $865.367,23$ & 133.344.978,37 & $227.866,82$ & $45.114 .639,18$ & $179.796,29$ & $24.187 .791,99$ & $151.987,86$ & $36.465 .476,69$ \\
\hline Nova Colinas & 5.034 & 007 & $226.794,91$ & $39.790 .800,05$ & $469.829,45$ & $72.396 .313,75$ & $113.933,41$ & $22.557 .319,59$ & $89.898,14$ & $12.093 .896,00$ & $82.518,00$ & 19.798.016,57 \\
\hline Nova lorque & 4.598 & 920 & $206.995,35$ & $36.317 .000,05$ & $429.137,03$ & $66.125 .993,37$ & $113.933,41$ & $22.557 .319,59$ & $89.898,14$ & $12.093 .896,00$ & $75.371,03$ & $18.083 .289,67$ \\
\hline Porto Rico do Maranhão & 5.978 & 1196 & $269.093,96$ & $47.212 .100,06$ & $557.934,14$ & $85.972 .420,26$ & $170.900,12$ & $33.835 .979,38$ & $134.847,22$ & $18.140 .843,99$ & $97.992,17$ & $23.510 .636,29$ \\
\hline Presidente Médici & 4 & & $295.193,37$ & $791.200,07$ & $612.626,24$ & 94.399.960,96 & $170.900,12$ & $33.835 .979,38$ & $134.847,22$ & $18.140 .843,99$ & $107.597,96$ & $25.815 .292,17$ \\
\hline Ribamar Fiquene & 444 & 89 & $334.792,48$ & $3.738 .800,08$ & $694.757,73$ & $107.055 .653,47$ & $170.900,12$ & $33.835 .979,38$ & $134.847,22$ & $18.140 .843,99$ & $122.023,04$ & $29.276 .208,85$ \\
\hline Sambaiba & 5.522 & 1104 & $248.394,42$ & $43.580 .400,06$ & $515.375,09$ & $79.414 .470,51$ & $170.900,12$ & $33.835 .979,38$ & $134.847,22$ & $18.140 .843,99$ & $90.517,36$ & $21.717 .252,19$ \\
\hline $\begin{array}{l}\text { Santa Filomena do } \\
\text { Maranhão }\end{array}$ & 7.246 & 1449 & $5.792,68$ & $57.159 .800,08$ & $6.278,15$ & 104.208.122,65 & $0.900,12$ & $3.835 .979,38$ & $134.847,22$ & $18.140 .843,99$ & $118.777,39$ & 0.49 .50 \\
\hline
\end{tabular}




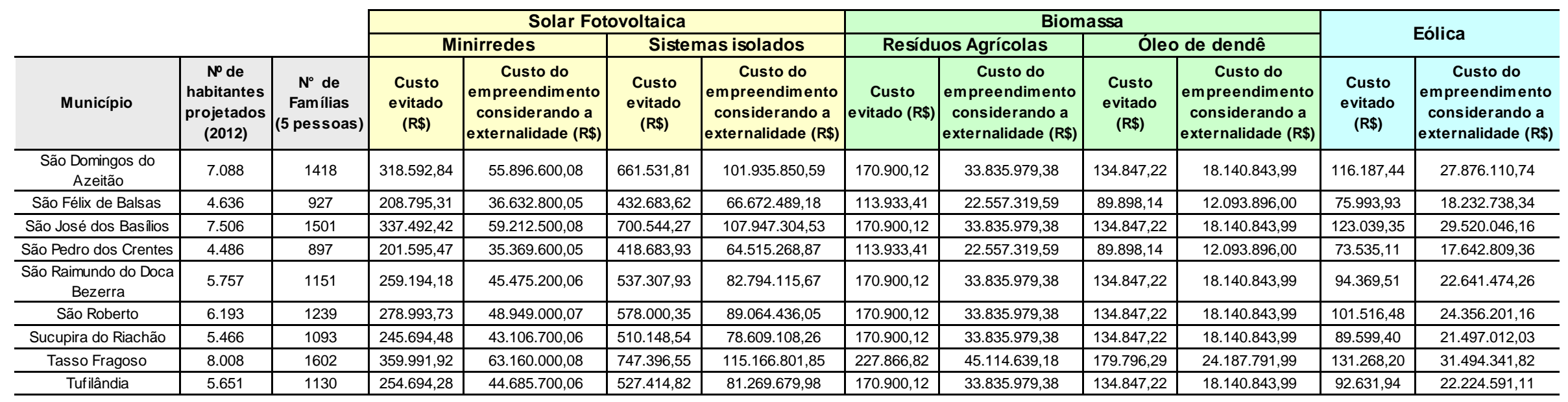




\section{B.5 - Consolidação dos resultados para a Paraíba}

\begin{tabular}{|c|c|c|c|c|c|c|c|c|c|c|c|c|}
\hline \multirow[b]{3}{*}{ Município } & \multirow[b]{3}{*}{\begin{tabular}{|c|}
\multicolumn{1}{c}{$N o$ de } \\
habitantes \\
projetados \\
$(2012)$
\end{tabular}} & \multirow[b]{3}{*}{$\begin{array}{c}\mathrm{N}^{\circ} \text { de } \\
\text { Fam ílias } \\
\text { (5 pessoas) }\end{array}$} & \multicolumn{4}{|c|}{ Solar Fotovoltaica } & \multicolumn{4}{|c|}{ Biomassa } & \multirow{2}{*}{\multicolumn{2}{|c|}{ Eólica }} \\
\hline & & & \multicolumn{2}{|c|}{ Minirredes } & \multicolumn{2}{|c|}{ Sistemas isolados } & \multicolumn{2}{|c|}{ Resíduos Agrícolas } & \multicolumn{2}{|c|}{ Óleo de dendê } & & \\
\hline & & & $\begin{array}{l}\text { Custo } \\
\text { evitado } \\
\text { (R\$) }\end{array}$ & $\begin{array}{c}\text { Custo do } \\
\text { empreendimento } \\
\text { considerando a } \\
\text { externalidade (R\$) }\end{array}$ & $\begin{array}{l}\text { Custo } \\
\text { evitado } \\
\text { (R\$) }\end{array}$ & $\begin{array}{c}\text { Custo do } \\
\text { empreendimento } \\
\text { considerando a } \\
\text { externalidade (R\$) }\end{array}$ & $\begin{array}{c}\text { Custo } \\
\text { evitado (R\$) }\end{array}$ & $\begin{array}{c}\text { Custo do } \\
\text { empreendimento } \\
\text { considerando a } \\
\text { externalidade (R\$) }\end{array}$ & $\begin{array}{c}\text { Custo } \\
\text { evitado } \\
\text { (R\$) }\end{array}$ & $\begin{array}{c}\text { Custo do } \\
\text { empreendimento } \\
\text { considerando a } \\
\text { externalidade (R\$) }\end{array}$ & $\begin{array}{c}\text { Custo } \\
\text { evitado } \\
\text { (R\$) }\end{array}$ & $\begin{array}{c}\text { Custo do } \\
\text { empreendimento } \\
\text { considerando a } \\
\text { externalidade (R\$) }\end{array}$ \\
\hline Água Branca & 9.611 & 1922 & $432.890,28$ & $75.949 .900,10$ & \begin{tabular}{|l|}
$897.006,52$ \\
\end{tabular} & $138.220 .296,28$ & $\begin{array}{ll}7.866,82 \\
\end{array}$ & $45.114 .639,18$ & $179.796,29$ & $24.187 .791,99$ & $157.544,79$ & $37.798 .716,18$ \\
\hline Aguiar & 514 & 1103 & $48.394,42$ & $43.580 .400,06$ & \begin{tabular}{|l|}
$514.628,44$ \\
\end{tabular} & $79.299 .418,76$ & $170.900,12$ & $33.835 .979,38$ & \begin{tabular}{|l|}
$134.847,22$ \\
\end{tabular} & $18.140 .843,99$ & $90.386,22$ & $21.685 .789,31$ \\
\hline Alcantil & 282 & 1056 & $37.594,66$ & $41.685 .600,06$ & $92.975,60$ & $75.962 .918,00$ & $113.933,41$ & $22.557 .319,59$ & $89.898,14$ & $12.093 .896,00$ & $86.583,25$ & $20.773 .365,82$ \\
\hline Algodão de Jandaíra & 2.390 & 478 & $107.997,57$ & $18.948 .000,03$ & $223.061,66$ & $34.371 .710,34$ & $56.966,71$ & $11.278 .659,79$ & $44.949,07$ & $6.046 .948,00$ & $39.177,20$ & $9.399 .535,08$ \\
\hline Amparo & 2.119 & 424 & \begin{tabular}{|l|}
$95.397,86$ \\
\end{tabular} & $16.737 .400,02$ & \begin{tabular}{|l|}
$197.768,89$ \\
\end{tabular} & $30.474 .332,31$ & $56.966,71$ & $11.278 .659,79$ & $44.949,07$ & $6.046 .948,00$ & $34.734,93$ & $8.333 .730,06$ \\
\hline Aparecida & 7.832 & 1566 & $352.792,08$ & $61.896 .800,08$ & $730.970,25$ & $112.635 .663,35$ & $227.866,82$ & $45.114 .639,18$ & $179.796,29$ & $24.187 .791,99$ & $128.383,18$ & $30.802 .158,48$ \\
\hline Areia de Baraúnas & 01 & 380 & $85.498,08$ & $15.000 .500,02$ & $177.422,68$ & $27.339 .172,12$ & $56.966,71$ & $11.278 .659,79$ & $44.949,07$ & $6.046 .948,00$ & $31.161,44$ & $7.476 .366,61$ \\
\hline Assunção & 07 & 721 & $161.996,36$ & $3.422 .000,04$ & $336.645,77$ & $51.873 .957,83$ & $113.933,41$ & $22.557 .319,59$ & $89.898,14$ & $12.093 .896,00$ & $59.126,42$ & $14.185 .825,54$ \\
\hline Baía da Traiçãc & 43 & 1649 & $0.791,67$ & $.054 .800,09$ & $769.329,39$ & $18.546 .447,01$ & $227.866,82$ & $14.639,18$ & $179.796,29$ & $187.791,99$ & $135.120,35$ & 63,88 \\
\hline Baraúna & 879 & 876 & $7.095,57$ & $4.580 .100,05$ & \begin{tabular}{|l|}
$408.697,49$ \\
\end{tabular} & $62.976 .451,71$ & $113.933,41$ & $2.557 .319,59$ & $89.898,14$ & $2.093 .896,00$ & $71.781,15$ & $17.221 .993,36$ \\
\hline Barra de Santana & 191 & 1638 & \begin{tabular}{|l|}
$368.991,71$ \\
\end{tabular} & $64.739 .000,09$ & \begin{tabular}{|l|}
$764.476,16$ \\
\end{tabular} & $117.798 .610,64$ & \begin{tabular}{|l|}
$227.866,82$ \\
\end{tabular} & $45.114 .639,18$ & \begin{tabular}{|l|}
$179.796,29$ \\
\end{tabular} & $24.187 .791,99$ & \begin{tabular}{|l|}
$134.267,96$ \\
\end{tabular} & $32.214 .055,17$ \\
\hline Barra de São Miguel & 5.679 & 1136 & $255.594,26$ & $44.843 .600,06$ & $530.028,10$ & $81.672 .361,10$ & $170.900,12$ & $33.835 .979,38$ & $134.847,22$ & $18.140 .843,99$ & $93.090,92$ & $22.334 .711,19$ \\
\hline Belém do Brejo do Cruz & 7.163 & 1433 & $322.192,76$ & $56.528 .200,08$ & $668.531,65$ & $103.014 .460,75$ & $170.900,12$ & $33.835 .979,38$ & $134.847,22$ & $18.140 .843,99$ & $117.416,85$ & $28.171 .075,23$ \\
\hline Bernardino Batista & 3.153 & 631 & $142.196,81$ & $24.948 .200,03$ & $294.273,39$ & $45.344 .771,01$ & $56.966,71$ & $11.278 .659,79$ & $44.949,07$ & $6.046 .948,00$ & $51.684,39$ & $12.400 .307,16$ \\
\hline Boa Ventura & 5.625 & 1125 & $252.894,32$ & $44.369 .900,06$ & $524.988,21$ & $80.895 .761,79$ & $170.900,12$ & $33.835 .979,38$ & $134.847,22$ & $18.140 .843,99$ & $92.205,75$ & $22.122 .336,75$ \\
\hline Boa Vista & 6.415 & 1283 & $288.893,51$ & $50.685 .900,07$ & $598.719,89$ & $92.257 .122,11$ & $170.900,12$ & $33.835 .979,38$ & $134.847,22$ & $18.140 .843,99$ & $105.155,53$ & $25.229 .296,05$ \\
\hline Bom Jesus & 32 & 486 & $109.797,53$ & $19.263 .800,03$ & $226.981,57$ & $34.975 .732,03$ & $56.966,71$ & $11.278 .659,79$ & $44.949,07$ & $6.046 .948,00$ & $39.865,67$ & $9.564 .715,20$ \\
\hline Bom Sucesso & 98 & 1000 & $24.994,95$ & $9.475 .000,05$ & \begin{tabular}{|l|}
$466.469,52$ \\
\end{tabular} & $1.878 .580,88$ & $13.933,41$ & $22.557 .319,59$ & $89.898,14$ & $12.093 .896,00$ & $81.927,88$ & 19.656 .4 \\
\hline Borborema & 69 & 1034 & $232.194,79$ & $40.738 .200,05$ & $482.429,17$ & $74.337 .812,03$ & $113.933,41$ & $22.557 .319,59$ & $89.898,14$ & $12.093 .896,00$ & $84.730,93$ & $20.328 .952,65$ \\
\hline Brejo dos Santos & 6.236 & 1247 & $280.793,69$ & $49.264 .800,07$ & $582.013,60$ & $89.682 .839,20$ & $170.900,12$ & $33.835 .979,38$ & $134.847,22$ & $18.140 .843,99$ & $102.221,34$ & $24.525 .314,13$ \\
\hline Cabaceiras & 5.148 & 1030 & $231.294,81$ & $40.580 .300,05$ & $480.469,21$ & $74.035 .801,19$ & $113.933,41$ & $22.557 .319,59$ & $89.898,14$ & $12.093 .896,00$ & $84.386,70$ & $20.246 .362,60$ \\
\hline Cachoeira dos índios & 9.685 & 1937 & $435.590,22$ & $76.423 .600,10$ & $903.913,03$ & $139.284 .524,97$ & $227.866,82$ & $45.114 .639,18$ & $179.796,29$ & $24.187 .791,99$ & $158.757,81$ & $38.089 .747,81$ \\
\hline Cacimba de Areia & 3.590 & 718 & $161.996,36$ & $28.422 .000,04$ & $335.059,14$ & $51.629 .472,86$ & $113.933,41$ & $22.557 .319,59$ & $89.898,14$ & $12.093 .896,00$ & $58.847,76$ & $14.118 .966,92$ \\
\hline Cacimbas & 6.877 & 1375 & $309.593,05$ & $54.317 .600,07$ & \begin{tabular}{|l|l}
$641.838,92$ \\
\end{tabular} & $98.901 .360,68$ & $170.900,12$ & $33.835 .979,38$ & $134.847,22$ & $18.140 .843,99$ & $112.728,70$ & $27.046 .277,31$ \\
\hline Caiçara & 7.205 & 1441 & $323.992,72$ & $56.844 .000,08$ & \begin{tabular}{|l}
$672.451,56$ \\
\end{tabular} & $103.618 .482,44$ & $170.900,12$ & $33.835 .979,38$ & $134.847,22$ & $18.140 .843,99$ & $118.105,32$ & $28.336 .255,34$ \\
\hline Cajazeirinhas & 3.061 & 612 & $137.696,91$ & $24.158 .700,03$ & $285.686,92$ & $44.021 .675,88$ & $56.966,71$ & $11.278 .659,79$ & $44.949,07$ & $6.046 .948,00$ & $50.176,32$ & $12.038 .484,05$ \\
\hline Caldas Brandão & 5.710 & 1142 & $257.394,22$ & $45.159 .400,06$ & $532.921,36$ & $82.118 .186,64$ & $170.900,12$ & $33.835 .979,38$ & $134.847,22$ & $18.140 .843,99$ & $93.599,08$ & $22.456 .629,84$ \\
\hline Camalaú & 793 & 1159 & $260.994,14$ & $45.791 .000,06$ & $540.667,86$ & $3.311 .848,54$ & $170.900,12$ & $33.835 .979,38$ & $134.847,22$ & $18.140 .843,99$ & $94.959,63$ & $22.783 .057,21$ \\
\hline pim & & & \begin{tabular}{|l}
$261.894,12$ \\
\end{tabular} & $948.900,06$ & $2.814,48$ & $.642 .622,32$ & $170.900,12$ & $33.835 .979,38$ & \begin{tabular}{|l|}
$134.847,22$ \\
\end{tabular} & $18.140 .843,99$ & $95.336,64$ & $22.873 .512,99$ \\
\hline Caraúbas & & 790 & $178.196,00$ & $264.200,04$ & \begin{tabular}{|l|}
$368.751,72$ \\
\end{tabular} & $56.821 .183,08$ & $113.933,41$ & $22.557 .319,59$ & $89.898,14$ & $12.093 .896,00$ & $64.765,32$ & $15.538 .729,34$ \\
\hline & 2.441 & 488 & $.797,53$ & 800,03 & $227.821,55$ & $35.105 .165,25$ & $56.966,71$ & $11.278 .659,79$ & $44.949,07$ & $6.046 .948,00$ & $40.013,20$ & $9.600 .110,94$ \\
\hline
\end{tabular}




\begin{tabular}{|c|c|c|c|c|c|c|c|c|c|c|c|c|}
\hline \multirow[b]{3}{*}{ Município } & \multirow[b]{3}{*}{$\begin{array}{c}\text { № de } \\
\text { habitantes } \\
\text { projetados } \\
\text { (2012) }\end{array}$} & \multirow[b]{3}{*}{$\begin{array}{c}N^{\circ} \text { de } \\
\text { Famílias } \\
(5 \text { pessoas })\end{array}$} & \multicolumn{4}{|c|}{ Solar Fotovoltaica } & \multicolumn{4}{|c|}{ Biomassa } & \multirow{2}{*}{\multicolumn{2}{|c|}{ Eólica }} \\
\hline & & & \multicolumn{2}{|c|}{ Minirredes } & \multicolumn{2}{|c|}{ Sistemas isolados } & \multicolumn{2}{|c|}{ Resíduos Agrícolas } & \multicolumn{2}{|c|}{ Óleo de dendê } & & \\
\hline & & & $\begin{array}{l}\text { Custo } \\
\text { evitado } \\
\text { (R\$) }\end{array}$ & \begin{tabular}{|c|} 
Custo do \\
empreendimento \\
considerando a \\
externalidade $(R \$)$
\end{tabular} & $\begin{array}{c}\text { Custo } \\
\text { evitado } \\
\text { (R\$) }\end{array}$ & $\begin{array}{c}\text { Custo do } \\
\text { empreendimento } \\
\text { considerando a } \\
\text { externalidade (R\$) }\end{array}$ & $\begin{array}{c}\text { Custo } \\
\text { evitado ( } R \$)\end{array}$ & $\begin{array}{c}\text { Custo do } \\
\text { empreendimento } \\
\text { considerando a } \\
\text { externalidade (R\$) }\end{array}$ & $\begin{array}{l}\text { Custo } \\
\text { evitado } \\
\text { (R\$) }\end{array}$ & $\begin{array}{c}\text { Custo do } \\
\text { empreendimento } \\
\text { considerando a } \\
\text { externalidade (R\$) }\end{array}$ & $\begin{array}{l}\text { Custo } \\
\text { evitado } \\
\text { (R\$) }\end{array}$ & $\begin{array}{c}\text { Custo do } \\
\text { empreendimento } \\
\text { considerando a } \\
\text { externalidade (R\$) }\end{array}$ \\
\hline Casserengue & 7.132 & 1426 & $321.292,78$ & $56.370 .300,08$ & $665.638,38$ & 102.568.635,22 & $170.900,12$ & $33.835 .979,38$ & $134.847,22$ & $18.140 .843,99$ & $116.908,69$ & $28.049 .156,57$ \\
\hline Catingueira & 4.822 & 964 & $216.895,13$ & $38.053 .900,05$ & $450.043,23$ & $69.347 .442,37$ & $113.933,41$ & $22.557 .319,59$ & $89.898,14$ & $12.093 .896,00$ & $79.042,86$ & $18.964 .250,28$ \\
\hline Caturité & 4.598 & 920 & $206.995,35$ & $36.317 .000,05$ & $429.137,03$ & $66.125 .993,37$ & $113.933,41$ & $22.557 .319,59$ & $89.898,14$ & $12.093 .896,00$ & $75.371,03$ & 18.083.289,67 \\
\hline Condado & 6.598 & 1320 & $296.993,33$ & $52.107 .000,07$ & $615.799,50$ & $94.888 .930,90$ & $170.900,12$ & $33.835 .979,38$ & $134.847,22$ & $18.140 .843,99$ & $108.155,29$ & $25.949 .009,40$ \\
\hline Congo & 4.692 & 938 & $211.495,25$ & $37.106 .500,05$ & $437.910,17$ & $67.477 .851,43$ & $113.933,41$ & $22.557 .319,59$ & $89.898,14$ & $12.093 .896,00$ & $76.911,89$ & $18.452 .978,50$ \\
\hline Coxixola & 1.802 & 360 & $80.998,18$ & $14.211 .000,02$ & $168.182,89$ & $25.915 .406,71$ & $56.966,71$ & $11.278 .659,79$ & $44.949,07$ & $6.046 .948,00$ & $29.538,62$ & $7.087 .013,48$ \\
\hline Cubati & 6.939 & 1388 & $312.292,99$ & $54.791 .300,07$ & $647.625,46$ & $99.793 .011,74$ & $170.900,12$ & $33.835 .979,38$ & $134.847,22$ & $18.140 .843,99$ & $113.745,01$ & $27.290 .114,62$ \\
\hline Cuité de Mamanguape & 6.214 & 1243 & $279.893,71$ & $49.106 .900,07$ & $579.960,31$ & $89.366 .446,89$ & $170.900,12$ & $33.835 .979,38$ & $134.847,22$ & $18.140 .843,99$ & $101.860,71$ & $24.438 .791,21$ \\
\hline Cuitegi & 6.834 & 1367 & $307.793,09$ & $54.001 .800,07$ & $637.825,68$ & $98.282 .957,52$ & $170.900,12$ & $33.835 .979,38$ & $134.847,22$ & $18.140 .843,99$ & $112.023,84$ & $26.877 .164,33$ \\
\hline Curral de Cima & 5.192 & 1038 & $233.994,74$ & $41.054 .000,06$ & $484.575,78$ & $74.668 .585,82$ & $113.933,41$ & $22.557 .319,59$ & $89.898,14$ & $12.093 .896,00$ & $85.107,95$ & $20.419 .408,43$ \\
\hline Curral Velho & 2.497 & 499 & $112.497,47$ & $19.737 .500,03$ & $233.048,10$ & $35.910 .527,50$ & $56.966,71$ & $11.278 .659,79$ & $44.949,07$ & $6.046 .948,00$ & $40.931,16$ & $9.820 .351,09$ \\
\hline Damião & 4.990 & 998 & $224.994,95$ & $39.475 .000,05$ & $465.722,87$ & $71.763 .529,13$ & $113.933,41$ & $22.557 .319,59$ & $89.898,14$ & $12.093 .896,00$ & $81.796,74$ & $19.624 .970,74$ \\
\hline Desterro & 8.035 & 1607 & $361.791,87$ & $63.475 .800,09$ & $749.916,49$ & $115.555 .101,51$ & $227.866,82$ & $45.114 .639,18$ & $\begin{array}{l}179.796,29 \\
\end{array}$ & $24.187 .791,99$ & $131.710,79$ & $31.600 .529,03$ \\
\hline Diamante & 6.571 & 1314 & $296.093,35$ & $51.949 .100,07$ & $613.279,56$ & $94.500 .631,24$ & $170.900,12$ & $33.835 .979,38$ & $134.847,22$ & $18.140 .843,99$ & $107.712,71$ & $25.842 .822,19$ \\
\hline Duas Estradas & 3.611 & 722 & $162.896,34$ & $28.579 .900,04$ & $337.019,10$ & $51.931 .483,70$ & $113.933,41$ & $22.557 .319,59$ & $89.898,14$ & $12.093 .896,00$ & $59.191,99$ & $14.201 .556,98$ \\
\hline Emas & 3.356 & 671 & $151.196,60$ & $26.527 .200,04$ & $313.219,63$ & $48.264 .209,17$ & $113.933,41$ & $22.557 .319,59$ & $89.898,14$ & $12.093 .896,00$ & $55.012,00$ & $13.198 .677,71$ \\
\hline Frei Martinho & 2.935 & 587 & $132.297,03$ & $23.211 .300,03$ & $273.927,18$ & $42.209 .610,82$ & $56.966,71$ & $11.278 .659,79$ & $44.949,07$ & $6.046 .948,00$ & $48.110,91$ & $11.542 .943,71$ \\
\hline Gado Bravo & 8.355 & 1671 & $376.191,55$ & $66.002 .200,09$ & $779.782,49$ & $120.157 .171,51$ & $227.866,82$ & $45.114 .639,18$ & $179.796,29$ & $24.187 .791,99$ & $136.956,27$ & $32.859 .044,19$ \\
\hline Gurjão & 3.215 & 643 & $144.896,75$ & $25.421 .900,03$ & $300.059,93$ & $46.236 .422,07$ & $56.966,71$ & $11.278 .659,79$ & $44.949,07$ & $6.046 .948,00$ & $52.700,71$ & $12.644 .144,47$ \\
\hline lbiara & 5.978 & 1196 & $269.093,96$ & $47.212 .100,06$ & $557.934,14$ & $85.972 .420,26$ & $170.900,12$ & $33.835 .979,38$ & $134.847,22$ & $18.140 .843,99$ & $97.992,17$ & $23.510 .636,29$ \\
\hline Igaracy & 6.134 & 1227 & $276.293,79$ & $48.475 .300,07$ & $572.493,81$ & $88.215 .929,39$ & $170.900,12$ & $33.835 .979,38$ & $134.847,22$ & $18.140 .843,99$ & $100.549,34$ & $24.124 .162,43$ \\
\hline Jericó & 7.557 & 1511 & $340.192,36$ & $59.686 .200,08$ & $705.304,16$ & $108.680 .759,44$ & $170.900,12$ & $33.835 .979,38$ & $134.847,22$ & $18.140 .843,99$ & $123.875,35$ & $29.720 .622,02$ \\
\hline Juarez Távora & 7.550 & 1510 & $340.192,36$ & $59.686 .200,08$ & $704.650,84$ & $108.580 .089,16$ & $170.900,12$ & $33.835 .979,38$ & $134.847,22$ & $18.140 .843,99$ & $123.760,60$ & $29.693 .092,00$ \\
\hline Junco do Seridó & 6.745 & 1349 & $303.293,19$ & $53.212 .300,07$ & $629.519,20$ & $97.003 .006,80$ & $170.900,12$ & $33.835 .979,38$ & $134.847,22$ & $18.140 .843,99$ & $110.564,94$ & $26.527 .139,80$ \\
\hline Juru & 9.793 & 1959 & $440.990,10$ & $77.371 .000,10$ & $913.992,81$ & $140.837 .723,59$ & $284.833,53$ & $56.393 .298,97$ & $224.745,36$ & $30.234 .739,99$ & $160.528,16$ & $38.514 .496,68$ \\
\hline Lagoa & 4.657 & 931 & $209.695,29$ & $36.790 .700,05$ & $434.643,57$ & $66.974 .500,03$ & $113.933,41$ & 22.557.319,59 & $89.898,14$ & $12.093 .896,00$ & $76.338,16$ & $18.315 .328,40$ \\
\hline Lagoa de Dentro & 7.413 & 1483 & $333.892,50$ & $58.580 .900,08$ & $691.864,46$ & 106.609.827,94 & $170.900,12$ & $33.835 .979,38$ & $134.847,22$ & $18.140 .843,99$ & $121.514,88$ & $29.154 .290,20$ \\
\hline Lastro & 2.800 & 560 & $125.997,17$ & $22.106 .000,03$ & $261.327,46$ & $40.268 .112,54$ & $56.966,71$ & $11.278 .659,79$ & $44.949,07$ & $6.046 .948,00$ & $45.897,97$ & $11.012 .007,63$ \\
\hline Livramento & 7.189 & 1438 & $323.092,74$ & $56.686 .100,08$ & $670.958,26$ & 103.388.378,94 & $170.900,12$ & $33.835 .979,38$ & $134.847,22$ & $18.140 .843,99$ & $117.843,04$ & $28.273 .329,58$ \\
\hline Logradouro & 4.026 & 805 & $180.895,94$ & $31.737 .900,04$ & $375.751,56$ & $57.899 .793,24$ & $113.933,41$ & $22.557 .319,59$ & $89.898,14$ & $12.093 .896,00$ & $65.994,73$ & $15.833 .693,83$ \\
\hline Mãe d’Água & 3.999 & 800 & $179.995,96$ & $31.580 .000,04$ & $373.231,62$ & $57.511 .493,58$ & $113.933,41$ & $22.557 .319,59$ & $89.898,14$ & $12.093 .896,00$ & $65.552,14$ & $15.727 .506,61$ \\
\hline Malta & 5.602 & 1120 & $251.994,34$ & $44.212 .000,06$ & $522.841,59$ & $80.564 .988,01$ & $170.900,12$ & $33.835 .979,38$ & $134.847,22$ & $18.140 .843,99$ & $91.828,73$ & $22.031 .880,98$ \\
\hline Marcação & 7.822 & 1564 & $351.892,10$ & $61.738 .900,08$ & $730.036,94$ & $112.491 .848,66$ & $227.866,82$ & $45.114 .639,18$ & $179.796,29$ & $24.187 .791,99$ & $128.219,26$ & $30.762 .829,88$ \\
\hline Marizópolis & 6.257 & 1251 & $281.693,67$ & $49.422 .700,07$ & $583.973,55$ & $89.984 .850,05$ & $170.900,12$ & $33.835 .979,38$ & $134.847,22$ & $18.140 .843,99$ & $102.565,58$ & $24.607 .904,19$ \\
\hline Mataraca & 7.641 & 1528 & $343.792,28$ & $60.317 .800,08$ & $713.143,98$ & 109.888.802,82 & $227.866,82$ & $45.114 .639,18$ & $179.796,29$ & 24.187.791,99 & $125.252,29$ & $30.050 .982,24$ \\
\hline
\end{tabular}




\begin{tabular}{|c|c|c|c|c|c|c|c|c|c|c|c|c|}
\hline & & & \multirow{2}{*}{\multicolumn{4}{|c|}{ Solar Fotovoltaica }} & & & & & \multirow{3}{*}{\multicolumn{2}{|c|}{ Eólica }} \\
\hline & & & & & & & \multicolumn{4}{|c|}{ Biomassa } & & \\
\hline & & & \multicolumn{2}{|c|}{ Minirredes } & \multicolumn{2}{|c|}{ Sistemas isolados } & \multicolumn{2}{|c|}{ Resíduos Agrícolas } & \multicolumn{2}{|c|}{ Óleo de dendê } & & \\
\hline Município & $\begin{array}{c}\text { № de } \\
\text { habitantes } \\
\text { projetados } \\
(2012)\end{array}$ & $\begin{array}{c}N^{\circ} \text { de } \\
\text { Famílias } \\
\text { (5 pessoas) }\end{array}$ & $\begin{array}{l}\text { Custo } \\
\text { evitado } \\
\text { (R\$) }\end{array}$ & \begin{tabular}{|c|} 
Custo do \\
empreendimento \\
considerando a \\
externalidade ( $R \$$ )
\end{tabular} & $\begin{array}{l}\text { Custo } \\
\text { evitado } \\
\text { (R\$) }\end{array}$ & \begin{tabular}{|c|} 
Custo do \\
empreendimento \\
considerando a \\
externalidade ( $R \$$ )
\end{tabular} & $\begin{array}{c}\text { Custo } \\
\text { evitado }(R \$)\end{array}$ & \begin{tabular}{|c|} 
Custo do \\
empreendimento \\
considerando a \\
externalidade (R\$)
\end{tabular} & $\begin{array}{l}\text { Custo } \\
\text { evitado } \\
\text { (R\$) }\end{array}$ & \begin{tabular}{|c|} 
Custo do \\
empreendimento \\
considerando a \\
externalidade (R\$)
\end{tabular} & $\begin{array}{l}\text { Custo } \\
\text { evitado } \\
\text { (R\$) }\end{array}$ & $\begin{array}{c}\text { Custo do } \\
\text { empreendimento } \\
\text { considerando a } \\
\text { externalidade (R\$) }\end{array}$ \\
\hline Matinhas & 4.357 & 871 & $196.195,59$ & $34.422 .200,05$ & $406.644,20$ & $62.660 .059,40$ & \begin{tabular}{|l|}
$113.933,41$ \\
\end{tabular} & $22.557 .319,59$ & $89.898,14$ & $12.093 .896,00$ & $71.420,52$ & $17.135 .470,44$ \\
\hline Mato Grosso & 2.744 & 549 & $123.297,23$ & $21.632 .300,03$ & $256.100,92$ & $39.462 .750,28$ & $56.966,71$ & $11.278 .659,79$ & $44.949,07$ & $6.046 .948,00$ & $44.980,01$ & $10.791 .767,48$ \\
\hline Maturéia & 6.076 & 1215 & $273.593,86$ & $48.001 .600,06$ & $567.080,60$ & $87.381 .804,20$ & $170.900,12$ & $33.835 .979,38$ & $134.847,22$ & $18.140 .843,99$ & $99.598,60$ & $23.896 .056,55$ \\
\hline Montadas & 5.145 & 1029 & $231.294,81$ & $40.580 .300,05$ & $480.189,22$ & 73.992.656,78 & $113.933,41$ & $22.557 .319,59$ & $89.898,14$ & $12.093 .896,00$ & $84.337,52$ & $20.234 .564,02$ \\
\hline Monte Horebe & 4.568 & 914 & $205.195,39$ & $6.001 .200,05$ & $426.337,09$ & $65.694 .549,31$ & $113.933,41$ & $22.557 .319,59$ & $89.898,14$ & $12.093 .896,00$ & $74.879,26$ & $17.965 .303,87$ \\
\hline Mulungu & 542 & 1908 & $429.290,36$ & $318.300,10$ & $890.566,67$ & $137.227 .974,93$ & $227.866,82$ & $45.114 .639,18$ & \begin{tabular}{|l|}
$179.796,29$ \\
\end{tabular} & $24.187 .791,99$ & $156.413,73$ & $37.527 .348,85$ \\
\hline Nazarezinho & 252 & 1450 & $326.692,66$ & $7.317 .700,08$ & $676.838,13$ & 104.294.411,47 & \begin{tabular}{|l|}
$170.900,12$ \\
\end{tabular} & $33.835 .979,38$ & \begin{tabular}{|l|}
$134.847,22$ \\
\end{tabular} & $18.140 .843,99$ & $118.875,75$ & $28.521 .099,76$ \\
\hline Nova Olinda & 6.012 & 1202 & $270.893,92$ & $47.527 .900,06$ & $561.107,40$ & $86.461 .390,20$ & \begin{tabular}{|l|}
$170.900,12$ \\
\end{tabular} & $33.835 .979,38$ & \begin{tabular}{|l|}
$134.847,22$ \\
\end{tabular} & $18.140 .843,99$ & $98.549,50$ & $23.644 .353,52$ \\
\hline Nova Palmeira & 4.480 & 896 & $1.595,47$ & $35.369 .600,05$ & $418.123,94$ & $64.428 .980,06$ & $113.933,41$ & $22.557 .319,59$ & $89.898,14$ & $12.093 .896,00$ & $73.436,76$ & $7.619 .212,20$ \\
\hline Olho d’Água & 6.796 & 1359 & $5.993,13$ & $53.686 .000,07$ & $634.279,09$ & $97.736 .461,71$ & \begin{tabular}{|l|}
$170.900,12$ \\
\end{tabular} & $33.835 .979,38$ & \begin{tabular}{|l|}
$134.847,22$ \\
\end{tabular} & $18.140 .843,99$ & $111.400,93$ & 15,66 \\
\hline Olivedos & 3.693 & 739 & $166.496,26$ & $29.211 .500,04$ & $344.672,26$ & $53.110 .764,14$ & \begin{tabular}{|l|}
$113.933,41$ \\
\end{tabular} & $22.557 .319,59$ & $89.898,14$ & $12.093 .896,00$ & $60.536,15$ & $14.524 .051,49$ \\
\hline Ouro Velho & 2.944 & 589 & $132.297,03$ & $23.211 .300,03$ & $274.767,16$ & $42.339 .044,04$ & $56.966,71$ & $11.278 .659,79$ & $44.949,07$ & $6.046 .948,00$ & $48.258,44$ & $11.578 .339,45$ \\
\hline Parari & 1.816 & 363 & $81.898,16$ & $14.368 .900,02$ & $169.489,53$ & $26.116 .747,27$ & $56.966,71$ & $11.278 .659,79$ & $44.949,07$ & $6.046 .948,00$ & $29.768,11$ & $7.142 .073,52$ \\
\hline Passagem & 2.272 & 454 & $102.597,70$ & $18.000 .600,02$ & $212.048,57$ & $32.674 .697,03$ & $56.966,71$ & $11.278 .659,79$ & $44.949,07$ & $6.046 .948,00$ & $37.242,93$ & $8.935 .457,62$ \\
\hline Pedra Branca & 3.726 & 745 & $77.396,24$ & $29.369 .400,04$ & $347.752,19$ & $53.585 .352,61$ & $113.933,41$ & $22.557 .319,59$ & $89.898,14$ & $12.093 .896,00$ & $61.077,09$ & $14.653 .835,86$ \\
\hline Pedra Lavrada & 05 & 4 & $1.992,32$ & $.002 .000,08$ & $709.784,06$ & $109.371 .069,94$ & \begin{tabular}{|l|}
$170.900,12$ \\
\end{tabular} & $33.835 .979,38$ & \begin{tabular}{|l|}
$134.847,22$ \\
\end{tabular} & $18.140 .843,99$ & $124.662,17$ & $29.909 .399,29$ \\
\hline Pedro Régis & 5.824 & 65 & $1.894,12$ & $.948 .900,06$ & $543.561,13$ & $83.757 .674,07$ & \begin{tabular}{|l|}
$170.900,12$ \\
\end{tabular} & $33.835 .979,38$ & \begin{tabular}{|l|}
$134.847,22$ \\
\end{tabular} & $18.140 .843,99$ & $95.467,78$ & $2.904 .975,87$ \\
\hline Pilões & 6.854 & 1371 & $8.693,07$ & $4.159 .700,07$ & $639.692,30$ & $98.570 .586,90$ & \begin{tabular}{|l|}
$170.900,12$ \\
\end{tabular} & $33.835 .979,38$ & \begin{tabular}{|l|}
$134.847,22$ \\
\end{tabular} & $18.140 .843,99$ & $112.351,68$ & $26.955 .821,53$ \\
\hline Pilõezinhos & 5.114 & 1023 & $230.394,83$ & $40.422 .400,05$ & $477.295,95$ & $73.546 .831,25$ & \begin{tabular}{|l|}
$113.933,41$ \\
\end{tabular} & $22.557 .319,59$ & $89.898,14$ & $12.093 .896,00$ & $83.829,37$ & $20.112 .645,36$ \\
\hline Poço Dantas & 3.740 & 748 & $168.296,22$ & $29.527 .300,04$ & $349.058,83$ & $53.786 .693,17$ & \begin{tabular}{|l|}
$113.933,41$ \\
\end{tabular} & $22.557 .319,59$ & $89.898,14$ & $12.093 .896,00$ & $61.306,58$ & $14.708 .895,90$ \\
\hline Poço de José de Moura & 4.046 & 809 & $181.795,92$ & $31.895 .800,04$ & $377.618,19$ & $58.187 .422,61$ & $113.933,41$ & 22.557.319,59 & $89.898,14$ & $12.093 .896,00$ & $66.322,57$ & $15.912 .351,02$ \\
\hline Prata & 3.919 & 784 & $176.396,04$ & $30.948 .400,04$ & $365.765,12$ & $56.360 .976,08$ & $113.933,41$ & $22.557 .319,59$ & $89.898,14$ & $12.093 .896,00$ & $64.240,77$ & $15.412 .877,82$ \\
\hline Quixabá & 1.759 & 352 & $79.198,22$ & $13.895 .200,02$ & $164.169,65$ & $25.297 .003,55$ & $56.966,71$ & $11.278 .659,79$ & $44.949,07$ & $6.046 .948,00$ & $28.833,76$ & $6.917 .900,51$ \\
\hline Riachão & & 88 & $150.296,62$ & $26.369 .300,04$ & $311.539,67$ & $48.005 .342,73$ & $113.933,41$ & $22.557 .319,59$ & $89.898,14$ & $12.093 .896,00$ & $54.716,94$ & 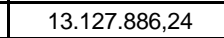 \\
\hline Riachão do Bacamarte & & 862 & $194.395,63$ & $.106 .400,05$ & $402.444,30$ & $62.012 .893,30$ & $113.933,41$ & $22.557 .319,59$ & $89.898,14$ & $12.093 .896,00$ & $70.682,88$ & $16.958 .491,75$ \\
\hline Riachão do Poço & 4.235 & 847 & $190.795,72$ & $33.474 .800,04$ & $395.257,79$ & $60.905 .520,21$ & $113.933,41$ & $22.557 .319,59$ & $89.898,14$ & $12.093 .896,00$ & $69.420,68$ & $16.655 .661,54$ \\
\hline $\begin{array}{c}\text { Riacho de Santo } \\
\text { Antônio }\end{array}$ & 1.781 & 356 & $80.098,20$ & $14.053 .100,02$ & $166.222,93$ & $25.613 .395,87$ & $56.966,71$ & $11.278 .659,79$ & $44.949,07$ & $6.046 .948,00$ & $29.194,39$ & $7.004 .423,42$ \\
\hline Riacho dos Cavalos & 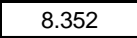 & 16 & $6.191,55$ & $002.200,09$ & $779.502,49$ & $120.114 .027,11$ & $227.866,82$ & $.114 .639,18$ & \begin{tabular}{|l|}
$179.796,29$ \\
\end{tabular} & $24.187 .791,99$ & $136.907,09$ & $32.847 .245,61$ \\
\hline Salgadinho & & 722 & $2.896,34$ & $.579 .900,04$ & $337.112,43$ & $51.945 .865,17$ & $113.933,41$ & $22.557 .319,59$ & $89.898,14$ & $12.093 .896,00$ & $59.208,38$ & $14.205 .489,84$ \\
\hline Santa Cruz & 71 & 294 & $291.593,45$ & $.159 .600,07$ & $603.946,44$ & $93.062 .484,36$ & $170.900,12$ & $33.835 .979,38$ & \begin{tabular}{|l|}
$134.847,22$ \\
\end{tabular} & $18.140 .843,99$ & $106.073,49$ & $25.449 .536,20$ \\
\hline Santa Helena & 5.886 & 1177 & $264.594,06$ & $46.422 .600,06$ & $549.347,66$ & $84.649 .325,14$ & $170.900,12$ & $33.835 .979,38$ & \begin{tabular}{|l|}
$134.847,22$ \\
\end{tabular} & $18.140 .843,99$ & $96.484,09$ & $23.148 .813,18$ \\
\hline Santa Inês & 3.538 & 708 & $159.296,42$ & $27.948 .300,04$ & $330.205,92$ & $50.881 .636,48$ & $113.933,41$ & $22.557 .319,59$ & $89.898,14$ & $12.093 .896,00$ & $57.995,37$ & $13.914 .458,21$ \\
\hline Santa Teresinha & 4.559 & 912 & $205.195,39$ & $36.001 .200,05$ & $425.497,11$ & $65.565 .116,09$ & $113.933,41$ & $22.557 .319,59$ & $89.898,14$ & $12.093 .896,00$ & $74.731,73$ & $17.929 .908,13$ \\
\hline Santana de Mangueira & 5.265 & 1053 & $236.694,68$ & $41.527 .700,06$ & $491.388,96$ & $75.718 .433,04$ & \begin{tabular}{ll|}
$113.933,41$ \\
\end{tabular} & $22.557 .319,59$ & $89.898,14$ & $12.093 .896,00$ & $86.304,58$ & $20.706 .507,20$ \\
\hline
\end{tabular}




\begin{tabular}{|c|c|c|c|c|c|c|c|c|c|c|c|c|}
\hline & & & & & & & \multirow{2}{*}{\multicolumn{4}{|c|}{\begin{tabular}{|c|c|}
\multicolumn{2}{c}{ Biomassa } \\
Resíduos Aarícolas & Oleo de dendê
\end{tabular}}} & & \\
\hline & Minirredes & \multicolumn{2}{|c|}{ Solar Fotovoltaica } & Sistemas isolados & & & & & \multicolumn{2}{|r|}{ Eólica } \\
\hline Municipio & \begin{tabular}{|c|} 
№ de \\
habitantes \\
projetados \\
(2012)
\end{tabular} & $\begin{array}{c}\mathrm{N}^{\circ} \text { de } \\
\text { Fam ílias } \\
\text { (5 pessoas) }\end{array}$ & $\begin{array}{l}\text { Custo } \\
\text { evitado } \\
\text { (R\$) }\end{array}$ & \begin{tabular}{|c|} 
Custo do \\
empreendimento \\
considerando a \\
externalidade (R\$)
\end{tabular} & $\begin{array}{l}\text { Custo } \\
\text { evitado } \\
\text { (R\$) }\end{array}$ & \begin{tabular}{|c|} 
Custo do \\
empreendimento \\
considerando a \\
externalidade ( $\mathrm{B} \$$
\end{tabular} & $\mid \begin{array}{c}\text { Custo } \\
\text { evitado (R\$) }\end{array}$ & \begin{tabular}{|c|} 
Custo do \\
empreendimento \\
considerando a \\
externalidade (RS)
\end{tabular} & $\begin{array}{c}\text { Custo } \\
\text { evitado } \\
\text { (R\$) }\end{array}$ & \begin{tabular}{|c|} 
Custo do \\
empreendimento \\
considerando a \\
externalidade (RS)
\end{tabular} & $\begin{array}{c}\text { Custo } \\
\text { evitado } \\
\text { (R\$) }\end{array}$ & $\begin{array}{c}\text { Custo do } \\
\text { empreendimento } \\
\text { considerando a } \\
\text { externalidade ( } \mathrm{R} \$ \text { ) }\end{array}$ \\
\hline Santana dos Garrotes & 7.173 & 1435 & \begin{tabular}{|l|l|}
$323.092,74$ \\
\end{tabular} & $56.686 .100,08$ & $669.464,96$ & $103.158 .275,44$ & \begin{tabular}{|l|}
$170.900,12$ \\
\end{tabular} & $33.835 .979,38$ & $134.847,22$ & $18.140 .843,99$ & $117.580,77$ & $28.210 .403,83$ \\
\hline Santo André & 2.545 & 509 & $114.297,43$ & $20.053 .300,03$ & $237.528,00$ & $36.600 .838,00$ & $56.966,71$ & $11.278 .659,79$ & \begin{tabular}{|l|l|}
$44.949,07$ \\
\end{tabular} & $6.046 .948,00$ & \begin{tabular}{|l|l|}
$41.717,98$ \\
\end{tabular} & $10.009 .128,36$ \\
\hline São Domingos do Cariri & 2.455 & 491 & $110.697,51$ & $19.421 .700,03$ & $229.128,19$ & $35.306 .505,81$ & $56.966,71$ & $11.278 .659,79$ & \begin{tabular}{ll|}
$44.949,07$ \\
\end{tabular} & $6.046 .948,00$ & $400.242,69$ & $9.655 .170,97$ \\
\hline São Francisco & 3.349 & 670 & $150.296,62$ & $26.369 .300,04$ & $312.566,31$ & $48.163 .538,89$ & \begin{tabular}{|l|}
$113.933,41$ \\
\end{tabular} & $22.557 .319,59$ & $89.898,14$ & $12.093 .896,00$ & $54.897,25$ & $13.171 .147,70$ \\
\hline São João do Cariri & 4.309 & 862 & $193.495,65$ & $33.948 .500,05$ & $402.164,30$ & $61.969 .748,90$ & \begin{tabular}{|l|}
$113.933,41$ \\
\end{tabular} & $22.557 .319,59$ & $89.898,14$ & $12.093 .896,00$ & $70.633,70$ & $16.946 .693,17$ \\
\hline São João do Tigre & 4.384 & 877 & \begin{tabular}{|l|l|}
$197.095,57$ \\
\end{tabular} & $34.580 .100,05$ & $409.164,14$ & $63.048 .359,06$ & $113.933,41$ & $22.557 .319,59$ & $89.898,14$ & $12.093 .896,00$ & $71.863,11$ & $17.241 .657,66$ \\
\hline São José da Lagoa & 7.560 & 1512 & $\mid 340.192,36$ & $59.686 .200,08$ & $705.584,15$ & 108.723.903,85 & $170.900,12$ & $33.835 .979,38$ & $134.847,22$ & $18.140 .843,99$ & $123.924,52$ & $29.732 .420,60$ \\
\hline São José de Caiana & 6.052 & 1210 & $272.693,88$ & $47.843 .700,06$ & $564.840,65$ & $87.036 .648,95$ & $170.900,12$ & $33.835 .979,38$ & $134.847,22$ & $18.140 .843,99$ & $99.205,19$ & $23.801 .667,92$ \\
\hline $\begin{array}{l}\text { São José de } \\
\text { Espinharas }\end{array}$ & 4.708 & 942 & $211.495,25$ & $37.106 .500,05$ & $439.403,46$ & $67.707 .954,94$ & $113.933,41$ & $22.557 .319,59$ & $89.898,14$ & $12.093 .896,00$ & $77.174,16$ & $18.515 .904,25$ \\
\hline São José de Princesa & 4.106 & 821 & $184.495,86$ & $32.369 .500,04$ & $383.218,06$ & $59.050 .310,74$ & \begin{tabular}{|l|}
$113.933,41$ \\
\end{tabular} & $22.557 .319,59$ & $89.898,14$ & $12.093 .896,00$ & $67.306,10$ & $16.148 .322,61$ \\
\hline São & 3.303 & 661 & $148.496,66$ & $26.053 .500,04$ & $308.273,08$ & $47.501 .991,32$ & $113.933,41$ & $22.557 .319,59$ & $89.898,14$ & $12.093 .896,00$ & $54.143,21$ & $12.990 .236,14$ \\
\hline $\begin{array}{l}\text { São José do Brejo do } \\
\text { Cruz }\end{array}$ & 1.707 & 341 & 76.498,28 & $13.421 .500,02$ & $159.316,42$ & $24.549 .167,18$ & $56.966,71$ & $11.278 .659,79$ & $44.949,07$ & $6.046 .948,00$ & $27.981,37$ & $6.713 .391,79$ \\
\hline São José do Sabugi & 4.027 & 805 & \begin{tabular}{|l|l|}
$180.895,94$ \\
\end{tabular} & $31.737 .900,04$ & $375.844,89$ & $57.914 .174,71$ & \begin{tabular}{|l|l|}
$113.933,41$ \\
\end{tabular} & $22.557 .319,59$ & \begin{tabular}{|l|l|}
$89.898,14$ \\
\end{tabular} & $12.093 .896,00$ & $66.011,12$ & $15.837 .626,68$ \\
\hline São José dos Cordeiros & 3.709 & 742 & $166.496,26$ & $29.211 .500,04$ & $346.165,56$ & $53.340 .867,64$ & $113.933,41$ & $22.557 .319,59$ & $89.898,14$ & $12.093 .896,00$ & $60.798,42$ & 14.586.977,25 \\
\hline amos & 5.600 & 1120 & 34 & $44.212 .000,06$ & $522.654,93$ & $80.536 .225,07$ & \begin{tabular}{|l|}
$170.900,12$ \\
\end{tabular} & 979,38 & 134.847,22 & $18.140 .843,99$ & $1.795,94$ & $22.024 .015,26$ \\
\hline São Mamede & 7.708 & & $346.492,22$ & $60.791 .500,08$ & $719.397,18$ & $110.852 .361,22$ & \begin{tabular}{|l|}
$227.866,82$ \\
\end{tabular} & $45.114 .639,18$ & $179.796,29$ & $24.187 .791,99$ & $126.350,56$ & 33,86 \\
\hline São Miguel de Taipu & 6.789 & 1358 & $305.093,15$ & $53.528 .100,07$ & $633.625,77$ & $97.635 .791,43$ & \begin{tabular}{|l|}
$170.900,12$ \\
\end{tabular} & $33.835 .979,38$ & 134.847,22 & $18.140 .843,99$ & \begin{tabular}{|l|}
$111.286,19$ \\
\end{tabular} & $26.700 .185,64$ \\
\hline $\begin{array}{l}\text { São Sebastião do } \\
\text { Umbuzeiro }\end{array}$ & 3.287 & 657 & \begin{tabular}{|l|l|}
$147.596,69$ \\
\end{tabular} & $25.895 .600,03$ & $306.779,78$ & $47.271 .887,82$ & \begin{tabular}{|l|l|}
$113.933,41$ \\
\end{tabular} & 22.557.319,59 & $89.898,14$ & $12.093 .896,00$ & $53.880,94$ & $12.927 .310,38$ \\
\hline Serra da R & & & & & & & & & & & & \\
\hline Serra Grande & & & 7 & $.000,03$ & $279.433,72$ & $3.117,48$ & \begin{tabular}{|l|}
$56.966,71$ \\
\end{tabular} & $11.278 .659,79$ & $\begin{array}{l}44.949,07 \\
\end{array}$ & $6.046 .948,00$ & $499.078,05$ & $11.774 .982,44$ \\
\hline Serra Redonda & & & & & & & \begin{tabular}{|l|}
$170.900,12$ \\
\end{tabular} & & & & & $27.577 .213,39$ \\
\hline Serraria & & & 093,75 & & $.320,39$ & 9,61 & $170.900,12$ & & 7,22 & 3,99 & \begin{tabular}{ll|}
$101.221,42$ \\
\end{tabular} & 99,68 \\
\hline Sertãozinho & & & 295,41 & 05 & $423.630,49$ & & & & & 6,00 & \begin{tabular}{|l|l|}
$74.403,89$ \\
\end{tabular} & $17.851 .250,94$ \\
\hline Sobrado & & & & & $695.037,72$ & & $170 . .5$ & & & & $122.072,21$ & $29.288 .007,43$ \\
\hline Sossêgo & 3. & 651 & $.696,71$ & $37.700,03$ & $303.886,51$ & $26.062,29$ & $56.966,71$ & $8.659,79$ & \begin{tabular}{|l|l|}
$44.949,07$ \\
\end{tabular} & $6.046 .948,00$ & \begin{tabular}{|l|l|}
$53.372,78$ \\
\end{tabular} & $12.805 .391,73$ \\
\hline $\begin{array}{l}\text { Tenór } \\
\end{array}$ & & 5 & $128.697,11$ & $79.700,03$ & $267.393,99$ & $41.202 .908,01$ & \begin{tabular}{|l|}
$56.966,71$ \\
\end{tabular} & $11.278 .659,79$ & \begin{tabular}{|l|l|}
$44.949,07$ \\
\end{tabular} & $6.046 .948,00$ & \begin{tabular}{|l|l|}
$46.963,46$ \\
\end{tabular} & $11.267 .643,52$ \\
\hline Triunfo & & & & &, 62 & $132.971 .060,18$ & \begin{tabular}{|l|}
$227.866,82$ \\
\end{tabular} & $45.114 .639,18$ & 179.796,29 & & $151.561,66$ & $36.363 .222,33$ \\
\hline Umbuzeiro & 9. & 19 & 490,20 & & $905.126,34$ & 4,06 & \begin{tabular}{|l|l|}
$227.866,82$ \\
\end{tabular} & & \begin{tabular}{|l|l|}
$179.796,29$ \\
\end{tabular} & 791,99 & \begin{tabular}{|l|l|}
$158.970,90$ \\
\end{tabular} & 74,99 \\
\hline & & & & & & & & & & & & \\
\hline $\begin{array}{l}\text { Vieirópolis } \\
\end{array}$ & & 1020 & 494,85 & 05 & $476.175,97$ & 63 & $113.933,41$ & 22.557. & $89.898,14$ & $12.093 .896,00$ & $83.632,66$ & $20.065 .451,04$ \\
\hline Vista Se & & 714 & 996,38 & 0,04 & 79,18 & 606,42 & \begin{tabular}{|l|l|}
$113.933,41$ \\
\end{tabular} & $22.557 .319,59$ & $89.898,14$ & $12.093 .896,00$ & $58.552,70$ & $14.048 .175,45$ \\
\hline Zabelêt & 2.109 & 422 & 497,88 & $16.579 .500,02$ & $96.835,58$ & $30.330 .517,62$ & $56.966,71$ & $11.278 .659,79$ & $\begin{array}{l}44.949,07 \\
\end{array}$ & $6.046 .948,00$ & $34.571,01$ & $8.294 .401,46$ \\
\hline
\end{tabular}




\section{B.6 - Consolidação dos resultados para Pernambuco}

\begin{tabular}{|c|c|c|c|c|c|c|c|c|c|c|c|c|}
\hline & & & \multirow{2}{*}{\multicolumn{4}{|c|}{ Solar Fotovoltaica }} & \multirow{2}{*}{\multicolumn{4}{|c|}{ Biomassa }} & \multirow{3}{*}{\multicolumn{2}{|c|}{ Eólica }} \\
\hline & & & & & & & & & & & & \\
\hline & & & \multicolumn{2}{|c|}{\begin{tabular}{|l|} 
Minirredes \\
\end{tabular}} & \multicolumn{2}{|c|}{ Sistemas isolados } & \multicolumn{2}{|c|}{ Resíduos Agrícolas } & \multicolumn{2}{|c|}{ Óleo de dendê } & & \\
\hline Município & $\begin{array}{c}\text { № de } \\
\text { habitantes } \\
\text { projetados } \\
(2012)\end{array}$ & $\begin{array}{c}\mathbf{N}^{\circ} \text { de } \\
\text { Fam ílias } \\
\text { (5 pessoas) }\end{array}$ & $\begin{array}{l}\text { Custo } \\
\text { evitado } \\
\text { (R\$) }\end{array}$ & \begin{tabular}{|c|} 
Custo do \\
empreendimento \\
considerando a \\
externalidade (R\$)
\end{tabular} & $\begin{array}{c}\text { Custo } \\
\text { evitado } \\
\text { (R\$) }\end{array}$ & \begin{tabular}{|c|} 
Custo do \\
empreendimento \\
considerando a \\
externalidade $(R \$)$
\end{tabular} & $\begin{array}{c}\text { Custo } \\
\text { evitado }(R \$)\end{array}$ & \begin{tabular}{|c|} 
Custo do \\
empreendimento \\
considerando a \\
externalidade (R\$)
\end{tabular} & $\begin{array}{c}\text { Custo } \\
\text { evitado } \\
\text { (R\$) }\end{array}$ & \begin{tabular}{|c|} 
Custo do \\
empreendimento \\
considerando a \\
externalidade $(R \$)$
\end{tabular} & $\begin{array}{c}\text { Custo } \\
\text { evitado } \\
\text { (R\$) }\end{array}$ & $\begin{array}{c}\text { Custo do } \\
\text { empreendimento } \\
\text { considerando a } \\
\text { externalidade (R\$) }\end{array}$ \\
\hline Brejão & 8.834 & 1767 & \begin{tabular}{|l|}
$397.791,07$ \\
\end{tabular} & $69.791 .800,09$ & $824.488,15$ & $127.045 .895,05$ & $\mid 227.866,82$ & $45.114 .639,18$ & $179.796,29$ & $24.187 .791,99$ & \begin{tabular}{|l|}
$144.808,10$ \\
\end{tabular} & $34.742 .884,07$ \\
\hline Brejinho & 312 & 1462 & $329.392,60$ & $57.791 .400,08$ & $682.438,01$ & $105.157 .299,59$ & \begin{tabular}{|l|}
$170.900,12$ \\
\end{tabular} & $33.835 .979,38$ & $134.847,22$ & $18.140 .843,99$ & $119.859,28$ & $28.757 .071,35$ \\
\hline Calumbi & 5.643 & 1129 & $253.794,30$ & $44.527 .800,06$ & $526.668,17$ & $81.154 .628,23$ & $170.900,12$ & $33.835 .979,38$ & $134.847,22$ & $18.140 .843,99$ & $92.500,81$ & $22.193 .128,23$ \\
\hline Camutanga & 8.204 & 1641 & $368.991,71$ & $64.739 .000,09$ & $765.689,47$ & $117.985 .569,73$ & $\mid 227.866,82$ & $45.114 .639,18$ & $179.796,29$ & $24.187 .791,99$ & $134.481,06$ & $32.265 .182,35$ \\
\hline ernando de Noronha & 18 & 544 & $122.397,25$ & $1.474 .400,03$ & $253.674,30$ & $39.088 .832,10$ & $56.966,71$ & $11.278 .659,79$ & $44.949,07$ & $6.046 .948,00$ & $444.553,82$ & $10.689 .513,12$ \\
\hline Granito & 68 & 394 & \begin{tabular}{|l|}
$313.192,97$ \\
\end{tabular} & $4.949 .200,07$ & $650.332,06$ & $100.210 .074,34$ & $170.900,12$ & $33.835 .979,38$ & $134.847,22$ & $18.140 .843,99$ & $114.220,38$ & $27.404 .167,55$ \\
\hline Ibirajuba & 549 & 510 & $339.292,38$ & $59.528 .300,08$ & $704.557,51$ & $108.565 .707,69$ & $170.900,12$ & $33.835 .979,38$ & $134.847,22$ & $18.140 .843,99$ & $123.744,21$ & $29.689 .159,14$ \\
\hline Ingazeira & 486 & 397 & $201.595,47$ & $35.369 .600,05$ & $418.683,93$ & $64.515 .268,87$ & $113.933,41$ & $22.557 .319,59$ & $89.898,14$ & $12.093 .896,00$ & \begin{tabular}{|l|}
$73.535,11$ \\
\end{tabular} & $17.642 .809,36$ \\
\hline Itacuruba & 475 & & \begin{tabular}{|l|}
$201.595,47$ \\
\end{tabular} & $5.369 .600,05$ & $417.657,29$ & $4.357 .072,71$ & $113.933,41$ & $22.557 .319,59$ & $89.898,14$ & $12.093 .896,00$ & \begin{tabular}{|l|}
$73.354,79$ \\
\end{tabular} & $17.599 .547,91$ \\
\hline Palmeirina & 8.172 & 1634 & $368.091,73$ & $64.581 .100,09$ & $762.702,87$ & $117.525 .362,73$ & \begin{tabular}{|l|}
$227.866,82$ \\
\end{tabular} & $45.114 .639,18$ & $179.796,29$ & $24.187 .791,99$ & $133.956,51$ & $32.139 .330,83$ \\
\hline Quixabá & 6.722 & 1344 & $302.393,21$ & $53.054 .400,07$ & $627.372,58$ & $96.672 .233,02$ & $170.900,12$ & $33.835 .979,38$ & $134.847,22$ & $18.140 .843,99$ & $110.187,92$ & $26.436 .684,03$ \\
\hline Salgadinho & 9.641 & 1928 & $433.790,26$ & $76.107 .800,10$ & $899.806,46$ & $138.651 .740,34$ & $\mid 227.866,82$ & $45.114 .639,18$ & $179.796,29$ & $24.187 .791,99$ & \begin{tabular}{|l|}
$158.036,55$ \\
\end{tabular} & $37.916 .701,98$ \\
\hline Solidão & 5.777 & 1155 & $260.094,16$ & $45.633 .100,06$ & $539.174,56$ & $83.081 .745,04$ & $170.900,12$ & $33.835 .979,38$ & $134.847,22$ & $18.140 .843,99$ & \begin{tabular}{|l|}
$94.697,35$ \\
\end{tabular} & $22.720 .131,45$ \\
\hline Terezinha & 6.803 & 1361 & $305.993,13$ & $53.686 .000,07$ & $634.932,41$ & $97.837 .131,99$ & $170.900,12$ & $33.835 .979,38$ & $134.847,22$ & $18.140 .843,99$ & \begin{tabular}{|l|}
$111.515,68$ \\
\end{tabular} & $26.755 .245,68$ \\
\hline Terra Nova & 534 & 1907 & $429.290,36$ & $75.318 .300,10$ & $889.820,02$ & $137.112 .923,18$ & $227.866,82$ & $45.114 .639,18$ & $179.796,29$ & $24.187 .791,99$ & $156.282,59$ & $37.495 .885,97$ \\
\hline Tuparetama & 50 & 990 & $58.191,96$ & $62.844 .200,08$ & $741.983,34$ & $4.332 .676,66$ & $227.866,82$ & $45.114 .639,18$ & $179.796,29$ & $24.187 .791,99$ & $130.317,46$ & $31.266 .235,94$ \\
\hline Verdejante & & 31 & \begin{tabular}{|l|}
$413.090,72$ \\
\end{tabular} & $.476 .100,10$ & $857.434,08$ & $132.122 .553,52$ & $227.866,82$ & $45.114 .639,18$ & $179.796,29$ & $24.187 .791,99$ & \begin{tabular}{|l|}
$150.594,52$ \\
\end{tabular} & $36.131 .183,60$ \\
\hline Vertente do Lério & 7.773 & 1555 & \begin{tabular}{|l|}
$350.092,14$ \\
\end{tabular} & $61.423 .100,08$ & $725.463,71$ & $111.787 .156,69$ & $227.866,82$ & $45.114 .639,18$ & $179.796,29$ & $24.187 .791,99$ & \begin{tabular}{|l|}
$127.416,05$ \\
\end{tabular} & $30.570 .119,75$ \\
\hline
\end{tabular}


B.7 - Consolidação dos resultados para o Piauí

\begin{tabular}{|c|c|c|c|c|c|c|c|c|c|c|c|c|}
\hline & & & \multirow{2}{*}{\multicolumn{4}{|c|}{ Solar Fotovoltaica }} & & & & & \multirow{3}{*}{\multicolumn{2}{|c|}{ Eólica }} \\
\hline & & & & & & & \multicolumn{4}{|c|}{ Biomassa } & & \\
\hline & & & \multicolumn{2}{|c|}{ Minirredes } & \multicolumn{2}{|c|}{ Sistemas isolados } & \multicolumn{2}{|c|}{ Resíduos Agrícolas } & \multicolumn{2}{|c|}{ Óleo de dendê } & & \\
\hline Município & \begin{tabular}{|c|} 
№ de \\
habitantes \\
projetados \\
$(2012)$
\end{tabular} & $\begin{array}{c}\mathrm{N}^{\circ} \text { de } \\
\text { Fam ílias } \\
\text { (5 pessoas) }\end{array}$ & $\begin{array}{l}\text { Custo } \\
\text { evitado } \\
\text { (R\$) }\end{array}$ & $\begin{array}{c}\text { Custo do } \\
\text { empreendimento } \\
\text { considerando a } \\
\text { externalidade (R\$) }\end{array}$ & $\begin{array}{c}\text { Custo } \\
\text { evitado } \\
\text { (R\$) }\end{array}$ & $\begin{array}{c}\text { Custo do } \\
\text { empreendimento } \\
\text { considerando a } \\
\text { externalidade (R\$) }\end{array}$ & $\begin{array}{c}\text { Custo } \\
\text { evitado (R\$) }\end{array}$ & $\begin{array}{c}\text { Custo do } \\
\text { empreendimento } \\
\text { considerando a } \\
\text { externalidade (R\$) }\end{array}$ & $\begin{array}{l}\text { Custo } \\
\text { evitado } \\
\text { (R\$) }\end{array}$ & \begin{tabular}{|c|} 
Custo do \\
empreendimento \\
considerando a \\
externalidade $(R \$)$
\end{tabular} & $\begin{array}{c}\text { Custo } \\
\text { evitado } \\
\text { (R\$) }\end{array}$ & $\begin{array}{c}\text { Custo do } \\
\text { empreendimento } \\
\text { considerando a } \\
\text { externalidade ( } R \$ \text { ) }\end{array}$ \\
\hline Acauã & 6.840 & 1368 & $307.793,09$ & $54.001 .800,07$ & $638.385,66$ & $98.369 .246,34$ & $170.900,12$ & $33.835 .979,38$ & $134.847,22$ & $18.140 .843,99$ & $112.122,19$ & $26.900 .761,49$ \\
\hline Agricolândia & 5.062 & 1012 & $227.694,89$ & $39.948 .700,05$ & \begin{tabular}{|l|l}
$472.442,72$ \\
\end{tabular} & $72.798 .994,88$ & $113.933,41$ & $22.557 .319,59$ & $89.898,14$ & $12.093 .896,00$ & $82.976,98$ & $19.908 .136,65$ \\
\hline Alagoinha do Piauí & 7.413 & 1483 & $333.892,50$ & $58.580 .900,08$ & $691.864,46$ & $106.609 .827,94$ & $170.900,12$ & $33.835 .979,38$ & $134.847,22$ & $18.140 .843,99$ & $121.514,88$ & $29.154 .290,20$ \\
\hline Alegrete do Piauí & 173 & 1035 & $33.094,77$ & $0.896 .100,05$ & \begin{tabular}{|l}
$482.802,49$ \\
\end{tabular} & $74.395 .337,91$ & $113.933,41$ & $22.557 .319,59$ & $89.898,14$ & $12.093 .896,00$ & \begin{tabular}{|l|}
$84.796,50$ \\
\end{tabular} & $20.344 .684,09$ \\
\hline Alvorada do Gurguéia & 177 & 335 & $233.094,77$ & $0.896 .100,05$ & $83.175,82$ & $74.452 .863,78$ & $113.933,41$ & $22.557 .319,59$ & $89.898,14$ & $12.093 .896,00$ & $84.862,07$ & $20.360 .415,53$ \\
\hline Angical do Piaú & 555 & 1331 & $99.693,27$ & $2.580 .700,07$ & $21.119,38$ & $95.708 .674,62$ & $170.900,12$ & $33.835 .979,38$ & $134.847,22$ & $18.140 .843,99$ & $109.089,64$ & 32,42 \\
\hline Anísio de Abreu & 385 & 877 & $22.090,52$ & $74.055 .100,10$ & \begin{tabular}{|l|}
$875.913,66$ \\
\end{tabular} & $134.970 .084,34$ & $227.866,82$ & $45.114 .639,18$ & \begin{tabular}{|l|}
$179.796,29$ \\
\end{tabular} & $24.187 .791,99$ & \begin{tabular}{|l|}
$153.840,17$ \\
\end{tabular} & $36.909 .889,85$ \\
\hline Antônio Almeida & 68 & 14 & $77.696,91$ & $4.158 .700,03$ & $36.340,24$ & $44.122 .346,16$ & $56.966,71$ & $11.278 .659,79$ & $44.949,07$ & $6.046 .948,00$ & $50.291,06$ & 4,07 \\
\hline Aroazes & 42 & 1148 & $258.294,20$ & $.317 .300,06$ & $535.907,96$ & 82.578 .3 & $170.900,12$ & $33.835 .979,38$ & $134.847,22$ & $18.140 .843,99$ & $94.123,63$ & $2.582 .481,36$ \\
\hline Arraial & 4.655 & 931 & $209.695,29$ & $36.790 .700,05$ & \begin{tabular}{|l}
$434.456,91$ \\
\end{tabular} & $66.945 .737,09$ & $113.933,41$ & $22.557 .319,59$ & $89.898,14$ & $12.093 .896,00$ & $76.305,38$ & $18.307 .462,68$ \\
\hline Assunção do Piauí & 7.590 & 1518 & $341.992,32$ & $60.002 .000,08$ & \begin{tabular}{|l|}
$708.384,09$ \\
\end{tabular} & $109.155 .347,91$ & $170.900,12$ & $33.835 .979,38$ & $134.847,22$ & $18.140 .843,99$ & $124.416,29$ & $29.850 .406,39$ \\
\hline Barra d’Alcântara & 558 & 772 & $173.696,10$ & $30.474 .700,04$ & \begin{tabular}{|l|}
$360.071,91$ \\
\end{tabular} & $55.483 .706,49$ & $113.933,41$ & $22.557 .319,59$ & \begin{tabular}{|l|}
$89.898,14$ \\
\end{tabular} & $12.093 .896,00$ & \begin{tabular}{|l|}
$63.240,85$ \\
\end{tabular} & $15.172 .973,37$ \\
\hline Barreiras do Piaú & 255 & 51 & $146.696,71$ & $25.737 .700,03$ & \begin{tabular}{|l|}
$303.793,18$ \\
\end{tabular} & $46.811 .680,82$ & $56.966,71$ & $11.278 .659,79$ & $44.949,07$ & $6.046 .948,00$ & $53.356,39$ & $12.801 .458,87$ \\
\hline Barro Duro & 880 & 1316 & $296.093,35$ & $51.949 .100,07$ & $614.119,54$ & $94.630 .064,46$ & $170.900,12$ & $33.835 .979,38$ & $134.847,22$ & $18.140 .843,99$ & $107.860,23$ & $25.878 .217,93$ \\
\hline Bela Vista do Piauí & 354 & 771 & $173.696,10$ & $30.474 .700,04$ & \begin{tabular}{|l|}
$359.698,59$ \\
\end{tabular} & $55.426 .180,61$ & $113.933,41$ & $22.557 .319,59$ & \begin{tabular}{|l|}
$89.898,14$ \\
\end{tabular} & $12.093 .896,00$ & $63.175,28$ & $15.157 .241,93$ \\
\hline Belém do Piauí & 88 & & \begin{tabular}{|l|}
$152.096,58$ \\
\end{tabular} & $26.685 .100,04$ & \begin{tabular}{|l|}
$316.206,23$ \\
\end{tabular} & $48.724 .416,17$ & $113.933,41$ & $22.557 .319,59$ & $89.898,14$ & $12.093 .896,00$ & \begin{tabular}{|l|}
$55.536,55$ \\
\end{tabular} & $13.324 .529,23$ \\
\hline Beneditinos & 9.943 & 1989 & \begin{tabular}{|l}
$447.289,95$ \\
\end{tabular} & $78.476 .300,11$ & \begin{tabular}{|l|}
$927.992,49$ \\
\end{tabular} & $142.994 .943,91$ & $284.833,53$ & $56.393 .298,97$ & $224.745,36$ & $30.234 .739,99$ & $162.986,98$ & $39.104 .425,66$ \\
\hline Bertolínia & 5.350 & 1070 & $241.194,58$ & $42.317 .200,06$ & $499.322,12$ & $76.940 .857,88$ & $113.933,41$ & $22.557 .319,59$ & $89.898,14$ & $12.093 .896,00$ & $87.697,91$ & $21.040 .800,29$ \\
\hline Betânia do Piauí & 6.042 & 1208 & $271.793,90$ & $47.685 .800,06$ & \begin{tabular}{|l|}
$563.907,34$ \\
\end{tabular} & $86.892 .834,26$ & $170.900,12$ & $33.835 .979,38$ & $134.847,22$ & $18.140 .843,99$ & \begin{tabular}{|l|}
$99.041,27$ \\
\end{tabular} & $23.762 .339,32$ \\
\hline Boa Hora & 6.467 & 1293 & $290.693,47$ & $51.001 .700,07$ & $603.573,11$ & $93.004 .958,49$ & $170.900,12$ & $33.835 .979,38$ & $134.847,22$ & $18.140 .843,99$ & $106.007,92$ & $25.433 .804,76$ \\
\hline Bocaina & & 870 & $197.995,55$ & $.738 .000,05$ & \begin{tabular}{|l|}
$410.097,46$ \\
\end{tabular} & $63.192 .173,74$ & $113.933,41$ & $22.557 .319,59$ & \begin{tabular}{|l|}
$89.898,14$ \\
\end{tabular} & $12.093 .896,00$ & \begin{tabular}{|l|}
$72.027,03$ \\
\end{tabular} & $17.280 .986,26$ \\
\hline Bom Princípio do Piaú & & & $242.994,54$ & $42.633 .000,06$ & $504.642,00$ & $77.760 .601,60$ & $113.933,41$ & $22.557 .319,59$ & $89.898,14$ & $12.093 .896,00$ & $88.632,26$ & 3,30 \\
\hline Bonfim do Piaú & 71 & 1094 & $246.594,46$ & $43.264 .600,06$ & $510.615,20$ & $78.681 .015,60$ & $170.900,12$ & $33.835 .979,38$ & $134.847,22$ & $18.140 .843,99$ & $89.681,36$ & $21.516 .676,33$ \\
\hline Boqueirão do Piauí & 88 & 258 & $82.593,65$ & $49.580 .600,07$ & \begin{tabular}{|l|}
$586.866,82$ \\
\end{tabular} & $90.430 .675,58$ & $170.900,12$ & $33.835 .979,38$ & \begin{tabular}{|l|}
$134.847,22$ \\
\end{tabular} & $18.140 .843,99$ & \begin{tabular}{|l|}
$103.073,73$ \\
\end{tabular} & $24.729 .822,84$ \\
\hline Brasileira & 57 & 1611 & $362.691,85$ & $63.633 .700,09$ & \begin{tabular}{|l|}
$751.969,78$ \\
\end{tabular} & $115.871 .493,82$ & $227.866,82$ & $45.114 .639,18$ & $179.796,29$ & $24.187 .791,99$ & $132.071,41$ & $31.687 .051,95$ \\
\hline Brejo do Piauí & 3.724 & 745 & $167.396,24$ & $29.369 .400,04$ & \begin{tabular}{|l}
$347.565,53$ \\
\end{tabular} & $53.556 .589,67$ & $113.933,41$ & $22.557 .319,59$ & $89.898,14$ & $12.093 .896,00$ & $61.044,30$ & $14.645 .970,15$ \\
\hline Buriti dos Montes & 8.079 & 1616 & $363.591,83$ & $63.791 .600,09$ & \begin{tabular}{|l}
$754.023,07$ \\
\end{tabular} & $116.187 .886,13$ & $227.866,82$ & $45.114 .639,18$ & $179.796,29$ & $24.187 .791,99$ & $132.432,04$ & $31.773 .574,87$ \\
\hline Cajazeiras do Piauí & 3.413 & 683 & $153.896,54$ & $27.000 .900,04$ & \begin{tabular}{|l|}
$318.539,51$ \\
\end{tabular} & $49.083 .952,89$ & $113.933,41$ & $22.557 .319,59$ & \begin{tabular}{|l|}
$89.898,14$ \\
\end{tabular} & $12.093 .896,00$ & $55.946,35$ & $13.422 .850,73$ \\
\hline Cajueiro da Praia & 7.321 & 1464 & $329.392,60$ & $57.791 .400,08$ & \begin{tabular}{|c|}
$683.277,99$ \\
\end{tabular} & $105.286 .732,81$ & $170.900,12$ & $33.835 .979,38$ & $134.847,22$ & $18.140 .843,99$ & $120.006,80$ & $28.792 .467,09$ \\
\hline $\begin{array}{c}\text { Caldeirão Grande do } \\
\text { Piauí }\end{array}$ & 5.700 & 1 & 4 & 6 & 5 & 5 & $170.900,12$ & $33.835 .979,38$ & 2 & 9 & 16 & 4 \\
\hline Campinas do Piauí & 5.449 & 1090 & $44.794,50$ & $42.948 .800,06$ & $508.561,91$ & $78.364 .623,29$ & $170.900,12$ & $33.835 .979,38$ & $134.847,22$ & $18.140 .843,99$ & $89.320,73$ & $21.430 .153,42$ \\
\hline
\end{tabular}




\begin{tabular}{|c|c|c|c|c|c|c|c|c|c|c|c|c|}
\hline & & & & & & & \multirow{2}{*}{\multicolumn{4}{|c|}{\begin{tabular}{|c|c|}
\multicolumn{2}{c}{ Biomassa } \\
Resíduos Aqrícolas Óleo de dendê
\end{tabular}}} & & \\
\hline & \multicolumn{2}{|c|}{ Minirredes } & \multicolumn{2}{|c|}{ Sistemas isolados } & & & & & \multicolumn{2}{|r|}{ Eólica } \\
\hline Municipio & $\begin{array}{c}\text { № de } \\
\text { habitantes } \\
\text { projetados } \\
\text { (2012) }\end{array}$ & $\begin{array}{c}\mathrm{N}^{\circ} \text { de } \\
\text { Fam ílias } \\
\text { (5 pessoas) }\end{array}$ & $\begin{array}{l}\text { Custo } \\
\text { evitado } \\
\text { (R\$) }\end{array}$ & \begin{tabular}{|c|} 
Custo do \\
empreendimento \\
considerando a \\
externalidade (R\$)
\end{tabular} & $\begin{array}{l}\text { Custo } \\
\text { evitado } \\
\text { (R\$) }\end{array}$ & \begin{tabular}{|c|} 
Custo do \\
empreendimento \\
considerando a \\
externalidade (RS)
\end{tabular} & $\begin{array}{c}\text { Custo } \\
\text { evitado (R\$) }\end{array}$ & \begin{tabular}{|c|} 
Custo do \\
empreendimento \\
considerando a \\
externalidade (R\$)
\end{tabular} & $\begin{array}{c}\text { Custo } \\
\text { evitado } \\
\text { (R\$) }\end{array}$ & \begin{tabular}{|c|} 
Custo do \\
empreendimento \\
considerando a \\
externalidade (RS)
\end{tabular} & $\begin{array}{c}\text { Custo } \\
\text { evitado } \\
\text { (R\$) }\end{array}$ & $\begin{array}{c}\text { Custo do } \\
\text { empreendimento } \\
\text { considerando a } \\
\text { externalidade ( } \mathrm{BS} \text { ) }\end{array}$ \\
\hline $\begin{array}{l}\text { Campo Alegre do } \\
\text { Fidalgo }\end{array}$ & 4.815 & 963 & $216.895,13$ & $38.053 .900,05$ & $449.389,91$ & $69.246 .772,09$ & $113.933,41$ & $22.557 .319,59$ & $89.898,14$ & $12.093 .896,00$ & $78.928,12$ & $18.936 .720,26$ \\
\hline Campo Grande do Piauí & 5.704 & 1141 & \begin{tabular}{|l|}
$256.494,24$ \\
\end{tabular} & $45.001 .500,06$ & $532.361,38$ & $82.031 .897,82$ & \begin{tabular}{|l|}
$170.900,12$ \\
\end{tabular} & $33.835 .979,38$ & $134.847,22$ & $18.140 .843,99$ & $93.500,73$ & $22.433 .032,68$ \\
\hline Campo Largo do Piauí & 6.964 & 1393 & $\begin{array}{l}13.192,97 \\
\end{array}$ & $54.949 .200,07$ & $649.958,74$ & $100.152 .548,46$ & \begin{tabular}{|l|}
$170.900,12$ \\
\end{tabular} & $33.835 .979,38$ & $134.847,22$ & $18.140 .843,99$ & $114.154,81$ & $27.388 .436,11$ \\
\hline Canavieira & 3.892 & 778 & $175.496,06$ & $30.790 .500,04$ & $363.245,18$ & $55.972 .676,42$ & $113.933,41$ & $22.557 .319,59$ & $89.898,14$ & $12.093 .896,00$ & $63.798,18$ & $15.306 .690,60$ \\
\hline $\begin{array}{l}\text { Capitão Gervásio } \\
\text { Oliveira }\end{array}$ & 3.946 & 789 & 177.296,02 & $31.106 .300,04$ & $368.285,06$ & $56.749 .275,74$ & 113.933,41 & 22.557.319,59 & $89.898,14$ & $12.093 .896,00$ & $64.683,36$ & $15.519 .065,04$ \\
\hline Caraúbas do Piaú & 5.634 & 1127 & 30 & 06 & 19 & 01 & \begin{tabular}{|l|}
17 \\
\end{tabular} & $33.835 .979,38$ & 13 & 99 & 28 & $22.157 .732,49$ \\
\hline Caridade do Piaú & 4.915 & 983 & $221.395,03$ & $38.843 .400,05$ & $458.723,03$ & $70.684 .918,97$ & \begin{tabular}{|l|}
$113.933,41$ \\
\end{tabular} & $22.557 .319,59$ & $89.898,14$ & $12.093 .896,00$ & $80.567,33$ & $19.330 .006,25$ \\
\hline Caxingó & & & $3.094,77$ & & $482.895,82$ & 9,38 & $113.933,41$ & & $89.898,14$ & & & \\
\hline Cocal de Telha & 4.567 & 913 & $205.195,39$ & $36.001 .200,05$ & $426.243,76$ & $65.680 .167,84$ & \begin{tabular}{|l|}
$113.933,41$ \\
\end{tabular} & $22.557 .319,59$ & $89.898,14$ & $12.093 .896,00$ & $74.862,87$ & 17.961. \\
\hline Cocal dos Alves & 5.635 & 1127 & $253.794,30$ & $44.527 .800,06$ & $525.921,52$ & $81.039 .576,48$ & \begin{tabular}{|l|}
$170.900,12$ \\
\end{tabular} & $33.835 .979,38$ & $134.847,22$ & $18.140 .843,99$ & $92.369,67$ & $22.161 .665,35$ \\
\hline Coivaras & & & $174.596,08$ & & $361.378,55$ & & \begin{tabular}{|l|}
$113.933,41$ \\
\end{tabular} & & $89.898,14$ & & & \\
\hline Colônia do Gurguéia & 6.191 & 1238 & \begin{tabular}{|l|}
$278.993,73$ \\
\end{tabular} & $48.949 .000,07$ & $577.813,69$ & $89.035 .673,11$ & \begin{tabular}{|l|}
$170.900,12$ \\
\end{tabular} & $33.835 .979,38$ & $134.847,22$ & $18.140 .843,99$ & $101.483,69$ & $24.348 .335,44$ \\
\hline Colônia do Piauí & 7.461 & 1492 & $335.692,46$ & $58.896 .700,08$ & $696.344,36$ & $107.300 .138,44$ & \begin{tabular}{|l|}
$170.900,12$ \\
\end{tabular} & $33.835 .979,38$ & $134.847,22$ & $18.140 .843,99$ & $122.301,70$ & $29.343 .067,47$ \\
\hline indé & & & 202.4 & & 7,24 & & $113.933,41$ & & 8,14 & & & 7,96 \\
\hline Coronel José Dias & 4.561 & 912 & \begin{tabular}{|l|}
$205.195,39$ \\
\end{tabular} & $36.001 .200,05$ & $425.683,77$ & $65.593 .879,03$ & \begin{tabular}{|l|}
$113.933,41$ \\
\end{tabular} & $22.557 .319,59$ & $89.898,14$ & $12.093 .896,00$ & $74.764,52$ & $17.937 .773,85$ \\
\hline Cristalândia do Piaú & 7.973 & 1595 & $359.091,94$ & $63.002 .100,08$ & $744.129,95$ & $114.663 .450,45$ & \begin{tabular}{|l|}
$227.866,82$ \\
\end{tabular} & $45.114 .639,18$ & $179.796,29$ & $24.187 .791,99$ & $130.694,48$ & $31.356 .691,72$ \\
\hline & & & & & & & \begin{tabular}{|l|}
$113.933,41$ \\
\end{tabular} & & & & & \\
\hline Curral Novo do Piaú & 4.990 & 998 & \begin{tabular}{|l|}
$224.994,95$ \\
\end{tabular} & $39.475 .000,05$ & $465.722,87$ & $71.763 .529,13$ & \begin{tabular}{|l|}
$113.933,41$ \\
\end{tabular} & $22.557 .319,59$ & $89.898,14$ & $12.093 .896,00$ & $81.796,74$ & $19.624 .970,74$ \\
\hline Curralinhos & 4.265 & & 191.695,69 & $33.632 .700,05$ & $398.057,73$ & $61.336 .964,27$ & \begin{tabular}{|l|}
$113.933,41$ \\
\end{tabular} & $22.557 .319,59$ & $89.898,14$ & $12.093 .896,00$ & $69.912,45$ & $16.773 .647,33$ \\
\hline Dirceu & & & $304.193,17$ & & $631.572,48$ & 9,12 & \begin{tabular}{|l|}
$170.900,12$ \\
\end{tabular} & $33.835 .979,38$ & $134.847,22$ & 43,99 & $110.925,56$ & 26.6 \\
\hline Dom Expedito Lopes & & 13 & \begin{tabular}{|l|}
$299.693,27$ \\
\end{tabular} & $52.580 .700,07$ & $621.772,70$ & $95.809 .344,90$ & \begin{tabular}{|l|}
$170.900,12$ \\
\end{tabular} & $33.835 .979,38$ & $134.847,22$ & $18.140 .843,99$ & $109.204,39$ & $26.200 .712,43$ \\
\hline Dom Inocêncio & & & $418.490,60$ & $73.423 .500,10$ & $867.607,18$ & $133.690 .133,62$ & \begin{tabular}{|l|}
$227.866,82$ \\
\end{tabular} & $45.114 .639,18$ & $179.796,29$ & $24.187 .791,99$ & 152.381,27 & $36.559 .865,32$ \\
\hline Domingos Mourão & 4.261 & 852 & $191.695,69$ & $33.632 .700,05$ & $397.684,40$ & $61.279 .438,40$ & \begin{tabular}{|l|}
$113.933,41$ \\
\end{tabular} & $22.557 .319,59$ & $89.898,14$ & $12.093 .896,00$ & \begin{tabular}{|l|l|}
$69.846,88$ \\
\end{tabular} & $16.757 .915,89$ \\
\hline Eliseu Martins & 4.738 & 948 & \begin{tabular}{|l|}
$213.295,21$ \\
\end{tabular} & $7.422 .300,05$ & $442.203,40$ & $68.139 .399,00$ & \begin{tabular}{|l|}
$113.933,41$ \\
\end{tabular} & $22.557 .319,59$ & $89.898,14$ & $12.093 .896,00$ & $77.665,93$ & $18.633 .890,05$ \\
\hline Fartura do Piaú & & & $231.294,81$ & $580.300,05$ & $479.069,24$ & $73.820 .079,16$ & \begin{tabular}{|l|}
$113.933,41$ \\
\end{tabular} & $22.557 .319,59$ & $89.898,14$ & $12.093 .896,00$ & $84.140,82$ & $20.187 .369,70$ \\
\hline Flores do Piauí & 4.366 & 873 & \begin{tabular}{|l|l|}
$196.195,59$ \\
\end{tabular} & $34.422 .200,05$ & $407.484,18$ & $62.789 .492,62$ & \begin{tabular}{|l|}
$113.933,41$ \\
\end{tabular} & $22.557 .319,59$ & $89.898,14$ & $12.093 .896,00$ & $71.568,05$ & $17.170 .866,18$ \\
\hline Floresta do Piauí & & 4 & \begin{tabular}{|l|l|}
$112.497,47$ \\
\end{tabular} & 03 & 23 & & 6,71 & & 949,07 & 0 & 20 & \\
\hline Francinóolis & & & $235.794,70$ & $41.369 .800,06$ & $488.402,36$ & $75.258 .226,04$ & $1113.933,41$ & $22.557 .319,59$ & $89.898,14$ & $12.093 .896,00$ & $85.780,03$ & $20.580 .655,68$ \\
\hline Francisco Ayres & 4.363 & 873 & \begin{tabular}{|l|l|}
$196.195,59$ \\
\end{tabular} & $34.422 .200,05$ & $407.204,19$ & $62.746 .348,21$ & \begin{tabular}{|l|}
$113.933,41$ \\
\end{tabular} & $22.557 .319,59$ & $89.898,14$ & $12.093 .896,00$ & $71.518,88$ & $17.159 .067,60$ \\
\hline Francisco Macedo & & 5 & & & 9 & & 56 & & $44.949,07$ & 6.0 & & \\
\hline Francisco Santos & 8.857 & 17711 & $398.691,05$ & $69.949 .700,09$ & $826.634,77$ & $127.376 .668,83$ & \begin{tabular}{|l|l|}
$227.866,82$ \\
\end{tabular} & $\begin{array}{l}45.114 .639,18 \\
\end{array}$ & $179.796,29$ & $24.187 .791,99$ & $145.185,12$ & $34.833 .339,84$ \\
\hline Geminiano & 5.237 & 1047 & \begin{tabular}{|l|}
$235.794,70$ \\
\end{tabular} & $41.369 .800,06$ & $488.775,69$ & $75.315 .751,91$ & \begin{tabular}{|l|}
$113.933,41$ \\
\end{tabular} & $22.557 .319,59$ & $89.898,14$ & $12.093 .896,00$ & $85.845,60$ & $20.596 .387,12$ \\
\hline & & 88 & & & & & & & & & & \\
\hline Hugo Napole, & 3.782 & 756 & \begin{tabular}{|l|}
$170.096,18$ \\
\end{tabular} & $29.843 .100,04$ & $352.978,74$ & $54.390 .714,86$ & \begin{tabular}{|l|}
$113.9033,41$ \\
\end{tabular} & $22.557 .319,59$ & $89.898,14$ & $12.093 .896,00$ & $61.995,05$ & $14.874 .076,02$ \\
\hline
\end{tabular}




\begin{tabular}{|c|c|c|c|c|c|c|c|c|c|c|c|c|}
\hline & & & & & & & \multirow{2}{*}{\multicolumn{4}{|c|}{ Biomassa }} & \multirow{2}{*}{\multicolumn{2}{|c|}{ Eólica }} \\
\hline & \multicolumn{4}{|c|}{ Solar Fotovoltaica } & & & & & & \\
\hline Municipio & $\begin{array}{c}\text { № de } \\
\text { habitantes } \\
\text { projetados } \\
\text { (2012) }\end{array}$ & $\begin{array}{c}N^{\circ} \text { de } \\
\text { Fam ílias } \\
\text { (5 pessoas) }\end{array}$ & $\begin{array}{l}\text { Custo } \\
\text { evitado } \\
\text { (R\$) }\end{array}$ & \begin{tabular}{|c|} 
Custo do \\
empreendimento \\
considerando a \\
externalidade ( $\mathrm{R} \$$
\end{tabular} & $\begin{array}{c}\text { Custo } \\
\text { evitado } \\
\text { (R\$) }\end{array}$ & \begin{tabular}{|c|} 
Custo do \\
empreendimento \\
considerando a \\
externalidade (R\$)
\end{tabular} & $\begin{array}{c}\text { Custo } \\
\text { evitado (RS) }\end{array}$ & \begin{tabular}{|c|} 
Custo do \\
empreendimento \\
considerando a \\
externalidade (R\$)
\end{tabular} & $\begin{array}{c}\text { Custo } \\
\text { evitado } \\
\text { (R\$) }\end{array}$ & \begin{tabular}{|c|} 
Custo do \\
empreendimento \\
considerando a \\
externalidade (RS)
\end{tabular} & $\begin{array}{c}\text { Custo } \\
\text { evitado } \\
\text { (R\$) }\end{array}$ & \begin{tabular}{|c|} 
Custo do \\
empreendimento \\
considerando a \\
externalidade (R\$)
\end{tabular} \\
\hline Ilha Grande & 9.069 & 1814 & $407.690,84$ & $71.528 .700,10$ & $846.420,99$ & $130.425 .540,21$ & $227.866,82$ & $45.114 .639,18$ & $179.796,29$ & $24.187 .791,99$ & $148.660,25$ & $35.667 .106,14$ \\
\hline Ipiranga do Piaú & 9.463 & 1893 & $425.690,44$ & $74.686 .700,10$ & $883.193,50$ & $136.091 .838,90$ & $227.866,82$ & $45.114 .639,18$ & $1779.796,29$ & $24.187 .791,99$ & $155.118,75$ & $37.216 .652,92$ \\
\hline Isaías Coelho & 8.307 & 1661 & $373.491,61$ & $65.528 .500,09$ & $775.302,59$ & $119.466 .861,01$ & $227.866,82$ & $45.114 .639,18$ & $1779.796,29$ & $24.187 .791,99$ & $136.169,45$ & $32.670 .266,92$ \\
\hline Jacobina do Piaú & 5.670 & 1134 & $255.594,26$ & $44.843 .600,06$ & $529.188,12$ & $81.542 .927,88$ & $170.900,12$ & 33.835.979,38 & $134.847,22$ & $18.140 .843,99$ & $92.943,39$ & $22.299 .315,45$ \\
\hline Jardim do Mulato & 4.358 & 872 & $196.195,59$ & $34.422 .200,05$ & $406.737,53$ & $62.674 .440,87$ & $113.933,41$ & $22.557 .319,59$ & $89.898,14$ & $12.093 .896,00$ & $71.436,92$ & $17.139 .403,30$ \\
\hline Jatobá do Piauí & 4.708 & 942 & $211.495,25$ & $37.106 .500,05$ & $439.403,46$ & $67.707 .954,94$ & $113.933,41$ & $22.557 .319,59$ & $89.898,14$ & $12.093 .896,00$ & $77.174,16$ & $18.515 .904,25$ \\
\hline Jerumenha & 4.372 & 874 & $197.095,57$ & $34.580 .100,05$ & $408.044,17$ & $62.875 .781,43$ & $113.933,41$ & $22.557 .319,59$ & $89.898,14$ & $12.093 .896,00$ & $71.666,40$ & $17.194 .463,34$ \\
\hline João Costa & 2.951 & 590 & $133.197,01$ & $23.369 .200,03$ & $275.420,48$ & $42.439 .714,32$ & $56.966,71$ & $11.278 .659,79$ & $44.949,07$ & $6.046 .948,00$ & $48.373,18$ & $11.605 .869,47$ \\
\hline Joca Marques & 5.214 & 1043 & $234.894,72$ & $41.211 .900,06$ & $486.629,07$ & $74.984 .978,13$ & $113.933,41$ & $22.557 .319,59$ & $89.898,14$ & $12.093 .896,00$ & $85.468,58$ & $20.505 .931,35$ \\
\hline Juazeiro & 4. & 959 & 215.99 & 55 & $447.336,62$ & 78 & $113.933,41$ & 22. & 8,14 & 12. & 7,49 & 34 \\
\hline Júlio Borges & 5.439 & 1088 & $244.794,50$ & $42.948 .800,06$ & $507.628,60$ & $78.220 .808,60$ & $170.900,12$ & $33.835 .979,38$ & $134.847,22$ & 18.140 .8 & $89.156,81$ & 24,82 \\
\hline Jurema & 4.588 & 8 & \begin{tabular}{|l|}
$206.095,37$ \\
\end{tabular} & $36.159 .100,05$ & $428.203,72$ & $65.982 .178,68$ & $113.933,41$ & $22.557 .319,59$ & $89.898,14$ & $12.093 .896,00$ & $75.207,11$ & $18.043 .961,07$ \\
\hline Lagoa Aleg & 8.184 & 1637 & $368.091,73$ & $64.581 .100,09$ & $763.822,85$ & $117.697 .940,35$ & $227.866,82$ & $45.114 .639,18$ & $179.796,29$ & $24.187 .791,99$ & $134.153,22$ & $32.186 .525,15$ \\
\hline $\begin{array}{l}\text { Lagoa de São } \\
\text { Francisco }\end{array}$ & 6.517 & 1303 & $293.393,41$ & $51.475 .400,07$ & $608.239,67$ & 93.724.031,93 & $170.900,12$ & $33.835 .979,38$ & $134.847,22$ & $18.140 .843,99$ & $106.827,53$ & $25.630 .447,75$ \\
\hline goa do Barro do Piauí & 4.535 & 907 & 204.295,41 & $35.843 .300,05$ & $423.257,16$ & $65.219 .960,84$ & \begin{tabular}{|l|}
$113.933,41$ \\
\end{tabular} & $22.557 .319,59$ & $89.898,14$ & $12.093 .896,00$ & $74.338,32$ & $17.835 .519,50$ \\
\hline Lagoa do Piaúi & 3.920 & 784 & \begin{tabular}{|l|l|}
$176.396,04$ \\
\end{tabular} & $30.948 .400,04$ & $365.858,45$ & $56.375 .357,55$ & \begin{tabular}{|l|l|}
$113.933,41$ \\
\end{tabular} & $22.557 .319,59$ & $89.898,14$ & $12.093 .896,00$ & $64.257,16$ & 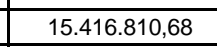 \\
\hline & & & & & & & \begin{tabular}{|l|l|}
$113.933,41$ \\
\end{tabular} & & & & & \\
\hline Lagoinha do Piaú & 2.721 & $a^{3}$ & \begin{tabular}{|l|}
$122.397,25$ \\
\end{tabular} & $21.474 .400,03$ & $253.954,30$ & $39.131 .976,50$ & \begin{tabular}{|l|l|}
$56.966,71$ \\
\end{tabular} & $11.278 .659,79$ & $44.949,07$ & $6.046 .948,00$ & $44.602,99$ & $10.701 .311,70$ \\
\hline Landri Sales & 5.229 & 1046 & $234.894,72$ & $41.211 .900,06$ & $488.029,04$ & $75.200 .700,16$ & $113.933,41$ & $22.557 .319,59$ & $89.898,14$ & $12.093 .896,00$ & \begin{tabular}{|l|l|}
$85.714,46$ \\
\end{tabular} & $20.564 .924,25$ \\
\hline & & & & & 744. & & $227.866,82$ & & 6,29 & & $130.710,87$ & \\
\hline Manoel Emídio & 5. & 16 & $234.894,72$ & $211.900,06$ & $487.469,05$ & $75.114 .411,35$ & \begin{tabular}{|l|l}
$113.933,41$ \\
\end{tabular} & $22.557 .319,59$ & $89.898,14$ & $12.093 .896,00$ & $85.616,11$ & $20.541 .327,09$ \\
\hline Marcolândia & 8.059 & 16 & $362.691,85$ & $.633 .700,09$ & $752.156,44$ & $115.900 .256,76$ & $227.866,82$ & 45. & $1799.796,29$ & 24. & $132.104,20$ & $31.694 .917,67$ \\
\hline Marco & & & & & 415.6 & & 113.93 & & 8,14 & $12.093 .896,00$ & \begin{tabular}{|l|l|}
$72.994,17$ \\
\end{tabular} & 24,99 \\
\hline Massapê do Piaú & 6.260 & 1252 & \begin{tabular}{|l|}
$281.693,67$ \\
\end{tabular} & $49.422 .700,07$ & $584.253,55$ & $90.027 .994,45$ & \begin{tabular}{|l|l|}
$170.900,12$ \\
\end{tabular} & $33.835 .979,38$ & $134.847,22$ & $18.140 .843,99$ & $102.614,75$ & $24.619 .702,77$ \\
\hline (1) & & & \begin{tabular}{|l|l|}
55.79 \\
\end{tabular} & 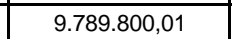 & $115.357,41$ & 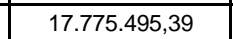 & 56.966 & 11.278 .6 & $44.949,07$ & 6.046 .9 & $20.260,68$ & $4.861 .014,80$ \\
\hline Mitton Brandão & 6.750 & 1350 & \begin{tabular}{|l|l|}
$304.193,17$ \\
\end{tabular} & $3.370 .200,07$ & $629.985,85$ & $97.074 .914,15$ & \begin{tabular}{|l|l|}
$170.900,12$ \\
\end{tabular} & 9,38 & $134.847,22$ & $18.140 .843,99$ & $\begin{array}{l}110.646,90 \\
\end{array}$ & $26.546 .804,10$ \\
\hline Monsen & 7.486 & 1497 & \begin{tabular}{|l|l}
$336.592,44$ \\
\end{tabular} & $59.054 .600,08$ & $698.677,64$ & $107.659 .675,16$ & $170.900,12$ & $33.835 .979,38$ & $134.847,22$ & $18.140 .843,99$ & $\begin{array}{l}22.711,51 \\
\end{array}$ & $29.441 .388,97$ \\
\hline $\begin{array}{l}\text { Morro Cabeça no } \\
\text { Tempo }\end{array}$ & 4.053 & 811 & $182.695,90$ & $32.053 .700,04$ & $378.271,50$ & $58.288 .092,90$ & $113.933,41$ & $22.557 .319,59$ & $89.898,14$ & $12.093 .896,00$ & $66.437,31$ & $15.939 .881,04$ \\
\hline $\begin{array}{l}\text { Morro do Chapéu do } \\
\text { Piauí }\end{array}$ & 6.574 & 1315 & $296.093,35$ & $51.949 .100,07$ & $613.559,55$ & $94.543 .775,65$ & $170.900,12$ & $33.835 .979,38$ & $134.847,22$ & $18.140 .843,99$ & $107.761,88$ & $25.854 .620,77$ \\
\hline Murici dos Portelas & 8.714 & 1743 & \begin{tabular}{|l|l|}
$392.391,19$ \\
\end{tabular} & $68.844 .400,09$ & $813.288,40$ & $125.320 .118,80$ & $2227.866,82$ & $45.114 .639,18$ & $179.796,29$ & $24.187 .791,99$ & $\begin{array}{l}142.841,05 \\
\end{array}$ & $\begin{array}{l}4.270 .940,88 \\
\end{array}$ \\
\hline & 7.248 & 1450 & $=$ & $7.159 .800,08$ & 676 & 104.236 & \begin{tabular}{|l|l|}
170.9 \\
\end{tabular} & $33.835 .979,38$ & $134.847,22$ & $18.140 .843,99$ & $118.810,18$ & $28.505 .368,32$ \\
\hline $\begin{array}{l}\text { Nossa Senhora de } \\
\text { Nazaré }\end{array}$ & 4.661 & 932 & 209 & $.700,05$ & $435.016,90$ & $2.025,90$ & 113 & 59 & 3,14 & .00 & 3,73 & $18.331 .059,84$ \\
\hline $\begin{array}{l}\text { Nossa Senhora dos } \\
\text { Remédios }\end{array}$ & 8.356 & 1671 & 37 & 0,09 & 82 & 2,98 & 6,82 & 18 & 29 & 99 & 66 & \\
\hline
\end{tabular}




\begin{tabular}{|c|c|c|c|c|c|c|c|c|c|c|c|c|}
\hline \multirow[b]{3}{*}{ Município } & \multirow[b]{3}{*}{$\begin{array}{c}\text { № de } \\
\text { habitantes } \\
\text { projetados } \\
(2012)\end{array}$} & \multirow[b]{3}{*}{$\begin{array}{c}\mathrm{N}^{\circ} \text { de } \\
\text { Famílias } \\
\text { (5 pessoas) }\end{array}$} & \multicolumn{4}{|c|}{ Solar Fotovoltaica } & \multicolumn{4}{|c|}{ Biomassa } & \multirow{2}{*}{\multicolumn{2}{|c|}{ Eólica }} \\
\hline & & & \multicolumn{2}{|c|}{ Minirredes } & \multicolumn{2}{|c|}{ Sistemas isolados } & \multicolumn{2}{|c|}{ Resíduos Agrícolas } & \multicolumn{2}{|c|}{ Óleo de dendê } & & \\
\hline & & & $\begin{array}{c}\text { Custo } \\
\text { evitado } \\
\text { (R\$) }\end{array}$ & \begin{tabular}{|c|} 
Custo do \\
empreendimento \\
considerando a \\
externalidade (R\$)
\end{tabular} & $\begin{array}{l}\text { Custo } \\
\text { evitado } \\
\text { (R\$) }\end{array}$ & $\begin{array}{c}\text { Custo do } \\
\text { empreendimento } \\
\text { considerando a } \\
\text { externalidade (R\$) }\end{array}$ & $\begin{array}{c}\text { Custo } \\
\text { evitado ( }(\mathrm{\$} \$)\end{array}$ & $\begin{array}{c}\text { Custo do } \\
\text { empreendimento } \\
\text { considerando a } \\
\text { externalidade (R\$) }\end{array}$ & $\begin{array}{l}\text { Custo } \\
\text { evitado } \\
\text { (R\$) }\end{array}$ & \begin{tabular}{|c|} 
Custo do \\
empreendimento \\
considerando a \\
externalidade $(\mathrm{R} \$)$
\end{tabular} & $\begin{array}{l}\text { Custo } \\
\text { evitado } \\
\text { (R\$) }\end{array}$ & $\begin{array}{c}\text { Custo do } \\
\text { empreendimento } \\
\text { considerando a } \\
\text { externalidade (R\$) }\end{array}$ \\
\hline Nova Santa Rita & 4.233 & 847 & $190.795,72$ & $33.474 .800,04$ & $395.071,13$ & $60.876 .757,27$ & $113.933,41$ & $22.557 .319,59$ & \begin{tabular}{|l|}
$89.898,14$ \\
\end{tabular} & $12.093 .896,00$ & $69.387,90$ & $16.647 .795,82$ \\
\hline Novo Oriente do Piauí & 6.459 & 1292 & $290.693,47$ & $51.001 .700,07$ & $602.826,46$ & $92.889 .906,74$ & $170.900,12$ & $33.835 .979,38$ & $134.847,22$ & $18.140 .843,99$ & $105.876,79$ & $25.402 .341,88$ \\
\hline Novo Santo Antônio & 3.329 & 666 & $149.396,64$ & $26.211 .400,04$ & $310.699,69$ & $47.875 .909,51$ & $113.933,41$ & $22.557 .319,59$ & $89.898,14$ & $12.093 .896,00$ & $54.569,41$ & $13.092 .490,50$ \\
\hline Olho d’Água do Piauí & 2.678 & 536 & $120.597,29$ & $21.158 .600,03$ & $249.941,05$ & $38.513 .573,35$ & $56.966,71$ & $11.278 .659,79$ & $44.949,07$ & $6.046 .948,00$ & $43.898,13$ & $10.532 .198,72$ \\
\hline Padre Marcos & 6.687 & 1337 & $300.593,25$ & $52.738 .600,07$ & $624.105,98$ & $96.168 .881,62$ & $170.900,12$ & $33.835 .979,38$ & $134.847,22$ & $18.140 .843,99$ & $109.614,19$ & $26.299 .033,93$ \\
\hline Paes Landim & 4.049 & 810 & $181.795,92$ & $31.895 .800,04$ & $377.898,18$ & $58.230 .567,02$ & $113.933,41$ & $22.557 .319,59$ & \begin{tabular}{|l|}
$89.898,14$ \\
\end{tabular} & $12.093 .896,00$ & $66.371,75$ & $15.924 .149,60$ \\
\hline Pajeú do Piauí & 3.434 & 687 & $154.796,52$ & $27.158 .800,04$ & $320.499,47$ & $49.385 .963,73$ & $113.933,41$ & $22.557 .319,59$ & $89.898,14$ & $12.093 .896,00$ & $56.290,58$ & $13.505 .440,78$ \\
\hline Palmeira do Piauí & 4.962 & 992 & $223.194,99$ & $39.159 .200,05$ & $463.109,60$ & $71.360 .848,00$ & $113.933,41$ & $22.557 .319,59$ & $89.898,14$ & $12.093 .896,00$ & $81.337,76$ & $19.514 .850,66$ \\
\hline Paquetá & 3.891 & 778 & $175.496,06$ & $30.790 .500,04$ & $363.151,84$ & $55.958 .294,96$ & $113.933,41$ & $22.557 .319,59$ & $89.898,14$ & $12.093 .896,00$ & $63.781,79$ & $15.302 .757,74$ \\
\hline $\begin{array}{c}\text { Passagem Franca do } \\
\text { Piauí } \\
\end{array}$ & 4.424 & 885 & $198.895,53$ & $34.895 .900,05$ & $412.897,39$ & $63.623 .617,81$ & $113.933,41$ & 22.557.319,59 & $89.898,14$ & $12.093 .896,00$ & $72.518,80$ & 17.398.972,05 \\
\hline Patos do Piauí & 6.178 & 1236 & $278.093,75$ & $48.791 .100,07$ & $576.600,38$ & $88.848 .714,02$ & $170.900,12$ & $33.835 .979,38$ & $134.847,22$ & $18.140 .843,99$ & $101.270,60$ & $24.297 .208,26$ \\
\hline Pavussu & 3.629 & 726 & $62.896,34$ & $28.579 .900,04$ & $338.699,06$ & $52.190 .350,14$ & $113.933,41$ & $22.557 .319,59$ & $89.898,14$ & $12.093 .896,00$ & $59.487,05$ & $14.272 .348,46$ \\
\hline Pedro Laurentino & 2.445 & 489 & $09.797,53$ & $19.263 .800,03$ & $228.194,88$ & $35.162 .691,12$ & $56.966,71$ & $11.278 .659,79$ & $44.949,07$ & $6.046 .948,00$ & $40.078,76$ & $9.615 .842,38$ \\
\hline Porto Alegre do Piauí & 2.606 & 521 & $116.997,37$ & $20.527 .000,03$ & $243.221,20$ & $37.478 .107,60$ & $56.966,71$ & $11.278 .659,79$ & $44.949,07$ & $6.046 .948,00$ & $42.717,90$ & $10.249 .032,81$ \\
\hline Prata do Piauí & 3.088 & 618 & $138.596,89$ & $24.316 .600,03$ & $288.206,86$ & $44.409 .975,54$ & $56.966,71$ & $11.278 .659,79$ & $44.949,07$ & $6.046 .948,00$ & $50.618,91$ & $12.144 .671,27$ \\
\hline Queimada Nova & 8.679 & 1736 & $390.591,23$ & $68.528 .600,09$ & $810.021,81$ & $124.816 .767,39$ & $227.866,82$ & $45.114 .639,18$ & $179.796,29$ & $24.187 .791,99$ & $142.267,32$ & $34.133 .290,79$ \\
\hline Redenção do Gurguéia & 8.494 & 1699 & $382.491,41$ & $67.107 .500,09$ & $792.755,53$ & $122.156 .195,67$ & $227.866,82$ & $45.114 .639,18$ & $179.796,29$ & $24.187 .791,99$ & $139.234,78$ & $33.405 .711,71$ \\
\hline Riacho Frio & 4.229 & 846 & $189.895,74$ & $33.316 .900,04$ & $394.697,80$ & $60.819 .231,40$ & $113.933,41$ & $22.557 .319,59$ & $89.898,14$ & $12.093 .896,00$ & $69.322,33$ & $16.632 .064,38$ \\
\hline Ribeira do Piauí & 4.321 & 4 & $194.395,63$ & $106.400,05$ & $403.284,28$ & $62.142 .326,52$ & $113.933,41$ & $22.557 .319,59$ & $89.898,14$ & $12.093 .896,00$ & $70.830,41$ & $16.993 .887,49$ \\
\hline Ribeiro Gonçalves & 7.015 & 1403 & $315.892,91$ & $55.422 .900,07$ & $654.718,63$ & $100.886 .003,37$ & $170.900,12$ & $33.835 .979,38$ & $134.847,22$ & $18.140 .843,99$ & $114.990,81$ & $27.589 .011,97$ \\
\hline Rio Grande do Piauí & 6.282 & 1256 & $282.593,65$ & $49.580 .600,07$ & $586.306,83$ & $90.344 .386,77$ & $170.900,12$ & $33.835 .979,38$ & $134.847,22$ & $18.140 .843,99$ & $102.975,38$ & $24.706 .225,69$ \\
\hline Santa Cruz do Piauí & 6.065 & 1213 & $272.693,88$ & $47.843 .700,06$ & $566.053,95$ & $87.223 .608,05$ & $170.900,12$ & $33.835 .979,38$ & $134.847,22$ & $18.140 .843,99$ & $99.418,29$ & $23.852 .795,09$ \\
\hline $\begin{array}{l}\text { Santa Cruz dos } \\
\text { Milagres }\end{array}$ & 3.864 & 773 & 696,10 & 00,04 & $360.631,90$ & $99.995,30$ & $113.933,41$ & 22.557.319,59 & $89.898,14$ & $12.093 .896,00$ & $63.339,20$ & $15.196 .570,53$ \\
\hline Santa Filomena & 6.106 & 1221 & $274.493,84$ & $48.159 .500,06$ & $569.880,53$ & $7.813 .248,27$ & $170.900,12$ & $33.835 .979,38$ & \begin{tabular}{|l|}
$134.847,22$ \\
\end{tabular} & $18.140 .843,99$ & $100.090,36$ & $24.014 .042,35$ \\
\hline Santa Luz & 5.624 & 1125 & $252.894,32$ & $44.369 .900,06$ & $524.894,88$ & $80.881 .380,32$ & $170.900,12$ & $33.835 .979,38$ & $134.847,22$ & $18.140 .843,99$ & $92.189,36$ & $22.118 .403,89$ \\
\hline Santa Rosa do Piauí & 5.145 & 1029 & $231.294,81$ & $40.580 .300,05$ & $480.189,22$ & 73.992.656,78 & $113.933,41$ & $22.557 .319,59$ & $89.898,14$ & $12.093 .896,00$ & $84.337,52$ & $20.234 .564,02$ \\
\hline Santana do Piauí & 4.489 & 898 & $201.595,47$ & $35.369 .600,05$ & $418.963,92$ & $64.558 .413,28$ & $113.933,41$ & 22.557.319,59 & $89.898,14$ & $12.093 .896,00$ & $73.584,28$ & $17.654 .607,94$ \\
\hline $\begin{array}{l}\text { Santo Antônio de } \\
\text { Lisboa }\end{array}$ & 6 & 227 & 2 & 7 & $572.680,47$ & 3 & 12 & 38 & 2 & 99 & 13 & 14 \\
\hline $\begin{array}{l}\text { Santo Antônio dos } \\
\text { Milagres }\end{array}$ & 2.087 & 417 & ,90 & 0,02 & 19 & 1 & 5 & 9,79 & 07 & 8,00 & ,38 & 8.207 \\
\hline Santo Inácio do Piauí & 3.679 & 736 & $165.596,28$ & $29.053 .600,04$ & $343.365,62$ & $52.909 .423,58$ & $113.933,41$ & $22.557 .319,59$ & $89.898,14$ & $12.093 .896,00$ & $60.306,66$ & $14.468 .991,45$ \\
\hline São Braz do Piaú & 4.332 & 866 & $195.295,61$ & $34.264 .300,05$ & $404.310,92$ & $62.300 .522,68$ & $113.933,41$ & $22.557 .319,59$ & $89.898,14$ & $12.093 .896,00$ & $71.010,72$ & 17.037.148,94 \\
\hline São Félix do Piauí & 2.925 & 585 & $131.397,05$ & $23.053 .400,03$ & $272.993,87$ & $42.065 .796,13$ & $56.966,71$ & $11.278 .659,79$ & $44.949,07$ & $6.046 .948,00$ & $47.946,99$ & $11.503 .615,11$ \\
\hline
\end{tabular}




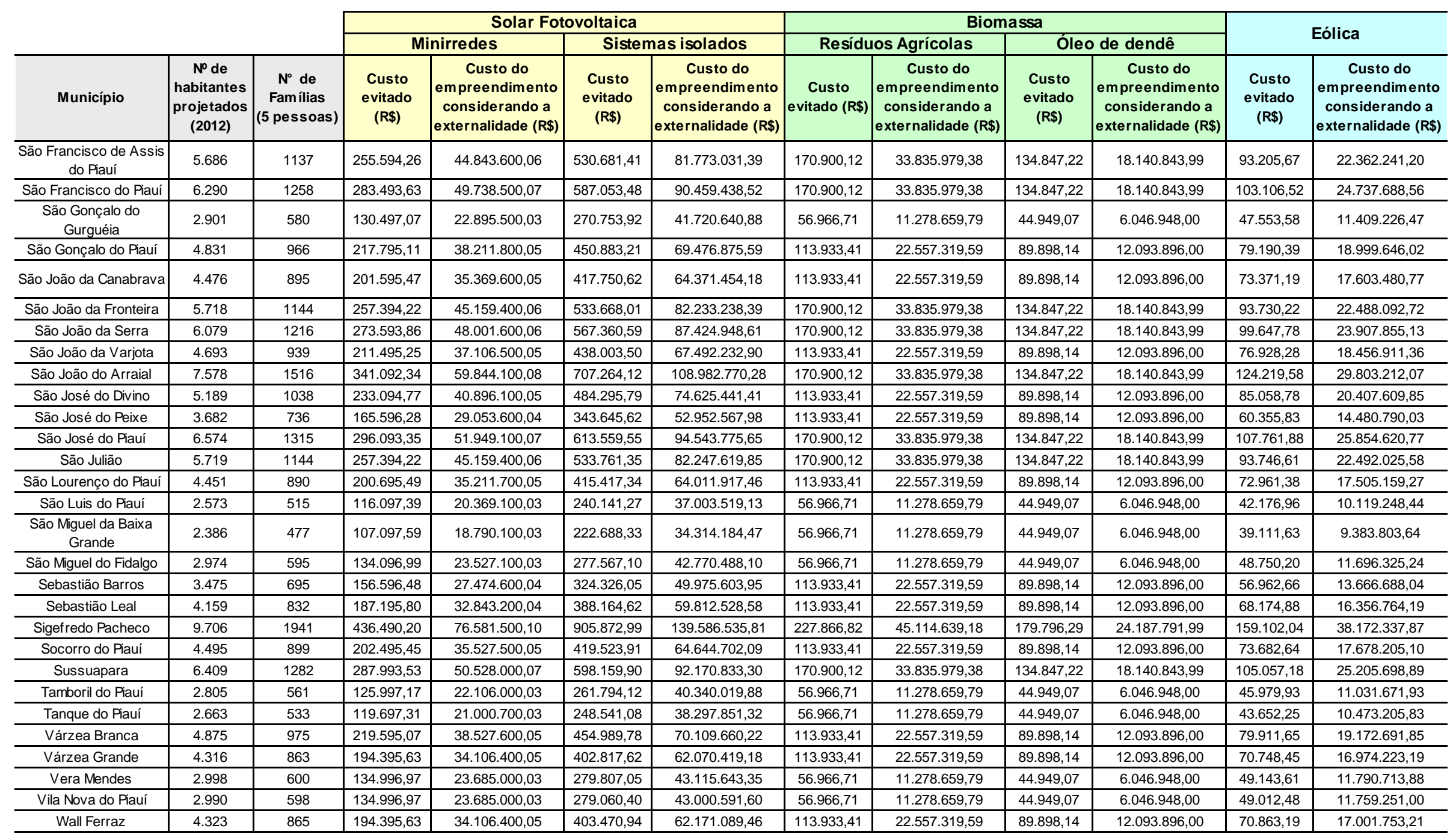




\section{B.8 - Consolidação dos resultados para o Rio Grande do Norte}

\begin{tabular}{|c|c|c|c|c|c|c|c|c|c|c|c|c|}
\hline \multirow[b]{3}{*}{ Município } & \multirow[b]{3}{*}{$\begin{array}{c}\text { № de } \\
\text { habitantes } \\
\text { projetados } \\
(2012)\end{array}$} & \multirow[b]{3}{*}{$\begin{array}{c}\mathrm{N}^{\circ} \text { de } \\
\text { Fam ílias } \\
\text { (5 pessoas) }\end{array}$} & \multicolumn{4}{|c|}{ Solar Fotovoltaica } & \multicolumn{4}{|c|}{ Biomassa } & \multirow{2}{*}{\multicolumn{2}{|c|}{ Eólica }} \\
\hline & & & \multicolumn{2}{|c|}{ Minirredes } & \multicolumn{2}{|c|}{ Sistemas isolados } & \multicolumn{2}{|c|}{ Resíduos Agrícolas } & \multicolumn{2}{|c|}{ Óleo de dendê } & & \\
\hline & & & $\begin{array}{l}\text { Custo } \\
\text { evitado } \\
\text { (R\$) }\end{array}$ & \begin{tabular}{|c|} 
Custo do \\
empreendimento \\
considerando a \\
externalidade $(\mathrm{R} \$)$
\end{tabular} & $\begin{array}{c}\text { Custo } \\
\text { evitado } \\
\text { (R\$) }\end{array}$ & $\begin{array}{c}\text { Custo do } \\
\text { empreendimento } \\
\text { considerando a } \\
\text { externalidade ( } R \$)\end{array}$ & $\begin{array}{c}\text { Custo } \\
\text { evitado }(R \$)\end{array}$ & $\begin{array}{c}\text { Custo do } \\
\text { empreendimento } \\
\text { considerando a } \\
\text { externalidade ( } R \$)\end{array}$ & $\begin{array}{c}\text { Custo } \\
\text { evitado } \\
\text { (R\$) }\end{array}$ & \begin{tabular}{|c|} 
Custo do \\
empreendimento \\
considerando a \\
externalidade (R\$)
\end{tabular} & $\begin{array}{c}\text { Custo } \\
\text { evitado } \\
\text { (R\$) }\end{array}$ & $\begin{array}{c}\text { Custo do } \\
\text { empreendimento } \\
\text { considerando a } \\
\text { externalidade ( } R \$ \text { ) }\end{array}$ \\
\hline Água Nova & 3.026 & 605 & $135.896,95$ & $23.842 .900,03$ & $282.420,32$ & $43.518 .324,48$ & $56.966,71$ & $11.278 .659,79$ & \begin{tabular}{|l|}
$44.949,07$ \\
\end{tabular} & $6.046 .948,00$ & $49.602,59$ & $11.900 .833,96$ \\
\hline Almino Afonso & 4.823 & 965 & $216.895,13$ & $8.053 .900,05$ & $450.136,56$ & $69.361 .823,84$ & $113.933,41$ & $22.557 .319,59$ & \begin{tabular}{|l|}
$89.898,14$ \\
\end{tabular} & $12.093 .896,00$ & $79.059,26$ & $18.968 .183,14$ \\
\hline Antônio Martins & 6.930 & 1386 & $312.292,99$ & $54.791 .300,07$ & $646.785,47$ & $99.663 .578,53$ & $170.900,12$ & $33.835 .979,38$ & $134.847,22$ & $18.140 .843,99$ & $113.597,48$ & $27.254 .718,88$ \\
\hline Augusto Severo & 9.330 & 1866 & $420.290,56$ & $73.739 .300,10$ & $870.780,44$ & $134.179 .103,56$ & $227.866,82$ & $45.114 .639,18$ & $179.796,29$ & $24.187 .791,99$ & $152.938,60$ & $36.693 .582,56$ \\
\hline Baía Formosa & 8.687 & 1737 & $390.591,23$ & $68.528 .600,09$ & $810.768,46$ & $124.931 .819,14$ & $227.866,82$ & $45.114 .639,18$ & $179.796,29$ & $24.187 .791,99$ & $142.398,46$ & $34.164 .753,67$ \\
\hline Barcelona & 3.944 & 789 & $177.296,02$ & $31.106 .300,04$ & $368.098,40$ & $56.720 .512,80$ & $113.933,41$ & $22.557 .319,59$ & \begin{tabular}{|l|}
$89.898,14$ \\
\end{tabular} & $12.093 .896,00$ & $64.650,57$ & $15.511 .199,32$ \\
\hline Bento Fernandes & 175 & 1035 & $233.094,77$ & $0.896 .100,05$ & $482.989,15$ & $74.424 .100,85$ & $113.933,41$ & 22.557.319,59 & $89.898,14$ & $12.093 .896,00$ & $84.829,29$ & $20.352 .549,81$ \\
\hline Bodó & 373 & 475 & $107.097,59$ & $8.790 .100,03$ & $221.475,03$ & $34.127 .225,37$ & $56.966,71$ & $11.278 .659,79$ & \begin{tabular}{|l|}
$44.949,07$ \\
\end{tabular} & $6.046 .948,00$ & $38.898,53$ & $9.332 .676,46$ \\
\hline Bom Jesus & 566 & 1913 & $430.190,34$ & $5.476 .200,10$ & $892.806,62$ & $137.573 .130,18$ & $227.866,82$ & $45.114 .639,18$ & $179.796,29$ & $24.187 .791,99$ & $156.807,14$ & $37.621 .737,49$ \\
\hline Caiçara do Norte & & 120 & $1.793,90$ & $685.800,06$ & \begin{tabular}{|l|}
$564.000,67$ \\
\end{tabular} & 86.907. & $170.900,12$ & $835.979,38$ & \begin{tabular}{|l|}
$134.847,22$ \\
\end{tabular} & $18.140 .843,99$ & $99.057,66$ & 72,18 \\
\hline $\begin{array}{c}\text { Caiçara do Rio do } \\
\text { Vento }\end{array}$ & 3.375 & 675 & 96,58 & 26.6 & 2,93 & 7 & 1 & 19,59 & 4 & $12.093 .896,00$ & $5.323,45$ & 402,05 \\
\hline Carnaúba dos Dantas & 559 & 512 & $0.192,36$ & $.686 .200,08$ & $705.490,82$ & $108.709 .522,38$ & $70.900,12$ & $33.835 .979,38$ & $134.847,22$ & $18.140 .843,99$ & $123.908,13$ & $9.728 .487,74$ \\
\hline Coronel Ezequiel & 405 & 1081 & $242.994,54$ & $2.633 .000,06$ & $504.455,34$ & $77.731 .838,66$ & $113.933,41$ & $22.557 .319,59$ & \begin{tabular}{|l|}
$89.898,14$ \\
\end{tabular} & $12.093 .896,00$ & $88.599,48$ & $1.257 .107,58$ \\
\hline Coronel João Pessoa & 4.783 & 957 & $215.095,17$ & $37.738 .100,05$ & $446.403,31$ & $68.786 .565,09$ & $113.933,41$ & $22.557 .319,59$ & \begin{tabular}{|l|}
$89.898,14$ \\
\end{tabular} & $12.093 .896,00$ & $78.403,57$ & $18.810 .868,74$ \\
\hline Cruzeta & 7.942 & 1588 & $357.291,98$ & $62.686 .300,08$ & $741.236,69$ & $114.217 .624,91$ & $227.866,82$ & $45.114 .639,18$ & $179.796,29$ & $24.187 .791,99$ & $130.186,32$ & $31.234 .773,06$ \\
\hline Doutor Severiano & 6.954 & 1391 & $313.192,97$ & $54.949 .200,07$ & $649.025,42$ & $100.008 .733,78$ & $170.900,12$ & $33.835 .979,38$ & $134.847,22$ & $18.140 .843,99$ & $113.990,89$ & $27.349 .107,52$ \\
\hline Encanto & 297 & 59 & $238.494,64$ & $.843 .500,06$ & $494.375,56$ & $76.178 .640,04$ & $113.933,41$ & $22.557 .319,59$ & $89.898,14$ & $12.093 .896,00$ & $86.829,13$ & $0.832 .358,72$ \\
\hline Equador & 46 & 1169 & $62.794,10$ & $.106 .800,06$ & $545.614,41$ & $84.074 .066,39$ & $170.900,12$ & $33.835 .979,38$ & \begin{tabular}{|l|}
$134.847,22$ \\
\end{tabular} & $18.140 .843,99$ & $95.828,41$ & $1.498,78$ \\
\hline Felipe Guerra & 765 & 1153 & $259.194,18$ & $5.475 .200,06$ & $538.054,58$ & $82.909 .167,42$ & $170.900,12$ & $33.835 .979,38$ & $134.847,22$ & $18.140 .843,99$ & $94.500,65$ & $22.672 .937,13$ \\
\hline Fernando Pedroza & 2.885 & 577 & $29.597,09$ & $22.737 .600,03$ & $269.260,62$ & $1.490 .537,38$ & $56.966,71$ & $11.278 .659,79$ & \begin{tabular}{|l|}
$44.949,07$ \\
\end{tabular} & $6.046 .948,00$ & $47.291,30$ & $11.346 .300,72$ \\
\hline Florânia & 8.957 & 1791 & $403.190,94$ & $70.739 .200,10$ & $835.967,89$ & 128.814.815,71 & $227.866,82$ & $45.114 .639,18$ & \begin{tabular}{|l|}
$179.796,29$ \\
\end{tabular} & $24.187 .791,99$ & $146.824,33$ & $35.226 .625,83$ \\
\hline Francisco Dantas & 2.852 & 570 & $128.697,11$ & $22.579 .700,03$ & $266.180,69$ & $41.015 .948,91$ & $56.966,71$ & $11.278 .659,79$ & \begin{tabular}{|l|}
$44.949,07$ \\
\end{tabular} & $6.046 .948,00$ & $46.750,36$ & $11.216 .516,34$ \\
\hline Frutuoso Gomes & 4.181 & 836 & $188.095,78$ & $33.001 .100,04$ & $390.217,90$ & $60.128 .920,90$ & $113.933,41$ & $22.557 .319,59$ & $89.898,14$ & $12.093 .896,00$ & $68.535,51$ & $16.443 .287,10$ \\
\hline Galinhos & 2.284 & 457 & $102.597,70$ & $18.000 .600,02$ & $213.168,55$ & $32.847 .274,65$ & $56.966,71$ & $11.278 .659,79$ & \begin{tabular}{|l|}
$44.949,07$ \\
\end{tabular} & $6.046 .948,00$ & $37.439,63$ & $8.982 .651,94$ \\
\hline Grossos & 9.566 & 1913 & $430.190,34$ & $75.476 .200,10$ & $892.806,62$ & $137.573 .130,18$ & $227.866,82$ & $45.114 .639,18$ & $179.796,29$ & $24.187 .791,99$ & $156.807,14$ & $37.621 .737,49$ \\
\hline Ipueira & 2.104 & 421 & $94.497,88$ & $16.579 .500,02$ & $196.368,92$ & $30.258 .610,28$ & $56.966,71$ & $11.278 .659,79$ & $44.949,07$ & $6.046 .948,00$ & $34.489,05$ & $8.274 .737,16$ \\
\hline Itajá & 7.036 & 1407 & $316.792,89$ & $55.580 .800,07$ & $656.678,59$ & $101.188 .014,21$ & $170.900,12$ & $33.835 .979,38$ & $134.847,22$ & $18.140 .843,99$ & $115.335,05$ & $27.671 .602,03$ \\
\hline Itau & 5.609 & 1122 & $251.994,34$ & $4.212 .000,06$ & $523.494,91$ & $.665 .658,29$ & $170.900,12$ & $33.835 .979,38$ & $134.847,22$ & $18.140 .843,99$ & $91.943,47$ & $22.059 .410,99$ \\
\hline Jaçanã & & & . 191,75 & $423.200,09$ & $760.649,58$ & $117.208 .970,42$ & $227.866,82$ & $.114 .639,18$ & $179.796,29$ & 24.187.791,99 & $133.595,88$ & 32.052.807,92 \\
\hline Jandaíra & & 1368 & $307.793,09$ & $1.800,07$ & $638.199,00$ & 483,40 & $170.900,12$ & 979,38 & \begin{tabular}{|l|}
$134.847,22$ \\
\end{tabular} & $18.140 .843,99$ & $112.089,40$ & $26.892 .895,77$ \\
\hline & 5.307 & 1061 & $8.494,64$ & $41.843 .500,06$ & $495.308,88$ & 76.32 & $113.933,41$ & $22.557 .319,59$ & 3,14 & $12.093 .896,00$ & $86.993,05$ & $20.871 .687,31$ \\
\hline
\end{tabular}




\begin{tabular}{|c|c|c|c|c|c|c|c|c|c|c|c|c|}
\hline & \multirow{2}{*}{\multicolumn{4}{|c|}{ Solar Fotovoltaica }} & \multirow{2}{*}{\multicolumn{4}{|c|}{ Biomassa }} & \multirow{2}{*}{\multicolumn{2}{|c|}{ Eólica }} \\
\hline & & & & & & & & & & & & \\
\hline Municipio & \begin{tabular}{|c|} 
№ de \\
habitantes \\
projetados \\
(2012)
\end{tabular} & $\begin{array}{c}N^{\circ} \text { de } \\
\text { Famílias } \\
\text { (5 pessoas) }\end{array}$ & $\begin{array}{l}\text { Custo } \\
\text { evitado } \\
\text { (R\$) }\end{array}$ & \begin{tabular}{|c|} 
Custo do \\
empreendimento \\
considerando a \\
externalidade (R\$)
\end{tabular} & $\begin{array}{l}\text { Custo } \\
\text { evitado } \\
\text { (R\$) }\end{array}$ & \begin{tabular}{|c|} 
Custo do \\
empreendimento \\
considerando a \\
externalidade (R\$)
\end{tabular} & $\begin{array}{c}\text { Custo } \\
\text { evitado (R\$) }\end{array}$ & $\begin{array}{c}\text { Custo do } \\
\text { empreendimento } \\
\text { considerando a } \\
\text { externalidade (R\$) }\end{array}$ & $\begin{array}{l}\text { Custo } \\
\text { evitado } \\
\text { (R\$) }\end{array}$ & \begin{tabular}{|c|} 
Custo do \\
empreendimento \\
considerando a \\
externalidade (R\$) \\
\end{tabular} & $\begin{array}{l}\text { Custo } \\
\text { evitado } \\
\text { (R\$) }\end{array}$ & $\begin{array}{c}\text { Custo do } \\
\text { em preendimento } \\
\text { considerando a } \\
\text { externalidade (R\$) } \\
\end{array}$ \\
\hline Januário Cicco & 9.211 & 1842 & \begin{tabular}{|l|l|l}
$414.890,68$ \\
\end{tabular} & $72.791 .900,10$ & $859.674,03$ & $132.467 .708,77$ & \begin{tabular}{|l|}
$227.866,82$ \\
\end{tabular} & $45.114 .639,18$ & $179.796,29$ & $24.187 .791,99$ & \begin{tabular}{|l|l|}
$150.987,94$ \\
\end{tabular} & $36.225 .572,24$ \\
\hline Japi & 5.401 & 1080 & $242.994,54$ & $42.633 .000,06$ & $504.082,01$ & $\begin{array}{l}77.674 .312,79 \\
\end{array}$ & \begin{tabular}{|l|}
$113.933,41$ \\
\end{tabular} & $22.557 .319,59$ & $89.898,14$ & $12.093 .896,00$ & $88.533,91$ & $21.241 .376,14$ \\
\hline Jardim de Angicos & 2.598 & 520 & \begin{tabular}{|l|l|}
$116.997,37$ \\
\end{tabular} & $20.527 .000,03$ & $242.474,55$ & $37.363 .055,85$ & \begin{tabular}{|l|}
$56.966,71$ \\
\end{tabular} & $11.278 .659,79$ & $44.949,07$ & $6.046 .948,00$ & \begin{tabular}{|l|l|}
$42.586,76$ \\
\end{tabular} & $10.217 .569,93$ \\
\hline João Dias & 2.602 & 520 & \begin{tabular}{|l|l|}
$116.997,37$ \\
\end{tabular} & $20.527 .000,03$ & $242.847,88$ & $37.420 .581,72$ & \begin{tabular}{|l|}
$56.966,71$ \\
\end{tabular} & $11.278 .659,79$ & $44.949,07$ & $6.046 .948,00$ & \begin{tabular}{|l|}
$42.652,33$ \\
4
\end{tabular} & $\begin{array}{l}0.233 .301,37 \\
\end{array}$ \\
\hline José da Penha & 5.862 & 1172 & \begin{tabular}{|l|l|}
$263.694,08$ \\
\end{tabular} & $46.264 .700,06$ & $547.107,71$ & $84.304 .169,89$ & \begin{tabular}{|l|}
$170.900,12$ \\
\end{tabular} & $33.835 .979,38$ & $134.847,22$ & $18.140 .843,99$ & $\begin{array}{ll}96.090,68 \\
\end{array}$ & $23.054 .424,54$ \\
\hline Jundiá & 3.635 & 727 & $163.796,32$ & & $339.259,05$ & & \begin{tabular}{|l|}
$113.933,41$ \\
\end{tabular} & & $89.898,14$ & & & \\
\hline Lagoa de Pedras & 7.079 & 1416 & \begin{tabular}{|l|l|}
$318.592,84$ \\
\end{tabular} & 55.8 & $660.691,83$ & $101 . \varepsilon$ & \begin{tabular}{|l|}
$170.900,12$ \\
\end{tabular} & $33.835 .979,38$ & $134.847,22$ & $18.140 .843,99$ & \begin{tabular}{|l|l|}
$116.039,91$ \\
\end{tabular} & 27.8 \\
\hline Lagoa de Velhos & 2.671 & 534 & \begin{tabular}{|l|l|}
$120.597,29$ \\
\end{tabular} & $21.158 .600,03$ & $249.287,73$ & $38.412 .903,07$ & \begin{tabular}{|c|}
$56.966,71$ \\
\end{tabular} & $11.278 .659,79$ & $44.949,07$ & $6.046 .948,00$ & $443.783,39$ & $10.504 .668,71$ \\
\hline Lagoc & & & 61 & & $589.666,76$ & & \begin{tabular}{|l|}
$170.900,12$ \\
\end{tabular} & & $134.847,22$ & & & \\
\hline Lagoa Salgada & 7.679 & 1536 & $345.592,24$ & $60.633 .600,08$ & $716.690,57$ & $110.435 .298,63$ & \begin{tabular}{|l|}
$227.866,82$ \\
\end{tabular} & $\begin{array}{l}45.114 .639,18 \\
\end{array}$ & $179.796,29$ & $24.187 .791,99$ & \begin{tabular}{|l|l|}
$125.875,19$ \\
\end{tabular} & $30.200 .430,92$ \\
\hline Lajes Pintadas & 4.625 & 925 & $207.895,33$ & $36.474 .900,05$ & $431.656,97$ & $66.514 .293,03$ & \begin{tabular}{|l|}
$113.933,41$ \\
\end{tabular} & $22.557 .319,59$ & $89.898,14$ & $12.093 .896,00$ & $75.813,61$ & $18.189 .476,89$ \\
\hline & & & & & $344.952,25$ & & \begin{tabular}{|l|}
$113.933,41$ \\
\end{tabular} & & 89.8 & & & \\
\hline Luís Gomes & 9.679 & 1936 & \begin{tabular}{|l|l|}
$435.590,22$ \\
\end{tabular} & $76.423 .600,10$ & $903.353,05$ & $139.198 .236,15$ & \begin{tabular}{|l|}
$227.866,82$ \\
\end{tabular} & $45.114 .639,18$ & $179.796,29$ & $24.187 .791,99$ & $158.659,45$ & $38.066 .150,65$ \\
\hline Major Sales & 3.625 & 725 & \begin{tabular}{|l|l|}
$162.896,34$ \\
\end{tabular} & $28.579 .900,04$ & $338.325,74$ & $52.132 .824,26$ & \begin{tabular}{|l|}
$113.933,41$ \\
\end{tabular} & $22.557 .319,59$ & $89.898,14$ & $12.093 .896,00$ & $59.421,48$ & $14.256 .617,02$ \\
\hline Marcelino Vieira & & & \begin{tabular}{|l|l|l|}
$370.791,67$ \\
\end{tabular} & & $769.889,38$ & & \begin{tabular}{|l|}
$227.866,82$ \\
\end{tabular} & & 179.7 & & & \\
\hline Martins & 8.293 & 1659 & \begin{tabular}{|l}
$373.491,61$ \\
\end{tabular} & $65.528 .500,09$ & $773.995,95$ & $119.265 .520,45$ & \begin{tabular}{|l|}
$227.866,82$ \\
\end{tabular} & $45.114 .639,18$ & $179.796,29$ & $24.187 .791,99$ & $135.939,96$ & $32.615 .206,88$ \\
\hline Messias Targino & 4.259 & 852 & \begin{tabular}{|l|l|}
$191.695,69$ \\
\end{tabular} & $33.632 .700,05$ & $397.497,74$ & $61.250 .675,46$ & \begin{tabular}{|l|}
$113.933,41$ \\
\end{tabular} & $22.557 .319,59$ & $89.898,14$ & $12.093 .896,00$ & $699.814,09$ & $16.750 .050,17$ \\
\hline Monte das Gameleiras & 2.219 & 444 & \begin{tabular}{|l|}
$99.897,76$ \\
\end{tabular} & $17.526 .900,02$ & $207.102,02$ & $31.912 .479,18$ & \begin{tabular}{|l|}
$56.966,71$ \\
\end{tabular} & $11.278 .659,79$ & $444.949,07$ & $6.046 .948,00$ & \begin{tabular}{ll|}
$36.374,14$ \\
\end{tabular} & $8.727 .016,05$ \\
\hline Olho-d’ Água do Borges & 4.270 & 854 & 192.595,67 & $33.790 .600,05$ & $398.524,38$ & $61.408 .871,62$ & 113.933,41 & 22.557.319,59 & $89.898,14$ & $12.093 .896,00$ & $69.994,41$ & $16.793 .311,63$ \\
\hline Ouro Branco & 4.704 & 941 & $211.495,25$ & $37.106 .500,05$ & $439.030,14$ & $67.650 .429,06$ & \begin{tabular}{|l|}
$113.933,41$ \\
\end{tabular} & $22.557 .319,59$ & $89.898,14$ & $12.093 .896,00$ & $77.108,59$ & $18.500 .172,82$ \\
\hline Paraná & & 800 & $9.995,96$ & $580.000,04$ & $373.418,28$ & $57.540 .256,52$ & \begin{tabular}{|l|}
$113.933,41$ \\
\end{tabular} & $22.557 .319,59$ & $89.898,14$ & $12.093 .896,00$ & $65.584,92$ & $15.735 .372,33$ \\
\hline Paraú & 3.824 & 765 & $177.896,14$ & $0.158 .900,04$ & $356.898,65$ & $4.736,55$ & \begin{tabular}{|l|}
$113.933,41$ \\
\end{tabular} & $22.557 .319,59$ & $89.898,14$ & $12.093 .896,00$ & $62.683,52$ & $15.039 .256,13$ \\
\hline Parazinho & 4.924 & 985 & $1.395,03$ & $38.843 .400,05$ & $459.563,01$ & $70.814 .352,19$ & $113.933,41$ & $22.557 .319,59$ & $89.898,14$ & $12.093 .896,00$ & \begin{tabular}{ll|}
$80.714,86$ \\
\end{tabular} & $19.365 .401,99$ \\
\hline Passagem & & & $131.397,05$ & $23.053 .400,03$ & $272.993,87$ & $5.796,13$ & \begin{tabular}{|l|}
$56.966,71$ \\
\end{tabular} & $11.278 .659,79$ & $44.949,07$ & $6.046 .948,00$ & \begin{tabular}{ll|}
$47.946,99$ \\
\end{tabular} & $11.503 .615,11$ \\
\hline Pedra Gra & & 68 & $154.796,52$ & 04 & $321.712,77$ & & $113.933,41$ & 319,59 & $.898,14$ & 96,00 & $56.503,68$ & $13.556 .567,96$ \\
\hline Pedra Preta & 2.552 & 5 & $5.197,41$ & $.211 .200,03$ & $238.181,32$ & $36.701 .508,28$ & $56.966,71$ & $11.278 .659,79$ & $44.949,07$ & $6.046 .948,00$ & $41.832,72$ & $10.036 .658,38$ \\
\hline Pedro Avelino & & 1409 & $316.792,89$ & $55.580 .800,07$ & $657.518,57$ & $101.317 .447,43$ & \begin{tabular}{|l|}
$170.900,12$ \\
\end{tabular} & $33.835 .979,38$ & $134.847,22$ & $18.140 .843,99$ & 115.482,58 & $27.706 .997,76$ \\
\hline Pilōes & 3.522 & 704 & $158.396,44$ & $7.790 .400,04$ & $328.712,62$ & $50.651 .532,98$ & \begin{tabular}{|l|}
$113.933,41$ \\
\end{tabular} & $22.557 .319,59$ & $89.898,14$ & $12.093 .896,00$ & $57.733,09$ & $13.851 .532,45$ \\
\hline Portalegre & 7.407 & 1481 & $332.992,52$ & $58.423 .000,08$ & $691.304,47$ & $106.523 .539,13$ & \begin{tabular}{|l|}
$170.900,12$ \\
\end{tabular} & $33.835 .979,38$ & $134.847,22$ & $18.140 .843,99$ & $121.416,53$ & $29.130 .693,04$ \\
\hline Porto do Mangu & 5.392 & 1078 & $242.994,54$ & $42.633 .000,06$ & $503.242,03$ & $77.544 .879,57$ & \begin{tabular}{|l|}
$113.933,41$ \\
\end{tabular} & $22.557 .319,59$ & $89.898,14$ & $12.093 .896,00$ & $88.386,38$ & $21.205 .980,40$ \\
\hline residente Jusc & & 18 & $6.790,86$ & & $843.247,73$ & 70,27 & \begin{tabular}{|l|l|}
$227.866,82$ \\
\end{tabular} & 39,18 & $179.796,29$ & & \begin{tabular}{|l|l|}
$148.102,92$ \\
\end{tabular} & $35.533 .388,90$ \\
\hline Pureza & 8. & 1729 & \begin{tabular}{|l|l|}
$388.791,27$ \\
\end{tabular} & $68.212 .800,09$ & 80 & $124.327 .797,45$ & \begin{tabular}{|l|}
$227.866,82$ \\
\end{tabular} & $45.114 .639,18$ & $179.796,29$ & $24.187 .791,99$ & $141.709,99$ & $33.999 .573,55$ \\
\hline Rafael Fernandes & 4.760 & 952 & $214.195,19$ & $37.580 .200,05$ & $444.256,69$ & $68.455 .791,31$ & \begin{tabular}{|l|}
$113.933,41$ \\
\end{tabular} & $22.557 .319,59$ & $89.898,14$ & $12.093 .896,00$ & $78.026,55$ & $18.720 .412,97$ \\
\hline & 3.080 & 616 & $8.596,89$ & 0,03 & & 3,79 & & & 4494907 & 948,00 & $50.487,77$ & $12.113 .208,39$ \\
\hline & 3.241 & 648 & 796,73 & $579.800,03$ & $302.486,54$ & $46.610 .340,26$ & $56.966,71$ & $11.278 .659,79$ & $44.949,07$ & $6.046 .948,00$ & $53.126,90$ & $12.746 .398,83$ \\
\hline
\end{tabular}




\begin{tabular}{|c|c|c|c|c|c|c|c|c|c|c|c|c|}
\hline & & & \multirow{2}{*}{\multicolumn{4}{|c|}{ Solar Fotovoltaica }} & \multirow{2}{*}{\multicolumn{4}{|c|}{ Biomassa }} & \multirow{3}{*}{\multicolumn{2}{|c|}{ Eólica }} \\
\hline & & & & & & & & & & & & \\
\hline & & & \multicolumn{2}{|c|}{ Minirredes } & \multicolumn{2}{|c|}{ Sistemas isolados } & \multicolumn{2}{|c|}{ Resíduos Agrícolas } & \multicolumn{2}{|c|}{ Óleo de dendê } & & \\
\hline Município & $\begin{array}{c}\text { № de } \\
\text { habitantes } \\
\text { projetados } \\
(2012)\end{array}$ & $\begin{array}{c}\mathrm{N}^{\circ} \text { de } \\
\text { Fam ílias } \\
\text { (5 pessoas) }\end{array}$ & $\begin{array}{l}\text { Custo } \\
\text { evitado } \\
\text { (R\$) }\end{array}$ & \begin{tabular}{|c|} 
Custo do \\
empreendimento \\
considerando a \\
externalidade (R\$)
\end{tabular} & $\begin{array}{c}\text { Custo } \\
\text { evitado } \\
\text { (R\$) }\end{array}$ & $\begin{array}{c}\text { Custo do } \\
\text { empreendimento } \\
\text { considerando a } \\
\text { externalidade ( } \mathrm{R} \$ \text { ) }\end{array}$ & $\begin{array}{c}\text { Custo } \\
\text { evitado (R\$) }\end{array}$ & $\begin{array}{c}\text { Custo do } \\
\text { empreendimento } \\
\text { considerando a } \\
\text { externalidade ( } \mathrm{R} \$ \text { ) }\end{array}$ & $\begin{array}{c}\text { Custo } \\
\text { evitado } \\
\text { (R\$) }\end{array}$ & \begin{tabular}{|c|} 
Custo do \\
empreendimento \\
considerando a \\
externalidade ( $R \$)$
\end{tabular} & $\begin{array}{c}\text { Custo } \\
\text { evitado } \\
\text { (R\$) }\end{array}$ & $\begin{array}{c}\text { Custo do } \\
\text { empreendimento } \\
\text { considerando a } \\
\text { externalidade (R\$) }\end{array}$ \\
\hline Riacho de Santana & 4.150 & 830 & $187.195,80$ & $32.843 .200,04$ & $387.324,63$ & $59.683 .095,37$ & $3.933,41$ & $22.557 .319,59$ & $89.898,14$ & $12.093 .896,00$ & $68.027,35$ & $16.321 .368,45$ \\
\hline Riachuelo & 7.265 & 1453 & $326.692,66$ & $57.317 .700,08$ & $678.051,44$ & $104.481 .370,56$ & $170.900,12$ & $33.835 .979,38$ & $134.847,22$ & $18.140 .843,99$ & $119.088,85$ & 28.572.226,93 \\
\hline Rodolfo Fernandes & 4.411 & 882 & $198.895,53$ & $34.895 .900,05$ & $411.684,09$ & $63.436 .658,71$ & $113.933,41$ & $22.557 .319,59$ & $89.898,14$ & $12.093 .896,00$ & $72.305,70$ & $17.347 .844,87$ \\
\hline Ruy Barbosa & 3.582 & 716 & $161.096,38$ & $28.264 .100,04$ & $334.312,49$ & $51.514 .421,11$ & $113.933,41$ & $22.557 .319,59$ & $89.898,14$ & $12.093 .896,00$ & $58.716,62$ & $14.087 .504,04$ \\
\hline Santa Maria & 911 & 82 & $221.395,03$ & $8.843 .400,05$ & $458.349,71$ & $70.627 .393,09$ & $113.933,41$ & $22.557 .319,59$ & $89.898,14$ & $12.093 .896,00$ & $80.501,76$ & $19.314 .274,81$ \\
\hline Santana do Seridó & 549 & 10 & $114.297,43$ & $20.053 .300,03$ & $237.901,32$ & $36.658 .363,88$ & $56.966,71$ & $11.278 .659,79$ & $44.949,07$ & $6.046 .948,00$ & $41.783,55$ & $10.024 .859,80$ \\
\hline São Bento do Norte & 915 & 83 & $131.397,05$ & $23.053 .400,03$ & $272.060,56$ & $41.921 .981,44$ & $56.966,71$ & $11.278 .659,79$ & $44.949,07$ & $6.046 .948,00$ & $47.783,07$ & 86,51 \\
\hline São Bento do Trairí & 005 & 801 & $179.995,96$ & $31.580 .000,04$ & $373.791,61$ & $57.597 .782,39$ & $113.933,41$ & $22.557 .319,59$ & $89.898,14$ & $12.093 .896,00$ & $65.650,49$ & $15.751 .103,77$ \\
\hline São Fernando & 27 & 685 & $153.896,54$ & $27.000 .900,04$ & $319.846,15$ & $49.285 .293,45$ & $113.933,41$ & $22.557 .319,59$ & $89.898,14$ & $12.093 .896,00$ & $56.175,84$ & $13.477 .910,76$ \\
\hline $\begin{array}{c}\text { São Francisco do } \\
\text { Oeste }\end{array}$ & 3.934 & 787 & $177.296,02$ & $31.106 .300,04$ & $367.165,09$ & $56.576 .698,11$ & $113.933,41$ & 22.557.319,59 & $89.898,14$ & $12.093 .896,00$ & $64.486,65$ & $15.471 .870,72$ \\
\hline São João do Sabugi & 6 & 91 & $8.193,98$ & $.054 .200,06$ & $555.880,85$ & $.656 .027,95$ & $0.900,12$ & $33.835 .979,38$ & $134.847,22$ & $8.140 .843,99$ & $97.631,54$ & $23.424 .113,37$ \\
\hline São José do Seridó & 4.300 & 860 & $193.495,65$ & $33.948 .500,05$ & $401.324,32$ & $61.840 .315,68$ & $113.933,41$ & $22.557 .319,59$ & $89.898,14$ & $12.093 .896,00$ & $70.486,17$ & $16.911 .297,43$ \\
\hline São Pedro & 6.154 & 1231 & $277.193,77$ & $48.633 .200,07$ & $574.360,43$ & $88.503 .558,77$ & $170.900,12$ & $33.835 .979,38$ & $134.847,22$ & $18.140 .843,99$ & $100.877,19$ & $24.202 .819,62$ \\
\hline São Rafael & 098 & 1620 & $364.491,81$ & $63.949 .500,09$ & $755.796,36$ & $116.461 .134,04$ & $227.866,82$ & $45.114 .639,18$ & $179.796,29$ & $24.187 .791,99$ & $132.743,49$ & $31.848 .299,20$ \\
\hline São Vicente & 88 & 1218 & $273.593,86$ & $3.001 .600,06$ & $568.200,57$ & $87.554 .381,83$ & $170.900,12$ & $33.835 .979,38$ & $134.847,22$ & $18.140 .843,99$ & $99.795,30$ & $23.943 .250,87$ \\
\hline Senador Eói de Souza & 5.729 & 1146 & $257.394,22$ & $45.159 .400,06$ & $534.694,66$ & $82.391 .434,54$ & $170.900,12$ & $33.835 .979,38$ & $134.847,22$ & $18.140 .843,99$ & $93.910,53$ & $22.531 .354,18$ \\
\hline $\begin{array}{c}\text { Senador Georgino } \\
\text { Avelino }\end{array}$ & 4.018 & 804 & $180.895,94$ & $31.737 .900,04$ & $375.004,91$ & $57.784 .741,49$ & $113.933,41$ & 22.557.319,59 & $89.898,14$ & 12.093.896,00 & $65.863,59$ & $15.802 .230,95$ \\
\hline Serra de São Bento & 24 & 145 & $257.394,22$ & $45.159 .400,06$ & $534.228,00$ & $82.319 .527,20$ & $170.900,12$ & $33.835 .979,38$ & $134.847,22$ & $18.140 .843,99$ & $93.828,57$ & $22.511 .689,88$ \\
\hline Serra Negra do Norte & 305 & 1561 & $50.992,12$ & $61.581 .000,08$ & $728.450,31$ & $112.247 .363,69$ & \begin{tabular}{|l}
$227.866,82$ \\
\end{tabular} & $45.114 .639,18$ & \begin{tabular}{|l}
$179.796,29$ \\
\end{tabular} & 24.187.791,99 & $127.940,60$ & $30.695 .971,26$ \\
\hline Serrinha & 480 & 1296 & $291.593,45$ & $51.159 .600,07$ & $604.786,42$ & $93.191 .917,58$ & $170.900,12$ & $33.835 .979,38$ & $134.847,22$ & $18.140 .843,99$ & $106.221,02$ & $25.484 .931,94$ \\
\hline Serrinha dos Pintos & & & $06.095,37$ & $.159 .100,05$ & $427.177,07$ & $5.823 .982,53$ & $113.933,41$ & $22.557 .319,59$ & $89.898,14$ & $12.093 .896,00$ & $75.026,79$ & $18.000 .699,61$ \\
\hline Severiano Melo & 5.848 & 1170 & $262.794,10$ & $46.106 .800,06$ & $545.801,08$ & $84.102 .829,32$ & $170.900,12$ & $33.835 .979,38$ & $134.847,22$ & $18.140 .843,99$ & $95.861,19$ & $22.999 .364,50$ \\
\hline Sítio Novo & 5.107 & 1021 & $229.494,85$ & $40.264 .500,05$ & $476.642,63$ & $73.446 .160,97$ & $113.933,41$ & $22.557 .319,59$ & $89.898,14$ & $12.093 .896,00$ & $83.714,62$ & $20.085 .115,34$ \\
\hline Taboleiro Grande & 2.361 & 472 & $106.197,61$ & $18.632 .200,03$ & $220.355,05$ & $33.954 .647,75$ & $56.966,71$ & $11.278 .659,79$ & $44.949,07$ & $6.046 .948,00$ & $38.701,83$ & $9.285 .482,15$ \\
\hline $\begin{array}{c}\text { Tenente Laurentino } \\
\text { Cruz } \\
\end{array}$ & 77 & 1111 & 38 & 06 & 51 & 91 & 00,12 & 38 & 22 & 99 & 08 & 28 \\
\hline Tibau & 3.761 & 752 & $169.196,20$ & $29.685 .200,04$ & $351.018,78$ & $54.088 .704,02$ & $113.933,41$ & $22.557 .319,59$ & $89.898,14$ & $12.093 .896,00$ & $61.650,81$ & $14.791 .485,96$ \\
\hline Timbaúba dos Batistas & 2.312 & 462 & \begin{tabular}{|l}
$104.397,66$ \\
\end{tabular} & $18.316 .400,02$ & $215.781,82$ & $33.249 .955,78$ & $56.966,71$ & $11.278 .659,79$ & $44.949,07$ & $6.046 .948,00$ & $37.898,61$ & $9.092 .772,01$ \\
\hline Triunfo Potiguar & 3.327 & 005 & $149.396,64$ & $26.211 .400,04$ & $310.513,03$ & $47.847 .146,57$ & $113.933,41$ & $22.557 .319,59$ & $89.898,14$ & $12.093 .896,00$ & $54.536,63$ & $13.084 .624,78$ \\
\hline rzea & & 54 & 594,66 & $85.600,06$ & $491.948,95$ & 1,85 & $113.933,41$ & $22.557 .319,59$ & $89.898,14$ & $12.093 .896,00$ & $86.402,93$ & $20.730 .104,36$ \\
\hline Venha-Ver & 3.882 & 76 & $174.596,08$ & $30.632 .600,04$ & $362.311,86$ & $55.828 .861,74$ & $113.933,41$ & $22.557 .319,59$ & $89.898,14$ & $12.093 .896,00$ & $63.634,26$ & $15.267 .362,00$ \\
\hline Viçosa & & & $3.798,34$ & $.947 .800,02$ & $152.409,91$ & $3.484 .938,49$ & $56.966,71$ & $11.278 .659,79$ & $44.949,07$ & $6.046 .948,00$ & $26.768,35$ & $6.422 .360,16$ \\
\hline Vila Flor & 2.924 & 585 & $131.397,05$ & $23.053 .400,03$ & $272.900,54$ & $42.051 .414,66$ & $56.966,71$ & $11.278 .659,79$ & $44.949,07$ & $6.046 .948,00$ & $47.930,60$ & $11.499 .682,25$ \\
\hline
\end{tabular}


B.9 - Consolidação dos resultados para Sergipe

\begin{tabular}{|c|c|c|c|c|c|c|c|c|c|c|c|c|}
\hline & & & \multirow{2}{*}{\multicolumn{4}{|c|}{ Solar Fotovoltaica }} & \multirow{2}{*}{\multicolumn{4}{|c|}{ Biomassa }} & \multirow{3}{*}{\multicolumn{2}{|c|}{ Eólica }} \\
\hline & & & & & & & & & & & & \\
\hline & & & \multicolumn{2}{|c|}{ Minirredes } & \multicolumn{2}{|c|}{ Sistemas isolados } & \multicolumn{2}{|c|}{ Resíduos Agrícolas } & \multicolumn{2}{|c|}{ Óleo de dendê } & & \\
\hline Município & \begin{tabular}{|c|} 
№ de \\
habitantes \\
projetados \\
$(2012)$
\end{tabular} & $\begin{array}{c}N^{\circ} \text { de } \\
\text { Famílias } \\
\text { (5 pessoas) }\end{array}$ & $\begin{array}{c}\text { Custo } \\
\text { evitado } \\
\text { (R\$) }\end{array}$ & $\begin{array}{c}\text { Custo do } \\
\text { empreendimento } \\
\text { considerando a } \\
\text { externalidade (R\$) }\end{array}$ & $\begin{array}{c}\text { Custo } \\
\text { evitado } \\
\text { (R\$) }\end{array}$ & $\begin{array}{c}\text { Custo do } \\
\text { empreendimento } \\
\text { considerando a } \\
\text { externalidade (R\$) }\end{array}$ & $\begin{array}{c}\text { Custo } \\
\text { evitado (R\$) }\end{array}$ & $\begin{array}{c}\text { Custo do } \\
\text { empreendimento } \\
\text { considerando a } \\
\text { externalidade (R\$) }\end{array}$ & $\begin{array}{c}\text { Custo } \\
\text { evitado } \\
\text { (R\$) }\end{array}$ & $\begin{array}{c}\text { Custo do } \\
\text { empreendimento } \\
\text { considerando a } \\
\text { externalidade (R\$) }\end{array}$ & $\begin{array}{c}\text { Custo } \\
\text { evitado } \\
\text { (R\$) }\end{array}$ & $\begin{array}{c}\text { Custo do } \\
\text { empreendimento } \\
\text { considerando a } \\
\text { externalidade (R\$) }\end{array}$ \\
\hline $\begin{array}{l}\text { Amparo de São } \\
\text { Francisco }\end{array}$ & 2.290 & 458 & $103.497,68$ & $18.158 .500,02$ & $213.728,53$ & $32.933 .563,47$ & $56.966,71$ & $11.278 .659,79$ & $44.949,07$ & $6.046 .948,00$ & $37.537,98$ & $9.006 .249,10$ \\
\hline Arauá & 495 & 1899 & $27.490,40$ & $75.002 .500,10$ & $36.180,10$ & $136.552 .045,90$ & $227.866,82$ & $45.114 .639,18$ & $179.796,29$ & $24.187 .791,99$ & $155.643,30$ & $37.342 .504,44$ \\
\hline Brejo Grande & 339 & 1568 & $52.792,08$ & $61.896 .800,08$ & $731.623,57$ & $112.736 .333,63$ & $227.866,82$ & $45.114 .639,18$ & $179.796,29$ & $24.187 .791,99$ & $128.497,93$ & $30.829 .688,50$ \\
\hline Canhoba & 355 & 791 & $178.196,00$ & $31.264 .200,04$ & $369.125,04$ & $56.878 .708,96$ & $113.933,41$ & $22.557 .319,59$ & $89.898,14$ & $12.093 .896,00$ & $64.830,89$ & $15.554 .460,77$ \\
\hline Cedro de São João & 5.672 & 1134 & $255.594,26$ & $44.843 .600,06$ & $529.374,78$ & $81.571 .690,82$ & $170.900,12$ & $33.835 .979,38$ & $134.847,22$ & $18.140 .843,99$ & $92.976,18$ & $22.307 .181,17$ \\
\hline Cumbe & 3.839 & 768 & $172.796,12$ & $30.316 .800,04$ & $358.298,62$ & $55.210 .458,58$ & $113.933,41$ & $22.557 .319,59$ & $89.898,14$ & $12.093 .896,00$ & $62.929,40$ & $15.098 .249,03$ \\
\hline Divina Pastora & 4.487 & 897 & $201.595,47$ & $35.369 .600,05$ & $418.777,26$ & $64.529 .650,34$ & $113.933,41$ & $22.557 .319,59$ & $89.898,14$ & 12.093.896,00 & $73.551,50$ & $17.646 .742,22$ \\
\hline Feira Nova & 363 & 1073 & $241.194,58$ & $42.317 .200,06$ & $500.535,43$ & $77.127 .816,97$ & $113.933,41$ & $22.557 .319,59$ & $89.898,14$ & $12.093 .896,00$ & $87.911,01$ & $21.091 .927,47$ \\
\hline General Maynard & 009 & 602 & $134.996,97$ & $23.685 .000,03$ & $280.833,69$ & $43.273 .839,51$ & $56.966,71$ & $11.278 .659,79$ & $44.949,07$ & $6.046 .948,00$ & $49.323,93$ & $11.833 .975,34$ \\
\hline Gracho Cardoso & 665 & 1133 & $254.694,28$ & $44.685 .700,06$ & $528.721,46$ & $81.471 .020,54$ & $170.900,12$ & $33.835 .979,38$ & $134.847,22$ & $18.140 .843,99$ & $92.861,43$ & $22.279 .651,15$ \\
\hline Iha das Flores & 599 & 1672 & $376.191,55$ & $66.002 .200,09$ & $780.155,81$ & $20.214 .697,39$ & $227.866,82$ & $45.114 .639,18$ & $179.796,29$ & $24.187 .791,99$ & $137.021,84$ & $32.874 .775,63$ \\
\hline Itabi & 942 & 988 & $222.295,01$ & $39.001 .300,05$ & $461.242,97$ & $71.073 .218,63$ & $113.933,41$ & $22.557 .319,59$ & $89.898,14$ & $12.093 .896,00$ & $81.009,92$ & $19.436 .193,46$ \\
\hline Macambira & 6.492 & 1298 & $292.493,43$ & $51.317 .500,07$ & $605.906,39$ & $93.364 .495,21$ & $170.900,12$ & $33.835 .979,38$ & $134.847,22$ & $18.140 .843,99$ & $106.417,73$ & $25.532 .126,26$ \\
\hline Malhada dos Bois & 3.494 & 699 & $157.496,46$ & $27.632 .500,04$ & $326.099,34$ & $50.248 .851,86$ & $113.933,41$ & $22.557 .319,59$ & $89.898,14$ & $12.093 .896,00$ & $57.274,11$ & $13.741 .412,38$ \\
\hline Muribeca & 7.381 & 1476 & $332.092,54$ & $58.265 .100,08$ & $688.877,86$ & $106.149 .620,94$ & $170.900,12$ & $33.835 .979,38$ & $134.847,22$ & $18.140 .843,99$ & $120.990,33$ & $29.028 .438,68$ \\
\hline $\begin{array}{l}\text { Nossa Senhora } \\
\text { Aparecida }\end{array}$ & 8.543 & 1709 & $384.291,37$ & $67.423 .300,09$ & $797.328,76$ & $122.860 .887,64$ & $227.866,82$ & $45.114 .639,18$ & $179.796,29$ & 24.187.791,99 & $140.037,99$ & $33.598 .421,84$ \\
\hline $\begin{array}{c}\text { Nossa Senhora de } \\
\text { Lourdes }\end{array}$ & 6.271 & 1254 & $282.593,65$ & $49.580 .600,07$ & $585.280,19$ & $90.186 .190,61$ & $170.900,12$ & $33.835 .979,38$ & $134.847,22$ & $18.140 .843,99$ & $102.795,07$ & $24.662 .964,23$ \\
\hline Pedra Mole & 3.026 & 605 & $135.896,95$ & $23.842 .900,03$ & $282.420,32$ & $43.518 .324,48$ & $56.966,71$ & $11.278 .659,79$ & $44.949,07$ & $6.046 .948,00$ & $49.602,59$ & $11.900 .833,96$ \\
\hline Pedrinhas & 8.970 & 1794 & $404.090,92$ & $70.897 .100,10$ & $837.181,20$ & $129.001 .774,80$ & $227.866,82$ & $45.114 .639,18$ & $179.796,29$ & $24.187 .791,99$ & $147.037,43$ & $35.277 .753,01$ \\
\hline Pinhão & 84 & 1217 & $273.593,86$ & $48.001 .600,06$ & $567.827,25$ & $87.496 .855,95$ & $170.900,12$ & $33.835 .979,38$ & $134.847,22$ & $18.140 .843,99$ & $99.729,74$ & $23.927 .519,43$ \\
\hline Pirambu & 538 & 08 & $384.291,37$ & $67.423 .300,09$ & $796.862,10$ & $122.788 .980,30$ & $227.866,82$ & $45.114 .639,18$ & $179.796,29$ & $24.187 .791,99$ & $139.956,03$ & $33.578 .757,55$ \\
\hline Riachuelo & 09 & 02 & $427.490,40$ & $75.002 .500,10$ & $887.486,73$ & $136.753 .386,47$ & $227.866,82$ & $45.114 .639,18$ & $179.796,29$ & $24.187 .791,99$ & $155.872,79$ & $37.397 .564,48$ \\
\hline Rosário do Catete & 41 & 1908 & $429.290,36$ & $75.318 .300,10$ & $890.473,33$ & $137.213 .593,47$ & $227.866,82$ & $45.114 .639,18$ & $179.796,29$ & $24.187 .791,99$ & $156.397,34$ & $37.523 .415,99$ \\
\hline Santa Rosa de Lima & 3.773 & 1 & $170.096,18$ & $29.843 .100,04$ & $352.138,76$ & $54.261 .281,64$ & $113.933,41$ & $22.557 .319,59$ & $89.898,14$ & $12.093 .896,00$ & $61.847,52$ & $14.838 .680,28$ \\
\hline $\begin{array}{c}\text { Santana do São } \\
\text { Francisco } \\
\end{array}$ & 7.175 & 1435 & $323.092,74$ & $56.686 .100,08$ & $669.651,63$ & 103.187.038,37 & $170.900,12$ & $33.835 .979,38$ & $134.847,22$ & $18.140 .843,99$ & $117.613,55$ & $28.218 .269,55$ \\
\hline São Francisco & 3.524 & 705 & $158.396,44$ & $27.790 .400,04$ & $328.899,28$ & $50.680 .295,92$ & $113.933,41$ & $22.557 .319,59$ & $89.898,14$ & $12.093 .896,00$ & $57.765,88$ & $13.859 .398,17$ \\
\hline São Miguel do Aleixo & 3.736 & 747 & $168.296,22$ & $29.527 .300,04$ & $348.685,50$ & $53.729 .167,30$ & $113.933,41$ & $22.557 .319,59$ & $89.898,14$ & $12.093 .896,00$ & $61.241,01$ & $14.693 .164,46$ \\
\hline Siriri & 8.169 & 1634 & $367.191,75$ & $64.423 .200,09$ & $762.422,88$ & $117.482 .218,32$ & $227.866,82$ & $45.114 .639,18$ & $179.796,29$ & $24.187 .791,99$ & $133.907,33$ & $32.127 .532,25$ \\
\hline Telha & 3.006 & 601 & $134.996,97$ & $23.685 .000,03$ & $280.553,70$ & $43.230 .695,10$ & $56.966,71$ & $11.278 .659,79$ & $44.949,07$ & $6.046 .948,00$ & $49.274,75$ & $11.822 .176,76$ \\
\hline
\end{tabular}


APÊNDICE C - Programação em VBA do Cálculo da Viabilidade Econômica da Energia Solar Fotovoltaica - Sistema

Isolado

Private Sub Efix_Change()

Dim Efix As Double

End Sub

Private Sub Arm_Change()

Dim Arm As Double

End Sub

Private Sub Kit_Change()

Dim Kit As Double

End Sub

Private Sub nsist_Click()

Dim nsist As Double

nsist $=\operatorname{Int}(($ np. Value $) / 5)$

MsgBox " Número de Sistemas de Energia Solar - Sistema Isolado " \& nsist \& " em " \& x \& " anos."

End Sub

Private Sub Sinst_Change()

Dim Sinst As Double

End Sub

Private Sub Vsol_Change()

Dim Vsol As Double

End Sub

Private Sub painel_Change()

Dim painel As Double 


\section{End Sub}

Private Sub contro_Change()

Dim contro As Double

End Sub

Private Sub bat_Change()

Dim bat As Double

End Sub

Private Sub cee_Change()

Dim cee As Integer

End Sub

Private Sub emiss_Change()

Dim emiss As Double

End Sub

Private Sub Vcer_Change()

Dim Vcer As Double

End Sub

Private Sub Vdolar_Change()

Dim Vdolar As Double

End Sub

Private Sub pico_Change()

Dim pico As Double

End Sub

Private Sub h_Change()

Dim h As Double

End Sub 
Private Sub Inv_Change()

Dim Inv As Double

End Sub

Private Sub np_Change()

Dim np As Integer

End Sub

Private Sub nf_Change()

Dim nf As Integer

$\mathrm{nf}=\mathrm{np} / 5$

End Sub

Private Sub fc_Change()

Dim fc As Double

End Sub

Private Sub edia_Change()

Dim edia As Double

End Sub

Private Sub CommandButton4_Click()

Dim consumo As Double

consumo $=$ pico $* \mathrm{fc} * \mathrm{~h} *$ edia $* 365 * \mathrm{x} *((\mathrm{np}$. Value $) / 5)$

MsgBox "(*) " \& consumo \& " kWh em " \& x \& " anos."

End Sub

Private Sub CommandButton7_Click()

Dim VERAT As Double

VERAT $=$ Vsol $-((($ pico $* \mathrm{fc} * \mathrm{~h} *$ edia $* 365) * \mathrm{x})) *((\mathrm{np}$. Value $) / 5) *$ emiss $*$ Vcer $*$ Vdolar

MsgBox "(*) " \& VERAT \& " R \$ em " \& x \& " anos."

End Sub

Private Sub CommandButton1_Click()

Dim valor As Double

valor $=(($ painel $* 8)+(3 * 2 *$ contro $)+(3 *$ Inv $)+($ bat $* 48))+$ Kit + Arm $+(2 *$ Efix $)+$ Sinst 
MsgBox " Custo de 1 sistema Energia Solar - Sistema Isolado " \& valor \& " moeda"

End Sub

Private Sub CommandButton3_Click()

Dim ct As Double

$\mathrm{ct}=(($ np.Value $) / 5) *((($ painel $* 8)+(3 * 2 *$ contro $)+(3 *$ Inv $)+($ bat $* 48))+\mathrm{Kit}+\mathrm{Arm}+(2 *$ Efix $)+$ Sinst $)+\mathrm{Vsol}-(((\mathrm{pico} * \mathrm{fc} * \mathrm{~h} *$ edia $* 365) * \mathrm{x})) *((\mathrm{np}$. Value $) / 5) *$ emiss * Vcer $*$ Vdolar

MsgBox " Custo total do Empreendimento da Energia Solar - Sistema Isolado " \& ct \& " moeda em" \& x \& " anos."

End Sub

Private Sub CommandButton5_Click()

Dim presolar As Double

presolar $=((($ np.Value $) / 5) *((($ painel $* 8)+(3 * 2 *$ contro $)+(3 *$ Inv $)+($ bat $* 48))+$ Kit + Arm $+(2 *$ Efix $)+$ Sinst $)+$ Vsol $-((($ pico $*$ fc $*$ $\mathrm{h} *$ edia $* 365) * \mathrm{x})) *((\mathrm{np}$. Value $) / 5) *$ emiss $*$ Vcer $*$ Vdolar $) /((\mathrm{pico} * \mathrm{fc} * \mathrm{~h} *$ edia $* 365 * \mathrm{x}) *((\mathrm{np}$. Value $) / 5))$

MsgBox " Custo da Energia Solar - Sistema Isolado " \& presolar \& " moeda/kWh"

End Sub

Private Sub ok_Click()

Dim ul As Long

ul = Worksheets("tabela").Range("A65536").End(xlUp).Row + 1

With Worksheets("tabela")

.Cells(ul, 1).Value = "CÁLCULO DA VIABILIDADE ECONOMICA DA ENERGIA SOLAR - Sistema Isolado"

.Cells(ul, 1).Interior.ColorIndex $=26$

.Cells $(\mathrm{ul}+1,1)$.Value $=$ "Consumo de Energia Elétrica kWh"

.Cells $(\mathrm{ul}+1,1)$. Interior. ColorIndex $=35$

.Cells $(u l+1,2)$. Value = "Número de pessoas"

.Cells $(u l+1,2)$.Interior.ColorIndex $=40$

.Cells $(u l+1,3)$.Value $=$ "Consumo Mensal"

.Cells $(\mathrm{ul}+1,3)$. Interior.ColorIndex $=35$

.Cells $(u l+1,4)$. Value $=$ "Consumo Anual" 
.Cells $(\mathrm{ul}+1$, 4). Interior.ColorIndex $=40$

.Cells $(\mathrm{ul}+1,3)$. Interior.ColorIndex $=35$

.Cells $(u l+1,5)$.Value $=$ "anos"

.Cells $(\mathrm{ul}+1,5)$.Interior.ColorIndex $=40$

.Cells $(\mathrm{ul}+1,6)$.Value $=$ "Consumo Previsto"

.Cells $(u l+1,6)$.Interior.ColorIndex $=35$

.Cells $(u l+2,1)$.Value $=$ np.Value

.Cells $(\mathrm{ul}+2,2)$. Value $=((($ pico $* \mathrm{fc} * \mathrm{~h} *$ edia $* 365) * \mathrm{x})) *((\mathrm{np}$. Value $) / 5)$

.Cells $(\mathrm{ul}+2,3)$. Value $=((($ pico $* \mathrm{fc} * \mathrm{~h} *$ edia $* 365) * \mathrm{x})) *((\mathrm{np}$. Value $) / 5) * 12$

.Cells $(\mathrm{ul}+2,4)$. Value $=\mathrm{x}$

.Cells $(\mathrm{ul}+2,5) \cdot$ Value $=((($ pico $* \mathrm{fc} * \mathrm{~h} *$ edia $* 365) * \mathrm{x})) *(($ np.Value $) / 5) * 12 * \mathrm{x}$

.Cells.Columns.AutoFit

End With

End Sub

Private Sub grafsolarSI_Click()

Dim ul As Long

ul = Worksheets("grafsolarSI").Range("A65536").End(xlUp).Row + 1

With Worksheets("grafsolarSI")

.Cells(ul, 1).Value $=$ np. Value

. Cells $($ ul, 2). Value $=(($ np.Value $) / 5) *((($ painel $* 8)+(3 * 2 *$ contro $)+(3 *$ Inv $)+($ bat $* 48))+$ Kit + Arm $+(2 *$ Efix $)+$ Sinst $)+$ Vsol $((($ pico $* \mathrm{fc} * \mathrm{~h} *$ edia $* 365) * \mathrm{x})) *((\mathrm{np}$. Value $) / 5) *$ emiss $*$ Vcer $*$ Vdolar

.Cells $($ ul, 3) $)$ Value $=(($ painel $* 8)+(3 * 2 *$ contro $)+(3 *$ Inv $)+($ bat $* 48))+$ Kit + Arm $+(2 *$ Efix $)+$ Sinst

.Cells $($ ul, 4). Value $=((($ np.Value $) / 5) *((($ painel $* 8)+(3 * 2 *$ contro $)+(3 *$ Inv $)+($ bat $* 48))+$ Kit + Arm $+(2 *$ Efix $)+$ Sinst $)+$ Vsol $((($ pico $* \mathrm{fc} * \mathrm{~h} *$ edia $* 365) * \mathrm{x})) *((\mathrm{np}$. Value $) / 5) *$ emiss $*$ Veer $*$ Vdolar $) /(($ pico $* \mathrm{fc} * \mathrm{~h} *$ edia $* 365 * \mathrm{x}) *((\mathrm{np}$. Value $) / 5))$

.Cells.Columns.AutoFit

End With

End Sub

Private Sub pee_Click()

Dim pee As Double

Dim peeano As Double

Dim peetotal As Double 
Dim mwh As Double

pee $=$ pico $*$ fc $*$ h $*$ edia

peeano $=$ pee $* 365$

peetotal $=$ peeano $* \mathrm{x}$

mwh $=$ peetotal $/ 1000$

MsgBox "A energia útil produzida em um dia é: " \& pee \& " kWh"

MsgBox "A energia útil produzida em um ano é: " \& peeano \& " kWh"

MsgBox "A energia útil total produzida em " \& x \& " anos é: " \& peetotal \& " kWh"

MsgBox " A enegia útil total produzida por 1 sistema é: " \& mwh \& " MWh"

End Sub

\section{Private Sub tabela_Click()}

Dim ul As Long

ul = Worksheets("tabela").Range("A65536").End(xlUp).Row + 1

With Worksheets("tabela")

.Cells $($ ul $+1,1)$.Value $=$ "pico"

.Cells $(\mathrm{ul}+1,1)$.Interior.ColorIndex $=35$

.Cells $(u l+1,2) \cdot$ Value $=$ "insolação média"

.Cells $(\mathrm{ul}+1,2)$. Interior.ColorIndex $=40$

.Cells $(\mathrm{ul}+1,3)$. Value $=$ "fator de capacidade solar"

.Cells $(\mathrm{ul}+1,3)$. Interior.ColorIndex $=35$

.Cells $(u l+2,1) \cdot$ Value $=$ pico

.Cells $(\mathrm{ul}+2,2) \cdot$ Value $=\mathrm{h}$. Value

.Cells $(\mathrm{ul}+2,3) \cdot$ Value $=\mathrm{fc}$ 
Cells $(\mathrm{ul}+3,1)$. Value $=$ "Energia Produzida em 1 dia $(\mathrm{kWh}) "$

Cells $(\mathrm{ul}+3,1)$.Interior.ColorIndex $=35$

Cells $(\mathrm{ul}+3,2)$. Value $=$ pico $* \mathrm{fc} * \mathrm{~h} *$ edia

Cells $(\mathrm{ul}+4,1) \cdot$ Value $=$ "Energia Produzida em 1 ano $(\mathrm{kWh}) "$

.Cells $(\mathrm{ul}+4,1)$.Interior.ColorIndex $=35$

Cells $(\mathrm{ul}+4,2) \cdot$ Value $=$ pico $* \mathrm{fc} * \mathrm{~h} *$ edia $* 365$

Cells $(\mathrm{ul}+5,1) \cdot$ Value $=$ "Energia Produzida em " \& x \& " anos (kWh)"

Cells $(\mathrm{ul}+5,1)$.Interior.ColorIndex $=35$

Cells $(\mathrm{ul}+5,2) \cdot$ Value $=($ pico $* \mathrm{fc} * \mathrm{~h} *$ edia $* 365) * \mathrm{x}$

Cells $(\mathrm{ul}+6,1) \cdot$ Value $=$ "Energia Produzida em MWh"

.Cells $(\mathrm{ul}+6,1)$.Interior.ColorIndex $=35$

Cells $(\mathrm{ul}+6,2) \cdot$ Value $=(($ pico $* \mathrm{fc} * \mathrm{~h} *$ edia $* 365) * \mathrm{x}) / 1000$

Cells $(\mathrm{ul}+7,1) \cdot$ Value $=$ "Número de Sistemas"

Cells $(\mathrm{ul}+7,1)$. Interior.ColorIndex $=35$

Cells $(u l+7,2)$. Value $=(($ np.Value $) / 5)$

.Cells $(u l+8,1)$. Value $=$ "Custo Total de 1 sistema em " \& x \& " anos (moeda)"

Cells $(\mathrm{ul}+8,1)$. Interior.ColorIndex $=35$

Cells $(\mathrm{ul}+8,2)$. Value $=(($ painel $* 8)+(3 * 2 *$ contro $)+(3 *$ Inv $)+($ bat $* 48))+$ Kit + Arm $+(2 *$ Efix $)+$ Sinst

Cells $(\mathrm{ul}+9,1) \cdot$ Value $=$ "Custo do emprendimento em " \& x \& " anos (moeda)"

Cells $(\mathrm{ul}+9,1)$. Interior.ColorIndex $=35$

Cells $($ ul $+9,2) \cdot$ Value $=(($ np.Value $) / 5) *((($ painel $* 8)+(3 * 2 *$ contro $)+(3 *$ Inv $)+($ bat $* 48))+$ Kit + Arm $+(2 *$ Efix $)+$ Sinst $)+$ Vsol $((($ pico $* \mathrm{fc} * \mathrm{~h} *$ edia $* 365) * \mathrm{x})) *((\mathrm{np}$. Value $) / 5) *$ emiss $*$ Vcer $*$ Vdolar

Cells $(\mathrm{ul}+10,1)$. Value $=$ " Custo da Energia Solar - Sistema Isolado (moeda/kWh) $"$

Cells $(\mathrm{ul}+10,1) \cdot$.Interior. ColorIndex $=35$

Cells $(\mathrm{ul}+10,2)$. Value $=(((\mathrm{np}$. Value $) / 5) *((($ painel $* 8)+(3 * 2 *$ contro $)+(3 *$ Inv $)+($ bat $* 48))+\mathrm{Kit}+\mathrm{Arm}+(2 *$ Efix $)+$ Sinst $)+\mathrm{Vsol}$ $-(((\mathrm{pico} * \mathrm{fc} * \mathrm{~h} *$ edia $* 365) * \mathrm{x})) *((\mathrm{np}$. Value $) / 5) *$ emiss $*$ Vcer $*$ Vdolar $) /(((\mathrm{pico} * \mathrm{fc} * \mathrm{~h} *$ edia $* 365) * \mathrm{x})) *((\mathrm{np}$. Value $) / 5)$ 
.Cells.Columns.AutoFit

End With

End Sub

Private Sub UserForm_initialize()

cee.AddItem "80"

np.AddItem "1000"

np.AddItem "10000"

pico.AddItem "1,12"

pico.AddItem "1,0"

h.AddItem "5,9"

h.AddItem "1,0"

fc.AddItem "0,75"

fc.AddItem "1,0"

edia.AddItem "1,0"

painel.AddItem "900,00"

contro.AddItem "530,48"

Inv.AddItem "3237,63"

bat.AddItem "757,00"

Kit.AddItem "1632,26"

Arm.AddItem "1020,43"

Efix.AddItem "2651,61"

Sinst.AddItem "7986,32"

emiss.AddItem "0,000755"

Vcer.AddItem "5,00"

Vdolar.AddItem "2,2779"

Vsol.AddItem "0,0"

End Sub 
ANEXO A - MAPAS SOLARIMÉTRICOS

A.1 - Média anual do total diário de irradiação solar global incidente no território brasileiro

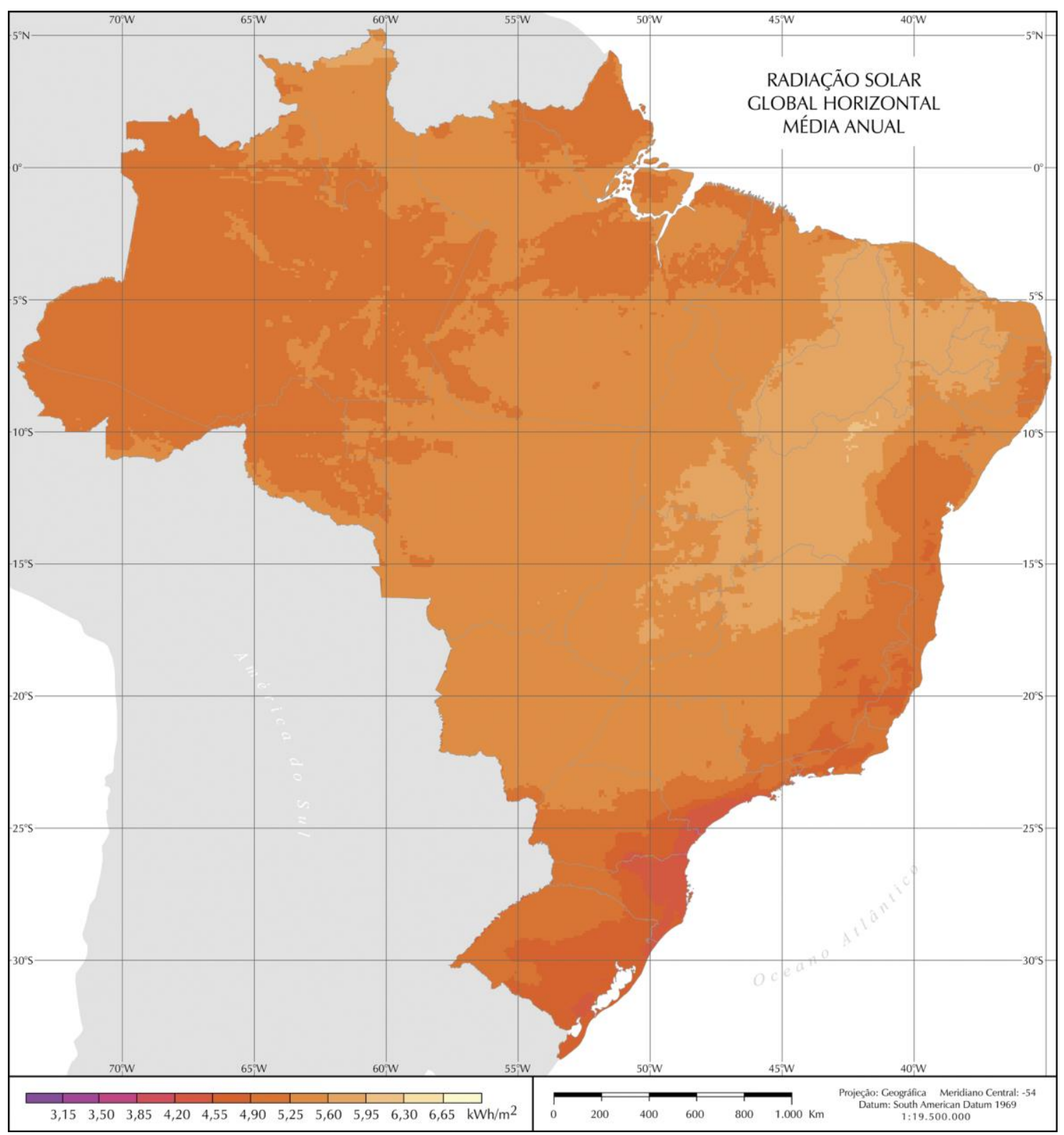

Fonte: Pereira et al., 2006. 
A.2 - Médias sazonais da irradiação global diária no território brasileiro

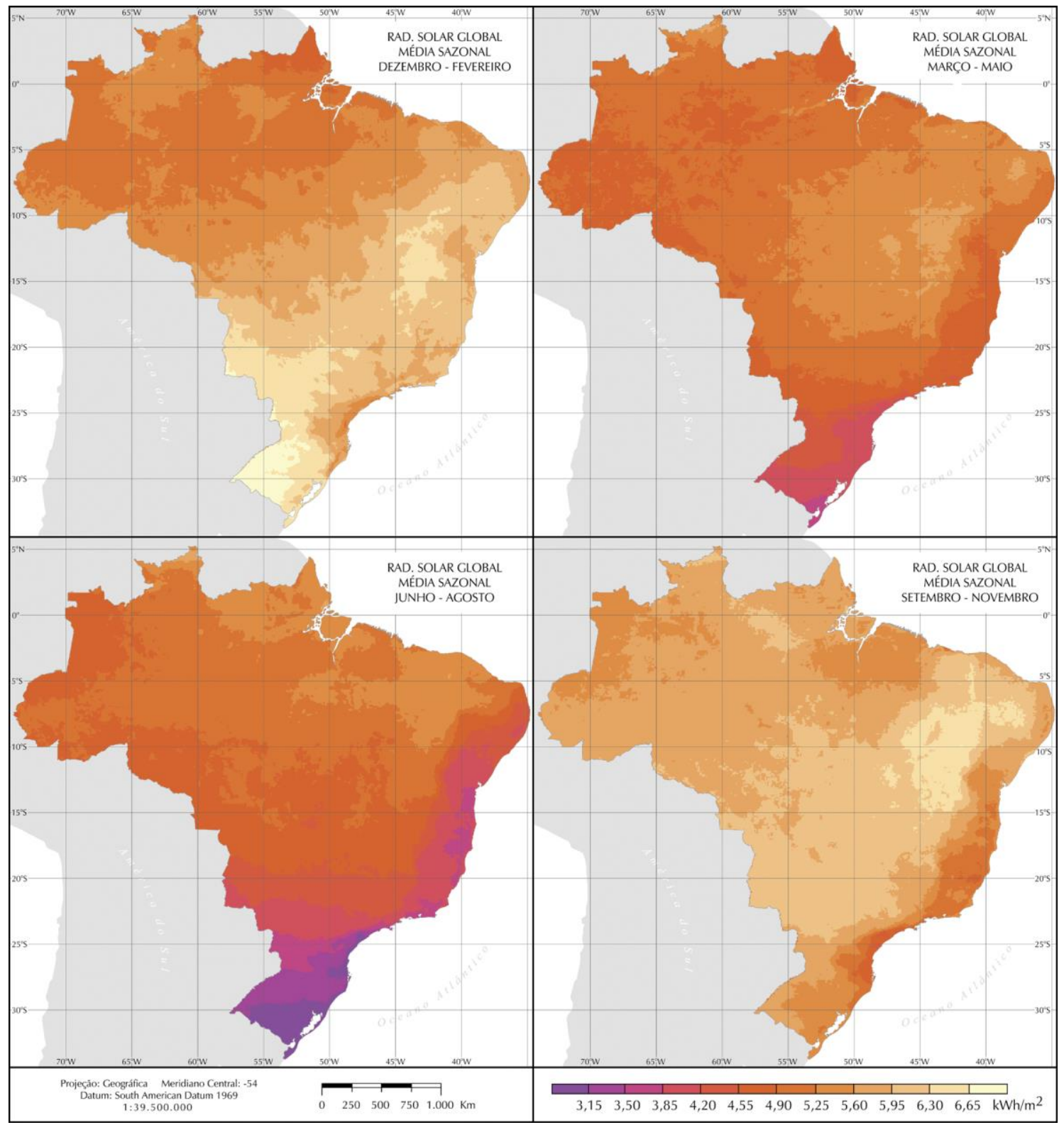

Fonte: Pereira et al., 2006. 


\section{ANEXO B - MAPAS DO POTENCIAL DE GERAÇÃO DE ENERGIA DA BIOMASSA (RESÍDUOS AGRÍCOLAS E ÓLEO DE DENDÊ) NA REGIÃO NORDESTE BRASILEIRA}

B.1 - Potencial de geração de energia a partir de resíduos agrícolas no Nordeste do Brasil

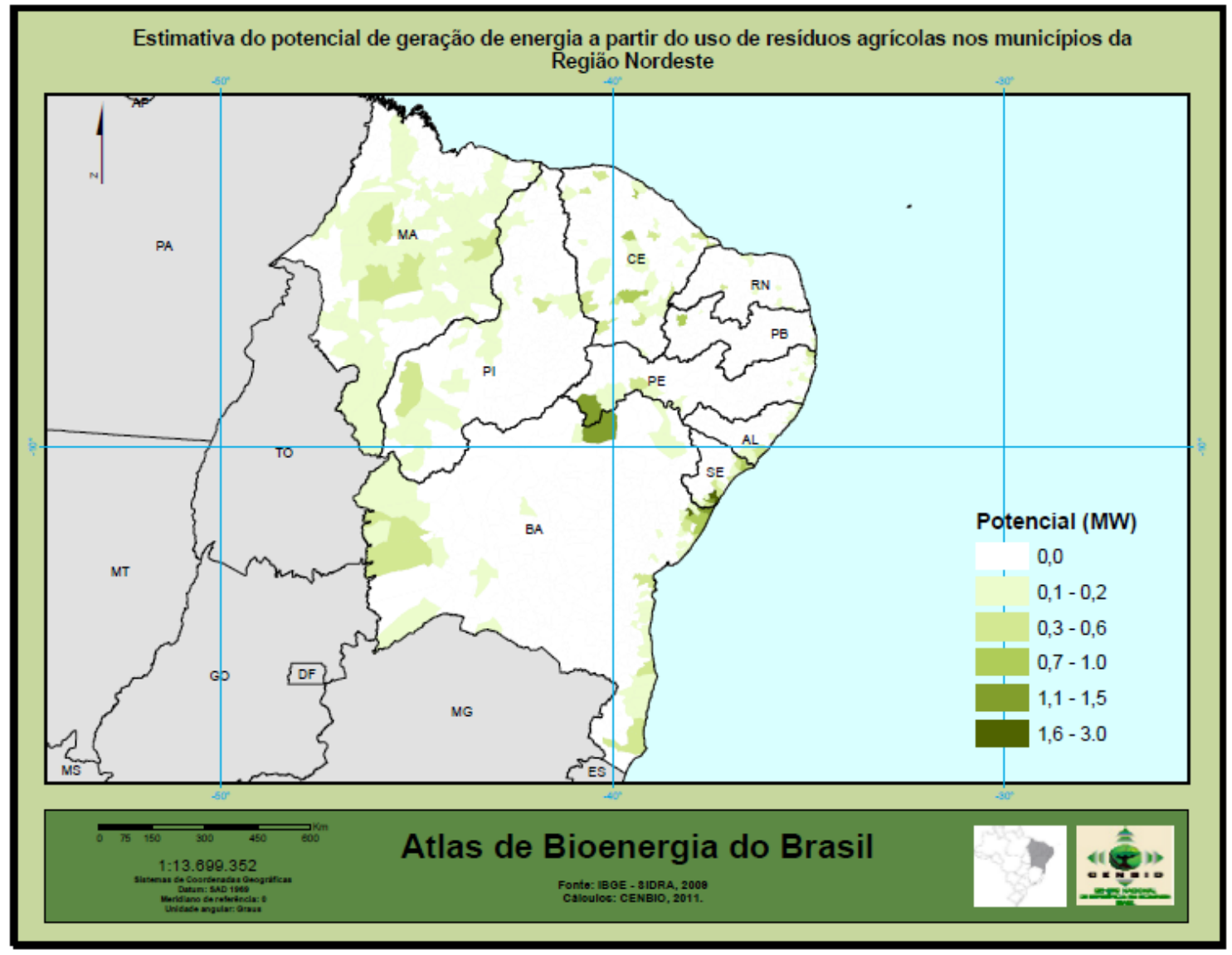

Fonte: CENBIO, 2012. 
B.2 - Potencial de geração de energia a partir da biomassa do óleo de dendê no Nordeste do Brasil

Estimativa do potencial de geração de energia a partir do uso de óleo de dendê nos municípios da Região Nordeste.
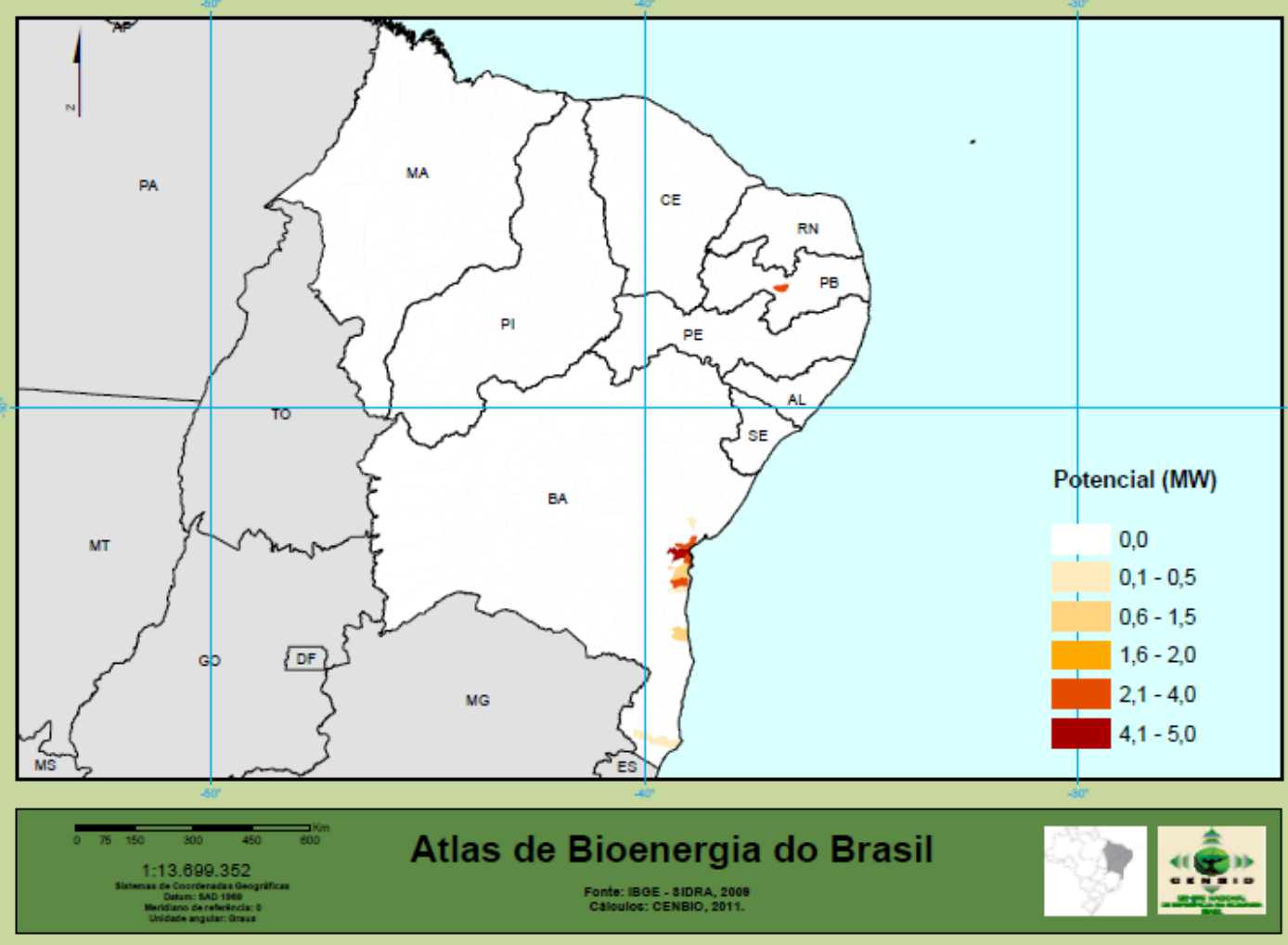

Fonte: CENBIO, 2012. 


\section{ANEXO C - MAPAS DO POTENCIAL EÓLICO BRASILEIRO}

C.1 - Velocidade média anual do vento a 50 metros de altura em $\mathrm{m} / \mathrm{s}$

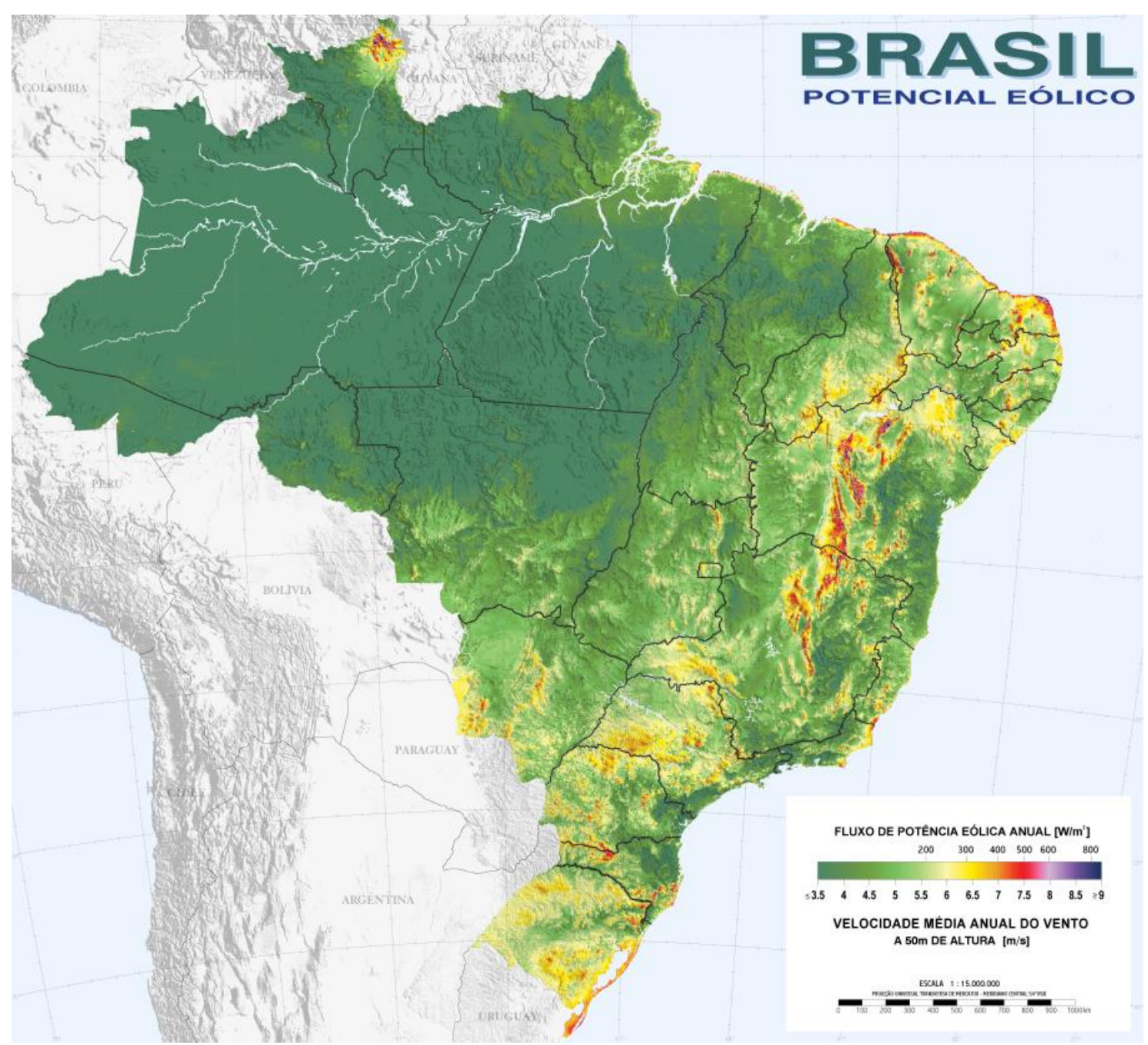

Fonte: AMARANTE et al., 2001. 
C.2 - Velocidade média anual de vento a 50 metros de altura no Nordeste do Brasil

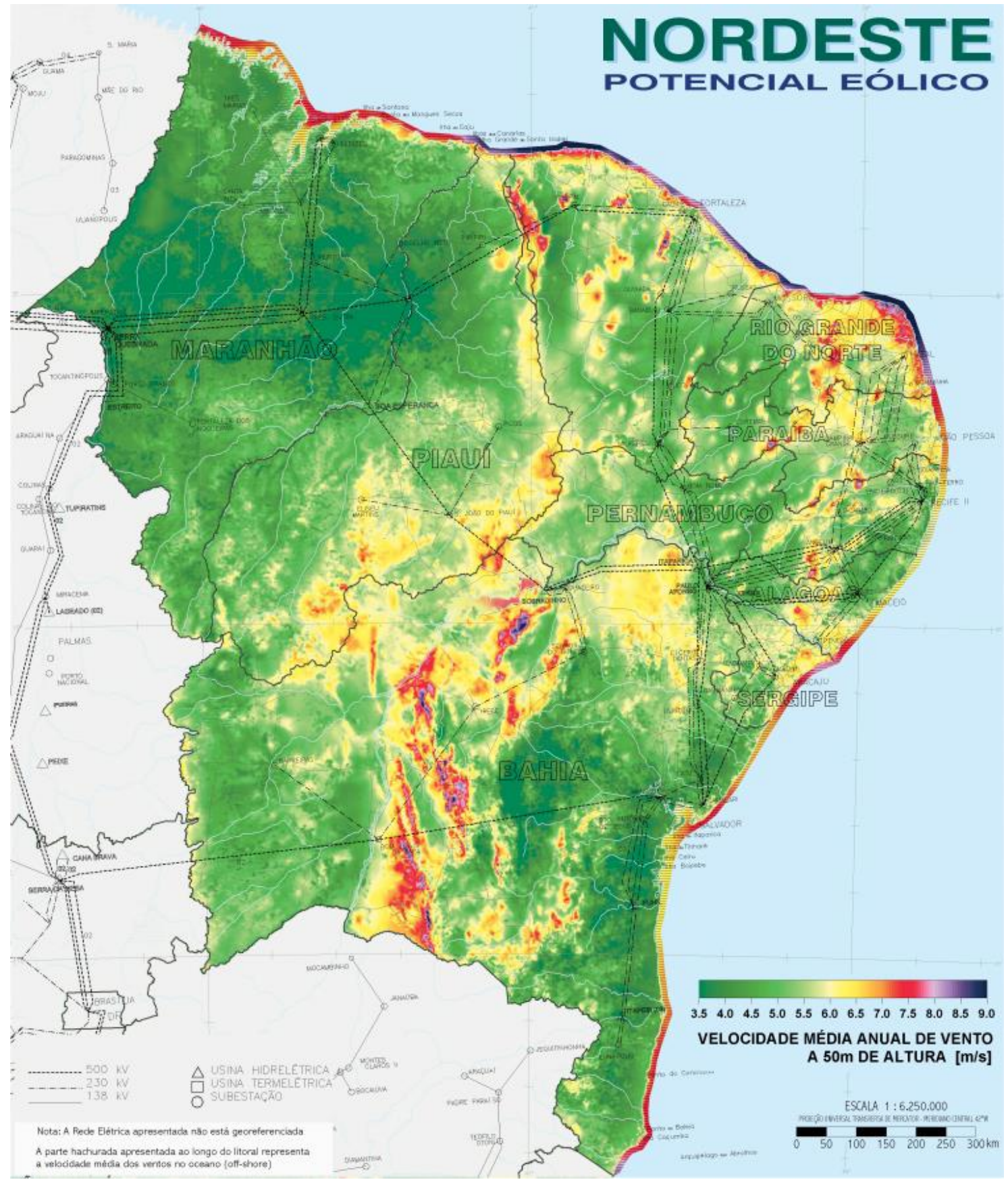

Fonte: AMARANTE et al., 2001. 


\section{REFERÊNCIAS BIBLIOGRÁFICAS}

AGÊNCIA NACIONAL DE ENERGIA ELÉTRICA - ANEEL. Atlas de energia elétrica do Brasil. Agência Nacional de Energia Elétrica. 3 ed. Brasília : Aneel, 2008.

AGÊNCIA NACIONAL DE ENERGIA ELÉTRICA - ANEEL. Estudo de vida útil econômica e taxa de depreciação. vol. 1. Escola Federal de Engenharia de Itajubá, Centro de Estudos em Recursos Naturais e Energia. ANEEL: nov. 2000.

AGÊNCIA NACIONAL DE ENERGIA ELÉTRICA - ANEEL. Resolução Normativa $n^{\circ} 83$ de 20 de setembro de 2004.

AGÊNCIA NACIONAL DE ENERGIA ELÉTRICA - ANEEL. Resolução Normativa $n^{\circ} 493$ de 5 de junho de 2012.

ALVIM, C. F., FERREIRA, O. C., GUIDICINI, O. M., EILDELMAN, F., FERREIRA, P. A., BERNARDES, M. A. S. Comparação da emissão de gases de efeito estufa (GEE) na geração nuclear de eletricidade no Brasil com a de outras fontes.

Economia \& Energia, n. 79, out/dez de 2010.

AMARANTE, O. A. C.; BROWER, M.; ZACK, J.; SÁ, A. L. Atlas do potencial eólico brasileiro. Camargo Schubert Engenharia Eólica, True Wind Solutions, CRESESB, CEPEL, Eletrobrás, Ministério de Minas e Energia, Governo Federal. Brasília, 2001.

BANCO CENTRAL DO BRASIL. Boletim regional do Banco Central do Brasil. Jan 2009, vol. 3, n. 1. Disponível em:

http://www.bcb.gov.br/pec/boletimregional/port/2009/01/br200901P.pdf

Acesso em mar. 2013.

BANCO CENTRAL DO BRASIL. Calculadora do Cidadão. Disponível em:

https://www3.bcb.gov.br/CALCIDADAO/publico/exibirFormCorrecaoValores.do?m ethod=exibirFormCorrecaoValores Acesso em: set. 2013 (a).

BANCO CENTRAL DO BRASIL. Glossário. Disponível em:

http://www.bcb.gov.br/glossario.asp?Definicao=1000\&idioma=P\&idpai=GLOSSAR IO Acesso em: set. 2013 (b).

BARRETO, E. J. F. (Coord. Geral) Sistemas Híbridos: Soluções energéticas para a Amazônia. Brasília: Ministério de Minas e Energia, 2008.

BLASQUES, L. C. M.; TUPIASSU, A. F.; PINHO, J. T. Análise econômica de tecnologias para eletrificação de uma pequena comunidade isolada da Amazônia. In: XVIII SEMINÁRIO NACIONAL DE PRODUÇÃO E TRANSMISSÃO DE ENERGIA ELÉTRICA, XVIII SNPTEE, Curitiba, Paraná, Brasil, 16 a 21 de outubro de 2005. 
BRANDLI, E. N.; PANDOLFO, A.; BECKER, A. C.; KUREK, J.; BRANDLI, G. L. Análise das vantagens e limitações dos métodos de valoração de recursos ambientais: Método do custo de viagem, método de valoração contingente e método de preços hedônicos. In: XIII SIMPÓSIO DE ENGENHARIA DE PRODUÇÃO, SIMPEP, Bauru, SP, Brasil, 06 a 08 de novembro de 2006.

CENTRO DE REFERÊNCIA PARA ENERGIA SOLAR E EÓLICA SERGIO DE SALVO BRITO (CRESESB). Tutorial de energia eólica. Disponível em: http://www.cresesb.cepel.br/content.php?cid=tutorial eolica Acesso em: jul. 2013.

CENTRO NACIONAL DE REFERÊNCIA EM BIOMASSA (CENBIO). Atlas de Biomassa. Disponível em: http://cenbio.iee.usp.br/atlasbiomassa.htm Acesso em dez. 2012.

COASE, R.H. The problem of social cost. The Journal of Law and Economics. The University of Chicago Press, out. 1960, vol. 3, pp. 1-44.

COELHO, S. T.; MONTEIRO, M. B.; KARNIOL, M. R. Atlas de Bioenergia do Brasil. São Paulo, Centro Nacional de Referência em Biomassa- CENBIO, Projeto Fortalecimento Institucional do CENBIO, Convênio 721606/2009, Ministério de Minas e Energia, 2012.

COELHO, S. T.; SILVA, O. C.; VELASQUEZ, S. M. S. G.; LISBOA, A. F. A. R.; GODOY, F. Uso de óleo de palma "in natura" como combustível em comunidades isoladas da Amazônia. In: III WORKSHOP BRASIL-JAPÃO EM ENERGIA, MEIO AMBIENTE E DESENVOLVIMENTO SUSTENTÁVEL. Campinas, SP, Brasil, 23 a 25 nov. 2005.

COSTA, S. S. T. Introdução à economia do meio ambiente. Análise: Revista Cientifica de Administração, Contabilidade e Economia. Porto Alegre: v. 16, n. 2, p. 301-323, ago./dez. 2005.

DANTAS FILHO, P. L.; FRANCO, E. G.; PARENTE, V. Análise da viabilidade econômica financeira de um projeto de cogeração de energia através do bagaço de cana-de-açúcar. In: III INTERNATIONAL CONGRESS UNIVERSITYINDUSTRY COOPERATION, UNINDU, 7-10 dez. 2008, Ubatuba, Brasil.

DUTRA, R. M.; TOLMASQUIM, M. T. Estudo de viabilidade econômica para projetos eólicos com base no novo contexto do setor elétrico. Revista Brasileira de Energia, vol. 9, n. 1. Sociedade Brasileira de Planejamento Energértico, SBPE, 2002.

ELETROBRAS. Programas: PROINFRA. Disponível em: http://www.eletrobras.com/elb/Proinfa/data/Pages/LUMISABB61D26PTBRIE.htm Acesso em: fev. 2014.

EMPRESA DE PESQUISA ENERGÉTICA (EPE). Balanço Energético Nacional 2012: Ano base 2011. Rio de Janeiro: EPE, 2012 (a). 
EMPRESA DE PESQUISA ENERGÉTICA (EPE). Balanço Energético Nacional 2012 - Ano base 2011: Síntese do Relatório Final. Rio de Janeiro: EPE, 2012 (b).

ENERGIA PURA. Disponível em: https://www.energiapura.com/ Acesso em: set. 2013.

FOLHA DE SÃO PAULO. Nível de gás carbônico no ar atinge marca histórica. Ambiente, 10 mai. 2013. Disponível em: http://www1.folha.uol.com.br/ambiente/2013/05/1276619-nivel-de-gas-carbonicono-ar-passa-marca-historica.shtml Acesso em: set. 2013.

FRANCO, E. G.; DANTAS FILHO, P. L.; BURANI, G. F.; RIBEIRO, C. E. R.; TAIOLI, F. Viabilidade econômica prévia do uso de uma rede de células a combustível de hidrogênio em uma comunidade remota. III INTERNATIONAL CONGRESS UNIVERSITY-INDUSTRY Cooperation,UNINDU, 7-10 dez. 2008, Ubatuba, Brasil.

GOLDEMBERG, J. O. Energia e Meio Ambiente no Brasil. Estudos Avançados v21 n.59. São Paulo, jan/abr 2007.

HINRICHS, R. A.; KLEINBACH, M. Energia e meio ambiente. Tradução da 3o ed. Norte Americana. Tradução técnica por Flavio Maron Vichi e Leonardo Freire de Mello. São Paulo: Pioneira Thomson Learning, 2003. Título original: Energy: its use and the environment.

INSTITUTO BRASILEIRO DE GEOGRAFIA E ESTATÍSTICA (IBGE). Disponível em: http://www.ibge.gov.br/home/default.php Acesso em 03 abr. 2013.

INSTITUTO DE PESQUISA ECONÔMICA APLICADA (IPEA). Comunicados do IPEA n. 80. Utilização do mecanismo de desenvolvimento limpo.

Sustentabilidade ambiental no Brasil: biodiversidade, economia e bem-estar humano. Série eixos do desenvolvimento brasileiro, 23 fev. 2011.

KYOCERA SOLAR DO BRASIL. Disponível em:

http://www.kyocerasolar.com.br/site/index.php Acesso em 05 dez. 2012.

MANKIW, N. G. Introdução à Economia. Tradução da 5o ed. Norte-americana. Tradução por Allan Vidigal Hastings e Elisete Paes e Lima. Revisão técnica por Carlos Roberto Martins Passos e Manuel José Nunes Pinto. São Paulo, Cengage Learning, 2011. Título original: Principles of Economics.

MASSAMBANI, O. Aquecimento Global: expectativas para o século XXI. In MENEZES, L. C. (Org.) A terra gasta: a questão do meio ambiente. São Paulo, EDUC, 1992, pp. 41-48.

MATTOS, K. M. da C.; MATTOS, A. Valoração econômica do Meio Ambiente: uma abordagem teórica e prática. São Carlos: RiMa Editora, FAPESP, 2004. 
MF RURAL. Disponivel em:

http://comprar-vender.mfrural.com.br/detalhe/grupo-gerador-de-energia-100-105110-115-125-kva-silenciado-motor-cummins-123374.aspx Acesso em 06 ago. 2013.

MELO, J. R.; MEDEIROS, J. F.; MARQUES, R. G.; ANDRADE, A. A. Estudo das características do licor negro. Revista de engenharia e tecnologia, vol. 3, n. 1, 2011.

MORET, A. S. Desafios ao setor elétrico de Rondônia, como a biomassa sustentável pode contribuir para o aumento da oferta de eletricidade: o caso dos resíduos agrícolas. In: IV CONGRESSO BRASILEIRO DE PLANEJAMENTO ENERGÉTICO, CBPE 2004, Itajubá, Brasil, 2004.

MOTTA, R. S. Manual para Valoração Econômica de Recursos Ambientais. Brasília: Ministério do Meio Ambiente, dos Recursos Hídricos e da Amazônia Legal, IPEA/MMA/PNUD/CNPq, 1998.

MOTTA, R. S.; MENDES, A. P. F. Custos de saúde associados à poluição do ar no Brasil. Pesquisa e Planejamento Econômico, vol. 25, n. 1, abr. 1995.

MOURAD, A. L.; AMBROGI, V. S.; GUERRA, S. M. G. Potencial de utilização energética da biomassa residual de grãos. In 5을 ENCONTRO DE ENERGIA NO MEIO RURAL, 2004, Campinas, SP, Brasil.

NEOSOLAR Energia. Sistemas de energia solar fotovoltaica e seus componentes. Disponível em: http://www.neosolar.com.br/aprenda/saibamais/sistemas-de-energia-solar-fotovoltaica-e-seus-componentes Acesso em set. 2013.

PEARCE, D.; MARKANDYA, A.; BARBIER, E. B. Valuing the environment. In Blueprint for a green economy. Londres: Earthscan Publication, 1991, cap. 3, pp. 51-81.

PEREIRA, E. B.; MARTINS, F. R.; ABREU, S. L.; RUTHER, R. Atlas brasileiro de energia solar. São José dos Campos: INPE, 2006.

PIGOU, A. C. The Economics of Welfare. Macmillian and Co. Limited, Londres, 1920.

PINTO, L. R. M. Análise da viabilidade da geração de energia elétrica descentralizada a partir de resíduos agrícolas no estado de Goiás e estudo de caso do município de Rio Verde. 2008. Dissertação (Mestrado), Universidade Federal de Itajubá, Itajubá.

PROGRAMA DAS NAÇÕES UNIDAS PARA O DESENVOLVIMENTO (PNUD). Ranking IDHM Unidades da Federação 2010. Disponível em: http://www.pnud.org.br/atlas/ranking/Ranking-IDHM-Municipios-2010.aspx Acesso em fev. 2014. 
PROGRAMA DE INCENTIVO ÀS FONTES ALTERNATIVAS DE ENERGIA PROINFA. Coordenação Geral de Fontes Alternativas de Energia do Ministério de Minas e Energia. Disponível em: http://www.mme.gov.br/programas/proinfa/ Acesso em: junho de 2012.

REIS, M., M. Custos Ambientais Associados à Geração Elétrica: Hidrelétricas X Termelétricas a Gás Natural. 2001. Dissertação (Mestrado). Universidade Federal do Rio de Janeiro, Rio de Janeiro.

REIS, L. B. dos; CARVALHO, C. E.; GALVÃO, L. C. R.; UDAETA, M. E. M. Inserção das externalidades no planejamento energético através do ACV e o ACC. Sociedade Brasileira de Planejamento Energético, Revista Brasileira de Energia, vol. 8, n. 2, 2001.

REIS, L.B.; GRIMONI, J. A. B.; CARVALHO, C. E.; BARCAUI, A. B.; FURTADO, J. S.; FERRAZ, M. P. R. P.; CRISTIANO, M. J. Desenvolvimento de sistema para mensuração das externalidades de projetos de linhas de transmissão. XVIII SNPTEE, SEMINÁRIO NACIONAL DE PRODUÇÃO E TRANSMISSÃO DE ENERGIA ELÉTRICA. GIA - 02. Curitiba, Paraná, 16 a 21 de out. 2005.

RODRIGUES, W. Valoração econômica dos impactos ambientais de tecnologias de plantio em região de Cerrado. Revista Economia e Sociologia Rural vol.43 n.1 Brasília Jan/Mar. 2005.

SHAYANI, R. A.; OLIVEIRA, M. A. G., CAMARGO, I.M.T. Comparação do custo entre energia solar fotovoltaica e fontes convencionais. In: V CONGRESSO BRASILEIRO DE PLANEJAMENTO ENERGÉTICO: POLÍTICAS PÚBLICAS PARA ENERGIA DESAFIOS PARA O PRÓXIMO QUADRIÊNIO - V CBPE, 31 mai. a 02 jun. 2006, Brasília, DF.

SILVA, O. C.; STELLA, O.; VARKULYA JR, A.; COELHO, S. T. Potencial de mitigação de gases estufa pela indústria de óleo de palma visando a captação de recursos do mecanismo de desenvolvimento limpo (MDL). In $3^{\circ}$ ENCONTRO DE ENERGIA NO MEIO RURAL, 2000, Campinas, São Paulo, Brasil.

SILVEIRA, S. J. C. Externalidades negativas: as abordagens neoclássica e institucionalista. Revista da FAE, Curitiba, v.9, n. 2, p. 39-49, jul./dez. 2006.

SOARES, G. F. W.; VIEIRA, L. S. R.; NASCIMENTO, M. V. G. Operação de um grupo gerador diesel utilizando óleo vegetal bruto como combustível. In 3. ENCONTRO DE ENERGIA NO MEIO RURAL, 2000, Campinas, SP.

SOLOMON, S., D. QIN; M. MANNING, Z. CHEN, M. MARQUIS, K.B. AVERYT, M. TIGNOR, H.L. MILLER (eds.). Climate Change 2007: The Physical Science

Basis. Contribution of Working Group I to the Fourth Assessment Report of the Intergovernmental Panel on Climate Change (IPCC), Cambridge University Press, Cambridge, United Kingdom and New York, NY, USA, 996 pp. 2007.

THOMAS, J. M.; CALLAN, S. J. Economia Ambiental: aplicações, políticas e teoria. São Paulo: Cengage Learning, 2010. 
TN SUSTENTÀVEL. Disponível em: http://www.tnsustentavel.com.br/biodiesel Acesso em: set. 2013.

UDAETA, M. E. M., BOARATI, J. H.; GALVAO, L. C. R.; BURANI, G. F. Valoração ambiental e econômica de recursos energéticos tradicionais In: CONGRESO INTERNACIONAL DE TRABAJOS COM TENSIÓN Y SEGURIDAD EM TRANSMISIÓN DE ENERGIA ELECTRICA. Buenos Aires: CIER, 2005. p.1-10.

VANNI, S. R. Estudo de Viabilidade Econômica de Fontes Alternativas de Energia de uma Comunidade Típica da Região Nordeste do Brasil. 2008. Dissertação (Mestrado). Instituto de Pesquisas Energéticas e Nucleares, IPENCNEN/SP, São Paulo.

VARIAN, H. R. Microeconomia: princípios básicos. Tradução da $7^{\circ}$ ed.. Tradução por Maria José Cyhlar Monteiro e Ricardo Doninelli. Revisão técnica por Lia Hasenclever. Rio de Janeiro: Elsevier, 2006, 10ำ reimpressão. Título original: Intermediate Microeconomics: a Modern Approach, Seventh Edition.

VITAL, M. H. F.; COSTA, F. C.; PINTO, M. A. C. Metodologias e técnicas para análise ambiental de projetos de investimento. In: BNDES Setorial. Rio de Janeiro: Banco Nacional de Desenvolvimento Econômico e Social, n. 34, p. 203238, set. 2011.

ZAMPIER, J. F.; MIRANDA, G. M. de. Levantamento das metodologias propostas para valoração econômica de bens ambientais. Revista Eletrônica Lato Senso, ano 2, n. 1, jul. 2007. ISSN 1980-6116. 